\title{
SPOLI, SEKSUALNOST IN NASILJE SKOZI NOVE MEDIJE
}

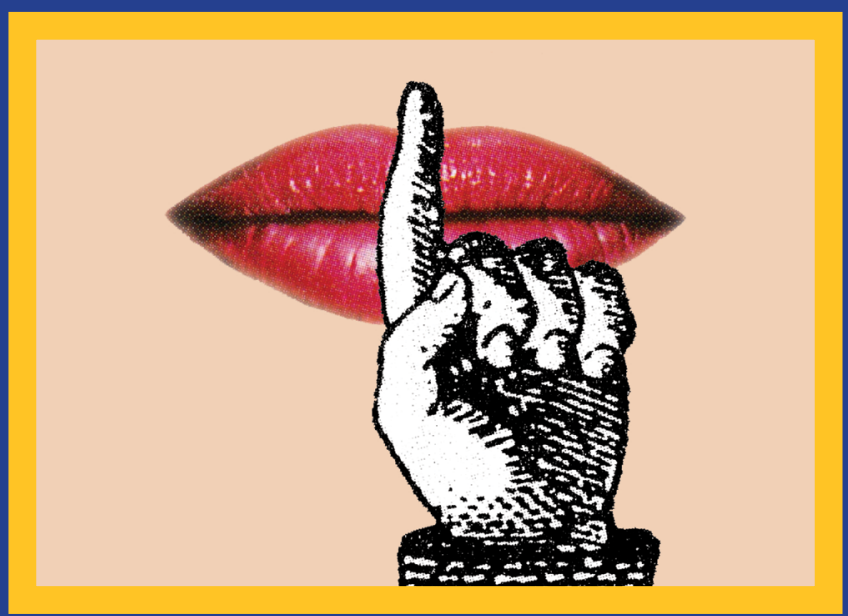



SPOLI, SEKSUALNOST IN N $\quad A \quad S \quad I \quad L \quad J \quad E$ 
aok 


\section{SPOLI, SEKSUALNOST IN NASILJE SKOZI NOVE MEDIJE}


Valerija Vendramin in Renata Šribar

Spoli, seksualnost in nasilje skozi nove medije

znanstvena monografija

Digitalna knjižnica

Uredniški odbor: Igor Ž. Žagar (Educational Research Institute \& University of Primorska), Jonatan Vinkler (University of Primorska), Janja Žmavc (Educational Research Institute),

Alenka Gril (Educational Research Institute)

Zbirka: Dissertationes (znanstvene monografije), 11

Glavni in odgovorni urednik: Igor Ž. Žagar

Urednik izdaje: Jonatan Vinkler

Recenzenta: Majda Hrženjak, Tadej Praprotnik

Lektorica: Sonja Likar

Oblikovanje, prelom in digitalizacija: Jonatan Vinkler

Motiv na naslovnici: Maja Gspan

Založnik: Pedagoški inštitut

Gerbičeva 62, SI-1000 Ljubljana

Ljubljana 2010

Za založnika: Mojca Štraus

ISBN 978-961-270-037-9 (pdf)

http://www.pei.si/ISBN/978-961-270-037-9.pdf

ISBN 978-961-270-037-9 (html)

http://www.pei.si/ISBN/978-961-270-037-9/index.html

DOl: https://www.doi.org/10.32320/978-961-270-037-9

(C) 2010 Pedagoški inštitut/Educational Research Institute

Monografija je nastala v okviru raziskovalnega projekta Epistemološki in kulturni vidiki konstrukcije spolnosti in nasilja $\checkmark$ novih informacijsko-komunikacijskih tehnologijah (IKT) ter njihovo sprejemanje pri otrocih in mladih, ki ga financira ARRS.

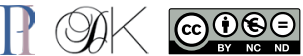

CIP - Kataložni zapis o publikaciji

Narodna in univerzitetna knjižnica, Ljubljana

$141.72(0.034 .2)$

VENDRAMIN, Valerija

Spoli, seksualnost in nasilje skozi nove medije [Elektronski vir] / Valerija Vendramin in Renata Šribar. - El. knjiga.

- Ljubljana : Pedagoški inštitut, 2010. - (Zbirka Digitalna knjižnica. Dissertationes; 11)

Način dostopa (URL): https://www.pei.si/ISBN/spoli-seksualnost-in-nasilje-skozi-nove-medije/

ISBN 978-961-270-037-9

1. Šribar, Renata

252996352 
Kazalo $\quad 7$

Predgovor 9

Uvod: soočenje z mediji in spletom pornoseksualnih in drugih konstrukcij nasilja II

Namen, teme in opredelitve študije $\quad$ I3

I Na poti k transformacijam nekaterih temeljnih epistemoloških poj$\begin{array}{ll}\text { mov skozi feministično teorijo } & \text { I7 }\end{array}$

»Utelešena znanost« in »dejstva«

Spolzki drog uporabne doktrine objektivnosti 30

Pogled od nikoder in pogled od povsod: relativizem in izkustvo $\quad 35$

(Ne)vednosti in taksonomija (ne)vednosti 39

Vrednotenja epistemologije 43

II Metodologija z etiko $\quad 45$

Metodološko orientirane in vsebinske hipoteze $\quad 47$

$\begin{array}{ll}\text { Metode } & 48\end{array}$

Konceptualni pristop $\quad 50$

Etika $\quad 54$

III Polje vzgoje in izobraževanja: identifikacija problematike in usmeritve na poti k dobrim praksam 6I

Nekaj o stanju doma in v tujini $\quad 63$

Otroštvo, mladost, seksualnost $\quad 67$

Terminoloska platforma: »spolna vzgoja《? $\quad 70$ 
Aktivnosti in nujnost refleksije na pedagoškem področju in ter načelna izhodišca ravnanja $7 \mathrm{I}$

Primer: »spolna vzgoja $\ll$ v kurikulumu 74

Uradna vednost 75

Konceptipismenosti 76

Mesto feministične teorije v edukaciji 78

Značilni primeri iz šolskega okolja 80

Simptomatični odzivi 82

IV Problematika porna in drugih konstrukcij sprege seksa in nasilja skozi nove medije 85

Opredelitev in značilnosti novih medijev 86

Koncept spolov 90

Koncept spolnosti 9I

Konceptualizacija nasilja 92 Nasilje pornoželje 94

»Tvegana razmerja «: medijske vsebine in novomedijska nadgradnja 94 Temeljne opredelitve 95

Mladostniško ospoljenje v novomedijskih razmerjih I03

»Maskulinost«, »femininost « 104

Komercialna seksualizacija 105

Razredna razmerja $v$ segmentu deklet 105

Študija primera: (samo)pornografizacija 107

Sociološki in socialnopsihološki pristop $\mathrm{k}$ potencialno škodljivim (novo)medijskim vsebinam in odnosom

V Potencialna škoda in onkraj nje v (novo)medijskih razmerjih

Platforma za izboljšanje otroških in mladostniških kompetenc na po-

dročju spolnosti, nasilja in novih medijev: »spolna vzgoja

Povzetek

Summary

Viri in literatura

Imensko kazalo 


\section{Predgovor}

S

poli, seksualnost in nasilje skozi nove medije - tema je kompleksna in podvržena zdravorazumskemu pojmovanju, ki onemogoča kritičen razmislek in utrjuje tradicionalistična pojmovanja tako v navezavi na vsebine, ki zadevajo konstrukcije spolov in spolnosti, kot družbo, kulturo in naravo. »Univerzalne « in splošno znane resnice je še posebej težko razgraditi na področjih, kjer je odsotnost ustreznih razmislekov še posebej pomembna (in pomenljiva!). Kot tako področje sva izpostavili vzgojo in izobraževanje, razmisleke pa gradiva s pomočjo epistemoloških, metodoloških in etičnih intervencij ter odpirava in teoretsko povezujeva različna aktualna polja in problematike, ki bodo prav zaradi svoje aktualnosti - v sodobnosti morda lahko ustrezno in natančno mišljena šele za nazaj. To pa ne pomeni, da jih ne moremo oz. da jih nismo zavezane misliti skozi obstoječe teoretske aparate, tokove, koncepte in kategorije. Sami sva zavezani predvsem feministični teoriji, skupaj, seveda, z njeno dediščino različnih glasov.

Ne glede na pluralnost feminističnih refleksij pa je vendarle možno opredeliti skupna mesta, navsezadnje gre praviloma prav za konceptualizacijo (ali pač dekonceptualizacijo) spolov, ki jo sami izpostavljava že v naslovu. Poleg tega skupnega tematskega izhodišča je druga raven povezovanja epistemološkega značaja; če tole zapiševa nekoliko manj ortodoksno, gre za kritičen odnos do strukturnih razmerij, ki dominantno opredeljujejo, določajo spol. Seksualnost in nasilje, kot diskurz in obenem - ali kar vključujoč - vsakdanja praksa, pa sta za vzdrževanje neenakih družbenih razmerij kar največjega pomena. Približno takšna je bila najina refleksija tudi, ko 
sva se odločili skupaj s poljem vzgoje in izobraževanja obravnavati še (nove) medije kot globalne akterje v soustvarjanju tega, čemur pravimo stvarnost.

Čeprav med številnimi tematizacijami, ki sva jih vključili v pričujoče delo, lahko navedeva tudi tvegana razmerja informacijsko-komunikacijskih tehnologij ali novih medijev z vidika potencialne škode za otroke in mladoletne (ter $s$ tem $v$ zvezi regulacijske nuje), je najina umestitev vse prej kot znotraj aktualnih raziskovalnih programov in projektov na navedenem področju.

Tveganje, vredno raziskovanja, se v monografski študiji kaže predvsem kot tveganje strukturnih diskriminacij in zlorab, kjer individualna škoda ni naključje, eksces ali znamenje premajhnega truda (šole, staršev, države). Individualna škoda kot posledica diskriminatornih pedagoških, komercialnih in novomedijskih konstrukcij spolov, spolnosti in nasilja je v najini refleksiji koncipirana kot konstitutivni element družbenega strukturiranja spolov in procesa ospoljenja v otroštvu in mladosti. Pot argumentacije pa je mnogo bolj kompleksna, kot nakazuje ta na kratko povzet uvid. Zahteva prepoznavanje kompleksnosti in ambivalenc polja, zato je tudi sama po sebi nekakšno tveganje.

Delo je nastalo v okviru projekta Epistemološki in kulturni vidiki konstrukcije spolnosti in nasilja $v$ novih informacijsko-komunikacijskih tehnologijah (IKT) ter njihovo sprejemanje pri otrocih in mladih, ki poteka pod okriljem Pedagoškega inštituta, vodi ga prvopodpisana, kot samostojna raziskovalka pa sodeluje soavtorica knjige. 


\section{Uvod: soočenje $z$ mediji in spletom pornoseksualnih in drugih konstrukcij nasilja}

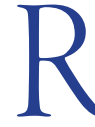

eprezentacije/konstrukcije spolov v medijih so danes izjemno konlom o »epidemičnih « razsežnostih anoreksije, tabloidna poročila o posilstvih so objavljena poleg oglasov za vroče linije ipd. Po eni strani so feministične ideje vstopile (ali pa vsaj vstopajo - vprašanje je sicer, v kakšni obliki) v sodobni zdravi razum, ${ }^{1}$ po drugi še vedno obstajajo predvidljivi vzorci seksizma (ali retroseksizma, kot je to poimenovala I. Whelehan (nav. po Gill, 2007: 1)), da nekakšne renaturalizacije spolne razlike, ki se kaže denimo v popolnoma ločenih univerzumih $\gg$ zanjo« (življenjski slog, kuhanje ...) in »zanj« (šport, politika ...) (Gill, 2007: 35), niti ne omenjava. Različna politična vprašanja, povezana $s$ feminizmom, so sedaj priznana, za nekatere so se tudi poiskale (bolj ali manj) ustrezne rešitve, kar pogosto pripelje do ugotovitve, da sodobna kultura ne potrebuje feminizma oz. da je čas za postfeminizem. ${ }^{2}$ A prav ta opustitev oz. zanikanje nujnosti ali smiselnosti feminizma omogoča subtilno oživitev spolnih neenakosti, ki jih je mogoče

\footnotetext{
${ }^{1} \mathrm{~J}$. Wicke (nav. po Gill, 2007: 40) govori o »celebrity feminism «, ki je začel »cveteti« z upadanjem ženskega gibanja in je ustoličil feministke, ki so jim naklonjeni mediji, kot sta N. Klein in C. Paglia, ki krožita po ameriških televizijskih postajah ter razpravljata o feminističnih temah (in hkrati seveda tudi promovirata svoje knjige).

${ }^{2}$ Izraz »postfeminizem « sicer označuje vsaj dve nasprotni stvari: popoln prelom s prejšnjim stanjem (torej feminizmom kot odzivom na opresivna razmerja) ali pa proces sprememb in konceptualnih premikov. A. Brooks vidi to opozicijo tudi kot opozicijo med popularno interpretacijo postfeminizma in interpretacijo feministične akademske skupnosti (Brooks, 1997: 1, in nasl.). Nasprotno pa Coppock et al. pojem razumejo zgolj v prvem pomenu, kot del »backlasha« (izraz S. Faludi) proti ženskam in feminizmu, ki se je začel uveljavljati v devetdesetih letih prejšnjega stoletja (1995: 3, in nasl.). Izraz se sicer pojavlja že v šestdesetih letih prejšnjega stoletja, kot oznaka za (domnevno) uspešen boj žensk za enakost (L. Alice, nav. po Brooks, 1997: 2).
} 
hitro spregledati, ker nad njimi visi senca nekakšnega obrazca vidnosti in očitnosti svobode, ki je sedaj povezana z kategorijo žensk/deklic (McRobbie, 2007: 720). ${ }^{3}$ Vzporedno $s$ tem gresta vse večja seksualizacija medijskih vsebin ter mainstreaming in respectabilization pornografije.

Na področju »spolov in medijev« (ali bolje: medijev in novih medijev) je za ustrezno in posodobljeno analizo treba slediti vsaj trem linijam, ki jih poskušava delno tematizirati tudi v pričujočem delu. Prvič, treba je izpostaviti sodobne reprezentacije in konstrukcije spolov v medijih in zlasti novih medijih v t. i. zahodnih ali kar globaliziranih poznokapitalističnih (oz. »visokokapitalističnih«) družbah, drugič, posvetiti se je treba teoretskim orodjem in ključnim konceptom, in tretjič, zastaviti si je treba vprašanje o tem, katere oblike politične in kulturne intervencije primerno in učinkovito spodbijajo določene konstrukcije spolov (prim. Gill, 2007: 2-3).

Obstoječa ogrodja, s pomočjo katerih ženske (lahko) spodbijajo seksizem, se včasih zreducirajo spet nazaj na določila o seksualni eksplicitno$s t i$, kar ženske potegne $\mathrm{v}$ povezovanje $s$ konzervativnimi organizacijami, $s$ katerimi sicer nimajo veliko skupnega. Poleg tega mediji z argumentom o svobodi govora trdijo, da reprezentirajo ženske tako, kot si želijo, in končna obramba je skoraj vedno: če vam ni všeč, lahko ugasnete oziroma gledate kaj drugega ipd. $\mathrm{V}$ časih vse večje deregulacije dobiva ta odgovor nov pomen - neoliberalni državljani/-ke naj se »samoregulirajo «. V primeru otrok je breme zaščite preneseno z medijev na starše (Gill, 2007: 36-37).

$\mathrm{Ob}$ tem se velja dotakniti še problematike, ki ji lahko sledimo čisto do prve faze feminizma, in to je t. i. audience studies, torej problema tega, kako sprejemniki/-ce, naslovniki/-ce sprejemajo in osmišljajo različne medijske produkte (prej: literarne produkte). Vsekakor je sedaj presežen »tekstualni determinizem «, ki je impliciral, da sprejemniki/-ce (nekritično) sprejmejo vse, kar se jim da v branje ali se jim pokaže na takem ali drugačnem zaslonu. Na tem mestu to problematiko branja/razumevanja zgolj omenjava, saj je v nadaljevanju teksta nadgrajena $\mathrm{z}$ razumevanjem uporabnice/-ka novih medijev kot aktivne/aktivnega. ${ }^{4} S$ tem v zvezi pa je nemara treba omeniti

\footnotetext{
${ }^{3}$ Sem sodi tudi uvedba kategorije »nove ženskosti« s celo vrsto specifičnih praks, ki jih razumejo hkrati kot progresivne, a tudi kot zelo in pomirjujoče ženske (McRobbie, 2007: 712, in nasl.).

${ }^{4} \mathrm{Na}$ empirični ravni se je to pokazalo tudi v segmentu otrok med pogovorom v dveh fokusnih skupinah v okviru temeljnega projekta »Epistemološki in kulturni vidiki konstrukcije spolnosti in nasilja v novih informacijsko-komunikacijskih tehnologijah (IKT) ter njihovo sprejemanje pri otrocih in mladih«. Dvanajst- do petnajstletnice/-ki so bili do vsebin oglasov za »erotiko« zadržani; vendar pa se zastavlja vprašanje, koliko se sme ta odziv razumeti kot enoznačen in ustrezen v razmerju do dejanskega odnosa pri vseh otrocih - glede na vladajočo ambivalenco do vseh konstrukcij spolnosti (ne le pornografskih). Glede konstrukcij nasilja je bila ambivalenca
} 
na neki način prelomno študijo Ch. Brunsdon in D. Morleyja o recepciji občinstva iz leta 1980 (nav. po Gill, 2007: 17, in nasl.). Zanimalo ju je, ali so različni načini interpretacije povezani z različnimi vrstami strukturne lokacije in kulturnih kompetenc (tu sta primarno izpostavila razred). Seveda so v audience studies aktualna tudi druga polja: vprašanje užitkov in uporabe medijev, ki jih tukaj prav tako samo na kratko omenjava, saj presegajo pričujočo tematizacijo reciklaže diskriminatornih spolnih tradicionalizmov skozi medije in nove medije.

\section{Namen, teme in opredelitve študije}

$S$ študijo želiva vzpostaviti notranje skladno in preverljivo spoznavno osnovo za znanstveno delo in družbeno odgovorno ravnanje na področju socializacije otrok in mladih $\mathrm{v}$ razmerjih novih medijev, s poudarkom na vlogi in statusu deklet in deklic. Delo, ki ga predstavljava, v prvi vrsti razvija konceptualno orodje, s katerim je možno preseči dominantna pojmovanja konstrukcij pornospolnosti in drugih oblik nasilja. Vključuje analitične povzetke nekaterih pristopov $\mathrm{k}$ problematiki, ki imajo aplikativni znanstveni značaj. Kljub temu, da gre v prvi vrsti za teoretski tekst, ta ne more biti povsem brez učinka na ravni vsakdanje prakse v vzgoji in izobraževanju ter pri osveščanju in opolnomočenju otrok in mladih zlasti glede novomedijskih vsebin in storitev.

Pri antropoloških, socioloških in socialnopsiholoških raziskavah, ki preučujejo potencialno škodljive vsebine medijev in novih medijev, je najpomembnejša definicija gradiva. Nasprotujoči si rezultati različnih raziskav z enako formulirano raziskovalno temo so pogosto učinek slabo opredeljenih medijev in vsebin, tega, kaj sploh se raziskuje. Empirično sociološka evidenca škode na individualni ravni je zato ambivalentna in eklektična (Zillmann in Bryant, 1989: 400). A vendar prevladujeta znanstveni in strokovni konsenz o družbeni škodi zaradi pornografske spolnosti in drugih konstrukcij spolnosti, ki vključujejo nasilje. Zaradi manka široko znanstveno, ekspertno in javno privzetih definicij, čeprav te obstajajo, je možno vednost o družbenih učinkih obravnavanih vsebin vedno znova potisniti v polje nepriznanega. Še bolj problematične v smislu pomanjkanja obče sprejetih definicij v različnih sferah določenega kulturnega okolja so konstrukcije nasilja, posebej tistega, ki se izraža na subtilnejše načine. Raziskave so precej bolj enovite v svojih rezultatih, ko gre za »tveganja« aktiv-

tudi dejansko izražena, saj je mnogo otrok ob izpričani zadržanosti do promocijskih materialov za nasilne računalniške igre naštevalo naslove prav takih iger, ki jih igrajo tudi sami. 
ne udeležbe v razmerjih novih medijev, kar pripisujeva osredinjenju tega raziskovanja v okviru velikih mednarodnih projektov, zlasti v EU.

Sami se v študiji osredotočava na obravnavo imanentno nasilne pornoseksualnosti in konstrukcij seksualiziranega nasilja ter nasilja v množičnih medijih, zlasti novih medijih; kot referenco bova v nadaljevanju navedli klasifikacijo slovenskega normativnega dokumenta, ki je bil oblikovan $\mathrm{v}$ skladu z določilom amandmiranega slovenskega zakona o medijih iz leta 2006. Vendar je ne glede na obstoj tega dokumenta splošni problem, iz katerega izhaja nuja po pričujočem tekstu, manko znanstvene refleksije in odziva na razširjajočo se kulturo pornospolnosti in nasilja ${ }^{5} \mathrm{v}$ Sloveniji v primerjavi z večino drugih držav EU. To je posledično do nedavna odsevalo $\mathrm{v}$ državnih politikah, še vedno pa je zelo opazno v mnogih, za družbeno in kulturno življenje pomembnih diskurzih, na primer v vsakdanjem izobraževalnem, medijskem in javnem. V sferi znanosti je ta zaostanek problematičen tudi zato, ker botruje humanističnemu in družboslovnemu neuvidu ali vsaj spregledu možnosti povezave med vladajočimi konstrukcijami pornoseksualnosti in empirično utelešenim nasiljem, še posebej, če je to seksualizirano ali opredeljeno kot seksualno.

Kot je razvidno, bo študija skušala pokazati na praznine, ki se kažejo na različnih ravneh spoznavanja sodobne novomedijske kulture iz perspektive socializacije in recikliranja spolno diskriminatornih razmerij. $\mathrm{Na}$ teoretski ravni bova oblikovali niz konceptov, s pomočjo katerih bo sploh mogoče misliti različne pojavnosti konstrukcij spolnosti in nasilja na sodoben in občutljiv način, usklajen z načeli človekovih pravic. Šele na tej osnovi je možno oblikovati raziskovalni aparat za ustrezno analizo lokalne kulture pornospolnosti in nasilja, za njeno obrazložitev v okviru širših sodobnih pojavov in umestitev v historično paradigmo. Prednost, s katero želiva zagovarjati ta pristop, je v njegovi kompleksnosti. Ta je med drugim možna zaradi predhodnega vpogleda v konstrukcije spolov na področju izobraževanja in medijev/novih medijev na eni strani, na drugi pa zaradi kritično naravnanega strokovnega poznavanja industrije konstrukcij sprege spolnosti in nasilja, katerih ciljna skupina so poleg odraslih tudi otroci in mladoletni, in njene regulacije. Gre za že opravljeno, čeprav časovno zamejeno analizo konceptov in pojmovanj v izbranih socioloških, feministično teoretskih, pravnih, državnonadzornih in medijskih diskurzih (Šribar, 2006).

$\mathrm{Na}$ terenski raziskovalni ravni, ki je povezana z otroki in mladimi, so najin predmet same (čutno-nazorne) vsebine medijev in novih medijev in nji-

${ }^{5}$ Sintagma je parafraza, historična nadgradnja konceptualizacije kulture skozi sintagno »spolnost in nasilje« (Williams, 1997). 
hovi učinki na pojmovanja, odnose, vedenje. Kot ilustracijo teoretskih tez in konceptov zato vključujeva posamezna pričevanja, stvarne zgodbe iz šolskega okolja in vsakdanjega življenja, ki kažejo na način povezanosti obravnavanih vsebin in storitev ter tehnologije s spolnim ali seksualiziranim nasiljem in nasiljem nasploh.

Kot že implicirano, bi morala pričujoča študija pomeniti izhodiščno točko za demokratizacijo šole in izobraževalnih programov ter projektov informiranja in osveščanja o spolnih vlogah, spolnem zdravju in preprečevanju spolnega nasilja ter nasilja v novomedijskih razmerjih. Za tako zastavljenim namenom študije je možnost za spolno nehierarhizirano odraščanje s konstruktivnejšo samopodobo in ustvarjanje pogojev za oblikovanje samozaščitnega vedenja $v$ medosebnih odnosih in seksualnosti. Samozavestni in kompetentni mladi se bolje dokazujejo tudi pri svoji izobrazbeni in poklicni izbiri. Dolgoročno bi lahko imela država na ta način v svojem podmladku dobro perspektivo, beležila pa bi tudi kratkoročne pozitivne učinke na področju zdravja, še posebej spolnega in reproduktivnega.

$\mathrm{Z}$ nakazanim konceptualnim okvirom in usmeritvami za aplikacijo bova, vsaj upava tako, zajedli v manko, ki je v veliki meri tudi posledica velike tehnološke razvitosti Slovenije in nepopolne ali odsotne vzgoje in izobraževanja, informiranja in ozaveščanja na obravnavanem področju; slednje je gotovo tudi učinek vladajočega neoliberalnega javnega mnenja $\mathrm{v}$ zvezi s potencialno škodljivimi vsebinami in drugimi $\gg$ tveganji $\ll v$ novomedijskih razmerjih. Preden pa se lotiva natančnejšega vpogleda v sfero vzgoje in izobraževanja ter novih medijev iz perspektive odraščanja, predstavljava svoja epistemološka izhodišča in metodološke pristope. 

transformacijam

nekaterih temeljnih

epistemoloških

pojmov skozi

feministično teorijo

zadnjih desetletjih so dela s področja feministične teorije postavila nekatere temeljne izzive obstoječim družboslovnim analizam

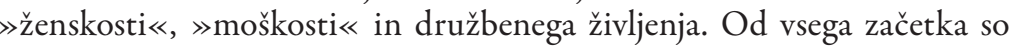
bila vprašanja o metodah, metodologiji in epistemologiji povezana $\mathrm{z}$ razpravami o smiselnosti in upravičenosti parcialnih in »popačenih « prispevkov v tradicionalnih analizah (Harding, v Harding, 1987: 1). ${ }^{1}$ Najino izhodišče (kar je bolj usmeritev kot definicija) je, da gre pri feminizmu za kritičen pogled, $\gg$ ki sledi kritičnemu pozicioniranju v nehomogenem, spolno zaznamovanem družbenem prostoru « (Haraway, 1999: 312). ${ }^{2} \mathrm{Na}$ kratko bi lahko tudi dejali, da izhodišče predstavlja »spopadanje « s hierarhičnimi modeli ustvarjanja in distribucije vednosti ter kritičen odnos do tradicionalnih znanstvenih izjav kot »univerzalnih « resnic.

Feministična epistemologija je (grobo rečeno) del feminističnega teoretiziranja spola in tradicionalne epistemološke problematike. Poudarek je

\footnotetext{
${ }^{1}$ Poudariti pa je treba, da ne gre za uveljavljanje kakih specifično feminističnih metod. S. Harding poudarja, da je treba vsekakor najprej razplesti zmešnjavo, ki se rada pojavi zaradi površne rabe izrazov »metoda«, »metodologija « in »epistemologija «. Znanstvene metodologije in prakse se med sabo razlikujejo, a specifična tarča feministk ni znanstvena metoda na splošno, marveč posebna aplikacija znanstvene metode, v grobem znana kot pozitivizem (zelo splošen in sporen pojem) - vidik, ki ga feministke najbolj napadajo, je trditev, da stroga pravila produkcije vednosti lahko preprečijo, da bi na povezave med vednostjo in realnostjo vplivale vrednote raziskovalca. V literaturi je včasih tudi zmeda, ker se določeni vidiki pozitivistične metodologije predstavljajo kot načela znanosti na splošno (Ramazanoğlu, 2002: 45).

${ }^{2}$ Pozicioniranje - k čemur se še vrneva v nadaljevanju - je, kot piše E. D. Bahovec, zelo pomembno, da »opozorimo na iluzijo nevtralne, obče, objektivne oziroma na videz nevtralne, iluzorno obče, zavajajoče objektivne pozicije univerzalnega ' $m i$ '. Toda ni vsako pozicioniranje tudi že subverzivno.« (Bahovec, 2007: 16.)
} 
na načinih, na katere so vedoči/spoznavajoči partikularni in konkretni, ne pa abstraktni in univerzalni. Z drugimi besedami, vedno smo vpleteni $\mathrm{v}$ družbena razmerja, ki so v splošnem hierarhična, pa tudi zgodovinsko in kulturno specifična, kar - poenostavljeno - vpliva na to, kako razbiramo svet okoli sebe. Ti načini pa so nadalje pomembni za epistemološke probleme in naše razumevanje izrazov, kot so »objektivnost «, »racionalnost «, »vednost « (Janack, 2004), pa tudi »napredek«, »izkustvo« ipd. - izrazov, ki se običajno zdijo samoumevni in nespremenljivi (kot da so tu od nekdaj). Te feministična teorija kritično vrednoti in postavlja pod vprašaj njihovo univerzalno veljavnost in vrednost.

Feministično epistemologijo opisujeva - sicer ohlapno - kot pristop $\mathrm{k}$ epistemologiji, in ne kot šolo ali enotno teorijo, ki poudarja epistemsko pomembnost spola. Spol uporablja kot osrednjo kategorijo v razpravah in rekonstrukcijah epistemskih praks, norm in idealov. Seveda ne trdiva, da so vse predpostavke, problemi in teme, ki jih navezujeva na feministično teorijo in epistemologijo, izključno $\mathrm{v}$ domeni feminizma, pojavljajo se tudi $\mathrm{v}$ drugih epistemologijah in filozofskih tradicijah (Janack, 2004; Felski, 2000: 198), marveč da jim je prav feminizem podelil specifično dimenzijo in razvil specifične - nove - premisleke. Ta heterogenost polja feministične epistemologije je nemara tudi razlog, da je težko opredeliti, v katero smer se razvija ali bi se morala razvijati. Ker nama zasnova ne dopušča podrobne predstavitve obsežnega korpusa del s tega področja, se omejujeva na nekatera temeljna izhodišča in pojme, druga pa izpuščava ali se jih zgolj dotakneva, kar včasih pomeni tudi vzeti kaj iz konteksta in predstaviti, kot da bi bila to $\gg$ cela zgodba $\ll$.

Projekt feministične epistemologije je torej razložiti povezave med konstrukcijo vednosti ter družbenimi in političnimi interesi. Povezava vednosti in oblasti, torej raziskovanje povezav med zatiranjem po spolu in praksami iskanja vednosti, in ugotovitev, da je legitimizacija vednostnih trditev intimno povezana z omrežji dominacije in izključitve, je epistemološka vprašanja premaknila z obrobja posameznih disciplin v središče sodobne kulture (Lennon in Whitford, v Lennon in Whitford 1994: 1). ${ }^{3}$

\footnotetext{
${ }^{3}$ Odsotnost razmisleka o povezavah vednosti in oblasti vodi v prepričanje, da imajo znanstveniki v lasti znanost, občasno pa sicer ujamejo vdiralce, ki poskušajo izvleči kulturne implikacije, ne da bi si prej pridobili ustrezno znanstveno izobrazbo (zato naj bi bila denimo mogoča Sokalova prevara). Po drugi strani pa so znanstveniki upodobljeni kot skromni garači, katerih pristojnosti ne segajo čez meje laboratorija. Vidimo, kako znanstveniki položijo celoten zemljevid človeškega genoma na prag javnosti, potem pa se hitro umaknejo k svojemu naslednjemu projektu, ne da bi se vključevali v politične implikacije tega, kar so storili. Tu je čistost (odsotnost političnih odločitev) zelo blizu božanskosti (Fuller, 2002: 96).
} 
Implikacije za epistemologijo so tako vsaj tri: prvič, spoznavajoči subjekt ni zunanji družbenim razmerjem, ampak ga ta konstituirajo; drugič, politične vrednote niso izključene iz vednosti, ampak so epistemološko pomembne; in tretjič, vednost ni objektivno zrcalo zunanjega sveta, konstruirajo jo družbene prakse (Campbell, 2004b: 14).

Eden od temeljnih kamnov feministične teorije $\mathrm{v} v$ seh različicah je izziv pozitivističnim pojmom objektivnosti in resnice. Tu obstaja velik razpon feminističnih pozicij, ki segajo od feminističnega empiricizma, ki si ne prizadeva preoblikovati okvirja znanosti kot take, ampak bolje opraviti v obstoječem, do postmodernih teoretičark, ki zavračajo vsak pojem objektivnosti in resnice. Kljub razlikam pa so vse postavile pod vprašaj, kot pravita M. Stoetzler in N. Yuval-Davis (2002: 315), božji trik, ki obljublja pogled od povsod in od nikoder v enakem in popolnem obsegu (slavna besedna zveza D. Haraway, 1999: 306), kot krinko in legitimizacijo hegemonskega maskulinističnega pozicioniranja. Največji izziv, ki je bil in je pred feministično epistemologijo, pa je iskanje načinov za konceptualizacijo in razumevanje mrež opresije in njihovih epistemskih učinkov. Trije »tradicionalni « feministični pristopi - feministični empiricizem, teorija stališč in postmodernizem so bili do sedaj neustrezni (Grasswick in Webb, 2002: 194).

Feministična epistemologija je relativno novo polje, ki se je začelo oblikovati v začetku osemdesetih let prejšnjega stoletja (Grasswick in Webb, 2002: 185). V zgodnji formulaciji objekta preučevanja feministične epistemologije ta ni bila predstavljena kot epistemologija, marveč je šlo za epistemološke implikacije feministične politike: ali obstaja oziroma ali lahko obstaja jasna feministična perspektiva epistemologije, metafizike, metodologije in filozofije znanosti (Harding in Hintikka, nav. po Campbell, 2004b: 10)?

Identifikacija feministične epistemologije s politično dimenzijo ter osvetlitvijo povezav med političnim in epistemskim pomaga razjasniti pogosto zabrisano razliko med »ženskimi epistemologijami« in »feminističnimi epistemologijami«. Medtem ko prve temeljijo na ohranjanju spolnega razcepa pri načinih spoznavanja, pa je za druge značilna njihova eksplicitna povezava $z$ družbenimi in političnimi cilji izboljšanja življenja žensk (Grasswick in Webb, 2002: 187). V končni fazi je bil spol (gender) razvit kot kategorija, s katero raziskujemo, kaj je »ženska«, problematiziramo samoumevnosti in rekonstituiramo to, kar velja za občečloveško (Haraway, 1992: 96; Prins, 1995: 357).

$\mathrm{Na}$ to neupravičeno zabrisano razliko med $\gg$ ženskimi epistemologija$\mathrm{mi}$ in $\gg$ feminističnimi epistemologijami je treba vedno znova opozar- 
jati, saj se v bolj ali manj poglobljenih razpravah vedno znova pojavi kot posledica (ne)namernega spregleda že razjasnjenih problemov (npr. Pinnick et al., 2003). ${ }^{4}$ Feministične epistemologije ne razumemo kot preučevanja ženskih načinov spoznavanja, čeprav je pogosto tako (napačno?) razumljena, kar vodi $v$ dvomljive trditve o ženskih spoznavnih razlikah. Zdrs ženskega in feminističnega $\mathrm{v}$ eno in predpostavljanje, da so vse ženske $\mathrm{v}$ bistvu feministke, je napačen, saj biti izkoriščan še zdaleč ni porok jasnosti pogleda ali posedovanja resnice (Felski, 2000: 197, in nasl.). Tu ni nekega avtomatskega epistemskega privilegija. Vzpostavljanje apriorne povezave med strukturno pozicijo in opozicijsko zavestjo ne zdrži na nobeni ravni, saj ne moremo predpostavljati, da je patriarhalna ideologija homogen in uniformno represiven pojav, ki zakriva pravo žensko subjektivnost, ne pa kompleksna formacija, ki prežema življenja obojih, moških in žensk.

Feministično raziskovanje mora biti namreč del procesa, v katerem se neenakosti ne le opisujejo, ampak tudi reflektirajo in spodbijajo (Gorelick, 1991: 462). Ali drugače: vključitev dimenzije spola, opisna statistika ali izkustveni podatki o ženskah sami po sebi še ne naredijo razprave za feministično. Samo preučevanje spola še ne vnese feministične dimenzije (tega ni mogoče dovolj poudariti). Tudi če je vključena dimenzija spola, izsledki pogosto ponavljajo in utrjujejo prav tiste rigidnosti in tradicionalne podobe spolov, ki jih vsaj načelno poskušajo preseči (ali pa seveda tudi ne). $\mathrm{Na}$ primer: preučevanja zlorabe otrok so zlorabo predstavila kot redek odklon ali kot nekaj, za kar je treba kriviti perverzne otroke ali njihove (slabe) matere (Ramazanoğlu, 2002: 147). Razprava (ali raziskovanje) je lahko dojeta kot feministična, če jo uokvirja feministična teorija in če je njen cilj produkcija vednosti, ki bo uporabna pri učinkoviti transformaciji ospoljene nepravičnosti in podrejenosti. To pa ne pomeni, da morajo feministke preučevati ženske ali samo preučevati spol ali šteti ženske za nedolžne žrtve oblasti (Ramazanoğlu, 2002: 147).

Projekt feministične epistemologije glede na teoretsko vednost ima dva primarna cilja (Longino, nav. po Anderson, 1995: 51). Prvič, poskuša razložiti dosežke feministične kritike znanosti, ki jo zanima razkrivanje androcentrizma v teoretskem razmisleku. Adekvatna feministična epistemologija mora razložiti, kaj pomeni, da je znanstvena teorija ali praksa seksistična ali androcentrična, kako se te poteze izražajo v teoretskem razmisle$\mathrm{ku}$ in aplikaciji teoretske vednosti in kakšen vpliv imajo te poteze na evalvacijo raziskovanja. Drugič, projekt feministične epistemologije brani fe-

${ }^{4}$ Toda »čeprav ni na 'ženski' nič inherentno feminističnega, prej nasprotno, pa na feminizmu je nekaj 'ženskega'.« (Bahovec, 2007: 34.) 
ministične znanstvene prakse, ki vključujejo zavezo osvoboditvi žensk ter družbeno in politično enakost vseh. Adekvatna feministična epistemologija mora razložiti, kako lahko projekti s takimi moralnimi in političnimi zavezami producirajo vednost, ki ustreza epistemskim merilom, kot sta empirična ustreznost/primernost in plodnost.

V tem smislu je feministična epistemologija tudi del t. i. »znanstvenih vojn«, kjer imamo, kot se zdi, na eni strani branilce zahodne znanosti in tradicionalne razsvetljenske racionalnosti, ki so uperjeni proti »alternativnim «, čisto neznanstvenim načinom razbiranja in razumevanja sveta okoli nas. Neogibno - čeprav ne nujno dokončno $0^{5}$ - presečišče »rase, razreda in spola« ali poudarjanje »belih, zahodnih, moških vrednot « opredeljujejo kot stokanje politično korektnih. Na drugi strani pa so postmoderna, ${ }^{6}$ postkolonialna in feministična preučevanja, ki poskušajo pokazati, kako je precejšen del izsledkov te prve strani prepreden s sovražnostjo in prezirom, ne pa substancialnimi analizami. Na tej strani slišimo, da hoče prva stran očistiti zrak škodljivih hlapov, ki prihajajo od družbenih in kulturnih kritik znanosti (Linker, 2005: 452). ${ }^{7}$ Najbrž sta obe strani »razcepa « krivi za selektivno pozornost in pretirano generalizacijo (Giere, 1999: 4). Vse večja publiciteta pa hkrati odseva in krepi naraščajočo polarizacijo, tako da se zdi, da obstajata dve strani: razsvetljenski racionalisti, zaničljivo poimenovani tudi redukcionisti ali esencialisti, in pa relativisti ali postmodernisti (Giere, 1999: 1).

Glavni nauk, ki ga je mogoče povzeti po Kuhnu (npr. 1998) in številnih drugih, je, da so prav kategorije, s katerimi se je formuliral razsvetljenski pogled na znanost, nezadostne, da bi zajele dejanske znanstvene prakse, tako zgodovinsko kot v sodobnih oblikah. Mnogi na obeh straneh tega »razcepa« (tj. razcepa med t. i. razsvetljenskimi racionalisti in postmodernimi relativisti) so, kot se zdi, tako ponotranjili tak pogled na znanost, da je zanje spodbijanje vidikov tega pogleda enako spodbijanju znanosti (Giere, 1999: 3).

\footnotetext{
${ }^{5}$ Logična implikacija pozicije, ki poskuša »spraviti pod streho《 vse kompleksnosti, je lahko v končni fazi tudi vprašanje prioritet, kar je pogosto karikirano spričo možnosti novih in novih družbenih delitev (gl. npr. Cealey Harrison in Hood-Williams, 1998).

${ }^{6}$ To je - kot se zdi - zaenkrat precej nejasno poimenovanje, ki lahko opisuje marsikaj: od zavračanja znanosti kot moškega početja (prim. Nye, 2000: 200) do znanosti v dobi subatomske fizike, kot meni E. R. Klein (1993: 68).

${ }^{7}$ Kaj pravzaprav pomeni zmagati v znanstvenih vojnah, se sprašuje S. Fuller. Nekateri znanstveniki se največ ukvarjajo $\mathrm{z}$ ožigosanjem površnega raziskovanja $\mathrm{v}$ akademski sferi, drugi z reševanjem levice pred postmoderno dekadentnostjo. Fuller pravi, da mu gre za to, da se opravi z mistifikacijami, ki obkrožajo ukvarjanje z znanostjo, še posebej v povezavi s širšo legitimizacijsko vlogo v družbi (Fuller, 2006: 112).
} 
Gornja delitev na »prave « in »neprave « je sicer groba in morda tudi poenostavljajoča, ne glede na to, $s$ katerega konca jo beremo, vendar ima vsaj majceno zrno soli, ki se kaže kot potencial za razvijanje pozornosti v več smeri, tudi v smeri morebitnega poenostavljanja feminističnega ukvarjanja z znanostjo. Denimo, kritika slabe znanosti utegne zdrseti v skrajno doktrino, da so vse znanstvene izjave (produkti »moške «nanosti) zgodovinske izmišljije, ki jih je oblast spremenila v dejstva, in pripelje do težav, ko je treba začeti proizvajati znanost, ki bi bila resničnejša in boljša (Haraway, 1999: 130). To lahko na epistemološki ravni (kar je mamljivo, a zelo sporno) pomeni diferenciacijo dveh epistemoloških sistemov: »uradnega, $\mathrm{v}$ katerem prevladujejo moška racionalnost in načini delovanja, skozi katerega se uveljavljajo patriarhalni interesi, in drugega, ki je vdelan v vsakdanje dejavnosti in izkušnje žensk, ki so izključene iz javnega/političnega diskurza (Currie,1992: 354, in nasl.). ${ }^{8}$ Ta dihotomija se pogosto ponuja kar sama, je pa problematična, saj poleg tega nekako predpostavlja, da slaba znanost, zgoraj omenjeni prvi epistemološki sistem, ni vzniknila naključno, ampak sistematično.

Ali bi morale feministke potemtakem proizvajati zrcalne zgodbe ne meneč se za retorično dediščino patriarhalnega glasu oziroma sprožiti epistemološko revolucijo, ki ne bi bila na noben način povezana z zgodbami, ki nam jih je povedal patriarhalni glas? Feministična »teoretična težava « je prav v tem: ali je treba raziskovati na način, soroden obstoječim teorijam reprezentacije, ali razviti radikalno nove in kako?

A vse skupaj bi tu raje zastavili nekoliko drugače: da feministično raziskovanje temelji na kritičnem odnosu do tradicionalnih znanstvenih izjav kot univerzalnih resnic, kar lahko vodi v boljšo, odgovornejšo in, denimo, globalno pravičnejšo znanost. Tu gre za resna, konceptualno razvita preučevanja, ki so sposobna tudi samorefleksije in samokritike. Vprašanje je, ali za epistemologijo sploh lahko označimo kar koli manj strogega, čeprav se vedno znova najdejo očitki, ki kot bistvene značilnosti feministične epistemologije navajajo: ${ }^{9}$ politično korektnost, s katero naj bi preprosto pometli z resnicami, ki so neprijetne za feministično agendo; tribalizem, kar pomeni, da vse ženske in vse feministke mislijo enako, žensko pa je sploh enako feministično, obstaja tudi neki »ženski« epistemski stil; samouničujoč

\footnotetext{
${ }^{8}$ Subjektivna vednost pogosto izzveni v trditev o relativnosti vse vednosti. Pozicija, v kateri subjektivnosti ne ovira nikakršna objektivnost ali težnja po njej, sicer lahko hitro zdrsne v čisti subjektivizem, $\mathrm{v}$ katerem vednostne trditve temeljijo izključno na občutjih, mnenjih, preferencah ipd. (Currie, 1992: 344).

${ }^{9}$ Gl. Pinnick et al., 2003, in natančno (in dokaj utemeljeno) zavrnitev vseh teh očitkov v Anderson.
} 
konzervativizem, do katerega je pripeljal radikalni relativizem, ki nekritično slavi nezahodne vrednote in vednostne sisteme, ki so pogosto zatiralski; in končno cinizem - zavračanje objektivnosti in resnice kot nemogočih v oblastni igri.

Velik del feministične epistemologije je bil spričo tega »reakcijski« (Grasswick in Webb, 2002: 194), tj., ukvarjal se je s tem, da je »mainstreamovski epistemologiji upravičeval svojo eksistenco in se spopadal z bolj - zelo pogosto pa manj - upravičenimi očitki. ${ }^{10}$ M. Linker (2000: 184, in nasl.) pri pregledu kritik feministične epistemologije med drugim denimo navaja »the unimaginability argument « - kaj pa bi lahko bila tale feministična epistemologija? In kaj bi lahko bila feministična znanost, ki je očitno dojeta tudi kot projekt izjemne razsežnosti reinvencije tradicionalne znanosti?

\section{»Utelešena « znanost in »dejstva «}

$\gg$ Zdi se,« je v Treh gvinejah zapisala V. Woolf, »da znanost ni brezspolna, moški je, oče, in prav tako okužena.« (Woolf, 2000: 135.) S tem (slavnim) citatom začrtujeva (vsaj) dve liniji, ki prepredata feministično ukvarjanje z znanostjo in epistemologijo oziroma feministično epistemologijo kot nekakšno nadgradnjo feminističnega ukvarjanja s spolom in temami tradicionalne epistemologije. Prvič, kot nadaljuje V. Woolf na istem mestu, je tako okužena znanost predložila meritve po naročilu - meritve možganov, za katere so profesorji dejali, da jih je narava naredila za nesposobne opravljanja izpitov. Prva linija torej vodi v razkrivanje moškega predsodka $\mathrm{v}$ znanosti, ki na institucionalni ravni onemogoča ali zavira polno/enakopravno/neovirano vključevanje žensk v znanost. To linijo, ki jo zanimajo pogoji produkcije znanosti in »pohod « skozi institucije, tule puščava ob strani. Sem sodi tako problematika žensk, ki so jim določene poklicne poti (še vedno) zaprte ali vsaj omejene, na kar kaže denimo upadanje števila žensk, čim višje po hierarhično-znanstveni vertikali gremo, pa tudi - kar je nemara zanimivejše, ker že nakazuje premik od reprezentiranosti po spolu k nekoliko bolj, a ne še čisto, konceptualnim vprašanjem, ki jih srečamo v drugi liniji - vrednotenje njihovega dela in dosežkov oziroma prispevkov $\mathrm{k}$ znanosti, ki je bilo v še ne tako davni zgodovini naravnost omalovažujoče.

$\mathrm{V}$ feministični tradiciji je denimo zelo prisoten problem odsotnih žensk. E. D. Bahovec svetuje previdnost pri odkrivanju in preštevanju ženskih imen (ničelni stopnji boja za miselno tradicijo) ter slavljenju njihovih

\footnotetext{
10 »Argumenti《 so pogosto bolj napadi ad hominem kot pa resno argumentiranje (prim. Linker, 2000; Vendramin, 2009).
} 
prispevkov, kar hitro lahko postane stranpot. Predlaga, da »problematično tradicionalno vednost vzamemo zares in prispevke žensk ovrednotimo z imanentnimi kriteriji samega področja, hkrati pa te kriterije v naslednji fazi postavimo pod vprašaj, se skratka lotimo epistemologizacije (Bahovec, 2007: 31, in nasl.).

Druga linija - kolikor ju lahko ločujemo - pa »androcentrično « znanstveno okužbo, o kateri govori Virginia Woolf, zastavlja na drugi, znanosti bolj »notranji《 ravni, saj načenja temeljna vprašanja o naravi resnice, vednosti in objektivnosti. Izpostavlja družbeno vpetost znanosti, ki vpliva na to, kaj vidimo in kako to vidimo, kako podatke filtriramo in kako se konec koncev zavedamo različnih konstrukcij v na prvi pogled nevtralnih znanstvenih praksah. Z drugimi besedami: tudi najbolj rigorozne raziskovalne procedure so lahko prepredene s problematičnimi postavkami, ki jih ni lahko identificirati, kaj šele eliminirati, kar dokazuje veliko število primerov iz zgodovine znanosti: ${ }^{11}$ kaj raziskovati, kateri so koncepti v hipotezah, ki jih preizkušamo itn. Na kratko, kritično vrednotenje temeljnih konceptov in konceptualnih sistemov pa tudi znanstvenih rezultatov pokaže prisotnost vrednot, kontekstualnih dejavnikov, predsodkov ter družbenih, kulturnih in zgodovinskih potez (kar je problematično ravno in predvsem zato, ker ni vdelano $\mathrm{v}$ te iste koncepte). $\mathrm{Na}$ ta način totalizacije znanstvenik/avtor zatrjuje, da gleda od povsod in da vidi vse, da nima želja, potreb, prepričanj in ozadij. Gould (2000: 47), ki je prav tako kritik tovrstnega mita o objektivnosti, ${ }^{12}$ pravi, da ne gre za to, da bi zoperstavljali zlobneže, ki skrenejo s poti znanstvene objektivnosti, in razsvetljence, ki se odprtih misli lotevajo podatkov in zatorej vidijo resnico, marveč za to, da znanost ni objektivno početje, ki pravilno deluje le, če se znanstveniki znebijo omejitev svojih kultur in vidijo svet tak, kakršen je v resnici.

Znanost - tudi S. Gould uporabi isti medicinski besednjak kot V. Woolf - je podvržena družbenim in političnim okužbam, podatke je mogoče filtrirati skozi predsodke (2000: 46, in 53):

Velik del njenega spreminjanja v času ne beleži približevanja absolutni resnici, temveč spremembe kulturnih kontekstov, ki tako močno vplivajo nanjo. Dejstva niso čiste in neoporečne informacije; tudi kultura vpliva na to, kaj vidimo in kako to vidimo. Še več, teorije niso neomajna sklepanja na podlagi dejstev.

\footnotetext{
${ }^{11}$ Gl. npr. Harding, 1991: 144, op. 7. Gl. tudi Haraway, 1996, ali Fausto-Sterling, 1992.

${ }^{12}$ Pojem tu lahko obdelava le delno, različne modalitete ostajajo ob strani, kot npr.: objektivnost kot vrednostno nevtralna drža, kot brezinteresna drža, kot nepristranska ipd. (prim. npr. tudi Klein, 1993: 58, in nasl.).
} 
Najustvarjalnejše teorije so pogosto domiselne vizije, položene na dejstva (Gould, 2000: 47).

Če priznamo omejitve znanosti, ki ji jih nalaga njena družbena vpetost, $s$ tem še nismo diskreditirali znanosti (morda prav nasprotno), čeprav je ta trditev in z njo povezane trditve anatema za mnoge praktične znanstvenike, kot pravi Gould. To pa spet ne pomeni - morda ni odveč ponoviti, pač z drugimi besedami -, da $s$ tem soglašamo $s$ »povsem relativistično trditvijo, da je spreminjanje znanosti le odsev modificiranja družbenih kontekstov, da je resnica zunaj kulturnih predpostavk nepomemben pojem in da znanost torej ne more podati trajnih odgovorov« (Gould, 2000: 48). Znanost ne more ubežati svoji čudni dialektiki, kar pomeni, da je kljub vpetosti v kulturo lahko močno gibalo prevpraševanja in zavračanje podmen, ki jo napajajo:

Znanstveniki se lahko trudijo identificirati kulturne predpostavke svoje stroke [...]. Znanstveniki lahko predlagajo ustvarjalne teorije, ki prisilijo osuple kolege, da se spopadejo z nevprašljivimi postopki. Vendar potenciala znanosti kot instrumenta za identificiranje kulturnih zadržkov, ki jo omejujejo, ni mogoče v celoti uresničiti, dokler se znanstveniki ne odpovedo dvostranskemu mitu o objektivnosti in neomajnemu pohodu k resnici (Gould, 2000: 48-49).

Vendar pa je treba »napredovati« previdno, začeti (in tudi opraviti) je treba z nemara najosnovnejšim vprašanjem, ki bo že začrtalo osnovno linijo, in to je: smemo od žensk v znanosti pričakovati kar koli drugega kot od moških (Haraway, 1999: 136)? D. Haraway takole nadaljuje z izpeljavami tega vprašanja: bi se morale feministke osredotočati na kritiko seksistične znanosti in pogojev njene produkcije? Ali pa bi nemara morale postaviti temelje za epistemološko revolucijo, ki bo razsvetlila vse strani znanstvene vednosti? Ali naj bi bila feministična epistemologija sorodna obstoječim teorijam reprezentacije ali pa naj feministke raje privzamejo radikalno obliko epistemologije, ki zanika možnost dostopa do realnega sveta in objektivnost? Ali bi feministke morale sprožiti epistemološko revolucijo, ki ne bi bila na noben način povezana z zgodbami, ki nam jih je povedal patriarhalni glas? Sprašujemo se lahko tudi, ali nastaja specifično feministična teorija vednosti ter ali bi feministični standardi vednosti končali dilemo o razcepu med subjektom in objektom in ponudili novo zgodbo, novo identiteto znanosti? In po drugi strani: kaj pa razmerje med vednostjo in oblastjo, na kar »tradicionalna « znanost kar prevečkrat pozabi (Haraway, 1999: 119, in nasl.)? 
Ta vprašanja so poleg tega, da po eni strani zarisujejo obseg zanimanja feministične epistemologije tako $\mathrm{v}$ širino kot globino, po drugi nadvse prikladna za spotikanje kritikov in tistih, ki so na splošno nenaklonjeni takim in podobnim projektom, ker (ob zelo površnem branju, a vendarle) odpirajo vrata za zavračanje na podlagi domnevne politične korektnosti, ki naj bi bila - po njihovem - glavno načelo feministične epistemologije. In to ne velja le za kritike $\gg z$ drugega brega «, ampak pogosto tudi za kritičarke in zgodovinarke znanosti - vsi pa zavračajo feministično epistemologijo kot popolno konceptualno, znanstveno in še kakšno katastrofo. ${ }^{13}$

Politična korektnost seveda $\mathrm{v}$ znanosti nima kaj iskati. A to je vendarle treba precizirati, kajti očitek politične korektnosti je »najresnejša obtožba proti feministični epistemologiji, ker feministke obtožuje ne le napak ali cinizma, marveč intelektualne nepoštenosti, dogmatizma in celo tiranije« (Anderson). Honest inquiry, h kateremu poziva S. Haack (v Pinnick et al., 2003: 14, in nasl.) in ki zanjo pomeni tako raziskovanje, ki ni na noben način povezano s političnimi idejami, je lahko na ta način že problematično. S. Haack meni, da vse, kar sodi pod oznako feministična epistemologija, izhaja iz predpostavke, da mora biti raziskovanje politizirano, kar je po njenem mnenju ne le napačno, ampak tudi nevarno. Tu se je treba spustiti $\mathrm{v}$ dlakocepljenje in obrniti perspektivo: feministična epistemologija (resna, reflektirana in samokritična) ne postavlja zahtev po politiziranem raziskovanju (v smislu: »prava vsebina znanosti je samo tisto, kar ustreza nam« oziroma določenim političnim interesom), ampak se - nasprotno - sprašuje, v kakšni meri je (vsako) raziskovanje »politizirano « in kakšne so sploh možnosti »politično nevtralnega « in tudi sicer od vseh parcialnih interesov ločenega raziskovanja.

Malo kasneje se $S$. Haack tega spet dotakne z besedami, da je seveda mogoče, da včasih znanstveniki vidijo relevantne dokaze kot relevantne le, ko jih določeni pritiski prepričajo o predhodnih predsodkih. »A take resnice, « nadaljuje $S$. Haack, »nimajo radikalnih posledic, iz njih ne sledi, da je npr. realnost taka, kot jo določi kaka epistemska skupnost, ali da relevantnost dokaza ni objektivna.«(V Pinnick et al., 2003: 14.) Tole pa je vseeno preveč preprosto. Znanstvena dejstva morajo ustrezati pogledu na svet nekega časa in veliko znanstvenih dejstev je protiintuitivnih (Hubbard,

\footnotetext{
${ }^{13}$ Pinnick et al. (2003) brenkajo na iste, že zelo obrabljene strune in pretepajo konje, kot pravi E. Anderson (če si dovoliva neposreden prevod angleškega izraza), ki so že davno poginili v internih razpravah na tem polju. Za podrobno in utemeljeno zavrnitev tovrstnih kritik gl. Anderson.
} 
1988: 6, in nasl.): se Sonce vrti okoli Zemlje ali nasprotno? Kar je danes samoumevno, pred nekaj sto leti ni bilo. ${ }^{14}$

Z drugimi besedami, feministke ne pravijo, da je treba vse vrzeli v znanstvenem razmišljanju napolniti s sociopolitičnimi kavzalnimi razlagami, ampak da je obstaja možnost, da so sociopolitične vrednote vplivale na vsebino - govorimo o možnostih, ne nujnostih (Anderson). ${ }^{15}$ Še enkrat: feministična epistemologinja dopušča politične interese kot relevantno omejitev znanstvenemu razmisleku (Anderson). Ni se mogoče namreč strinjati, da brezinteresno (disinterested) pomeni hkrati tudi $\gg$ brezlocirano $\ll(d i-$ slocated), tj. neodgovornost za kompleksne plasti osebne kolektivne zgodovinske umeščenosti $\mathrm{v}$ aparate za produkcijo vednosti ali nezavedanje o tem. Prav tako ne moremo dovoliti, da bi »politično angažirano « pomenilo »pristrano « (Haraway, 1997: 277).

Tu se ne moreva podrobno spuščati v pogoje nastajanja/oblikovanja znanstvene vednosti, a vendarle izpostavljava, da izbire, ki jih je treba opraviti v luči znanstvenih ciljev in ki so nujne, če hočemo sploh začeti raziskovati, vnaprej omejujejo hipoteze, ki jih raziskujemo (na grobo: kaj raziskovati, na katera vprašanja dobiti odgovore, katere postopke izbrati za pridobivanje podatkov itn.) (Kourany, v Pinnick et al., 2003: 210; Anderson). Tu neogibno vstopijo vrednote. Zato je znanost »družbeno vpeta dejavnost « in ta vpetost (družbena, kulturna ...) vpliva na to, kaj vidimo in kako to vidimo. ${ }^{16}$

Znan primer iz zgodovine znanosti, ki si spričo tematike te knjige zasluži malo večjo pozornost, je eksperimentalna praksa primerjalnega psihologa H. Harlowa. D. Haraway (1996) je podrobno obdelala to prakso iz časa, ko so bile primatske raziskave nesporne in pomemben vir pridobivanja splošnih (vseh mogočih) vednosti, torej z začetka druge polovice prejšnjega stoletja, in znanstveno fantazmatiko Harlowove laboratorijske matere, s katero so opicam nadomestili biološko mater. Harlowov laborato-

\footnotetext{
${ }^{14}$ Poleg tega: je mogoče, da se take vrste fizika, za katero se podeljujejo Nobelove nagrade (denimo S. Weinbergu za prispevek $\mathrm{k}$ teoriji poenotenja šibke jedrske in elektromagnetne interakcije), podpira zato, ker jo je mogoče uporabiti za neepistemske cilje (npr. razvoj jedrskega orožja), in ne zato, ker bi bila epistemsko pomembnejša od drugih (Fuller, 2002: 102)?

${ }^{15}$ Možno je seveda tudi, da obstajajo področja človeške vednosti, ki so taki »okužbi« bolj podvržena kot druga. To je zelo provizorična teza, saj bi bilo treba za dokončen odgovor preučiti vpletenost (kakršnega koli) predsodka v znanstvene koncepte.

${ }^{16}$ In tudi, kako to merimo in izmerimo. Dober primer je biološki determinizem oz. dednostne interpretacije inteligenčnostnega količnika v predpreteklem in preteklem stoletju, kar je podrobno obdelal S. J. Gould v svojem delu Za-mera človeka (2000). Gould to označi kot »poglavitno zlorabo znanosti v tem [tj. dvajsetem] stoletju« (Gould, 2000: 177).
} 
rij je uspešno redil primate $\mathrm{v}$ službi primerjalne psihologije, ki je »merila opičji razum in čustva v službi liberalnih reform v socialnih službah, šolstvu, psihiatriji in družinskem življenju « (Haraway, 1996: 138). D. Haraway je pokazala, kako zelo so bile interpretacije v raziskavah vedenja primatov ospoljene in kako so odražale umeščenost raziskovalca vsaj toliko kot dejansko dinamiko tistega, kar je raziskoval, torej primatskih družbenih skupin. Opisi poskusov H. Harlowa na rezusih, v katerih je preučeval psihološke posledice odsotnosti materinskega stika, so tako in drugače boleče branje. Mladičke je ločil od pravih mater in jim dal različne nadomestne matere - brez glave, $\mathrm{z}$ eno dojko, hladne, tople, take $s$ katapultom, ki so metale mladička proč od sebe, ipd. Ta raziskava znanstvene materinskosti se je naslavljala na socialne probleme človeškega materinstva v kontekstu zahodnih ekonomskih in spolnih ureditev po drugi svetovni vojni (Haraway, 1996).

Znanstveni pogledi in raziskave/eksperimentalno delo z opicami po D. Haraway razkriva povedne zgodbe o silah in motivaciji pridobivanja vednosti na Zahodu. Sadizem in mizoginijo lahko opazimo šele, ko začnemo prebirati eksperimentalna poročila, načine zbijanja šal in oblikovanja diskurzivnih praks, na katerih temelji celoten eksperimentalni postopek (Bahovec, 2007: 37-38; Haraway, 1996: 137, in nasl.):

Metoda $^{17}$ znanosti torej ne more biti ne nevtralna ne objektivna; pogled znanstvenika je vedno že zainteresiran in fantazmatsko posredovan pogled. To je pogled od zgoraj [...] ne pa pogled s strani ali iz druge perspektive, ki bi omogočal konstitucijo nekega drugega objekta znanosti in neke resnice, ne da bi vodil v relativizem po meri gesla anything goes (Bahovec, 2007: 38).

Totalizaciji je treba zoperstaviti nekaj drugega: »Vsa vednost nosi odtise skupnosti, ki jo producirajo.« (Hesse-Biber in Yaiser, 2004: 45.) Ali: Every fact has a factor (Hubbard, 1998: 5). Ali: »Naj podatki govorijo sami zase, pravijo ti znanstveniki. Težava s tem seveda je, da podatki nikoli ne govorijo sami zase.« (Fox Keller, nav. po Lenzo, 1995.) ${ }^{18}$

Izhodišče, da spol vpliva na pojmovanja vednosti, spoznavajoči subjekt in spoznavajoče oziroma raziskovalne prakse oziroma da nam pogled $\mathrm{z}$ do-

17 Metodo gre tu najbrž razumeti tudi v širšem smislu, ne le kot tehniko zbiranja podatkov. Spotoma lahko omeniva še, da raba tu niha, metode se pogosto zamenjujejo z metodologijo, torej teorijo in analizo poteka raziskave (prim. tudi Schensul, v Given, 2008: 516).

${ }^{18} \mathrm{D}$. Haraway pravi, da dejstva (facts) pogosto razumejo kot izvirna, nereduktibilna vozlišča, iz katerih lahko konstruiramo zanesljivo razumevanje sveta. Skoraj naravno je zoperstavljati facts in fiction, čeprav so podobnosti med obema v zahodni kulturi in jeziku precejšnje (Haraway, 1989:3-4). 
ločene lokacije, tj. mesta, s katerega se gradita politika in vednost (Haraway, 1999: 378), lahko omogoči videti in razumeti različne vidike sveta in človekovih dejavnosti. Subjekt je izgubil svojo avtonomno in transcendentno pozicijo. Tako epistemološki subjekt konstituirajo telesa, ki opažajo, interpretirajo, merijo in vrednotijo svet iz svoje partikularne in parcialne perspektive (Prins, 1995: 356).

Kako se torej - v danem konceptualnem okviru, okviru feministične teorije - lotiti problematike dejstev, teorij in vrednotenja? Izhodiščna formulacija, ki sva ji zavezani, je: feminizem je - tako kot znanost - načrt za rekonstrukcijo občih pomenov, boj za občo vednost. Je iskanje novih zgodb in s tem jezika, ki bo omogočil novo videnje možnosti in omejitev (Haraway, 1999: 136). Je boj o tem, kaj bo veljalo za racionalne opise sveta, boj o tem, kako gledati (Haraway, 1999: 310, 315-316). Kajti racionalna vednost se ne pretvarja, da je rešitev: da je od vsepovsod in tako od nikoder, da ni obremenjena $\mathrm{z}$ interpretacijo, da je neodvisna ... »Racionalna vednost je pogajanje, ki zaznava oblast.« (King, nav. po Haraway, 1999: 313. $)^{19}$

Metodologija utegne biti problematična, ker nobena metoda ne more zagotoviti neposredne povezave med vednostjo in realnostjo. Četudi menimo, da je taka povezava možna, takoj naletimo na problem, kako te povezave misliti in postaviti. Feministke $\mathrm{v}$ splošnem štejejo celoten proces produkcije vednosti za družbeni proces, torej takega, v katerem so inherentna oblastna razmerja. Kot drugi sodobni raziskovalci družbe imajo akutne probleme pri utemeljevanju povezav med teorijo, izkustvom in realnostjo, torej med idejami o družbenem svetu, izkustvi, ki jih imajo ljudje s tem svetom, in dejanskimi družbenimi realnostmi (Ramazanoğlu, 2002: 42 in 2).

Kot pravi D. Haraway (1997: 23-24), ki vpelje v tem kontekstu pojem $\gg$ skromnega pričevalca $\ll^{20}$ - pričevalca, katerega opisi zrcalijo realnost, ki mora biti neviden, ki naseljuje potentno »neoznačeno kategorijo «, ki jo konstruirajo izjemne konvencije samonevidnosti. ${ }^{21}$ Ta oblika skromnosti plačuje tistim, ki jo uporabljajo, s kovancem epistemološke in družbene moči. To je vrednota, ki jamči, da je skromni pričevalec legitimen in avto-

\footnotetext{
${ }^{19}$ Prim. tudi: $\gg$ Znanost nam ne daje univerzalnih resnic, ki se skrivajo za vsemi naravnimi pojavi; daje pa nam modele realnosti, ki so različnih stopenj obsega in točnosti. [...] In seveda ne trdim, da so sodbe znanstvenikov v teh zadevah 'iracionalne'. Problem je prav koncept racionalnosti.« (Giere, 1999: 4.)

$20 »$ Skromni pričevalec« je povezan s knjigo S. Shapina in S. Schafferja (1985). Leviathan and the Air Pump: Hobbes, Boyle, and the Experimental Life, Princeton: Princeton University Press. ${ }^{21}$ Ta samonevidnost je specifično moderna, evropska, maskulina, znanstvena oblika vrline skromnosti (Haraway, 1997: 23).
} 
riziran ventrilokvist za objektivni svet, tu ni njegovih mnenj, predsodkov, ki bi izvirali iz njegovega utelešenja. In tako ima izredno moč, da vzpostavlja dejstva.

Skromnim ženskam pa je po drugi strani odvzeta epistemološka dejavnost (agency) in so nevidne za druge. Ta vrsta nevidnosti - izvirajoča iz telesa -, ki so jo ženske ohranile, povzroča zdrs v to, da so dojete kot »subjektivne «, da torej poročajo samo o sebi, imajo predsodke, niso objektivne. Epistemološka dejavnost (agency) gospodov (sic!) vključuje posebno vrsto transparentnosti. Rasno, spolno in razredno zaznamovane osebe morajo storiti še marsikaj, da bodo postale podobno transparentne, da bodo veljale za objektivne, skromne pričevalke sveta, in ne svojega »predsodka« ali $\gg$ posebnega interesa $\ll$. Biti objekt pogleda, ne pa $\gg$ skromen $\ll$, samoneviden vir videnja, pomeni, da ti je odvzeta dejavnost (agency) (Haraway, 1997: 32). Ta uvid - ki ga D. Haraway kasneje razdela v doktrino t. i. tehnoznanosti (prim. Haraway, 1997, Haraway, 1998: 155, in nasl.), ${ }^{22}$ reformulira pa tudi pričevanje, ki poslej pomeni omejeno prakso - lahko štejemo za pomemben prispevek k razgradnji nekaterih okorelih konceptov (kot je denimo objektivnost).

\section{Spolzki drog uporabne doktrine objektivnosti}

Ker so vprašanja »resnice« in »znanstvene veljavnosti« tu osrednjega pomena, se je treba dotakniti še nekaterih drugih delčkov v mozaiku objektivnosti, ki odločilno obeležuje t. i. zahodno znanost, hkrati pa je to tudi pomembno feministično vprašanje.

Feministično preučevanje pojma objektivnosti je morda najpomembnejši primer tega, kako so se feministke spopadle z izzivom spraviti svoje družbene opise znanstvene prakse $\mathrm{z}$ normativno nalogo prizadevati si za boljšo znanost. D. Haraway (1999: 294) pravi, da »so uradne ideologije o objektivnosti in znanstveni metodi še posebej slabi vodniki po tem, kako znanstvena vednost dejansko nastaja. Tako kot to velja za vse nas, velja tudi za znanstvenike, da je med tem, kar verjamejo ali pravijo, da verjamejo, in tem, kar zares počnejo, zelo malo ujemanja.« Feministična filozofija, ki posveča pozornost prevladovanju spolnega predsodka v dejanskih znanstvenih praksah, je uvidela, da nam je poziv k nekoč prevladujočemu idealu znanstvene objektivnosti kot vrednostne nevtralnosti le malo v pomoč, če hočemo razumeti, kako naše znanstvene prakse dejansko funkci-

\footnotetext{
22 Bistvene značilnosti feministične tehnoznanosti so denimo: demokracija, t. i. stroga objektivnost, ki je zavezana procesom človeške enakosti, sestavljena iz samokritičnih vednostnih projektov (Haraway, 1997; Haraway, 1998: 156).
} 
onirajo, in če hočemo priti do boljše znanosti. Pokazalo se je, da je bodisi treba opustiti objektivnost kot normativni ideal bodisi nekako rekonstruirati ideal in ga združiti z družbeno umeščenostjo vednosti (Grasswick in Webb, 2002: 192).

Kot pravi D. Haraway, ne potrebujemo »doktrine objektivnosti, ki obljublja transcendenco, zgodbo, ki zgubi sledi svojih posredovanj prav tam, kjer bi kdo utegnil biti za kaj odgovoren ...« (Haraway, 1999: 300). Zato - da bi nekako izšle/izšli iz zagate, $v$ katero zaidemo ob pojmu objektivnosti - predlaga pojem »umeščene vednosti«. To so vednosti, ki so samorefleksivne, kar zadeva materialne, zgodovinske in družbene pogoje, v katerih so nastale (Prins, 1995: 354). Preučevanje umeščenih vednosti poudarja načine, na katere je znanost normirana oblika »pripovedovanja zgodb «, ki poskuša priti do resnice; a ideja resnice ni tista o realnosti na sebi, temveč realnosti, ki jo producirajo človeške materialne prakse. Tako so »dejstva«, »fakti« dejansko »artefakti « znanstvenega poizvedovanja. To pa ne pomeni, da so napačni, temveč to, da so povezani s procesi človeške produkcije in potreb. Vseeno pa $\mathrm{v}$ določeni meri ohranjajo ontološko samostojnost (Janack, 2004). Kako to dobiti hkrati - to je problem feministične epistemologije, nujna multipla želja, ki je vsaj za zdaj ni mogoče artikulirati drugače kot: kako dobiti »opis radikalne zgodovinske kontingence za vse trditve o vednosti in spoznavajoče subjekte, kritično prakso za prepoznavanje naših lastnih ,semiotičnih tehnologij‘ za ustvarjanje pomenov in ne-nesmiselno zavezo zvestim opisom ,pravega' sveta « (Haraway, 1999: 299) ob zavedanju, da so vse komponente želje paradoksne in nevarne, skupaj pa kontradiktorne in nujne (ibid.: 300).

Po mnenju nekaterih je refleksija lastne umeščenosti nepotrebna, težavna ali celo nemogoča, in dokler se raziskovalec (oz. raziskovalka) drži natančno določenih postopkov za zbiranje in interpretacijo podatkov, ni nobenih težav. Drugi menijo, da je refleksija lastne umeščenosti nujna, da bi se lahko ognili predsodku. Tretja skupina pa meni, da je vednost, ki jo pridobimo z raziskovanjem, nujno utelešena, jasno pozicionirana $s$ takimi markerji, kot so rasa, spol, razred, identiteta, čas in prostor, da je pisanje o vednosti lahko samo skromna, relativna, delna, relacijska naracija, ki temelji na stališču - zgodba, ki nima večje avtoritete kot zgodbe, ki jih morda povedo udeleženci v raziskavi (Vannini, v Given, 2008: 815).

Poudarek je torej na družbeni lokaciji subjekta in družbeni konstrukciji vednosti, drugače kot $\mathrm{v}$ tradicionalnih, pozitivističnih epistemologijah, kjer je družbena pozicija pogosto nepomembna, ker je vednost preprosto 
>tam zunaj《 in čaka, da bo odkrita, neodvisno od družbenega (Hesse-Biber in Yaiser, 2004: 117). To med drugim pomeni tudi umeščenega spoznavajočega in umeščeno vednost - torej vednost, ki odseva določeno perspektivo subjekta, ki je parcialna, omejena, ne univerzalna, saj v vseh hkrati ali popolnoma v eni od epistemološko privilegiranih pozicij, ki jih strukturirajo družbeni spol, rasa, narod ipd., ni mogoče »biti «, pravi D. Haraway (1999: 308-309). Iskanje take totalne pozicije bi bilo iskanje fetišiziranega popolnega objekta opozicijske zgodovine.

Ključna praksa utemeljevanja vednosti je pozicioniranje, in to pozicioniranje implicira odgovornost (kar je ena ključnih besed te epistemologije) za prakse, ki so nam omogočene (Haraway, 1999: 308-309). Iz tega sledi, nadaljuje D. Haraway, da politika in etika utemeljujeta boje za projekte vednosti v eksaktnih, naravoslovnih, družbenih in humanističnih znanostih (ibid.).

Vse to nas je že pripeljalo $k$ še enemu očitku feministični epistemologiji, ki da goji cinično držo, ki jo Pinnick et al. (2003) razumejo kot zavračanje možnosti iskanja resnice in zavračanje tistih, ki trdijo, da to počnejo, $\mathrm{v}$ resnici pa se igrajo oblastne igre. E. Anderson v svojem zagovoru feministične epistemologije pravi, da ne gre za napad na znanost, marveč za napad na prav določeno podobo znanosti oz. znanstvenika (sic!) - ki samo razbira to, kar je vselej že prisotno, medtem ko je feministični projekt v duhu sprejemanja odgovornosti za izbire pri znanstvenih reprezentacijah (ki morajo nujno biti narejene). In poudarjanje teh izbir, njihove kontingentnosti in omejitev, ki jih prinašajo s sabo, niti zdaleč ne pomeni obtoževati znanstvenikov propagande ali nepoštenosti (Anderson).

V tem smislu je t. i. epistemologija stališč način (morda le eden izmed načinov), da ekspliciramo točko, kjer se najino raziskovanje začne. Drugače kot v kartezijanski epistemologiji, kjer spoznavajoči subjekt prihaja od nikoder, epistemski subjekt feminizma omogoča vpogled v to, od kod govori. Ko se tako identificira družbena lociranost avtor-itete in avtor-stva, ta epistemologija vzpostavi točko, s katere je mogoče preizpraševati in napraviti vidna delovanja nevključujočih diskurzov (Currie, nav. po Stoetzler in Yuval-Davis, 2002).

Ta teorija stališč ima svoje močne in šibke plati. Ne gre denimo za to, kot smo videli že zgoraj, da zavzamemo »feministično stališče « preprosto na podlagi svojega spola, in tako ne gre za redukcijo vednosti na preprost odsev družbenega temelja - ni avtomatske korelacije med družbeno lokacijo in stališčem (Stoetzler in Yuval-Davis, 2002: 316-317). 
Tule je bil sicer napravljen ovinek okoli problematike razlike med posameznikom/-ico in skupino kot enoto analize ter problematičnega razmerja feminizma do žensk na splošno. Omeniti je treba, da so feminizem pod plaščem dobronamernega univerzalizma že razkrinkali kot obliko zahodnega kulturnega imperializma, ki poskuša zajeti vse ženske v določen niz zahodnih vrednot in kategorij. ${ }^{23}$ Prav izzivi tovrstnemu feminističnemu univerzalizmu predstavljajo pomembno kontradikcijo $\mathrm{v}$ feministični politiki. Vseeno pa obstaja kritična razlika med omejenimi generalizacijami o družbenem obstoju žensk (ki temelji na specifičnih zgodovinah, izkušnjah, kulturah, lokalnostih in razmerjih) in univerzalnimi generalizacijami o »ženskah« (ki temeljijo na predhodni teoriji) (Ramazanoğlu, 2002: 6).

Kar pa zadeva podmeno, da vse ženske mislijo enako, da je feministično enako žensko (oboje pogosto v skladu s seksističnimi stereotipi) in da obstaja neka ženska kognicija - zaradi kar neverjetne vztrajnosti tega enačenja in poenostavljanja je tu nemara treba vseeno ponoviti, da to ni izhodišče feministične epistemologije, kot jo razumeva tukaj. Preseči je treba enačenje ženskega in feminističnega ter dojemanje feminizma kot domnevno združujočega dejavnika vseh žensk. To stališče dosežemo in se z njim ne rodimo (kar predpostavlja tudi kritičen razmislek o izkušnjah in povezavah s širšimi družbenimi in političnimi strukturami). Zahteva po družbeni marginalizaciji, ki prinese epistemske privilegije, pa je lahko po drugi strani odvisna tudi koncepta identitete, ki ga je treba utemeljiti v skupnosti izkustva marginaliziranih skupin. Vendar pa nimamo »osebnega dostopa« do doživetih diskurzivnih strategij (Haraway, 1997: 198). Hkrati pa je to še posebej pomemben uvid, $s$ katerim lahko »dopolnimo « razmišljanje o teoriji stališč: če trdimo, da predstavljajo življenja žensk boljšo izhodiščno točko za razmislek o spolnih sistemih, to ni isto, kot če bi trdili, da so njihova lastna življenja taka najboljša izhodiščna točka (Harding, nav. po Stoetzler in Yuval-Davis, 2002: 319).

$\mathrm{Z}$ drugimi besedami, gre za $\gg$ gledanje od spodaj «, $\gg \mathrm{z}$ obrobij «, »iz globin «. Obstaja dober razlog, pravi D. Haraway, da menimo, da je pogled boljši s spodnjega dela bleščečih prostorov oblastnikov. A gledanja od spodaj se ni lahko naučiti, obstaja nevarnost romantiziranja in prisvajanja pogleda manj vplivnih. Stališča podvrženih niso »nedolžne « pozicije, preferenco dobijo zato, ker je načeloma najmanj verjetno, da bodo dopustila zanikanje kritičnega in interpretativnega jedra vse vednosti. Ta stališča so al-

${ }^{23}$ Temeljno delo, ki problematizira »feministični univerzalizem «, je nemara Under Western Eyes. Feminist Scholarship and Colonial Discourses Ch. T. Mohanty iz leta 1986, ki je izpostavilo diskurzivno konstrukcijo »ženske Tretjega sveta« kot hegemono entiteto. 
ternativa načinom zanikanja s potlačenjem in pozabljanjem, ko trdimo, da nismo nikjer in da vidimo vsestransko (Haraway, 1999: 305). Epistemološko privilegirana izhodišča raziskovanja ne zagotavljajo, da si lahko raziskovalka pripiše več objektivnosti; gre zgolj za temelje, ki zagotavljajo potrebno, ne pa zadostno izhodišče za maksimiranje objektivnosti.

Lokacija ženskega spola (gender) je potemtakem vir za vzpostavitev feminističnega stališča, ki lahko odpre nova vprašanja. Družbene identitete so lahko motivacija - ali pa tudi ne - za razvijanje kritične zavesti do ustaljenih mnenj in vrednot. To pa ne pomeni, da izkustvo te identitete že samo po sebi prinaša vednost ali celo privilegirano vednost, marveč da vsebuje vire, iz katerih je s kritično in teoretsko refleksijo mogoče razviti nove vednosti.

V izogib nesporazumom, ki so pri razumevanju pojma objektivnosti pogosti, še enkrat poudarimo, prvič, da pri teoriji stališč ne gre za empiricistični poziv zatiranim, ampak za kognitivno in politično orodje za dosego adekvatnejše vednosti, ki jo merimo po neesencialističnih, historično kontingentnih in umeščenih merilih (Haraway, 1997: 198). Ta pojem je bil razvit prav kot kontrast epistemološko naivnemu pojmu ženskega gledišča/ stališča, saj gre tu za projekt, ne za podedovano, treba ga je doseči, ni kar dan. ${ }^{24}$ In drugič, da teorija stališč omejuje obseg svojih trditev, da poskuša generirati vednosti, ki koristijo marginaliziranim pri identifikaciji problemov v sociostrukturnem okviru. ${ }^{25}$ Treba je tudi vztrajati pri

nemožnosti »identitetne« politike in epistemologij za gledanje s stališč podrejenih, da bi dobro videli. Ne moremo » biti« celica ali molekula - ali ženska, kolonizirani, delavec in tako naprej -, če nameravamo s teh pozicij gledati kritično. »Biti < je veliko bolj problematično in kontingentno. Prav tako se ni mogoče namestiti na katero koli izhodiščno točko, ne da bi bili za ta premik odgovorni. Videnje je vedno vprašanje moči gledanja (Haraway, 1999: 307). ${ }^{26}$

Tako je treba pri zavrnitvi kritik (prej napačnem razumevanju) o privilegirani vednosti podrejenih skupin izpostaviti tezo o epistemskem privi-

${ }^{24}$ Tako N. Hartsock, nav. po Stoetzler in Yuval-Davis, 2002. Toda D. Haraway na drugem mestu (1998: 160) pravi, da je lokacija kompleksna konstrukcija in hkrati podedovano, kar morda kaže na nedodelanost ali vsaj ohlapnost koncepta.

${ }^{25} \mathrm{Ne}$ trdi, kot ji na primer skuša pripisati R. Klee (v Pinnick et al., 2003: 312, in nasl.), da bi lahko bila »feministična kognicija « privilegirana pri generiranju vednosti iz fizike ali kemije (nav. po Anderson). Kleejev podnaslov si res zasluži, da ga navedemo: The Ultimate Feminist Epistemological Fantasy.

${ }^{26}$ In še: »Videnje zahteva instrumente videnja; optika je politika pozicioniranja.« (Haraway, 1999: 309.) 
legiju, po kateri naj bi bilo verjetneje, da neprivilegirani družbeni položaji generirajo perspektive, ki so manj pristrane, kot perspektive, ki jih generirajo drugi družbeni položaji. Ta teza torej ni enaka tezi o avtomatskem epistemskem privilegiju, ki predpostavlja, da ženske nekatere stvari vedo preprosto zaradi tega, ker so na določeni družbeni poziciji (Rolin, 2006: 125 in 136).

Tako preferirano pozicioniranje ni naklonjeno relativizmu in ne totalizirajočim trditvam o znanstveni avtoriteti. Relativizem ni alternativa totalizaciji (in enemu samemu pogledu). Alternativa so parcialne, lokalizabilne (kar ne pomeni fiksno locirane v reificiranem telesu, ne ženskem ne katerem koli drugem) in kritične vednosti (Haraway, 1999: 306 in 311). Refleksija pokaže, da je relativizem zrcalni dvojček totalizacije v ideologijah objektivnosti - oba onemogočata, da bi dobro videli, oba sta »božja trika« (Haraway, 1999: 306). Trditev, da ni mogoče legitimno soditi o nobeni kognitivni ustreznosti, je zelo blizu trditvi, da je vednost mogoče producirati samo od »nikoder « (Harding, 1991: 153). ${ }^{27}$ In končno, oba spregledujeta, celo zanikata lociranje in parcialno perspektivo.

\section{Pogled od nikoder in pogled od povsod: relativizem in izkustvo}

Začnimo z očitkom o relativizmu, ki je v ideologijah objektivnosti na neki način podoben univerzalnemu pogledu tradicionalne epistemologije - oba obljubljata pogled od povsod in nikoder, in to v enakem in popolnem obsegu. Feministične epistemologinje naj bi se zaradi svoje kratkovidnosti zavzemale prav za tisto, kar po drugi strani obsojajo, torej za vrednote, ki so zatiralske (tudi) do žensk, in za neznanstvene vednostne sisteme. Ta trditev je netočna, saj cilj feministične epistemologije ni odprava zahodne znanosti, ampak, denimo, njena izboljšava. Feministične epistemologinje, zlasti teoretičarke stališč, lokalnih vrednot ne sprejemajo nekritično kot danosti, marveč uveljavljene vrednote »merijo《 ob izkušnjah zatiranih (Anderson).

Tu se pojavi dilema spričo multiplih, delnih, umeščenih vednosti: kako vrednotiti te delne poglede, ki niso vsi enaki, nekateri so na ta način »resničnejši« od drugih. Razlike med delnimi vednostmi so pomembne, saj

\footnotetext{
${ }^{27} \mathrm{~S}$. Harding uvede ločevanje med historičnim oziroma kulturnim relativizmom (kar je v neki kulturi razumna trditev, v drugi ni) in mnenjskim oziroma epistemološkim relativizmom (ta zanika možnost razumnih meril pri odločanju med različnimi trditvami) (1999: 139, 152, in nasl.). Epistemologija stališč poziva k priznanju prvega, ne pa seveda drugega, ki je zrcalna verzija t. i. šibke objektivnosti. To ločevanje je morda res sporno ali pa vsaj v tem okviru neproduktivno (prim. Klein, 1993: 64).
} 
kar vsaka delna perspektiva ni ustrezna (kar bi sicer vodilo v sporni relativizem po načelu »vse je sprejemljivo«). Sicer D. Haraway zatrjuje, da so nekatere zgodbe »boljše « kot druge, ne specificira pa kakih splošnih meril za ugotavljanje, kaj konstituira »resničnejše« ali »boljše« (Ramazanoğlu, 2002: 76-77).

Kljub določeni problematičnosti take zastavitve epistemologije je mogoče trditi, da je boljša, »ne ker je resničnejša, ampak ker odkrito priznava svojo parcialnost in se ne pretvarja, da ponuja končno modrost in objektivno resnico « (Felski, 2000: 198). ${ }^{28}$ Kot pravi D. Haraway, morajo feministke »vztrajati pri boljšem opisovanju sveta; ni namreč dovolj, da pokažejo radikalno zgodovinsko kontingenco in načine konstruiranja vseh stvari« (Haraway, 1999: 299) - to je v končni fazi odgovornost (te) epistemologije.

D. Haraway opozarja na $\gg$ dva pola mamljive dihotomije «: $\gg$ slaba $\ll$ (androcentrična) znanost proti »dobri« (feministični), in govori o »spolzkem drogu doktrine objektivnosti« oziroma o njegovih dveh koncih, ki sta lahko tudi konstruktivizem, v okviru katerega sta resnica in objektivnost del jezika in oblastnih iger znanosti, ter empirizem, s pozicije katerega je znanstvene izjave mogoče kritizirati zaradi moškega predsodka (Haraway, 1999, 301; Prins, 1995: 353):

V svojih prizadevanjih, da bi splezale po spolzkem drogu do uporabne doktrine objektivnosti, smo se jaz in večina drugih feministk v razpravah o objektivnosti izmenično ali celo hkrati držale obeh koncev dihotomije, ki jo Hardingova opisuje kot projekte nasledstvene znanosti proti postmodernim opisom razlike, in to sem opisala v tem poglavju kot radikalni konstruktivizem proti feminističnemu kritičnemu empirizmu. Seveda je težko plezati, če se držite obeh koncev droga, hkratiali izmenično.

D. Haraway ne preferira nobene opcije oz. vidi (upravičene) težave pri obeh. Konstruktivizem se nagiba k relativizmu, ki je »način, kako nismo nikjer, a hkrati trdimo, da smo povsod enako « (Haraway, 1999: 306), empirizem pa po drugi strani predpostavlja univerzalističen pogled, ki ga je mogoče opisati kot »biti povsod, hkrati pa zanikati potrebo, da bi bili kjer koli« (Prins, 1995: 353). Ne prvi in ne drugi pa ni lokalizabilen in zato ju ni mogoče poklicati na odgovornost - umanjka torej ena od bistvenih zahtev »nove« oziroma uporabne doktrine objektivnosti, ki je odgovornost.

Smisel plezanja na drog je produkcija veljavne vednosti o ospoljenem družbenem življenju. $Z$ eno roko se feministična raziskovalka drži dedišči-

${ }^{28} \mathrm{Na}$ tem mestu so spregledani različni filozofski tokovi, ki prav tako opozarjajo pred absoluti. 
ne zavezanosti znanosti in razumu, da bi priskrbela vednost o tem, kakšna so dejansko ospoljena življenja, in da bi uspešno tekmovala s patriarhalno vednostjo. Feministke lahko uporabijo »izsiljive, zanesljive opise stvari, ki jih ni mogoče reducirati na premike oblasti in agonistične statusne igre retorike ali na scientistično, pozitivistično znanost« (Haraway, 1999: 300). $\mathrm{Z}$ drugo roko pa noče izpustiti relativistične trditve, da so »spoznavajoča feministka«, »realnost «, ki jo »odkriva«, in »resnice«, ki jih pripoveduje, vse družbeno konstituirane v določenih situacijah, kulturah in načinih mišljenja. Feministke se težko popolnoma ognejo potegu tako relativizma kot realnosti, zato pogosto zdrsnejo ali se čutijo zavezane, da izberejo eno ali drugo.

D. Haraway predlaga, da se opustijo poizkusi povezovati ideje, izkustvo in resnico na ta način (ker se pač ne da plezati na drog in se hkrati držati obeh koncev) in da se namesto tega raziskuje pojem delnega videnja in umeščenih vednosti.

Spolzek drog razjasnjuje posebne težave, ki se odprejo, ko trdimo, da je feministična vednost boljša kot denimo patriarhalna, in ko razsojamo, da so nekateri feministični prispevki (accounts) boljši kot drugi. Drugič, s tem lahko tudi pojasnimo, zakaj se feministični pristopi k metodologiji razlikujejo. Tretjič, izpostavi kontradikcije moderne metodologije, ki jim feministične teoretičarke stališč poskušajo pobegniti (Ramazanoğlu, 2002: 61).

Iskanje resnice je spolzko, ker ni absolutnih rešitev. Vse sodobno družbeno raziskovanje, ki vključuje empirično preučevanje družbenega sveta kot načina povezovanja vednosti in realnosti, drsi po tem metodološkem drogu, ne glede na to, ali se raziskovalci oz. raziskovalke tega zavedajo ali ne (Ramazanoğlu, 2002: 61-62).

Po drugi strani pa so se $\mathrm{v}$ nekaterih tokovih feminizma kot odziv na to, kar je R. Felski imenovala dekonstrukcijski skepticizem (Felski, 2000: 1999), oblikovale zahteve po »strateškem esencializmu«, ki bi potrdil, vsaj začasno in zasilno, koherentnost ženske kot kategorije. Izkustvo je tu s svojimi vedno problematičnimi pomeni še posebej odločilno. Kako je mogoče misliti kolektivno izkustvo, ki je zlasti težaven in pogosto zelo zavajajoč pojem?

Sporni so, kot kaže, pogoji artikuliranja izkustva. Izkustvo, kot opozarja tudi D. Haraway, ne nastopi pred družbenimi okoliščinami, diskurzi in drugimi praksami, to ni nekaj, kar bi obstajalo v obliki predhodne- 
ga vira, ki ga je treba zgolj prevesti v nekakšen opis. ${ }^{29} \mathrm{D}$. Haraway izkustva ne postavlja neposredno kot epistemološko pravilnega, marveč kot nameren konstrukt, kot artefakt velikega pomena (ki je tudi potencialno imperialističen, saj je $\mathrm{v}$ feminizmu pogosto in dolgo obveljala le ene vrste izkušnja - izkušnja belih, zahodnih feministk), in hkrati opozarja, da si ne smemo dovoliti, »da bi izkustvo razumele kot neskončno pluralen in neoporečen pojav; kot nekaj samoumevnega in ob pogledu vase $\mathrm{z}$ lahkoto dosegljivega; kot nekaj, kar pripada samo nam ali samo eni skupini« (Haraway, 1999: 179 in 184).

Če pa bi to pomenilo postavitev »osebnega izkustva « kot zanesljive informacije o svetu, potem je resno spregledan potencial $\gg$ samosubverzivne samorefleksije« (Felman, nav. po Penley, v Bahovec, 1992: 267) - gre za spregled interpretacije tega izkustva, ki se izvija skozi govorjenje/pripovedovanje, in premočno stavo na empirizem. »Doživetje« ali »izkustvo《 namreč ne pomeni »pojavne realnosti, ki bi jo bilo treba prek govorice priklicati v spomin in zavest. Govorica, ki jo analiziranec uporablja za podajanje in poročanje o doživetjih, je prvi material analize, ne pa doživetje 'samo'«(Ibid., 267.) ${ }^{30}$

Kaj pravzaprav sestavlja izkustvo - dogodek ali interpretacija dogodka? Izkustvo ni resnica, ki bi predhodila kulturno podanim reprezentacijam izkustva, ampak ga te reprezentacije posredujejo. »Svet, kot ga zaznavamo, je produkt družbenih in zgodovinskih sil, a izkustvo stremi k temu, da bi se soočilo z zgodovinsko eksistenco kot z golim dejstvom.« (Stone-Mediatore, v Narayan in Harding, 2000: 111-112.) Izkustvo nam konec koncev lahko tudi laže, ko nam zgodovinsko konstruirane družbene ureditve predstavlja kot naravne (Harding, nav. po ibid.).

Nedodelano izhodišče bi bilo tudi zavračanje teorije v prid izkustva ali zoperstavljanje enega in drugega: izkustvo kot resnično in pomembno proti teoriji kot »abstraktni« in odtujeni od materialnosti življenj žensk. Recimo, da teorija ni le intelektualno zanimiva, marveč bistvenega pomena za feminizem. Teorija ni le akademska vaja v slogu ali spisek za ženske pomembnih vprašanj, marveč temelj za razumevanje različnih področij našega življenja (Bunch, nav. po Mulinari in Sandell, 1999: 295).

\footnotetext{
${ }^{29} \mathrm{~V}$ tem smislu ne drži povsem, kot piše denimo E. D. Bahovec, da feminizem epistemološko zvede problem osebnega izkustva na nekaj neposredno dostopnega in transparentnega, etično pa na problem žrtve, ki se kaže kot feministično pajdaštvo (Bahovec, 2007: 44-45).

${ }^{30}$ Gotovo ne moremo v popolnosti enačiti doživetja v analizi in doživetja v feminizmu, če temu tako rečemo. Je pa pri refleksiji doživetja (ne pa tudi njegovem razvrednotenju) smiselno imeti v mislih zadržke do »resničnosti« dogodka in pomen fantazem.
} 
Če ponovimo, izkustvo ne more biti kategorija, ki bi jo presojali po kriteriju epistemološke pravilnosti, od tod tudi kritika izkustva kot neposredovanega, kot nereprezentiranega, hkrati pa apriorna zavrnitev izkustva nemara pomeni izgubiti kategorijo žensk, kategorijo, ki se zdi nujna vsaj v aktualnih, vsakodnevnih zahtevah in spopadih. ${ }^{31}$

\section{$(\mathrm{Ne})$ ved nosti in taksonomija (ne)vednosti}

Za izhodišče sva tu vzeli delo C. Penley, ki feminizem misli skupaj s psihoanalizo kot feminizem in psihoanalizo. Analiza C. Penley je v prvi vrsti namenjena preučevanju feminizma in psihoanalize preko - kot pravi sama - ovinka, ki ga predstavlja razmerje feminizma in psihoanalize do vednosti in avtoritete, do etike poučevanja (Penley, v Bahovec, 1992: 256-257). C. Penley sklepa - če smo že pri tem -, da ne gre za vprašanje, kaj obljubljata ali ponujata drug drugemu, marveč kako »drug drugega pozivata k poučevanju tako razmerja do vednosti in avtoritete kot tudi do pojmovanja identitete in spolne razlike.« (Ibid.: 73.)

$\mathrm{Z}$ avtoriteto se feministična pedagogika spopade $\mathrm{z}$ uvedbo specifičnih pedagoških prijemov, ki merijo na njeno oslabitev ali odpravo. To so denimo: krožna razporeditev stolov v učilnici, naslavljanje vseh udeleženih z imeni ipd. Bistveno vprašanje ob tem je seveda, ali s tem ne izgubimo tudi moči transfernega odnosa, moči učitelja, ki v polni meri sprejme »ogrinjalo subjekta, ki se zanj predpostavlja, da ve« (Penley, v Bahovec, 1992: 258). ${ }^{32}$ Problem vednosti je še razsežnejši, po eni strani povezan $z$ dvoumnim mestom vednosti, ${ }^{33}$ po drugi z zahtevami po drugačni epistemologiji, ki bo, med drugim, »opravila« z dihotomijo subjekta in objekta.

Tako vključujeva tudi koncept »epistemologij nevednosti« (epistemologies of ignorance) in preverjava načine, na katere je nevednost bolj kot vednost učinek študij seksualnosti in šolskih izobraževalnih programov o spolnosti. Če hočemo namreč razumeti kompleksne prakse produkcije vednosti in različnost dejavnikov, ki razložijo, zakaj je nekaj znano, moramo

\footnotetext{
${ }^{31}$ Hkrati sva že poskušali nakazati, v čem je spornost in v čem aktualnost pojma »izkustvo《, tako za feministično teorijo in ženske študije kot tudi za povezavo »feminizma in pedagogike« ali feministične pedagogike, ki si - v grobem - prizadeva za egalitarna razmerja v razredu, pod vprašaj postavlja vlogo in avtoriteto učitelja (ali učiteljice), osredotoča se na osebne izkušnje oziroma jih uporablja pri konstrukciji vednosti (nav. po Jackson, 1997: 458). S tem poskuša vzpostaviti drugačno naravo socialnih razmerij, ki konstruirajo spoznavajoči subjekt.

${ }^{32}$ Transfer je oblika identifikacije in učiteljevo poglavitno pedagoško orodje, opustitev te imaginarne pozicije, pravi C. Penley, bi pomenila izgubo tega orodja (Penley, v Bahovec, 1992: 257 in 258). Ob strani sedajle puščava pomen transferja $\mathrm{v}$ psihoanalizi oziroma pomen za analiziranca. ${ }^{33} \mathrm{Na}$ kratko: vednost ne $\mathrm{v}$ analitični situaciji ne $\mathrm{v}$ feminizmu ni umestljiva na točno določeno mesto (Penley, v Bahovec, 1992: 265, in nasl.).
} 
razumeti tudi prakse, ki razložijo neznano, tj. naš manko vednosti o določenem pojavu, ali v nekaterih primerih prakse, ki vodijo v skupinsko razučenje (unlearning) nečesa, kar je bilo nekoč v domeni vednosti (Tuana, nav. po Tuana, 2006: 2).

Spol označuje vzorec razlike v izkustvu v kulturno specifični družbeni skupini, ker so bistvene značilnosti vsake spolne identitete odvisne od kulturnih praks, kot pravi L. Alcoff v svojem razčlenjevanju epistemologij nevednosti (v Sullivan in Tuana, 2007: 43, in nasl.). A nevednost, kot jo razumeva tukaj in kot jo med drugim zastavi L. Alcoff, ni manko, denimo manko v motivaciji ali izkustvu kot rezultatu družbene lokacije, ampak sama po sebi substancialna epistemska praksa (in ne praksa, ki bi na primer kazala zgolj na brezbrižnost, več o tem spodaj), ki diferencira dominantno skupino (Alcoff, v Sullivan in Tuana, 2007: 39-40, 47-48). Med vednostjo in nevednostjo ni simetrije, nevednost ni negativni pol vednosti.

Nevednost je v domeni znanosti tipično predstavljena kot vrzel v vednosti, kot nekaj, $\operatorname{kar}\left(\mathrm{še}_{\mathrm{e}}\right)$ ne vemo, pravi N. Tuana. A pogoj vednosti ni vedno tako preprost. Tako kot mora vsak adekvaten opis vednosti vključevati več kot le resnico tistega dela vednosti (denimo analizo tega, zakaj so tisti, ki so na pozicijah avtoritete, sprejeli določeno verjetje kot resnico), tako je tudi nevednost na polju produkcije vednosti kompleksnejša in ne le nekaj, česar še ne vemo (Tuana, 2006: 3).

Tako konceptualizirana nevednost torej ni preprosto manko, vrzel $\mathrm{v}$ znanju, epistemski spregled, ki ga lahko hitro popravimo, takoj ko ga opazimo, in ki se pogosto zdi naključni by-product omejenega časa in virov, ki jih imamo na voljo za spoznavanje našega sveta. Včasih ne gre za naključni rezultat spregleda - to, česar ne vemo, ni le vrzel v našem znanju (Sullivan in Tuana, v Sullivan in Tuana, 2007: 1-2). Taka nevednost je pogosto konstruirana, vzdrževana in širjena v svoji povezanosti z avtoriteto - transferjem spoznavanja, dvoma, zaupanja, utišanja in negotovosti. Pojavlja se lahko na različne načine: včasih tisti v središču marginaliziranim ne pustijo vedeti, včasih sami ne vedo za nepravičnost in krivičnost, včasih so ta »neznanja zavestno sproducirana, včasih pa nezavedno generirana in vzdrževana (ibid.). Koncept »epistemologije nevednosti« sva že implicirali v dekonstrukciji (levega) neoliberalnega spoznavanja proliferacije pornografije $\mathrm{v}$ množične medije/nove medije, tj. v dekonstrukciji dominantnega pojmovanja pornografije kot pornografskega »ne misliti« (Šribar, 2006).

N. Tuana vpelje koncept umeščenih vednosti, ki sva ga reflektirali zgoraj, in ga dopolni: tudi nevednost je tako kot vednost umeščena. In med- 
tem ko D. Haraway pravi, da »potrebujemo [...] tudi zmožnost delnega prevajanja vednosti med zelo različnimi - in oblastno diferenciranimi skupnostmi (Haraway, 1999: 300), naredi N. Tuana obrat in doda, da »potrebujemo zmožnost delnega prevajanja nevednosti med zelo različnimi - in oblastno diferenciranimi - skupnostmi (Tuana, 2006: 3, 4, in nasl.). Njena - tudi po njenih besedah delna in nepopolna - taksonomija izhaja iz feminističnega dela $\mathrm{z}$ (ne)vednostjo, povezano z ženskimi telesi, ${ }^{34}$ področjem torej, ki je še posebej povezano $z$ dominantnimi teorijami vednosti, ki imajo tudi politiko in kjer je veliko prizadevanja posvečeno ohranjanju dominantnosti. V nadaljevanju je na kratko predstavljena ta taksonomija, ki je tu še posebej relevantna, glede na to, da gre za temo, povezano $s$ konceptom telesa in zdravja. ${ }^{35}$

Vemo, da ne vemo, ampak ni nam mar (- to ni povezano $z$ našimi trenutnimi interesi).

Splošni topos je, da znanstveniki ne iščejo resnice brezciljno, ampak se presodi, da je določena tema vredna raziskovanja iz različnih razlogov, in nevednost je včasih rezultat konfiguracije interesov. Npr.: veliko več kontracepcijskih sredstev je bilo razvitih za ženske kot za moške, v skladu z interesom farmacije, ki je presodila, da raziskave v smeri moške hormonalne kontracepcije ne bi bile donosne. ${ }^{36}$ Pri tem primeru vemo, da ne vemo, možnost moške hormonalne kontracepcije ni bila spregledana, gre le za to, da ta vednost ni pomembna, kot trdijo tisti, ki bi tako raziskavo sprožili (in seveda financirali).

Niti vemo ne, da ne vemo (- trenutni interesi/vednost blokirajo tako vednost).

To kategorijo je težko identificirati brez poprejšnjega vpogleda, hkrati pa potem, ko je bila identificirana, lahko zdrsne v prejšnjo kategorijo. Npr.: opisi moških in ženskih spolnih organov se razlikujejo - medicinska vednost se osredotoča na reproduktivne sisteme, zunanje ženske genitalije pa pušča ob strani pri opisu ženske anatomije.

\footnotetext{
${ }^{34}$ Zlasti The Boston Women's Health Collective.

${ }^{35}$ Ta taksonomija je obširno razdelana v Tuana, 2006: 4, in nasl., povzemava samo njen okvir in nekatere primere.

${ }^{36}$ Arditti, R. (1977). Have You Ever Wondered about the Male Pill?. V: Dreifus, C. (ur.). Seizing Our Bodies. The Politics of Women's Health. New York: Vintage Books (nav. po Tuana, 2006: 4). R. Arditti pravi, da je bila v ozadju skrb zaradi zmanjšanega libida, ki pri ženski kontracepciji (skupaj s še drugimi stranskimi učinki) ni bila nikoli tako izpostavljena.
} 
Nočejo, da bi vedeli (- nevednost določenih skupin se goji sistematično).

Npr.: zaradi poslovnih interesov so farmacevtske družbe in pooblaščeni organi prikrivali možne stranske učinke oralne kontracepcije. ${ }^{37}$

\section{Hotena nevednost (- ne vedo in nočejo vedeti).}

Ta oblika nevednosti zahteva aktivno produkcijo in ohranjanje. Npr.: področje, na katerem je želja ne vedeti izjemno močna, je incest. L. Sacco ${ }^{38}$ denimo piše, da je bilo zanikanje zmožnosti incesta pri belih moških srednjega in višjega sloja v Združenih državah Amerike tako močno, da so zdravstveni delavci raje modificirali svoje ugotovitve, kot priznali to, česar niso hoteli vedeti - visoko število primerov gonoreje pri pet do devet let starih deklicah so pripisali ne incestu, marveč straniščnim školjkam ali terapevtom in feministkam, ki so povzročili norijo krivih obtožb.

Nevednost, ki jo producira konstrukcija epistemsko manj privilegiranih identitet.

Žrtve incesta pogosto štejejo za epistemsko nekredibilne, konstruirane so kot dovzetne za sugestije, kot lahkoverne ali maščevalne. V teh primerih torej niso samo dejstva, dogodki, prakse, ki niso znane, marveč so tudi skupine in posamezniki dojeti kot »nevedni«. Dojeti so kot nevredni zaupanja, zaupanje pa je ključ do tega, da štejejo nekoga za vedočega. Zaupanje je »pogoj delujočega članstva v epistemski skupnosti«.39 Merila epistemske kredibilnosti pa so prepredena s sistemi opresije oz. presodkov.

Ljubeča nevednost (- sprejemajo, česar ne morejo vedeti).

Primeri nevednosti so lahko tudi rezultat interesov in praks, ki niso povezani z nepravičnostmi ali neenakostmi. Taka kategorija nevednosti je to, kar presega naše zmožnosti - pripoznanje, da obstajajo modalitete bivanja, ki presegajo naše in jih ne moremo polno razumeti.

$S$ to - seveda delno in nepopolno - tipologijo nevednosti sva želeli v grobem začrtati problematiko: vednost proti nevednosti, ki ni zgolj epistemski spregled, ${ }^{40}$ nevednost kot strukturno stanje, ki nam omogoči na novo premisliti pojme, kot sta »resnica«, »razum « ipd. (Alcoff, v Sullivan in Tu-

\footnotetext{
${ }^{37}$ Seaman, B. (1969). The Doctors' Case Against the Pill. New York: P. H. Wyden (nav. po Tuana, 2006: 9).

${ }^{38}$ Sacco, L. (2002). Sanitized for Your Protection: Medical Discourse and the Denial of Incest in the United States, 1890-1940. Journal of Women's History, 14/3, 80-104 (nav. po Tuana, 2006: 12).

${ }^{39}$ Code, L. (1987). Epistemic Responsibility. Hanover: University Press of New England (nav. po Tuana, 2006: 13).

40 Široko in produktivno polje tematizacije nevednosti odpira psihoanaliza, ki nevednost razume kot radikalen pogoj vednosti, integralni del same strukture vednosti. »Človeška vednost je,« kot piše Sh. Felman (v Bahovec, 1992: 236, in nasl.), »tako po definiciji netotalizabilna, izključuje vsako možnost totalizacije tega, kar ve, ali izkoreninjenja lastne nevednosti.«
} 
ana, 2007: 57), nisva pa tematizirali alternativ v smislu rekonstrucijskih projektov in $\mathrm{v}$ tem smislu puščava polje odprto za nadaljnje intervencije. Analiza nevednosti bo poleg analize splošnih pogojev epistemske umeščenosti, epistemskih virov, ki so različno razporejeni po družbenih lokacijah, stukturnih kontekstov, ki organizirajo in reproducirajo zatiranje, morala vključiti, kot piše L. Alcoff (v Sullivan in Tuana, 2007: 57), tudi potrebo, da se epistemologija zave svoje lokacije v ekonomskem sistemu in je do nje kritična.

\section{Vrednotenja epistemologije}

Nujna multipla želja feministične epistemologije, o kateri govori D. Haraway (1999: 299), tj. kako združiti opis radikalne zgodovinske kontingence za vse trditve o vednosti z ne-nesmiselno zavezo zvestim opisom $\gg$ pravega « sveta, ostaja in je še vedno lahko vodilo razmisleka feministične epistemologije in njenega vrednotenja. Čeprav je od izida dela Opice, kiborgi in ženske, ki je temeljnega pomena za feministično teorijo in feministično epistemologijo, minilo že skoraj dvajset let (Haraway 1999, v originalu je knjiga izšla 1991) in se je vmes zagotovo zvrstilo veliko prizadevanj spopasti se s to »nujno, multiplo željo «, kakor tudi utemeljenih in neutemeljenih kritik, ostaja ta želja aktualna.

Očitki feministični epistemologiji (ki ni, ponoviva, monolitna skupinska perspektiva), kot so politična korektnost, relativizem, zavračanje objektivnosti ali možnosti ustreznega opisa sveta, so bili že večkrat obdelani in tudi zavrnjeni, a v razpravah nenaklonjenih kritikov še vedno pogosto vzniknejo kot enačenje feministične epistemologije zgolj in samo z iskanjem in razkrinkavanjem seksizma bodisi pri znanstvenikih bodisi v sami znanosti (ki ga sicer ni tako težko najti) - to je res poenostavitev misli V. Woolf (npr. Klein, 1993: 57, ki to misel označi za bojni krik feminističnih filozofinj znanosti). Gre preprosto za uveljavljanje izhodišča, da »politični in družbeni interesi niso ,dodatki' sicer transcendentalni znanosti, ki je notranje indiferentna do človeške družbe; znanstvena prepričanja, prakse, institucije, zgodovine in problematika so in so vedno bili konstituirani skozi sodobne politične in družbene projekte« (Harding, 1991: 145). Ali (še preprosteje): pogosto že sama vključitev perspektive življenja žensk (to besedno zvezo uporablja $S$. Harding) naredi nenavadno to, kar se je dotlej zdelo znano in samoumevno (Harding, 1991: 150). ${ }^{41}$

\footnotetext{
${ }^{41}$ S. Harding je zasnovala koncept stroge objektivnosti (strong objectivity) kot izhajanje iz življenja žensk (Harding, 1991: 150). Potem pa je razširila ta pojem na izhajanje iz življenja »drugih«, ki zasedajo neprivilegirane družbene lokacije. Ob tej spremembi je treba omeniti, da S. Harding sedaj pravi, da doseženo stališče ni omejeno na tiste, ki zasedajo družbeno neprivilegirane lokacije, ampak ga lahko dosežejo tudi tisti/tiste raziskovalke/-ci, ki so pozorni do življenja
} 
Tega ne razumeti preveč esencialistično (zgoraj sva že govorili o »ženskem « in »feminističnem «), pač pa kot izhodiščno točko ali obrat neke ustaljene perspektive. Kot piše E. D. Bahovec v zvezi z epistemološkim bojem feminizma: najprej spopad s kategorijo samoumevnega, z vsem, kar se kaže kot dano, naravno in nespremenljivo: »z vsem, kar se zgolj kaže in je zato nekaj zavajajočega«. Zato je treba problemu ničelne stopnje - ki je, kot rečeno, iskanje ženskih imen in njihovo »vpisovanje « v zgodovino -, problemu odsotnosti njegove epistemologizacije dodati še nujnost feminističnega spopada z zdravim razumom (Bahovec, 2007: 35-36).

Problem multiplih, delnih, kontingentnih in umeščenih vednosti je treba rešiti na tak ali drugačen način in D. Haraway skoči s spolzkega droga doktrine objektivnosti (Haraway, 1999: 301) tako, da opusti privilegirano vednost $\mathrm{v}$ prid delnih pogledov in družbeno umeščenih vednosti, a je še vedno ujeta v dilemo, da delni pogledi niso vsi enaki, da so nekateri »resničnejši« od drugih. Tako pusti merila $\gg z n a n o s t i \ll$ ali veljavnosti prav tako politično in epistemološko problematična. Vseeno pa se odmika od realističnega pojma stališčc, ko trdi, da ljudje sicer lahko gledajo s podrejenih pozicij, to pa ne pomeni, da so ti pogledi nujno zanesljivi ali nedolžni: »Pozicioniranja podvrženih niso izvzeta iz kritičnega razmisleka, dekodiranja, dekonstrukcije in interpretacije.« (Haraway, 1999: 305.) »Podreditev ni temelj za ontologijo [...] ni neposrednega pogleda s stališča podvrženih.« (Haraway, 1999: 309.) Prakse pridobivanja vednosti nasploh nenehno generirajo objekte, vprašanja in izkušnje, ki so zelo realni, ki imajo etične in politične implikacije, zato jih ne moremo šteti za nedolžne (Prins, 1995: 356).

Gledanje od spodaj ni rešitev, ker še vedno pušča feministke s problemom razbiranja (making sense) tega, kar je videti (kot rečeno, D. Haraway zavrača tako realizem kot tudi relativizem). Razlike med delnimi vednostmi so pomembne - ker vsaka delna perspektiva ne zadošča. D. Haraway poskuša trditi, da so nekatere oblastne zgodbe »boljše « kot druge, ne specificira pa kakih splošnih meril za ugotavljanje, kaj konstituira »resničnejše « ali »boljše«. To kaže na napetost glede veljavnosti in med epistemologijo in politiko (Ramazanoğlu, 2002: 76-77).

rane lokacije, ampak ga lahko dosežejo tudi tisti/tiste raziskovalke/-ci, ki so pozorni do življenja neprivilegiranih, ne glede na to, kakšna je njihova družbena pozicija (Grasswick in Webb, 2002: 193). 


\section{Metodologija z etiko}

P redhodno analizirana spoznavna provenienca ne more biti ločena od metodoloških preferenc, etična razsežnost, ki jo na tem mestu vključujeva, pa je vpisana kot odgovornost raziskovalke in raziskovalca že v samem dejanju pozicioniranja v družbeno strukturo (na mesto, ki ga opredelita kot izhodišče vsakdanjega/znanstvenega/teoretskega vpogleda), in (samo)umestitve v mrežo vednosti, ki jima omogoča dotok iz virov, kompleksov znanj in metod, ki so se oblikovali v raznolikih razumevanjih sveta, zlasti na področjih družboslovja in humanistike.

V pričujočem tekstu izgrajujeva polje znanja/vednosti tako, da uporabljava konceptualni pristop, kot se je uveljavil v okviru različnih znanstvenih ved in disciplin (prim. Beasley, 2005: 3), in je torej heterogen. Obenem iz najine predhodne argumentacije sledi, da je v razlagi in metodološki aplikaciji konceptov (v kategorije) pomembno upoštevati lokalno okolje t. i. postranzicijske družbe in - prav tako glede na že konstatirano, tudi lastno lociranost v njem. Spoznavajoči subjekt je v skladu z opisanimi feminističnimi epistemološkimi temelji na ta ali oni način, ki se izkazuje v samem tekstu ali »tekstu«, tekočem, neprekinjenem diskurzu, ki se dogaja v okviru lastnega izkustvenega sveta, strukturno multiplo opredeljen, »narejen « v intersekciji različnih strukturnih položajev. Hkrati ta subjektiviteta, bolje instanca subjektiviranja nikoli ni fiksna niti na ravni umeščanja v mreži vednosti niti glede položaja v družbeni strukturi, saj tako napredovanje v interpretacijah fenomenov kot analiza lastnega položaja, lociranosti vodi $\mathrm{k}$ novim pozicijam in s tem novim pogledom. Tudi to je značilnost, 
ali bolje, sestavni del in učinek konceptualizacije sodobnega nomadskega subjekta, ali ustrezneje, nomadskega subjektiviranja.

Geografija vednosti, ki jo raziskujoča posameznica ali posameznik osvaja na področju humanistike in družboslovja, je odvisna tudi od želje po ozaveščanju in razumskem obvladovanju določenih mikrosfer, ki ležijo v preseku med $\gg$ zasebnim $\ll$ in $\gg j a v n i m \ll .{ }^{1}$ Ravno želja je porok zavzetosti v raziskovanju. Rečeno z drugimi besedami, šolsko polje in (novi) mediji so tisto, kamor želiva spoznavno intervenirati na podlagi predhodno argumentirane teze, da konstrukcije spolov v medijih/novih medijih in vzgoji in izobraževanju s simbolne, imaginarne in materialne (telesne in tudi objektne, za slednje gl. Luthar, 2007) ravni sooblikujejo in reciklirajo mnogotere matrice družbenega in individualnega bivanja, ki vključujejo spolno hierarhijo in diskriminacijo. Obenem je treba opozoriti, da je umeščanje konstrukcij pornoseksualnosti in nasilja med sfero zasebnega/intime in javnega logična tudi glede na eno od značilnosti novih medijev in njihove uporabe; tu so se, kot dokazuje J. Strehovec, »premešale karte « med omenjenima področjema človeškega življenja (2007: 20).

Glede na to, da statuse in vloge spolov, s poudarkom na ženskah, dekletih in deklicah, ${ }^{2}$ zaznavava, razumeva in analizirava $z$ vidika vladajočega hierarhičnega razmerja, je eden najinih osrednjih delovnih konceptov moč - vidna, prepoznavna in preverljiva oblast, ki pa deluje na mnoge načine in v okviru različnih mikrolokacij (ponotranjenj in/ali utelešenj). Razmerja oblasti v spolni ureditvi ${ }^{3}$ so najprej prepoznavna v vladajočem, neproblematiziranem binarnem opredeljevanju moških in žensk, ki je značilno tudi za danes tako politično in finančno podpirano in promovirano pregledno kvantitativno raziskovanje, vključujoče ogromne mednarodne nabore podatkov.

\footnotetext{
${ }^{1} \mathrm{Z}$ narekovaji opozarjava na specifično ideološko zaznamovanost te delitve. Že drugi feministični val je v šestdesetih letih dvajsetega stoletja opozoril na delovanje oblasti, torej nečesa, kar navidezno pripada sferi javnega, v vseh porah zasebnega. Ta misel je bila najbolj odmevno artikulirana v geslu »osebno je politično «, v teoriji pa je bila nato, kot vemo, elaborirana v delu M. Foucaulta.

${ }^{2}$ Nekatere teoretičarke oporekajo izrazoma dekle/dekleta in ju nadomeščajo z izrazom mlade ženske, da bi na ta način oblikovale predstavo o njihovi vključenosti in kompetencah (oz. da bi jih pozicionirale kot ospoljene subjekte).

${ }^{3}$ Spolna ureditev je v sociologiji in feministični teoriji sintagma, ki je mestoma izpodrinila izraz patriarhat; slednji označuje družbeno strukturo, institucije in diskurze, skozi katere moški nadzirajo ženska telesa in žensko delo ter družbo spolno segmentirajo. Ob tem v velikem delu feministične teorije velja, da je spolna delitev povezana z razredno delitvijo. Pomensko oznaki nista povsem identični: spolna ureditev implicira variabilnost družbenega odnosa med spoloma, in to tudi v okviru dominantnega, patriarhalnega spolnega režima (Pilcher in Whelehan, 2004: 93).
} 
Še preden pa predstaviva interdisciplinarne kvalitativne metodološke pristope, primerne za obravnavano področje, naj nanizava delovne hipoteze, ki so prav tako sestavni del platforme za kompleksno znanstveno preučevanje problematike konstrukcij spolov, spolnosti in nasilja v novih medijih in sposobnosti za odzivnost na šolskem polju. V pričujoči študiji te hipoteze deloma tudi dokazujeva.

\section{Metodološko orientirane in vsebinske hipoteze}

Izhodiščno postavljava dve medsebojno povezani in metodološko orientirani hipotezi. Prva pravi, kot delno nakazujeva že zgoraj, da je pri oblikovanju analitičnih kategorij in zastavljanju vprašanj treba upoštevati tudi povezavo med metodami in epistemološko orientacijo raziskovalca ali raziskovalke, kar je blizu t. i. umeščeni vednosti feministične epistemologije. Druga pa jo dopolnjuje s tem, da predpostavlja, da gre tu iskati tudi razloge za domnevno metodološko enostranskost oziroma nekompleksnost nekaterih raziskav tega področja; slednje sva prav tako omenili že predhodno, ko sva se opredeljevali do kategoričnega spolnega binarizma v raziskovanju.

Glede vsebinskih hipotez je najina tematizacija zelo obsežna, saj vključujeva, denimo, tako sodobne konceptualizacije novih medijev kot aplikativno problematiko regulacije. Trditve zastavljava v preverjanje takole:

- Novi mediji imajo danes bistveno vlogo pri seksualizaciji in ospoljenju otrok in mladostnikov ter njihovem odnosu do nasilja, predvsem nasilne spolnosti.

- Izdelki in storitve ter možnosti rabe informacijsko-komunikacijskih tehnologij (objektna dimenzija novih medijev) aktivno sodelujejo pri vzdrževanju sistemskega nasilja in dominantnih norm ter normalizirajočih modelov spolnih vlog.

- »Tehnološka revolucija« današnjega časa ne omogoča sama po sebi radikalne rekonstrukcije in restrukturacije posameznika/-ce, edukacije in družbe v celoti.

- S spreminjanjem medijskega prostora in javne sfere se dogajajo tudi druge družbene in kulturne spremembe, ki imajo vlogo v recikliranju diskriminatornih razmerij med spoloma, družbenimi razredi/sloji, etnijami ipd.

- Zdravorazumske predpostavke in $\mathrm{v}$ javnem mnenju uveljavljeni predsodki pogosto onemogočajo kritično vrednotenje pojmov in načinov pedagoškega dela ter realistično dojemanje fenomenov novomedijskih kultur. 
- Konstrukcije teles in njihovih interakcij v medijih/novih medijih (medsebojna povezanost nasilja in seksualnosti) imajo lahko negativne učinke na samo materialno telesnost.

- Vladajoče kulturne konstrukcije seksualnosti in nasilja v Sloveniji s komodifikacijo predvsem dekliških in ženskih teles inducirajo slabo samopodobo, ki je povezana tudi z negativnimi pojavi na področju zdravja, predvsem spolnega in reproduktivnega zdravja. Hkrati komercialna seksualna komodifikacija otroških in mladoletnih teles $\mathrm{v}$ slovenskem prostoru povečuje možnosti za zlorabo otrok in mladoletnih za potrebe seksualne industrije in trgovine z ljudmi.

- Regulacija medijskih in novomedijskih konstrukcij medsebojne povezanosti seksualnosti in nasilja prispeva $\mathrm{k}$ oblikovanju družbenih norm, ki v soočanju s proliferacijo pornografske seksualnosti in prikazov seksualiziranega nasilja $\mathrm{v}$ javnem prostoru pomeni pomembno vrednotno orientacijo otrok in mladih.

\section{Metode}

Obravnavano tematiko, tj. konstrukcije in reprezentacije spola, spolnosti in nasilja $v$ povezavi $z$ novimi mediji je mogoče ustrezno zajeti $z$ uporabo pretežno kvalitativnih metod. Meniva, da je kvantifikacija manj ustrezna (ne pa seveda neustrezna!) iz več razlogov. Naštejva jih nekaj (po naključni razporeditvi): s kvantitativnim pristopom $\mathrm{k}$ analizi vsebine (content analysis) so določene težave, zlasti v smislu problema konstrukcije pomena, saj pogostost pojavljanja za konstrukcijo pomena ni osrednja ali odločilna; zahtevajo neko določeno velikost vzorcev; omogočajo širino na račun globine in nam povedo veliko o tem, kje ležijo poudarki, le malo pa o sami interpretaciji. Obenem kvantitativne raziskave, usmerjene $\mathrm{k}$ preučevanju učinka potencialno škodljivih vsebin, zaznamujejo nekatere priznane šibke točke: neenotno opredeljevanje gradiva in neproblematizirane, pavšalno določene kategorije, iz katerih izhajajo ambivalence v raziskovalnih rezultatih. Tretja vrsta raziskav, velike pregledne raziskave z mednarodnimi zajemi podatkov obravnavajo zaradi primerljivosti rezultatov problematiko (gre predvsem za preučevanje spletnih tveganj) poenostavljeno in brez refleksije temeljih kategorij, ki tako ostajajo bolj administrativne kot znanstvene narave.

Kvantitativno raziskovanje ima prav gotovo svojo vlogo in pomen in ustrezno dopolnjuje kvalitativno delo na področju raziskovanja edukacije in spolnih razlik. A s postvaritvijo kategorij, zlasti spolnih, proizvede 
razlage, ki reciklirajo »značilnosti« spolov, in ne dopusti kompleksnejših analiz ženskosti in moškosti (Walkerdine, 1989). Zato jih je treba ustrezno dopolniti s koncepti oz. metodami, ki omogočajo subtilnejše analize.

Meniva, da je interdisciplinarna zastavitev adekvatna, kar pomeni prečenje več teoretskih in znanstvenoraziskovalnih polj in črpanje iz tistih tokov in pristopov, ki omogočajo osvetlitev in zamejitev obravnavane problematike ter razvijanje primerne metodologije, ki vključuje naslednje kvalitativne metode:

- hermenevtična analiza skritih pomenov in sporočil

- lingvistična analiza besed / terminologije $s \gg$ kontroverznimi « pomeni

- semantična analiza randomiziranega nabora komercialnih komunikacijskih in drugih sporočil v medijih

- kritična analiza diskurza, ki prispeva k ugotovitvi, katera sporočila, vrednote, ideje, informacije so vzete kot samoumevne, in ki omogoča razmislek o dominantnih govorih o seksualnosti in nasilju ter kritično analizo njihovih ideoloških ozadij

- kritična analiza, povezana $s$ teorijo ideologije, s katero je mogoče identificirati vladajoče podobe, ki perpetuirajo neenaka socialna, medosebna ipd. razmerja

- primerjalna analiza diskurzov oz. metoda soočenja uradne, $\gg z d r a-$ vorazumske«, verzije družbene realnosti, socialnih in političnih razmerij, zgodovine in konceptualnih kategorij z alternativnimi pogledi na družbo, politično kulturo itn.

- analiza delovanja institucij, ki imajo vlogo regulatorja

- primerjalna analiza temeljnih konceptov ospoljenja in seksualizacije

- segmentacija skupin otrok in mladoletnih glede na starost in pogovori z njimi v fokusnih skupinah, nadaljna segmentacija otrok glede na spol, etnično pripadnost demografsko-kulturno okolje, razred/ sloj, telesne sposobnosti in državljanski status oz. manko le-tega

- analiza izbranih primerov dobre in slabe prakse

- opazovanje z udeležbo v situacijah s pedagoškim kadrom

- biografska metoda: analiza avtobiografskih zgodb.

Izbrane metode predstavljajo multidisciplinarni nabor, povezan s teoretskimi in metodološkimi tokovi feministične teorije in študije spolov, sociologije, antropologije in filozofije (etika). Hkrati omogočajo refleksijo lastne epistemologije in dejavnikov, ki vplivajo na pridobivanje vednosti. V nasle- 
dnjem sklopu predstavljava konceptualni pristop, ki je vendarle ključen za najino delo, povezan pa je ne le s koncepti, temveč tudi z besednjakom, ki ga uporabljava. Kot sledi, metode študija konceptualizacij (in dekonceptualiziranja) ni možno vezati na eno vedo ali področje.

\section{Konceptualni pristop}

$\mathrm{Na}$ tem mestu nekoliko podrobneje pojasnjujeva konceptualni pristop, kot se aplicira v antropologiji; izhodišče je študija Konceptualni pristopi $\mathrm{k}$ študiju spola na področju izobraževanja (Conceptual Approaches to Studying Gender in Education) avtoric J. P. Goetz in L. Grant. Kljub multidisciplinarnosti metode konceptualnega pristopa je vendarle opaziti razlike glede na to, ali se uporablja na primer v okviru empirične sociologije ali pa $\mathrm{v}$ feminističnih študijah, vključno $\mathrm{z}$ antropološkimi. $\mathrm{V}$ nadaljevanju te metodološke refleksije pa uvajava še konceptualni pogled na nove medije z vidika tehnologije oziroma vloge objektov informacijsko-komunikacijske tehnologije.

J. P. Goetz in L. Grant v obravnavi družboslovnega konceptualnega pristopa, aplikabilnega $\mathrm{v}$ antropologiji spolov in izobraževanja, poudarjata analizo strukturnih pogojev in preučevanje simbolnih družbenih procesov, ki se je oblikovala v okvirih strukturalizma. »Strukturalni funkcionalizem « kot družboslovna teorija za razumevanje strukturnih relacij $\mathrm{v}$ družbi ${ }^{4}$ je (poleg »kulturne ekologije «) rojstno mesto dveh tudi v humanistiki težko pogrešljivih konceptov obravnave spolov: spolna vloga in status (spola).

Simbolna raven družbenega življenja (»simbolni procesi«) pa se v obravnavanem okviru pojasnjuje $\mathrm{z} \gg$ družbenim interakcionalizmom « in »družbeno in kulturno reprodukcijo«. Obravnavata ju med seboj prepleteni raziskovanji družbene in kulturne reprodukcije (tu gre za preučevanje utrjevanja in transmisije ideologij, ki podpirajo vztrajno neenako spolno razmerje v šoli, in primerjavo spolnih stratifikacij v šoli in širši družbi) in družbene interakcije (izmenjave med akterji/-kami, ki vodijo do različnih izkušenj v izobraževalnem okolju in v raznolikost socializacij v vloge odraslih žensk in moških). Teme študij interakcije so:

- izkušnje $\mathrm{v}$ formalnem in neformalnem izobraževanju, ki odkrito in prikrito prispevajo k vzdrževanju obstoječih spolnih razmerij

${ }^{4}$ Raziskovanje, kako spolne vloge korespondirajo z družbenimi institucijami in strukturami, kako družbene skupine pojmujejo/uporabljajo spol, da organizirajo vloge, statuse, norme in vrednote (prim. Goetz in Grant, 1988: 183-184). 
- prežetje izobraževalnih okolij s spolnim simbolizmom

- utelešanje spolne stratifikacije skozi vsakdanje šolske izkušnje

- oblikovanje in izkazovanje spolnih identitet in repertoarjev spolno »stereotipnih« vlog $s$ strani učiteljev/-ic in prtofesoric/-jev ter učenk/-cev in dijakinj/-kov

- perspektive življenjskega poteka glede na spol in vzgojo in izobraževanje

- strukturne značilnosti učilnic in šol (na primer oblikovanje skupin glede na sposobnost) in njihov posredni vpliv na spolna razmerja

- razlike v ženskosti in moškosti glede na raso, etnično skupino, razred

- intersekcije med pomnoženimi statusi, ki modicirajo spolne izkušnje v izobraževanju (in vzgoji), in vloge, ki jih imajo šolajoči se glede na spreminjajočo se statusno konfiguracijo

- načine deške priučitve in izvajanja dominacije in poniževanja žensk

- motivacije dečkov/fantov za podreditev žensk, ki vzniknejo v šolskem okolju

V ospredju vseh navedenih tematizacij so odnosi moči, ki pa jih študije družbeno-kulturne reprodukcije obravnavajo kot osrednjo relacijo skozi preučevanje:

- kulturne produkcije oblik zavesti, vedenja in pričakovanj v družbenih podskupinah

- utrjevanja obstoječih spolnih razmerij

- paradigem spolnih razlik, ki se kažejo kot prostovoljno izbrane in utemeljene bolj v nekakšnih značilnostih kot v sistematičnem seksizmu.

Študije kulturne in družbene reprodukcije interpretirajo transmisije in transformacije spolnih (gender) relacij, pri čemer pa ne gre za zgolj enoznačno ugotavljanje strukturnih razmerij, temveč za detektiranje negotovosti in nasprotij, $s$ tem da se lahko določena spolna vloga ne le interpretira, temveč tudi udejanja v različnih fazah življenja na različnih pozicijah moči (Goetz in Grant, 1988: 187-190). S pozicije moči pa je ženska/dekliška vloga lahko tudi ambivalentna. Sami na primer v tekstu opisujeva primer »deških« deklic (ladettes), ki so uporniške po svojem zunanjem videzu in vedenju, ne pa po čustvovanju. Obenem uporniška vloga ne varuje pred zdrsom v spolno podrejeno vlogo v odraslosti, še več, uporništvo, prekinjeno šolanje, zgodnja nosečnost lahko še pospešijo prevzemanje take vloge (Anyon, v Goetz in Grant, 1988: 189). 
Kot je razvidno iz pričujočega »popisa« usmeritev in tematik konceptualnega pristopa $\mathrm{k}$ antropologiji spola in izobraževanja, ni zabeležiti razlik z aparatom, ki ga uporablja feministično raziskovanje ali, denimo, kritična analiza družbe, kot je aplicirana $v$ študije spolov in feministično refleksijo. Kljub temu pa je treba opozoriti na določen poudarek, ki je videti domena teh, slednjih področij. Gre za previdnost in refleksivnost v uporabi pojmovnega aparata in konceptualizacijah ter dekonstruiranjih temeljnih pojmov in kategorij, kot so spol, ženske/žensko, moški/moško, spolna razlika, subjekt, identiteta, diskurzivno/simbolno. Prav analiza tega nazadnje navedenega koncepta, koncepta simbolnega, privede tu na področje, ki je $\mathrm{v}$ fokusu najinega raziskovalnega interesa - materialna raven konstrukcij spolov in sprege spolnosti in nasilja.

Težko bi bilo namreč razviti misel, da se na obravnavanem polju gibljeva pretežno na ravni (razlage) simbolizacij. Odnosi med ljudmi, znaki/pomeni in stvarmi (vključujočimi materialno razsežnost prostora, kot je na primer razred ali šola) so lahko danes v ločitvi mišljeni samo v obliki sheme; pri strukturiranju na objektni in simbolni svet v sodobnem družboslovju/humanistiki gre bolj za pripomoček mišljenja kot razumevanje samo. V tem smislu se velja opredeliti do družboslovne teorije, ki postavlja objekte $\mathrm{v}$ interpretativno središče (objekti kot osrednji akterji) razumevanja sodobnih družb (ta teoretski trend v razlagi novih medijev opisuje B. Luthar, 2007).

Materialne stvari so za družbene vede bodisi v celoti zunanje okolje ali objektivni svet bodisi simbolna artikulacija družbenih razmerij. Tako materialnost včasih ostaja okolje zunaj subjekta, drugič ljudje stopajo v interakcijo z ločenimimi objekti, ali pa se materialne objekte uporablja kot orodja, ki povečajo človeško instrumentalnost, torej kot akterjev podaljšek (ibid.: S7).

Vloga tehnopredmetov v sodobnem družbeno-kulturnem okolju je bila $s$ feministične teoretske perspektive raznoliko tematizirana, pomembno je zlasti razumevanje vitalne spetosti objektov (ne le njihovih pomenov) in človeškega delovanja ter čutenja (prim. Haraway, 1999). Enako zanimanje za objekte je zaznati v socioloških študijah kulture. Pripoznano je na

\footnotetext{
${ }^{5}$ Najbolj slaven primer je nedvomno »Kiborški manifest « D. Haraway (1999, v orig. izšel leta 1985), v katerem D. Haraway vpelje kiborga (kiborginjo) kot mejno bitje, križanca med strojem in organizmom, a hkrati ne kot nekaj (do)končanega, pač pa nekaj, kar se nenehno transformira in misli na novo. Kiborg je figuracija (ne sicer edina v njenem »kritično-teoretičnem ZOO-ju «, kot pravi sama), ki zahteva, da razmislimo o vidikih komunikacijskih sistemov, o spajanju organskega in tehnološkega, saj so komunikacijske tehnologije in biotehnologije »odločilna orodja, ki na novo izdelujejo naša telesa« (Haraway, 1999: 264). A kiborg ne pomeni hkrati kar vsakega
} 
primer Jamesonovo interpretiranje oglaševanja in pornografije, ki hiperpotrošniške predmete in pornomaterial podobno razume v funkciji novega strukturiranja bivanja in čutenja (1991). Prav tako raziskovanje pričujočega področja novih medijev v segmentu pornografije pogosto vzame v precep objektna razmerja. Naj izpostaviva na primer ekransko površino in »trzavice « tehnološko slabe produkcije porna ali pa lesk lista v pornoreviji kot akterje $\mathrm{v}$ procesu fiziološkega odziva tekom pornokonzumpcije, ki je $\mathrm{v}$ jedru sodobnega raziskovanja porna in njegovih spolno diskriminatornih razmerij (MacKinnon, 1996; Melendez, 2004). K tej problematiki se bova še vrnili, morda bi na tem mestu omenili le še tematizacijo kibernetskih svetov, kjer človeški organizem vibrira v skladu $s$ »povečano resničnostjo « v taktilni, avdiovizualni dimenziji (Williams, v Wall, 2007: 129; Strehovec, 2007: 219), čeprav gre za »le《za imaginarni produkt človeka uporabnika, producenta in stroja.

Interakcija med človekom in objektom/aparatom/strojem ima prav zaradi delovanja na čustveno-čutni ravni pomembno vlogo v temeljnih družbenih strukturah. Gre za stvarno izkušanje denimo pogubljenosti ali moči, četudi je človek »zgolj《 v odnosu z ekranom mobilnega telefona (Strehovec, 2007: 188) ali pa se »dotika« drugega z roko na miški ali sprožilcu.

Stvari torej lahko razumemo kot akterje, ne zgolj kot pasivne objekte. Nečloveški akterji, ki delujejo, kot bi bila v njihovo delovanje vključena namera, volja, se mešajo s človeškimi in tako oblikujejo mrežo. Materialni objekti postanejo nosilci družbenih pravil, ki so aplicirana na ljudi in na ta način posegajo v odnose moči ter nadzorujejo védenje in družbene prakse. To delovanje seveda ni primerljivo z refleksivno zavestjo, ki je značilna za ljudi. Objekti imajo vlogo akterja, toda njihovo delovanje izhaja iz človeškega delovanja, ki jih oblikuje, uporablja (Luthar, 2007: S14).

$\mathrm{V}$ pričujoči razpravi na konkretnih primerih nasilja in spolnega nasilja v slovenskih osnovnih in srednjih šolah analizirava pomemben, »aktivni « status in vlogo mobilnega telefona in spleta $\mathrm{v}$ smislu produkcije samega dogodka in njegovih razsežnosti v medosebnih odnosih. $S$ te pozicije bi se lahko reklo, da ima omenjena »sociologija materialnosti« vrednost predvsem zato, ker poudarja objektni aspekt družbe (je »objektnosrediščna«, prim. ibid.: 11), ne pa, ker bi razumela razmerje med ljudmi in objekti pri vzdrževanju družbenih oblik na radikalno nov, »bolj resničen « ali bolj »poglobljen« način. Prej se zdi, da gre za premeno fokusa.

artefaktnega, strojnega razmerja s človeškimi bitji. Za več o tem gl. Haraway, 2000: 127, in nasl.; Haraway, 1999: 241, in nasl. 


\section{Etika}

Etika raziskovanja je predmet razprav in opredelitev zlasti v povezavi z odnosom do informatorjev/-k, respondentov/-k, posebej še pri etnografskih metodah, kjer je odnos poosebljen in identiteta $\mathrm{v}$ procesu pripovedi neprikrito pričujoča, nabor podatkov izčrpnejši in najpogosteje povezan z zasebnostjo. Posledično so okviru etnologije in antropologije poklicni kodeksi in norme raziskovalnega védenja znanstveno priznana tematika, ki pa se ne dotika samo problematike informatorskih oseb. M. Ramšak v uvodnem delu monografije o študijskem primeru življenjskih zgodb Portret glasov navaja tri tematska področja oziroma »osnovna načela« etnografske etike; prvo se nanaša na »nosilce informacij« oziroma na informatorsko ali ciljno skupino (objekt raziskovanja). Drugo zadeva odnos do kolegov/-ic, in kot v nadaljevanju izpostavi avtorica, gre $\mathrm{v}$ tem primeru tudi za problematiko preverljivosti in nadaljevanja znanstvenega dela; tretje načelo pa je povezano z odnosom raziskovalnega subjekta do »sponzorjev«, tj. instanc financiranja (2003: 128).

Informatorska skupina iz etične perspektive odpira vrsto refleksij, tista najpogostejša pa je praviloma povezana z normami človekovih pravic, ki so tudi zakonsko opredeljene. Gre za tajnost podatkov in spoštovanje človeške integritete, pri čemer utegne neetično ravnanje povzročiti moralno škodo (lahko pa tudi povsem oprijemljivo škodo v konkretnih odnosih osebe, ki informira). Razmerje, ki to škodo lahko povzroči, je razmerje izkoriščanja, ki mu avtorica zoperstavlja Kantov moralni imperativ (ibid.: 126). Zdi se, da je prvi napotek, ali bolje, obveznost raziskovalke in raziskovalca $\mathrm{v}$ situaciji pred pridobivanjem osebnih informacij dobiti privoljenje govorca/-ke ali pisnega pričevalca/-ke in mu/ji zagotoviti anonimnost. Pravilo, ki se v navedenem delu postavlja v povezavi z življenjsko zgodbo, velja za vsako etnografsko in, širše, kvalitativno metodo, ki temelji na personificiranem odnosu in pri kateri je identiteta informatorske osebe znana. Zahteva po etični drži raziskovalcev in raziskovalk, njena ustreznost, ki je eno od meril za kakovost znanstvenoraziskovalnega projekta, običajno ni sistematično razdelana in običajno (vsaj na »naših «, feminističnih, socioloških, antropoloških raziskovalnih področjih) zadostuje izjava o etičnem odnosu do informatorskih oseb in navedba v smislu, da so osebni podatki zavarovani in viri v raziskovalni študiji neprepoznavni. Enako velja za etičnost pristopa k obravnavanim kvalitativnim metodam, ki se uporabljajo za pridobivanje podatkov v okviru različnih strokovnih dejavnosti, na primer v trženju ali zdravstvu (Kreuger in Casey, 2000; Family Health International). 
Tej navidezni preprostosti navkljub pa etika raziskovanja že v območju obveznosti o anonimnosti virov v zapisu in poročanju o informacijah, ${ }^{6} \mathrm{ki}$ so povezane z zasebnostjo in intimo, postavlja pred nas osrednjo kontroverzo. M. Ramšak jo nakazuje med vrsticami. Kot pravi, je posledica anonimnosti virov nepreverljivost raziskovalnega dela in nemožnost nadaljevanja raziskave s strani drugega raziskovalca ali raziskovalke. Hkrati je tako »vzet« glas tistim, katerih možnosti, da bi bili v družbi slišani, so že tako ali tako močno okrnjene (ibid.: 141).

Protiargument, da se oseba, ki informira, sama odloči, ali želi biti navedena kot vir ali ne, ne ustreza povsem, saj ne upošteva razmerij moči, skozi katere se kažeta marginalna govorka in govorec kot manj kredibilna, če je njun glas osamljen. Na ta način lahko razumemo odločitev za anonimnost kot prisilno, čeprav gre za ponotranjenje razmerij moči in ne za dejansko opresijo. Hkrati pa je treba opozoriti še na dodaten problem, ki se nanaša zgolj na en segment prikrivanja identitete; raziskovanje po principu zaukazane neprepoznavnosti v procesu snemanja in zapisovanja opažanj včasih enostavno ne deluje.

Kot opozarja M. Eisenhart, je vztrajna napetost med nujo zaščititi osebe, ki informirajo, in potrebo navajati podrobnosti, ki omogočajo globlje razumevanje, tu pogosto osrednja. Ta napetost se še zaostri, ko je treba predstaviti multiple in različne perspektive (ali »glasove«). Denimo: kaj pa, če $s$ tem, ko zaščitimo nekatere sodelujoče, razkrijemo ali privilegiramo druge? Kaj pa če je razumevanje ene perspektive odvisno od razkritja razmerja do druge, ki bi jo bilo treba zaščititi? (Eisenhart, 2001: 19.)

Avtorici sva etična načela raziskovanja na opisani ravni aplicirali zlasti v pripravi diskusij v dveh fokusnih skupinah otrok, ${ }^{7}$ ki sta bili izvedeni v okviru projekta $\gg$ Epistemološki in kulturni vidiki konstrukcije spolnosti in nasilja v novih informacijsko-komunikacijskih tehnologijah (IKT) ter njihovo sprejemanje pri otrocih in mladih $\ll .{ }^{8} \mathrm{O}$ diskusijah so otroke informirali starši, ti so kot njihovi zastopniki/-ce tudi podpisali soglasje za udeležbo. Predhodne (pisne) informacije, ki so jih dobili starši, so vključevale osnovne podatke o raziskavi in opredelitev odgovornih oseb glede rabe pridobljenih informacij ter zagotovilo o anonimnosti osebnih podatkov v procesu znanstvenoraziskovalne obdelave. Predstavljen je bil raziskovalni namen, naštete so bile posamezne tematike in način izvajanja pogovo-

\footnotetext{
${ }^{6}$ Izjema so primeri, ko se informator/-ka želi razkriti.

${ }^{7}$ Interpretativno delo se v času pisanja monografske publikacije še ni začelo.

${ }^{8}$ Izvajata ga avtorici pričujočega dela, prvopodpisana kot vodja (s strani Pedagoškega inštituta), financira pa ga ARRS.
} 
ra, z obljubo, da je v sklepnem delu načrtovano izobraževalno informiranje otrok o temi (konstrukcije/podobe spolnosti in nasilja). Otroci dveh starostnih skupin (6. in 8. razred osnovne šole) so bili prav tako kot njihovi starši, a na zanje ustrezni ravni, seznanjeni z vsem naštetim na začetku izvedbe pogovora $v$ fokusnih skupinah. ${ }^{9}$ Večji problem, ki se je pokazal med pripravo, je bilo prav vprašanje zakrivanja identitete otrok v samem pogovoru. Glede na okoliščine, med katerimi naj izpostaviva občutljivost teme, domačnost med otroki (sošolke in sošolci) in izjemnost situacije, ki je vključevala prisotnost tujih oseb, sva presodili, da bi etnografsko pravilo izmišljenih imen ali kod sodelujočih (ki velja za snemanja in beleženja) dalo izvedbi pridih komičnosti in absurdnosti. Zato so bili otroci med pogovorom poimenovani s svojimi lastnimi imeni, hkrati pa so lističi z zapisom kode ob imenu, ki so jih imeli pred sabo, omogočili, da so terenski zapiski kodirani in identiteta otrok $s$ tem zakrita. Enako velja tudi za transkript.

Kljub relevantnosti omenjene problematike, ki sva jo pojasnili v okviru etnografskih metod, se iz najinega zornega kota temeljna in najbolj daljnosežna etična dilema feminističnega, antropološkega in sociološkega raziskovanja skriva drugje. Nanjo sva že opozorili v obravnavi epistemoloških izhodišč raziskovanja. Naj jo tule predstaviva v obliki vprašanja in nato nanj odgovoriva nekoliko drugače. Je etični odnos oziroma konstitucija moralne raziskovalne subjektivitete možna brez prepoznavanja in občutljivosti za učinke znanstvenega diskurza na strukturna razmerja v družbi in $s$ tem tudi na posameznico in posameznika v njuni substancialni biti? ${ }^{10}$

Jezik skozi univerzalizacijo in abstrahiranje, ki temeljita na ideji (ovrednotene) razlike, zajeda substancialnost telesa (Kellogg, 2001: 19). To še posebej velja za govor, ki si lasti značaj znanstvene »resnice«. Navedena transgresivna razsežnost daje vsebini dodaten pomen; posredovane misli so spete $\mathrm{z}$ občutki in telesnimi odzivi oziroma beseda se ugnezdi v telo, tako da najprej dekonstruira sebstvo na telesni ravni in ga nato rekonstruira. Občutljivost, ki presega razumevanje za položaj druge/-ga, se odraža v enem od ciljev feministične etike, kot jih definira feministična filozofinja A. M. Jaggar. Gre za »moralno kritiko« delovanja in praks, ki vzdržujejo podrejeni položaj žensk, pri čemer delo v okvirih feminizmov ni izvzeto (1991: 528-529). Na tej ravni lahko prepoznavamo izhodišče za feminiz-

\footnotetext{
${ }^{9}$ Pogovor je moderirala podiplomska študentka Nina Sirk (Univerza v Novi Gorici, Interkulturni študiji - primerjalni študij idej in kultur, smer: medicinska antropologija).

${ }^{10}$ Denimo, kot piše M. Eisenhart, se je treba spopasti tudi z vprašanji, kako predstaviti »vročo « informacijo o skupini, kot so revne in neporočene matere, ko pa bo politična desnica to informacijo uporabila proti skupini (Eisenhart, 2001: 20).
} 
me, ki so diferencirali položaj žensk, najprej iz perspektive »rase«, etnije in imperializma, in se deloma tudi odpovedali ideji zastopništva.

A. M. Jaggar v svoji enciklopedični razpravi o feministični etiki pripisuje moralni refleksiji uvajanje določenih tem $\mathrm{v}$ raziskovanje, ki je bilo izvorno feminističnega značaja. Povezane so s telesom: abortus, seksualnost, kompulzivna (normativna) heteroseksualnost, spolno nadlegovanje in posilstvo, reprezentacije/konstrukcije »moškosti« in »ženskosti«, zlasti v povezavi z množičnimi/informativnimi mediji in pornografijo, delitev domačega dela, samoprezentacija, vključno s telesno samopodobo in modnim videzom, in kot zelo pomembno, tudi vloga jezika v utrjevanju in izražanju podrejenega položaja žensk. V tematizaciji telesa se proizvede tudi feministična kritika razsvetljenskega pojmovanja individua (Jaggar, 1991: 534-535).

V nasprotju z neoliberalnimi stališči, ki so do moči zakonov zadržana, hkrati pa ne preizprašujejo neformalnih norm vsakdanjosti, ki konstituirajo življenje, so feminizmi iz tez o normiranju spola, spolnosti in teles razvili teorijo družbenega subjekta, ki ga »držijo skupaj《 norme pridobivanja vednosti in življenjske prakse. Za feministično perspektivo je potemtakem značilen ambivalenten odnos do norm: dekonstrukcija tradicionalnih diskriminatornih norm spolov, spolnosti, telesnosti, hkrati pa ustvarjanje novih norm v okviru marginaliziranih skupin. J. Butler ob tem izpostavlja (tudi empirično) vprašanje intelegibilnosti norm iz večinskega zornega kota in ugotavlja, da je boljša neintelegibilnost kot podrejanje. Obenem opisuje manjšinske norme kot prehodne, $\mathrm{z}$ vlogo $\mathrm{v}$ transformaciji sebstva in nasprotovanju univerzabilnosti. Diferencirana pozicioniranja, ki sovpadajo z diferencirano željo, so učinek delujočega subjekta (Butler, 2004: 3). Ta delujoči subjekt, ki je marginaliziran, procesiran in brez stabilne identitete, je manj intelegibilen, tudi ko je ali postane subjekt raziskovanja. Ta odprtost subjekta znanosti in teorije pomeni fleksibilnost v prepoznavanju lastne umeščenosti v mreži vednosti, ki se spreminja z novimi refleksijami in spoznanji. »Etični refleks« proti univerzalizmu norm, kot delovanje za omejevanje univerzalizma opredeli J. Butler (ibid.: 8), je torej osnovna etična drža v feminističnem raziskovanju razsežnosti spola, pa naj gre za izhodiščni odnos do tradicionalnih oziroma konvencionalnih norm ospoljenj ali samo za (samo)umestitev raziskovalke.

Tako etično »normiranje« raziskovanja razumeva kot ključno za sodoben pristop v družboslovnih in humanističnih vedah. Če se tule vrneva $\mathrm{k}$ svojemu izhodišču v obravnavi vprašanja etike, torej k vidiku etike v etnografskih metodah, morava dodati nov poudarek. Preskriptivna dimenzi- 
ja zgodbe informatorske osebe je vpisana v deskripcijo, saj jo naredi intelegibilno na določeni ravni pojmovanja, ki ga s tem utrjuje (če parafrazirava M. Ramšak, 2003: 151). Hkrati pa je taka predpisovalna razsežnost vsebine značilna tudi za »zgodbo« raziskovalke in raziskovalca. V predhodnih epistemoloških in metodoloških izhodiščih in tezah sva obravnavali problematiko pristopa $\mathrm{k}$ vednosti in same konceptualizacije raziskovalnih kategorij, ki se prav tako dotikata etike, tule pa se soočava tudi s povsem konkretnim problemom, kako zapisati paradigmatsko, a »živo « zgodbo in se pri tem držati izbranih etičnih načel. Na izziv sva naleteli pri svojem projektnem delu, ${ }^{11}$ lotili pa sva se ga tako, da sva povezali problematiko identitete in človeške integritete vira $\mathrm{v}$ znanstvenem raziskovanju in razumevanje učinkov diskurzov na utelešene »usode «. Teza o substancialnem delovanju govora je bila v okviru nekaterih konkretnih študij primerov kot realna možnost povsem nazorna in prozaična. Poročila o nasilju in spolnem nasilju nad otroki in med njimi ter otrok nad učiteljicami/-ji bi skozi prepoznavnost vira in zgodbe lahko dobila povsem neželeno razsežnost.

Če bi opisali pogoje možnosti za reprodukcijo nasilja in spolnega nasilja (ne glede na to, ali se to reproducira z utrjevanjem nasilniškega ali žrtvenega položaja) s pomočjo konkretnih, dejanskih primerov, bi mnogokrat nehote implicitno predpostavljali tudi življenjski potek vpletenih oseb. Kljub temu, da določene življenjske okoliščine ustvarjajo pogoje za določeno »usodo«, pa gre za možnost (lahko tudi verjetnost), ne pa nujo. Preko pojmovanja neposrednosti, vzročnosti vezi med družbenimi in kulturnimi pogoji in razvojem individualnega življenja se oblikuje matrica za reprodukcijo družbenostrukturnih razmerij. Temu se je treba izogniti, hkrati pa je pogoje življenja, v našem primeru otrok in odraščajočih, dobro ilustrativno, konkretneje opisati. Da bi najin diskurz odseval obe zahtevi, tj. zahtevo po nazornosti na eni in spoštovanje integritete in individualnosti ${ }^{12}$ nosilcev/-k zgodb na drugi strani, sva se odločili za dva pristopa. O konkretnih primerih, ki so se ponavljali, poročava v obliki opisa fenomena. Posebne dogodke, ki pa so vendarle povezani s trendi v socializaciji otrok (če slovenski prostor primerjava s tujino), pa zapisujeva shematizirano in v nizu izstopajočih primerov.

\footnotetext{
${ }^{11} \mathrm{Na}$ tem mestu se nanašava na projekt »Profesionalno usposabljanje strokovnih delavcev v vzgoji in izobraževanju v letih 2008/2011 na področju socialnih in državljanskih kompetenc« in na tematski sklop $6 \mathrm{v}$ tem okviru: Prepoznavanje in preprečevanje nasilja. Projekt vodi Pedagoška fakulteta Univerze v Ljubljani, financira pa ga Ministrstvo za šolstvo in šport RS.

${ }_{12} \mathrm{Z}$ »individualnostjo« se ne nanašava na neoliberalni koncept domnevno svobodne posameznice in posameznika; $\mathrm{s}$ tem terminom opredeljujeva specifičen in kompleksen, neulovljivo individualiziran splet družbenih in kulturnih okoliščin, ki konstituirajo individuum.
} 
Etična dimenzija razmisleka o lastnem raziskovalnem delu prikliče $\mathrm{v}$ obravnavo še dve temi, ene sva se že predhodno dotaknili. Gre za moč položaja raziskovalke (»tiste, ki ve«), ki jo je treba omejiti s priznavanjem omejitev. Te se ne nanašajo zgolj na umeščenost $\mathrm{v}$ sferi (znanstvene) vednosti, ki sva jo že opredelili z navedbo svojih področnih preferenc (in jo tudi sproti nakazujeva z navajanjem virov in izpeljavo koncepcij). Spoznavni razpon, ki ni razvezljiv od emocionalnih investicij v objekte in raziskovalne teme, se prvenstveno določa $\mathrm{v}$ odnosu do lastne pozicioniranosti $\mathrm{v}$ družbeno-kulturnih razmerjih, tj. v odnosu do sposobnosti reflektiranja lastne lokacije. Najina perspektiva je v tem smislu srednjeslojna in urbana, ne povsem neodvisna od evropocentrizma in »postranzicijskega « okolja, heteroseksualna in zaznamovana z levo alternativno, tj. družbenimi gibanji osemdesetih let preteklega stoletja. $S$ to opredelitvijo se ne distancirava od, denimo, tematizacije homoseksualnosti in lezbištva ali problematike revščine, odrekava pa se zastopniškim intencam v zvezi z navedenimi družbenimi skupinami. Hkrati je treba priznati, da izkušnje, pridobljene v okviru najinih življenjskih in refleksivnih lokacij/pozicij, pojasnjujejo nekatere poudarke $\mathrm{v}$ raziskovanju in senzibilnosti za določene teme in celo objekte raziskovanja. Vzemimo kot najbolj eklatanten primer znanstvenoraziskovalni interes za segment otrok, posebej njihovo ospoljenje. ${ }^{13}$ Povezan je z zavestjo o položaju žensk (v specifični družbeno-kulturni konstelaciji) in navezujočim se delovanjem; medsebojna povezanost med delovanjem za ženske in za otroke pa je, kot dokazuje M. Dobnikar, za feminizme kar značilna (2009). Sami interesa za segment otrok, kot je bilo izpričano tudi že drugje, ne povezujeva s tradicionalno žensko vlogo, ki se udejanja v skrbi za druge (če pri tem mislimo na skupinski družbeni subjekt). Veževa ga na položaj žensk, ki je prepleten s socializacijo in odraščanjem v registru spola.

Razsežnost etike se je odprla tudi pri razmisleku o oblikovanju kurikuluma za »spolno vzgojo «. J. A. Diorio naredi primerjavo z medicinsko prakso, kjer se pričakuje, da bodo zdravniki in zdravnice spremljali svoje področje in bili seznanjeni z najnovejšimi izsledki na področju denimo zdravljenja specifičnih bolezni. Zdravniki in zdravnice delajo v kulturi, kjer se pričakuje, da vedo, da to morajo početi. Kaj pa učitelji in učiteljice »spolne vzgoje « ter sestavljalci in sestavljalke kurikulumov? Ti so umeščeni v sfero, kjer takih pričakovanj očitno ni: »Prav gotovo velja obveznost spremljati področje tudi za edukatorje in edukatorke. Dejstvo, da te obveznosti ne prepoznajo ne sami ne splošna javnost, ne zmanjšuje tega, da je ne spre-

${ }^{13} \mathrm{O}$ nastanku koncepta ospoljenja v slovenskem jeziku gl. Šribar, 2004: 14. 
mljati področja narobe.« (Diorio, 2001: 297, in nasl.) Ta ugotovitev je pertinentna ne glede na to, ali so nove teorije o seksualnosti točne ali ne. Posledice takega ravnanja so potencialno škodljive, zato je napačno, da ta kultura ne razvije pričakovanj, da bodo praktiki ostajali na tekočem s teoretičnim razvojem, ki je relevanten za njihovo delo. Minimalna zahteva etike poučevanja tega področja bi tako bila, da edukatorji pokažejo, da seksualnosti ne jemljejo kot samoumevne, da so preučili obseg možnosti na tem področju - čeprav je težko definirati, kakšne so meje - in zakaj uporabljajo prav ta pristop ali perspektivo. Če merimo po tem minimalnem standardu, piše J. A. Diorio, se izkaže, da ga velik del poučevanja ne dosega (Diorio, 2001: 298).

Parametre »spolne vzgoje«, ki jih tu predstavljava v okviru platforme strategij za izboljšanje stanja na obravnavanem področju, zato dopolnjujeva s komentarjem v obliki smernic za ustrezne izbire med možnimi (denimo kompetentni edukatorji/-ke in ne nekompetentni, pri čemer potem katoliško duhovništvo ne le implicitno, marveč tudi eksplicitno ni več opcija). 


\section{Polje vzgoje in \\ izobraževanja: \\ identifikacija \\ problematike in \\ usmeritve na poti $\mathrm{k}$ dobrim praksam}

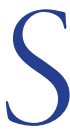

lovenija tako na področju vzpostavljanja znanstvenega aparata za obravnavanje spolov kot tudi na področju t. i. spolne vzgoje v osnovnih in srednjih šolah beleži manko. »Spolna vzgoja « je v najbolj razvitih demokratičnih družbah pomemben formalni okvir za obravnavo spolnih vlog, osebnostne integritete, spolnih usmeritev, samopodobe, pa tudi nasilja, komercialnih konstrukcij seksualnosti, tveganj spletnih pornografskih strani in podobno. Strateški dokumenti EU in OZN poudarjajo pomen zdrave spolnosti in reprodukcijskega zdravja mladih in še posebej deklic. Opozarjajo, da je informiranost na področju spolnosti pomembna tako z vidika spolnega zdravja (preprečevanje spolno prenosljivih okužb, (pre)zgodnje nosečnosti in spolnih zlorab) kot $\mathrm{z}$ vidika osebnostne integritete in razvoja ter vključevanja v družbo skozi nadaljevanje izobraževanja in poklicno izbiro.

Študije, ki so bile narejene predvsem v tujini (ZDA, Veliki Britaniji, Skandinaviji), kažejo na povezanost med tradicionalnimi spolnimi vlogami v seksualnosti in nasiljem ter spolnim nasiljem; poudarek refleksije je na normiranju spolnosti in normaliziranju spolno (gender) zaznamovanega nasilja v seksualnosti in ne na neposrednem učinku obravnavanih konstrukcij (Šribar, 2006). Ta problem je še posebej pereč v sodobni družbi, saj je prežeta z medijskim diskurzom in tehnološko posredovano komunikacijo, ki skupaj obnavljata in poživljata diskriminatorne tradicionalne spolne vloge v spolnosti in širše v medosebnih odnosih (samoumevnost izvajanja nasilja kot znaka moškosti). Obenem so tudi same komercialne konstrukcije na ravni produkcije pogosto prizorišče spolnih zlorab ali celo orodje pri 
spolnih zločinih. Če šola ne da ustreznih informacij, ki delujejo kot protiutež komercialnim konstrukcijam seksualnosti in nasilja, so otroci na tem področju prepuščeni samim sebi oziroma je njihova dobrobit odvisna zgolj od zrelosti, informiranosti in razpoložljivosti drugih pomembnih odraslih (ki pa svojo nalogo opravijo ali pa tudi ne). Posredovanje znanja in učenje na tem področju je v Sloveniji še toliko bolj pomembno, saj v nevladnem sektorju ni organizacije, ki bi se celovito posvečala obravnavani problematiki, tako da bi bila sistematično in prepoznavno vpeta v javni diskurz.

Vzgoja in izobraževanje sta polji, ki otrokom in mladim skozi predmetnike in prikriti kurikulum posredujeta mnoge vsebine in usmeritve, ki zadevajo seksualnost in nasilje; obe sferi sta spontano pojmovani kot naravni, problemi se navidezno zastavljajo zgolj glede uravnavanja teh fenomenov življenja. Spregledana pa je tudi že omenjena pomembna vloga pojmovanja spola prav v razmerjih spolnosti in nasilja. $V$ tem smislu zarisujeva nekatere točke, kjer je feministična refleksija najrelevantnejša (ali bi vsaj morala biti), še sploh, ker je spol kot osrednje (ali eno od osrednjih) organizacijskih načel v izobraževanju vse prepogosto spregledan (Leach, 1990: 455) oziroma razumljen kot nekaj, kar je nepomembno ali kar je morda bilo pomembno, pa ni več, kar je najbrž del iste retorike spregledovanja. ${ }^{1}$ Prav ta »nevprašljivost « je lahko zelo indikativna, ker povzroči, da se problematika zakrije, da se zazdi, da problemov ni, in so tako negativni učinki lahko še močnejši. Posebej z vidika družbene enakosti spolov in pravic žensk in deklic so te pedagoške vsebine, ki ne opuščajo diskriminatornega diskurza o tradicionalnih spolnih vlogah, mnogokrat družbeno in osebnostno destruktivne, hkrati pa neizprašane. Tako se, kot že navedeno, pogosto povezujejo $\mathrm{z}$ agresivnim vedenjem dečkov. Obenem še vedno velja pričakovanje o trpnosti (pasivnosti) deklic. Lahko bi tudi rekli, da se obstoječe spolne hierarhije podpirajo prav s tem, da se o vprašanjih in problemih ne govori (Russell, 1986: 350).

Kaj »enakost med spoloma« sicer natanko implicira, je lahko sporno, tako v feminizmu kot zunaj njega. To pa ne pomeni, da je vse delo, ki je zastavljeno drugače in ki o razlikah med spoloma ne razmišlja, napačno in da obstaja preprosta, neproblematična resnica (Walkerdine, 1989: 1-2, 6;

\footnotetext{
${ }^{1}$ Tudi na ravni predšolske vzgoje se $s$ temi problemi ne spopadamo vedno ustrezno. V okviru stalnega strokovnega izpopolnjevanja za vzgojiteljice (l. 2000 in nasl.) je vprašanje spolne razlike običajno zbudilo začudenje in odgovore v eni od naslednjih smeri: pri nas tega ni; imamo druge probleme; fantje so fantje, punce pa punce ipd. Podobno piše E. D. Bahovec (v Bahovec in Bregar Golobič, 2004: 13), da je pri sprejemanju Kurikuluma za vrtce (izšel je l. 1999) sorazmerno veliko oporekanja spodbudilo prav področje pravic deklic in da je bil glavni argument, da v našem edukacijskem sistemu diskriminacije po spolu ni.
} 
Vendramin, 2006: 89, 93-94). Gre za to, da so resnice konstruirane v določenih svetovih in omejene na določena stališča. Pomembno je preizprašati okvire razprave - kar ne pomeni, da gre za relativiziranje resnice, marveč za širitev pogleda na to, kako neko resnico raziskujemo (Cealey Harrison, v Francis in Skelton, 2001: 56-57).

$\mathrm{Z}$ roko v roki pa gresta tu poleg kategorialnega nasprotja »aktivnost « proti »pasivnosti《 tudi sintagmatski nasprotji med »pravim razumevanjem《 proti »učenju na pamet «, ki ju pogosto proizvajata psihološka vednost in pedagoška praksa. Te interpretacije izoblikujejo različne resnice o tem, kakšne so deklice/ženske, kaj je primerno zanje (tovrstne povezave prevevajo učne ure, obšolske dejavnosti, jezik, vednost): kako je denimo $\gg$ neuspeh deklic stvar pomanjkljivega smisla za matematiko in logično sklepanje, medtem ko so dečki domnevni nosilci pravega in resničnega razumevanja in matematičnega znanja« (Bahovec, 1996: 113). Uspeh deklic pogosto povezujejo z neuspehom dečkov oziroma o njem razmišljajo na ta način, da gre na račun uspeha dečkov. Šole domnevno ne poskrbijo za »tekmovalno « naravo dečkov, deklice so v mehkem izobraževalnem svetu uspešne zgolj zato, ker brezpogojno sprejemajo pravila igre, ipd. Podobno štejejo pomanjkanje konformnosti pri dečkih za bolj zanimivo kot skrb deklic za to, da bi storile tisto, kar je domnevno prav (Gray in Leith, 2004: 4). Zato je treba v tem okviru pozornost posvetiti (tudi) razlikam, o katerih pedagoško osebje meni, da obstajajo. Kodelja, ki izhaja iz pojma pravičnosti v izobraževanju, pravi, da se »diskriminacija deklic $\mathrm{v}$ tem primeru dogaja na podlagi verovanja, da razlike so, in ne na podlagi dejanskih razlik« (Kodelja, 2003: 77). Prav ta vidik je pogosto spregledan oziroma ni problematiziran.

\section{Nekaj o stanju doma in v tujini}

V slovenskem prostoru se je s šolsko prenovo že začel proces, ki v določenem okviru poskuša razvijati občutljivost za problematiko spolnega razlikovanja in/ali diskriminacije v izobraževanju (prim. Kurikulum za vrtce, Bela knjiga o vzgoji in izobraževanju). Bela knjiga denimo govori o enakih možnostih in nediskriminiranosti ter opozarja na dejstvo, da obstajata vsaj dva kurikuluma: formalni in prikriti. Med drugim omenja tudi načine vključevanja v skupnost ter z njimi neposredno povezano vzgojo za strpnost, solidarnost in odgovornost. Hkrati obstajajo študije, ki preučujejo vedenje in vrednotne sisteme mladih v Sloveniji, ki so prav tako indikator učinkovanja prikritega kurikuluma (Ule, 2007, 2008; Jeriček Klanšček in dr., 2007). 
Zelo nerazdelana oziroma pomanjkljivo obravnavana pa ostaja sfera šolskega informiranja in vzgoje mladih na področju seksualnosti in spolnega zdravja. Slovenija je tako poleg Malte edina država, ki ni bila vključena v kompleksno raziskavo o spolni vzgoji v osnovnih in srednjih šolah; ta je bila objavljena leta 2006, opravljena pa je bila s sredstvi WHO v izvedbi mednarodne nevladne mreže International Planned Parenthod Organization (IPPF, 2006). Prav tako je izostala iz pregleda izobraževanja na področju spolnosti in medosebnih odnosov Eurydice iz leta 2009, ki so ga opravili v Veliki Britaniji (NFER, 2009). Ob tem ne bo odveč podatek, da sta $\mathrm{v}$ zajemu in interpretaciji podatkov, ki imata globalne razsežnosti, vključeni dve geografsko-politično primerljivi državi, Poljska in Madžarska. Zanemarjanje pomena teme spolnosti in medosebnih odnosov v izobraževalnem sistemu ima še toliko bolj negativne učinke, saj se otroci in mladi seznanjajo s tema temama predvsem preko medijskih in drugih komunikacijskih, zlasti pornografskih konstrukcij, hkrati pa niso opremljeni za smotrno opredeljevanje do teh podob. Nezadostno je namreč tudi izobraževanje in oblikovanje kompetenc odraščajočih na področju medijev, predvsem v smislu proaktivnega odnosa (kar kampanje za ozaveščanje mladih na tem področju le slabo nadomeščajo, saj predvsem opozarjajo na tveganja). Tako so na primer merila za izbirni predmet na temo medijev v okviru programa osnovnošolskega izobraževanja strokovno, z vidika poznavanja in ustvarjanja medijev in medijskih vsebin, sicer lahko povsem relevantna, a ne upoštevajo (z izjemo nekaj referenc na internet, ki so uvrščene pod poglavje Televizija) kompleksnega pomena in vloge novih medijev v življenju otrok in mladih (gl. Košir et al., 2006). Hkrati se je treba vprašati, v kolikšni meri lahko uporaba generičnega moškega spola, ki je dejstvo omenjene priročniške »vzgoje za medije«, spodkoplje vsako resno obravnavo diskriminatornih vlog in statusov spolov $\mathrm{v}$ informativnih/množičnih medijih (in novih medijih).

Tradicija pretežno feministične literature razkriva, da v večini programov t. i. spolne vzgoje (sexuality education) prevladuje deerotizirana in klinična oblika izobraževanja in da torej umanjka »diskurz želje« (Allen, 2004: 151, in nasl.). ${ }^{2}$ Običajno spolna vzgoja enači spolno zdravje z odsotnostjo spolno prenosljivih bolezni in nezaželenih nosečnosti (pri čemer je razpon sredstev, s katerimi bi to dosegli, širok: od zagovarjanja abstinence do bolj odprtih, »liberalnih« usmeritev in kurikulumov). L. Allen denimo predlaga vključitev diskurza erotike, ki bi vključeval ugotovitev, da so vsi mladostniki/-ice, ne glede na spol in spolno identiteto (transgender,

${ }^{2}$ Terminološko in konceptualno izraz »spolna vzgoja« preizprašava v nadaljevanju. 
intersex, ženske, moški, lezbijke, geji, ipd.), spolni subjekti, ki imajo pravico do spolnega užitka in želje, v tovrstne programe. Vključitev tega diskurza v programe pomeni tudi »ustvarjanje prostorov, v katerih je spolna želja mladostnikov/-ic legitimirana, pozitivno integrirana in postane splošno sprejeta« (Allen, 2004: 152). Ob tem pa je seveda potrebna pazljivost, da diskurz erotike ne prispeva dodatno $k$ heteronormalizirajočim tehnikam, ki predstavljajo heteroseksualnost kot »normalno « in homoseksualnost kot odklon.

L. Allen je opravila raziskavo na vzorcu novozelandskih mladostnikov/ic, v kateri je ugotavljala razmerja med vednostjo o spolnosti, subjektivnostih in praksah. Ugotovila je tudi (kar bržkone ni novozelandska posebnost), da so velika vrzel v mnogih programih že omembe lezbičnih, gejevskih, biseksualnih, transgender in intersex identitet, če pa se homoseksualnost že »pojavi« v njih, potem je to pogosto v povezavi z geji in nevarnostmi aidsa.

Ta tema je tudi v slovenskih kurikulumih za osnovno šolo precej »obrobna « in je že pri oblikovanju kurikuluma povzročila veliko polemik. D. Rédai (2003), ki je raziskovala šolsko prenovo v Sloveniji, je od ene od svojih slovenskih respondentk izvedela, da sta bili pri predmetu družba še posebej problematični temi družine in spolne usmerjenosti. Do zapleta v kurikularni komisiji je prišlo že ob omembi ločitve zakoncev, še bolj pa se je zapletlo ob spolni usmerjenosti. Na Ministrstvo je bila celo poslana peticija, ki jo je podpisalo več kot trideset učiteljev in učiteljic, da naj se tema homoseksualnosti izpusti. Na koncu so jo vendarle vključili, toda bolj kot neobvezno. ${ }^{3}$ Pri predmetu biologija je denimo tudi predviden pogovor o aidsu - to je še posebej občutljiva tema, ob kateri bi didaktična priporočila morala specificirati ustrezen način govora (str. 22), saj se drugače lahko zgodi, da se pogovor o aidsu začne odvijati v okviru protiseksualne retorike. ${ }^{4}$ Podobno velja za obravnavanje spolnih bolezni (str. 33) (Vendramin, 2005: 44). Vprašanje, ki si ga ob podobnih primerih v Združenih državah, Veliki Britaniji in Avstraliji zastavljajo Epstein et al. (2000: 128), je, zakaj

\footnotetext{
${ }^{3}$ Do podobnih ugotovitev sta prišli tudi Komidar in Mandeljc, 2009. Podoben »škandal «se je pripetil bolj nedavno ob predavanju o družinah, ki ga je izpeljal R. Kuhar na domu ene od učenk (na domu zato, ker ga ni smel izvesti v šoli - kljub povabilu in kljub temu, da kurikulum za družbo za četrti razred predvideva pogovor o družinah) (Kuhar, 2010). Npr: med operativnimi cilji je navedeno, da učenci/-ke prepoznavajo vrste družin in razumejo smisel povezovanja v družine. Spoznavali naj bi tudi razlike med ljudmi v skupnosti (tudi po spolu in spolni usmerjenosti).

${ }^{4}$ Kot opozarjajo Epstein et al. (2000), je prav za raziskovanje izobraževanja o aidsu značilen veliko večji občutek za kontekst kot sicer.
} 
je treba tako dominantno institucijo, kot je heteroseksualnost, braniti tako vehementno in s tako visokimi vložki?

Namen »spolne vzgoje«, kot piše L. Allen (2004: 154), v različnih zgodovinskih trenutkih posredujejo javni diskurzi, ki določajo družbene in gospodarske pojave kot »probleme«, s katerimi se je treba ukvarjati. To pa pomeni, da je bila »spolna vzgoja« vse od svojega začetka dojeta kot pripomoček za zaustavitev naraščajočih primerov spolnih bolezni, »promiskuitete «, »seksualne deviantnosti in negativnih učinkov nezaželenih nosečnosti. Rezultat tega osredotočanja na različne »družbene probleme« je bil, da so pozitivno plat želje in užitka odrinili na stran. Pravzaprav je bila želja po zunajzakonski zvezi predstavljena kot temeljni dejavnik, ki je prispeval $\mathrm{k}$ tem problemom. Spolni odnos v nekem trenutku postane sinonimen z reprodukcijo in tu želja ne dobi več prostora (Diorio in $\mathrm{Mu}-$ nro, 2000). Nadaljnja posledica reproduktivnega poduka, »kako semenčica oplodi jajčece«, je ta, da se spolna dejavnost izenači s heteroseksualnostjo, kar vodi v osredotočenje na kontracepcijo, penetracijsko spolnost in nosečnost (Thorogood, nav. po Allen, 2004: 154). In drugič, spolna aktivnost se konstituira kot nevarna, kot $\gg$ tvegan posel «, ker se prioriteta podeli potencialno negativnim posledicam spolne dejavnosti nad pozitivnimi (Allen, 2004: 154). In končno, podobe teles, ki se uporabljajo pri pouku, so medikalizirane, telesa so nekako raztelešena, genitalije označene kot »reproduktivni organi« (ibid.), kar spet potegne pozornost od seksualiziranih zunanjih obrisov telesa $\mathrm{k}$ njegovi reproduktivni funkciji.

L. Allen opozarja (2004: 155, in nasl.), da poseben problem take zasnove zadeva dekleta, ker jim odreka subjektno pozicijo, s katere bi lahko aktivno izbirale (pogosto so predstavljene kot pasivne sprejemnice moške želje, težje naj bi dosegale spolni užitek kot fantje itn.). Poleg tega pa je vključitev diskurza erotike pomembna tudi za fante. L. Allen je s svojo raziskavo ugotovila, da je skoraj tri četrtine fantov v vzorcu svoje znanje o spolnosti pridobivalo v pornografskih revijah, to znanje so označili kot »zelo koristno (medtem ko približno isti delež deklet ni nikoli konzultiral tovrstnih revij). Tako bi vključitev diskurza erotike pozitivno vplivala na (oba) spola, saj bi pri dekletih odpravila morebitno neuspešno posredovanje občutka osebne moči, pri fantih pa pomagala razrahljati izraze hegemonske moške heteroseksualnosti, ki omejujejo alternativne izraze moške seksualnosti, hkrati pa tudi odvzemajo moč njihovim partnerjem. Poleg tega diskurz erotike, ${ }^{5}$ oziroma bolje, seksualnih privlačnosti in užitkov poma-

${ }^{5}$ Erotičnost ima v mladostniškim žargonu (denimo »hot«, »hudo «) in pojmovanju razsežnosti antičnega erosa, vitalne življenjske sile, ki ni nujno povezana z neposrednimi seksualnimi zaznavami in čutenji. 
ga spodbijati diskurze »erotike« v mainstreamovski pornografiji (Allen, 2004: 163).

\section{Otroštvo, mladost, seksualnost}

Tema, ki je relativno neobdelana, je seksualnost v osnovni šoli (Epstein et al., 2000: 133). ${ }^{6}$ Če sledimo zgodovinarjem otroštva in družine ter tezi francoskega zgodovinarja Ph. Arièsa, je nedolžen otrok - nedolžen, ker o spolnosti ničesar ne ve in ker ga spolnost na noben način tudi ne zanima in ne sme zanimati - relativno nova »iznajdba« (Ariès, 1990). Ariès govori o »modernem občutju otroštva«, ki naj bi se začelo uveljavljati nekje v sedemnajstem stoletju kot znamenje posebnega in novega zanimanja za otroštvo. Skupaj s tem zanimanjem pa vznikne tudi neka nova disciplina, katere namen je v prvi vrsti poskrbeti za ohranjanje otrokove nedolžnosti in obvarovati otroštvo pred »umazanostmi življenja, zlasti pred spolnostjo « (Ariès, 1990: 143). Če je bila spolnost dotlej nekaj, kar je nedozorelemu otroku tuje in mu zatorej govorjenje o njej ne more škoditi in ne kvariti njegove nedolžnosti, pa se poslej začne pojavljati, kot zapiše Ariès, ne le zanimanje za otroka, ampak tudi za njegovo nedolžnost, ki bo zdravorazumsko obveljala za bistveno otrokovo lastnost.

V zadnjem času se pojavlja strah, da otroci prezgodaj odraščajo, da »še niso pripravljeni za vednost o spolnosti. Popularna psihologija prav tako pravi, da otroci odraščajo brez otroštva, da jih indoktriniramo s skrivnostmi odraslih, narašča pa tudi tesnoba o spreminjanju oblastnih razmerij med odraslimi in otroki (Buckingham, 2000: 23 in 25).

Ti diskurzi otroške nedolžnosti niso samo škodljivi za otroke, trditev, da vednost o seksualnosti kvari otroke, je tudi globoko protiizobraževalna (Epstein et al., 2000: 135) - otroke namreč seksualnost zanima, diskurze heteroseksualnosti, na katere naletijo na igrišču ali v učilnici, uporabljajo kot vire, iz katerih lahko črpajo pri vzpostavljanju stikov in navezovanju prijateljstev, poleg tega pa sami prinašajo v skupnost različne izkušnje v zvezi s seksualnostjo. Kot je pokazalo obsežno etnografsko delo z malimi otroki na anglo-ameriškem govornem področju, spolna vzgoja ni samo del uradnega kurikuluma, odvija se v skupinah prijateljev/-ic, niansirajo pa jo etnija, razred, spol in $\gg$ mali kulturni svetovi«, ki jih naseljujejo otroci v šoli in drugje (Epstein et al., 2000: 137-138).?

\footnotetext{
${ }^{6} \mathrm{Tj}$. neobdelana v kontekstu literature o spolni vzgoji, ne pa v kontekstu otroške seksualnosti na splošno, kar je precej drugačen problemski sklop.

${ }^{7}$ Navajava nekaj tovrstnih študij (povzeto po Epstein et al., 2000: 138): Ali, S. (2000). »Mixed Race « Children, Identity and Schools. V: Culture, Communication and Societies. London: Lon-
} 
Torej je za oblikovanje ustreznega, relevantnega in posodobljenega kurikuluma za spolno vzgojo izhodiščno treba ugotoviti, da so otroci in mladostniki/-ice podvrženi kompleksnim pritiskom glede na njihovo seksualnost, ${ }^{8}$ še zlasti v povezavi s spolom, etnijo, raso, starostjo, razredom ... Kurikularne inovacije, kot pravijo Epstein et al. (2000: 154), ki bi se naslavljale na denimo homofobijo, ne bodo učinkovite brez zadostnega razumevanja kulturnih svetov specifičnih skupin mladih ljudi v specifičnih šolah. Poleg tega ima vsaka stopnja sistema formalnega izobraževanja svoje specifičnosti, ki dajejo več ali manj prostora različnim različicam seksualnosti. Nekoliko drugače je na univerzitetni ravni, ko mladi ljudje »dobijo družbeno dovoljenje «, da so lahko seksualni, to se skoraj pričakuje kot del legitimne poti v svet odraslih (Epstein et al., 2000: 158). Epstein et al. (2000) ugotavljajo, da je na tej ravni (opozarjava, da trditev velja za angloameriško področje) homoseksualnost nekako bolj »prisotna«, čeprav z vidika heteronormativnosti nič manj sporna.

$\mathrm{Na}$ ravni znanstvenoraziskovalnega diskurza v Sloveniji umanjkanje kompleksne tematizacije oziroma dosedanje pomanjkanje podpore raziskovalnim projektom, ki bi tematizirali spol in spolnost, onemogoča uvid $\mathrm{v}$ obstoječe pogoje za demokratično seksualizacijo mladih in kompleksno razumevanje seksualnega zdravja. Pregledna slovenska strokovna raziskava, ki je zajela kompleksnejšo problematiko spola in spolnosti v sistemih osnovnošolskega in srednješolskega izobraževanja v EU, je bila opravljena v sklopu slovenskega predsedovanja EU. Vsebovala je predvsem pregled stanja, pri čemer Slovenija ni bila posebej tematizirana - nasprotno, dostopni podatki zanjo so bili izjemno pomanjkljivi ali pa so bili, posredovani priložnostno in pavšalno s strani državnih ustanov, nekredibilni (Šribar in Ule, 2008: 24, 55-59).

Na podlagi pričujoče analize izobraževanja, spola in spolnosti z referenco na t. i. spolno vzgojo sva opredelili več področij, kjer ugotavljava po-

don Institute of Education; Connolly, P. (1995). Boys Will be Boys? Racism, Sexuality, and the Construction of Masculine Identities Amongst Infant Boys. V: Holland, J., Blair, M., in Sheldon, S. (ur.). Debates and Issues in Feminist Research and Pedagogy, Philadelphia: Multilingual Matters; Epstein, D. (1995). »Girls Don't Do Bricks«: Gender and Sexuality in the Primary Classroom. V: Siraj-Blatchford, J., in Siraj-Blatchford, I. (ur). Educating the Whole Child: CrossCurricular Skills, Themes and Dimensions, Buckingham: Open University Press; Thorne, B. (1993). Gender Play: Boys and Girls in School, Buckingham: Open University Press; Walkerdine, V. (1997). Daddy's Girl. Basingstoke: Macmillan.

${ }^{8}$ Rezultate ene od novejših raziskav o spolnih praksah v Sloveniji obravnavava v nadaljevanju besedila pod poglavjem »Platforma za izboljšanje otroških in mladostniških kompetenc na področjih spolnosti, nasilja in novih medijev«. 
manjkanje bodisi refleksije bodisi konkretnih analiz, s pomočjo katerih bi lahko oblikovali smernice za prenos v prakso. To so:

- razjasnitev konceptualnih problemov (oblikovanje terminološkega aparata na obravnavanem področju, kjer je Slovenija močno v zaostanku)

- oblikovanje znanstvene platforme za uveljavljanje sodobnega pojmovanja in analize konstrukcij spolne razlike, spolnosti in s spoli in spolnostjo povezanega nasilja, ki omogoča aplikacijo v ukrepe (na primer zakonodajne) na področju vzgoje in izobraževanja

- analiza posameznih primerov obravnave konstrukcij spolov, spolnosti in medsebojne povezanosti spolnosti in nasilja $\mathrm{v}$ učnem načrtu in pri pouku

- analiza normativnih dokumentov EU na obravnavanem področju - soočenje diskurzov, navedenih v predhodnih alinejah: predstavitev podob/konstrukcij spola, spolne razlike, spolnosti, s spoli in spolnostjo povezanega nasilja in zdravja

- ugotavljanje dejavnikov, ki na ravni posameznika in posameznice součinkujejo na reproduciranje represivnih spolnih in seksualnih vlog v okviru VIZ (revščina, pripadnost etnični manjšini, telesni hendikep ...)

- študija primera demokratičnih konstrukcij spolov in spolnosti na področju primarnega in sekundarnega šolstva v državi EU

- oblikovanje platforme za uvajanje sodobnih konceptov na področju spola, spolnosti in spolnega zdravja, nanašajočih se na VIZ, v različne javnosti.

Nereflektirana in nenormirana »spolna vzgoja « v izobraževalnem sistemu v Sloveniji (za preverjanje te teze gl. European Commission Directorate General for Health and Consumer Protection, SAFE Project: A European Partnership to Promote the Sexual and Reproductive Health and Rights of Young People) ima še toliko bolj negativne učinke, saj se, kot že izpostavljeno, otroci in mladi seznanjajo $s$ spolnostjo in se soočajo $\mathrm{z}$ nasiljem predvsem preko medijskih, zlasti pornografskih in drugih komercialnih konstrukcij industrije zabave. Tako posredovane konstrukcije diskriminatornih tradicionalnih spolnih vlog $\mathrm{v}$ spolnosti in odnosih vendarle lahko vodijo v rizično vedenje na škodo otrok in odraščajočih ter na škodo drugih (kljub temu, da gre zelo redko za neposredno oponašanje vedenja). V tem kontekstu bi si morali zastaviti za cilj opolnomočenje, informiranost in osveščenost otrok in mladih na področju (novih) medijev in po- 
sebej tam proizvedenih konstrukcij spolnosti in nasilja. Otroke in mlade je treba spodbuditi, da sprevidijo, kako vsebine v medijih in novih medijih oblikujejo stališča in vedenje tako $\mathrm{v}$ spolnosti kot $\mathrm{v}$ odnosih nasploh. Treba jim je posredovati orodja, s pomočjo katerih bodo lahko namesto ravnanja, ki temelji na predpostavkah, domnevah in »spontanih« željah izbrali delovanje na podlagi informiranih odločitev.

Terminološka platforma: »spolna vzgoja «?

Preden se posvetiva nadaljnji razpravi, se terminološko opredeljujeva do »spolne vzgoje«; sintagma prevzema preteklo poimenovanje zdaj že opuščenega predmeta $\mathrm{v}$ šolskem kurikulumu in je teoretsko preživeta. Sodobni znanstvenoraziskovalni diskurz ponuja možnost ustreznega poimenovanja za označevanje šolskih vsebin na področju spolnosti in z njo povezanih odnosov - ne glede na to, ali gre za enoten predmet ali pa so teme pokrite v okviru predmetov, kot so biologija, etika, sociologija, psihologija in podobno.

V študiji s predlogom indikatorjev na področju družbenih možnosti deklet in deklic, ki je bila napisana $\mathrm{v}$ angleščini in ni bila prevedena, je bil uporabljen izraz sexuality education (Šribar in Ule, 2008: 21). Čeprav lahko termin education dejansko prevedemo zgolj s slovenskim »vzgoja «, pa ima kljub temu širši pomen, saj se pogosteje uporablja v smislu vzgoje in izobraževanja. Ustrezen prevod bi se torej moral glasiti »spolno izobraževanje in vzgoja «. A dokončno oblikovani indikatorji so bili tudi uradno prevedeni zgolj z izrazom vzgoja, čeprav je bilo samo polje razširjeno v skladu $\mathrm{z}$ izvorno konceptualizacijo (angl. sex relationship education, sexuality related education: »spolna vzgoja in vzgoja o medčloveških odnosih «) (UEM, 2008). Kakor koli že, pomenska širitev na področju oblikovanja politik ni prinesla terminološke rešitve glede »vzgoje «. Pogosto ostaja enako neproblematizirana tudi terminologija na področju stroke in znanosti (na primer Jeriček Klanšček et al., 2007: 180).

Vzgoja kot koncept in s tem termin ima močan konotativni pomen, ki se navezuje bodisi na tradicionalno krščansko, natančneje katoliško moralo ali na polpretreklo zgodovino pristopa $\mathrm{k}$ socializaciji otrok in mladine $\mathrm{v}$ okviru socialistično državotvornega državljanstva. Danes pomensko pojem vzgoje v smislu kompleksnega usposabljanja mladoletnih z izobraževanjem in drugimi vrstami usposabljanja nadomeščata izraza razvoj ali spod- 
bujanje kompetenc, ${ }^{9}$ ki pa v funkciji poimenovanja kurikularne snovi praviloma nista najustrezneje zveneči sintagmi.

Evropski primeri v poimenovanju predmeta in obravnavanih kurikularnih vsebin so raznoliki; odsevajo specifično vodilno državno politiko na področju ideologije in etike. $Z$ vidika demokratičnega seksualnega državljanstva so nekateri neizogibno ali potencialno regresivni, na primer zlasti: »izobraževanje in vzgoja za družinsko življenje « (angl. family life education) in »odnosi med spoloma « (angl. relations among member of different sexes) ${ }^{10}$ pa tudi »vzgoja in izobraževanje za življenje « (angl. life skills education). Zgledi so redki, če kot konceptualno usmeritev zastavimo spolnost v kontekstu širših družbenih odnosov: »vzgoja in izobraževanje za spolnost in medosebne odnose « (sex and relationships education), »spolna vzgoja in izobraževanje ter medosebni odnosi « (sexuality education and interpersonal relationships) (IPPF, 2006: 9). Ker gre pri konceptualno ustreznih poimenovanjih za daljši niz besed (do katerega pride s prevodom v slovenščino zaradi angleške besede education, tj. izobraževanje in vzgoja), se ponuja rešitev $s$ skrajšanjem poimenovanja oziroma $\mathrm{z}$ osredotočenjem na samo temo, predmet poučevanja, tj. »spolnost in odnosi«. V opisnem indeksiranju predmeta in vsebin pa lahko vzgojo in izobraževanje/izobraževanje in vzgojo nadomestimo $\mathrm{z}$ razvojem kompetenc; $\mathrm{v}$ tem smislu posredujeva $v$ razpravo predlog opisnega poimenovanja $\gg$ kompetence $v$ spolnosti in odnosih $\ll$.

Aktivnosti in nujnost refleksije na pedagoškem področju in ter načelna izhodišča ravnanja

Osnova za strokovno pedagoško delo mora biti znanstvena obdelava (konceptualna in vsebinsko-metodološka) konstrukcij spolov in medsebojne povezanosti spolnosti in nasilja $\mathrm{v}$ šoli in (novih) medijih. V skladu s tem definirava raznovrstne dejavnosti, ki bodo prispevale $\mathrm{k}$ uresničevanju zastavljenih ciljev:

- razvijanje in ustrezno vrednotenje kurikulov, učbenikov in drugih didaktičnih gradiv

- izobraževanje učiteljev in učiteljic

- prenos načel v prakso ter refleksija in evalvacija tega prenosa

- analiza praks oziroma konkretnih ravnanj v razredu.

\footnotetext{
${ }^{9}$ Kompetence sestavljajo vednost/znanje, spretnosti in odnos, pri čemer se slednji formira $s$ čustvovanjem, vrednotami, motivacijo (Vrečer, 2009).

${ }^{10}$ Pomen neha biti družbeno regresiven, če sexes prevedemo $s \gg$ spoli $\ll \mathrm{v}$ smislu upoštevanja medspolnih (intersex) oseb.
} 
Vse te dejavnosti pa bi v skladu s feminističnim izhodiščem morala prežemati težnja po uveljavljanju »preboja « skozi površino pojavov, kot jih zaznamo na prvi pogled, in ponoven premislek o predpostavkah o $\gg$ naravnih « zmožnostih in značilnostih žensk ter marginaliziranih skupin, skupaj z razmislekom, kako družbeni sistemi uporabijo te zmožnosti in racionalizirajo oblike neenakosti (primer je denimo delitev dela in plačila glede na spol). Pravzaprav so največja ovira za družbeno spremembo rigidne ideje, ki temeljijo na zdravem razumu, oziroma tiste, ki jih legitimira to, kar je »očitno《 ali »naravno« pri ženskah (Penley, 1989).

Napačna in pomanjkljiva vzgoja je že dolgo poglavitni protipol, ki ga feministične teoretičarke postavljajo nasproti mizoginemu argumentu, da ženske so, kakršne pač so, že po naravi. Njihovo bistvo - če lahko v feminizmu uporabimo to besedo - ni neposredno povezano $\mathrm{z}$ biologijo spolnih in reproduktivnih organov. Prej je to njihova »druga narava«, torej nekaj, kar je nastalo iz žensk v družbi, v dolgi zgodovini dominacije pa je postvarelo ... (Bahovec, 1996: 107).

To je konsistentno z geslom $\gg \mathrm{Za}$ navadnim leži nenavadno « (»Behind the ordinary lies the extraordinary.«), ki ga je formuliral Ph. Jackson. Prav Jackson je tisti, ki je »odkril« (se pravi, formuliral) koncept prikritega kurikuluma v svojem delu Life in Classrooms (1968). Jackson govori o več ključnih besedah, ki pomagajo opisati »življenjska dejstva« (to so: množica, pohvala in oblast), ki se jim morajo učenci in učenke, pa tudi učitelji in učiteljice, prilagoditi in ki so vseprisotna v šolskem življenju.

Ob tem je nujno razvijanje zavedanja o prikritem kurikulumu, ki zajema mnoge elemente vzgojnega vplivanja na otroke/mlade, ki niso nikjer neposredno opredeljeni, a so mnogokrat v obliki posredne vzgoje učinkovitejši od neposrednih vzgojnih dejavnosti. Omogoča nam »pokriti« širok razpon vidikov vsakdanjega življenja v vrtcih in šolah - socialna razmerja, vsakdanje prakse, razmerja do vsebin, skupaj s mrežo predpostavk, drž, mnenj in pričakovanj, ki so običajno implicitni in neproblematizirani.

V skladu s tem bi lahko rekli, da je nekakšno temeljno metodološko izhodišče zoperstavljanje ali soočanje uradne različice družbene realnosti, družbenih in političnih razmerij, zgodovine in konceptualnih kategorij z alternativnimi pogledi na družbeno, ekonomsko in politično kulturo (Luke, 1988: 27). Tako mnenja, drže in pojmovanja učiteljev in učiteljic skupaj s kurikulumom, ki vsebuje predsodke, tudi na način spregledovanja, pogosto ovirajo izobraževanje deklic, delujejo proti načelu enakih možnosti in uveljavljajo nereflektirane podobe spolov. To hkrati pomeni, da sta učiteljska interpretacija kurikuluma in interakcija z otroki pomembna de- 
javnika. (Kurikulum s predsodki pomeni tudi gradivo, ki ženske in dekli-

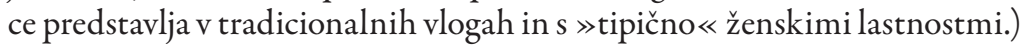

Tovrstna metoda ${ }^{11}$ je hkrati tudi dobro izhodišče za analizo kurikularnih in didaktičnih gradiv ter učbenikov, kjer bi si denimo lahko zastavili vprašanja, kot so:

- ali materiali prelamljajo $s$ tradicionalnimi reprezentacijami moških in žensk (spolov) in spodbujajo drugačne konstrukcije

- kako se spopadajo z zdravorazumskimi predpostavkami

- do kakšne mere so samokritični (tj. do kakšne mere sami predpostavljajo potencialno problematične točke in vprašanja) in proaktivni ... skratka, kako »prevajajo « cilje in prioritete konstatirane enakosti med spoloma v materiale, ki so v rabi, in kako zaznavajo to prevajanje kot interpretativno, kritično in parcialno (prim. Haraway, 1999: 312).

Bela knjiga o vzgoji in izobraževanju v Republiki Sloveniji (Krek, 1995) o tej problematiki $v$ »Uvodu « med drugim pravi naslednje:

Kar zadeva razlike med spoloma, je treba premestiti poudarek s formalnih pravic nediskriminiranosti $\mathrm{k}$ substancialnim pravicam in zagotavljanju enakih možnosti na vseh ravneh sistema vzgoje in izobraževanja. Zato moramo, ko govorimo o pravicah otroka, spregovoriti tudi o pravicah deklic in o protislovnosti ideje o enakih možnostih v neenakem sistemu edukacije, ki na tak ali drugačen način še vedno privilegira pripadnike enega spola. Z uvedbo koedukacije za deklice in dečke je bila odpravljena na zunaj vidna diskriminacija na ravni šolskega sistema, kot »prikriti kurikulum« pa se ohranjajo subtilnejši mehanizmi oblasti, značilni za šolo kot institucijo moderne dobe (organizacija vsakdanjega življenja $\mathrm{v}$ šoli, konkretne prakse in načini poučevanja, komunikacija med učenci in učitelji itd.), ki deklice naučijo, »kako zgubljati«.

A prvi nujni korak je, kot se zdi, sploh napraviti to vprašanje vidno, pa ne le preko nekih splošnih krilatic o enakosti, ki jih najdemo skoraj v vsakem kurikulumu za devetletno osnovno šolo, a so pravzaprav brez učinka in brez konkretnih standardiziranih priporočil res ostajajo le na ravni krilatic - čeprav tudi »Navodila za delo predmetnih in programskih kurikularnih komisij« govorijo o vzgoji za enakopravne odnose med spoloma kot o eni od »medpredmetnih tem, spretnosti in dimenzij v osnovni šoli«, kar je nedvomno pomembna omemba, a sama po sebi ne more zadoščati. ${ }^{12}$

\footnotetext{
${ }^{11}$ Ta metoda je ogrodje, ki ga lahko razvijamo v več smeri: v smeri kritične teorije diskurza denimo.

${ }^{12}$ Za ilustracijo, druge »teme, spretnosti in dimenzije « so: učna tehnologija, prometna vzgoja, zdravstvena vzgoja, okoljska vzgoja, poklicno in izobraževalno informiranje in državljanska vzgoja.
} 
Seveda ni dovolj predstavljati in uveljavljati alternativnih različic realnosti. Vseeno pa je mogoče trditi, da bodo imela gradiva, ki so močno prežeta z družbeno dominantnimi temami, predvidljive učinke na večino učencev in učenk (Diorio in Munro, 2000: 351). Potencial kritike in analize materialov tako na ravni vsebine kot forme je natanko v senzibilizaciji edukacijske zavesti na ideološke prakse - tiste, ki so skrite, ki jih ni mogoče zlahka detektirati in so zato izjemno persistentne.

Prizadevanja za bolj »uravnoteženo strukturiran« kurikulum, kar zadeva enakost med spoloma - kar na primer pomeni, da omogoča obema spoloma, da se identificirata s pozitivnimi sporočili o njiju, da priznava in ceni vrednost posameznikov in skupin, da uravnoteži različne perspektive, da prepleta izkušnje, potrebe in interese obeh spolov -, morajo torej nujno priznati tudi »drugo plat« formalnega kurikuluma, ki je prikriti kurikulum, denimo socialna razmerja, razmerja do tega, kar se poučuje. Zgodovinsko gledano, kot je opozoril tudi M. W. Apple, prikriti kurikulum - tj. nevidno poučevanje o družbenih in kulturnih normah ter pričakovanjih sploh ni bil prikrit. Šole oziroma vzgojno-izobraževalne institucije so bile deloma namenjene poučevanju prav tega, kar danes uvrščamo pod prikriti kurikulum (Apple, 1992: 49). T. i. akademsko vednost (če je o njej sploh mogoče govoriti na tak način) spremlja cel diapazon osebnih, družbenih idr. vednosti. Kurikulum deluje ideološko, a tu ne gre, kot pravi J. Donald, za vprašanje polnjenja glav različnih ljudi z različnimi vsebinami - kurikulum »deluje« tako, da vzpostavlja hierarhična razmerja med različnimi oblikami vednosti in tako generira mrežo subjektivnih položajev v razmerju do teh hierarhij. Potemtakem ne razlikuje samo med oblikami vednosti, temveč tudi med ljudmi (Donald, 1992: 176).

\section{Primer: »spolna vzgoja « v kurikulumu}

Kot pišeta Diorio in Munro (2000: 351) v svoji analizi novozelandskega kurikuluma, so gradiva, ki obravnavajo menstruacijo, zelo obloženi z heteroseksističnimi in hegemonskimi maskulinističnimi pomeni: ženske so obravnavane $v$ okviru svojih reproduktivnih funkcij in $v$ spolnem redu podrejeno pozicionirane. »Ironično je, « pišeta avtorja,

da se poučevanje o menstruaciji osredotoča izključno na reprodukcijo, medtem ko hkrati poskušamo zmanjšati najstniške nosečnosti. Problem najstniške nosečnosti nas je tako prevzel in tako smo usmerjeni v reproduktivne implikacije pubertete, da posvečamo le malo pozornosti temu, da bi dekletom pomagali 
pridobiti samozavest zaradi njihovih spreminjajočih se teles v tem pretežno nereproduktivnem obdobju njihovega življenja.

Spolni vzgoji je namenjen del tudi v slovenskem kurikulumu za biologijo. ${ }^{13}$ Človek je zasnovan kot biološko, psihosocialno in kulturno bitje. Predvidena je tudi razprava o aidsu in spolno prenosljivih boleznih. Ker je to morda še posebej občutljiva tematika, bi jo morala didaktična priporočila podrobneje obdelati oziroma predvideti način govora o njej. Podobno velja za učni cilj, ki se ukvarja s hormonskimi spremembami med menstrualnim ciklusom in njegovim vplivom na fizično in psihično stanje ženske (Verčkovnik et al., 2002: 25). Menstruacija je torej predstavljena kot vir higienskih težav na individualni in družbeni ravni. Ta tema je denimo še posebej pomembna za nediskriminatorne prakse v razredu, saj se učenci in učenke učijo, da menstruacija lahko povzroči, da so dekleta slabe volje, fantje pa s sklicevanjem na menstruacijo ponižujejo dekleta (Diorio in Munro, 2000: 349, 351).

Po drugi strani - to je na tem mestu treba omeniti - je odsotnost družbene etiologije predmenstrualnih in menstrualnih pojavov pogosto tudi prisotna $\mathrm{v}$ medicini in naravoslovnih znanostih na splošno in ni lastnost samo tega kurikuluma.

\section{Uradna vednost}

Poleg razgradnje zdravorazumskih predpostavk, ki onemogočajo kritičen razmislek in ki utrjujejo tradicionalna in neposodobljena pojmovanja, tako $\mathrm{v}$ navezavi na vsebine, ki zadevajo konstrukcije spolov in spolnost, kot na družbo, kulturo in naravo, je treba izpostaviti tudi problematizacijo t. i. »uradne vednosti« in s tem razvijanje kritične naravnanosti do »univerzalnih resnic « (v okviru naše problematike so na primer aktualna predvsem »dejstva o spolnosti in reprodukciji ter zasnova spolne vzgoje kot kontroverzne ipd.).

Ob tem se je treba zavedati, da je že sam izbor vsebin in materialov problematičen. Pravzaprav smo vedno nepopolni in pristranski: izbor nikoli ni nevtralen, ampak se oblikuje iz kulturnih, političnih in tudi ekonomskih napetosti in kompromisov, ki organizirajo, združujejo in razdružujejo ljudi. Skupna kultura tako nikoli ne more biti zgolj razširitev na vse družbene skupine, ne le vključitev dotlej odsotnih reprezentacij družbenih skupin, ampak je njen predpogoj ustvarjanje pogojev, ki bi vsem družbenim skupinam omogočali ustvarjati pomene in vrednote (Apple, 1992: 70), po-

${ }^{13}$ To ni analiza kurikuluma, ampak samo primer, ki ga navajava zaradi ilustracije problematike. 
gojev, ki bi omogočili tudi konceptualno delo in rekonstrukcijo občih pomenov. Ob razmišljanju o uradni vednosti je torej treba priznati, da je izbor vedno že tudi izključitev oziroma da vsebuje tudi beline, prazna mesta, ki so prav toliko indikativna kot tisto, kar je vključeno, kar je eksplicitno povedano. Kurikulum je del selektivne tradicije, ki lahko na primer marginalizira ali podreprezentira ženske, ljudi drugih ras ali druge, ki so manj vplivni, oziroma njihove družbene in kulturne prispevke.

Rešitve, ki bi lahko odpravile vsaj nekatere stereotipizacije, predsodke in pristranskosti v zvezi s spolom in spolnostjo, so raznolike, čeprav neredko tudi problematične, ker pogosto poenostavljajoče predpostavljajo, da v naši, »patriarhalni«, civilizaciji moški načrtno zatirajo ženske in da je rešitev v (zavestnem) osveščanju zatiranih. Poenostavljene interpretacije predstavljajo tu enodimenzionalno različico družbe, v kateri gre za nekakšno teorije zarote, načrtno vzdrževano nevednost, možnost neproblematičnega osveščanja in neproblematične narave naše realnosti. To sva problematizirali že zgoraj, kjer opozarjava, da je diferenciacija v dva epistemološka sistema, tistega, v katerem prevladujejo patriarhalni interesi, in drugega, ki je povezan z izkušnjami žensk, sporna in poenostavljujoča (in da za zdaj feministična teorija tudi ne ponuja enoznačnega odgovora).

»Površinska« analiza kurikuluma oziroma pregled stanja z vidika spola, kulture, stereotipov ipd. se v določeni meri pokriva z zgodnjo stopnjo feminističnega raziskovanja, ki so ga opisali tudi kot iskanje »izgubljenih« žensk«, »izgubljenih « ženskih imen in s tem domnevno uravnoteženje kurikuluma in izobraževalnih vsebin nasploh. Ob strani pa tako ostajajo bistvena vprašanja o »spolno zaznamovanih [engendered] vednostih, praksah in kompetencah«, ki bi morala biti osrednja pri kurikularnih reformah, ki naj bi na novo premislile vednost in ne le producirale »gender inclusive « različice (npr. Luke, 1993: 118). Z drugimi besedami, kot pravi D. Haraway (1991: 301), morali (morale) bi destabilizirati naše predpostavke o »božjem pogledu «, ko se vidi vse od nikoder, ko je vid neskončno mobilen, neskončen. V destabilizaciji ali vsaj poskusu destabilizacije gre za boj za občo vednost, za to, kaj bo obveljalo za racionalne opise sveta, za to, kako sploh gledati. Če ponoviva: videnje je vprašanje moči gledanja (ibid.: 307).

\section{Koncepti pismenosti}

Pismenosti danes ni mogoče več definirati zgolj kot univerzalne, kulturno nevtralne veščine oziroma veščine, ki jo sestavlja hierarhija konstitutivnih spretnosti, kot veščine, ki jo z ustreznimi metodami preprosto »vlijemo« $\mathrm{v}$ učenca ali učenko in tako dobimo pismeni subjekt brez vseh raz- 
lik. Taka tehnokratska različica ironično utiša in racionalizira vsako razliko ter ji podeli videz univerzalnosti, ahistoričnosti in ideološke korektnosti (Luke, 1993), hkrati pa implicira, da je pismenost neke vrste avtonomna spremenljivka, ki jo je mogoče potegniti iz konteksta in izolirano preučevati.

Zdi se, da je pismenost tako v svetu kot tudi pri nas (p)ostala aktualno geslo, ki zakriva in zanikuje številne družbene probleme in nasprotja. Vanjo so se nekako »vtihotapili« različni družbeni in kulturni dejavniki, kar pomeni, da gre za več kot za ravni pismenosti ali rezultate na različnih testih (različnih) pismenosti. $\mathrm{O} \gg$ učinku pismenosti« - pismenost definirava kot umeščeno družbeno prakso - ne moremo razmišljati ločeno od družbenih dejavnikov (denimo življenja v mestu, kompleksne birokratske kulture, tehnoloških sprememb itn.), ki oblikujejo prakse pismenosti, in nasprotno, ki jih oblikujejo prakse pismenosti.

Preučevanje pismenosti je mogoče začeti s prepoznavanjem nekakšnega presežka skrbi, ki vznikne ob rezultatih različnih študij in testiranj, ki kažejo, da ravni pismenosti strmo upadajo. To nedvomno niso samo abstraktne zagate. Tovrstna razmišljanja lahko pomagajo oblikovati teoretsko podstat, na katero se lahko opre praktični angažma, skupaj z resno refleksijo rezultatov, predstavljenih skozi različne statistike. Ne trdiva seveda, da je pismenost nepomembna ali da nepismenost ni ovira, gre le za to, da je njeno stopnjo in njen vpliv težko predpostaviti in izmeriti. Dominantne paradigme je smiselno dopolniti z novimi raziskovalnimi definicijami in alternativnimi pogledi.

V vzgojno-izobraževalnem delu je torej treba posodobiti različne definicije pismenosti (medijske, novomedijske) in omogočiti tudi refleksijo njim inherentnega odnosa do »tradicionalne «, bralne ipd. pismenosti; refleksijo ustvarjanja pomenov in prepoznavanje razmerja med pismenostjo in kulturo, interpretacijo in izkustvom. Tu poudarjava vlogo šole kot mesta prenašanja vednosti in vključevanja v kulturo ter mesta proizvajanja vednosti in proizvajanja kulture. Tako pismenosti ne moremo ločevati od družbenih in institucionalnih struktur, tu govorimo raje o pismenostih, ki jih definirajo pomeni, ki jih producirajo, in družbeni interesi, ki jim služijo.

Današnji upad pismenosti, ki ga tako neučinkovito merimo in razumemo (kar ne pomeni, da problemov ni), morda ni taka velika sprememba za ustreznejšo analizo bi bilo treba vsaj toliko upoštevati spremembe v komunikaciji, kulturne spremembe $\mathrm{v}$ odnosu do medijev in tehnologije kot rezultate na testih funkcionalne pismenosti ali prizadevanja po vrnitvi $\mathrm{v}$ 
preteklost (Graff, 1995: 312-313), kjer, kot se zdi, vedno manjka konkreten zgodovinski referent. Zato problematizacija pismenosti zahteva premislek vsaj o naslednjem: kako se spreminja razumevanje pismenosti, kakšno je razmerje med praksami in govorom o teh praksah, kakšne so omejitve današnjih konceptualizacij ter kakšni so morebitni novi miti o pismenosti in njihovo razmerje do družbenih, kulturnih, političnih idr. pogojev.

$\mathrm{V}$ tem smislu odpirava pot refleksiji, ki bo uporabna tako širše kot v edukaciji:

- kako medijske in novomedijske vsebine in storitve učinkujejo in oblikujejo percepcijo stvarnosti s strani otrok in mladih, s poudarkom na vztrajnosti tradicionalnih pomenov »ženskosti « in »moškosti«

- kako medijske in novomedijske vsebine ter storitve učinkujejo na sposobnost otrok in mladoletnih, da lahko razvijejo in ohranjajo zdrave odnose in seksualnost

- kako pokazati na močno sposobnost oziroma kompetenco za kritični odnos do medijskih in novomedijskih vsebin in odnosov, ki se vzpostavljajo v okviru novomedijskih storitev.

\section{Mesto feministične teorije v edukaciji}

Teoriziranje spolne razlike je kompleksno in dinamično, kar velja tudi za polje edukacije. Feministična teorija (ali teorije) o edukaciji (hkrati s tem izrazom se ognemo problematični feministični pedagogiki) in širše lahko pomembno prispeva h konfrontaciji nekaterih temeljnih kategorij in pojmov (denimo »objektivnost « ali »univerzalna« resnica). Teorija edukacije, ki se ne meni za feministične kritike in analize spola, »dela slabo uslugo obojim, ženskam in moškim, ker ne prepozna načinov, kako je mogoče obogatiti obstoječe pedagogike« (Jackson, 1997: 466) - predvsem z vprašanji o oblastnih razmerjih in epistemološkimi vprašanji, ki zadevajo izjave o resnici ter posredovanju in konstituiranju vednosti.

Feministično delo (torej tudi teorijo) je pomembno podpirati - a ne kot »dodatek « taktikam in strategijam, ki si prizadevajo za večjo socialno pravičnost, ne s spolom kot dodatkom t. i. rasi in razredu, osrednji trojici v tematiki socialne pravičnosti. Ženske študije in/ali feministična teorija tako ne govorijo le o zanimanju za spolno razliko, ampak se ta (paradigmatska) razlika povezuje tudi z vprašanji drugih razlik ali različnosti med ljudmi - oziroma se labko povezuje. Nedvomno je tu potencial za tako povezovanje, odstiranje samoumevnosti, povezanih z različnimi družbenimi skupinami, seveda pa to ni nujno: feminizmi (in feministke) lahko tudi marsi- 
kaj spregledajo, ne reflektirajo ali se pustijo ujeti v omejitve takšne ali drugačne samoumevnosti. R. Felski v svoji analizi feminizma in postmodernizma pravi, da nemara potrebujemo »večopravilnost «, sčimer ima v mislih raznolike in pogosto nasprotujoče si tokove kulturnega izraza in pripadnosti, ne da bi izgubili pogled na širše družbene determinante neenakosti. Vendar razmišljati o feminizmu kot $\gg$ zgolj o še eni lokalizirani subverzivni strategiji v postmoderni dobi trivializira in nevtralizira moč feministične kritike in jo reducira na zgolj še en glas v 'veselem politeizmu' jezikovnih iger« (Felski, 2000: 206-207). ${ }^{14}$

Osredotočanje na kategorijo spola, ki ji spričo feministične perspektive podeljujeva osrednje mesto, danes ne izključuje analize drugih družbenih razlik, kot so denimo razred, etnija, rasa, religija, seksualnost. Večina avtorjev/-ic danes dela s pojmi multiplicitnosti in različnosti ter z očmi multipozicioniranih in multivokalnih subjektov raziskuje kompleksnost družbenih formacij. Spol pa ostaja izhodišče in tista točka, ki omogoča razmišljati o postopkih, ki vzdržujejo razliko (Arnot in Mac an Ghaill, 2006: 4), in ob njem razvita raziskovalna orodja so pomembna za razumevanje diskriminacij in razlik ob različnih družbenih oseh. Splošno in hkrati temeljno vprašanje pa je, kako reflektirati asimetričnost procesov, ki enemu spolu dajejo možnosti, drugemu pa ne (z zavedanjem, da smo se spet ujeli v dihotomijo, ki pa jo je tudi treba začeti presegati), kako se izogniti temu, da bi jemali kulturne zgodbe za univerzalne realnosti (Haraway, 1997: 60).

Feministična pedagogika kot na učenca ali predvsem učenko osredotočeno poučevanje je - če spregledamo raznolikost njenih definicij - sporno polje feministične refleksije; ali pa morda polje, kjer manjka določene refleksije, denimo refleksije o njenih omejitvah. Toda dejansko obstajajo izključujoče prakse, ki učencem in učenkam onemogočajo »partnerstvo v vednosti«. Obstaja pa tudi specifičen neksus razmerij, ki konstituirajo učni proces (Currie, 1992: 359) - in privilegirani vlogi, ki jo ima učitelj/ica v njem, se nemara ni mogoče izogniti, lahko pa razvijemo občutljivost za učinke moči, ki jih ta vloga omogoča. Ali drugače: težnja ali zahteva po odpravi oblastnih oblasti je kar tvegana, saj tako zlahka spregledamo, kako močna in prevladujoča so ta razmerja (Penley, v Bahovec, 1992: 264).

\footnotetext{
${ }^{14}$ To je hkrati tudi komentar N. Fraser in L. Nicholson na omejitev Lyotardovega opisa »jezikovnih iger (nav. po Felski, 2000: 210, op. 42).
} 


\section{Značilni primeri iz šolskega okolja}

Sklepni del sklopa, namenjenega posebej spolu, spolnosti in s spolnostjo povezanega nasilja v vzgoji in izobraževanju, posvečava predstavitvi primerov iz šolskega (in tudi vrtčevskega) okolja. V skladu z etičnimi načeli raziskovanja je urejena tako, da osebe, ki pripovedujejo, niso prepoznavne, zgodbe pa ne (preveč) nazorne, saj bi slednje lahko imelo predpisovalno funkcijo glede na »usodo « vpletenih v sam primer. O dogodkih in njihovem največkrat družinskem zaledju so poročale vzgojiteljice, učiteljice/ji in profesorice/-ji v okviru projekta Pedagoške fakultete Univerze v Ljubljani in Ministrstva za šolstvo in šport RS »Profesionalno usposabljanje strokovnih delavcev v vzgoji in izobraževanju v letih 2008/2011 na področju socialnih in državljanskih kompetenc « in v tematskem sklopu Prepoznavanje in preprečevanje nasilja. Gre za vzgojno-varstvene (vrtci) in vzgojno-izobraževalne ustanove (osnovne in srednje šole) na Severnem Primorskem, Dolenjskem, Štajerskem in Gorenjskem, Koroškem in v Prekmurju. Med predavanji in delavnicami ${ }^{15}$ so udeleženke pripovedovale ${ }^{16}$ o dogodkih na šoli, ki so se zgodili njim samim ali pa njihovim kolegicam in kolegom. Nekatere zgodbe se nanašajo na domača okolja učenk in učencev pa dijakinj in dijakov, šola je bila v teh primerih samo mesto, na katerem so otroci preko s spolnostjo in nasiljem označenega vedenja izražali simptome slabe družinske situacije. Primeri, ki jih povzemava (s prepoznavanjem njihove paradigmatskosti), so bili v šolah razumljeni kot problemi, za katere bi bile potrebne večje strokovne kompetence pedagoškega kadra.

Kljub temu, da so delavnice vključevale oblikovanje idej, strategij in načrtov za reševanje problematike, se je vedno znova izkazalo, da tudi ustanove, ki bi morale prevzemati del odgovornosti v težjih primerih, tega ne počnejo v zadovoljivi meri (centri za socialno delo, policija, sodišča). V primerih, ko starši ali skrbniške osebe botrujejo ali so botrovali neželenemu vedenju otrok, pa je bil izpostavljen manko moči šole. Obenem ni enotnih usmeritev šol glede razumevanja spolov, spolnosti in s spolnostjo povezanega nasilja. Zato se zdi bolj smotrno kot navajati »recepte« posredovati pojmovni okvir za sodobno koncipiranje spolov, spolnosti in nasilja, vključno z medijskimi in novomedijskimi konstrukcijami (kar je tudi namen pričujoče monografske publikacije).

\footnotetext{
${ }^{15}$ Predavanja z delavnicami so bila izvedena od januarja 2009 do junija 2010; skupaj je šlo za devetnajst gostovanj po šolah (v enem primeru tudi v dijaškem domu), ki so trajala štiri, šest ali osem šolskih ur.

${ }^{16}$ Večina navzočih so bile ženske.
} 
Iz empirične perspektive se vedno znova izkaže, da pomen znanja, ki bi ga morali sistematično posredovati zaposlenim $\mathrm{v}$ šolah in vrtcih, narašča komplementarno s pojavnostjo diskriminatornih in nasilnih vêdenj in problematiko diskriminatornega odnosa samega pedagoškega kadra. V ilustracijo poleg beleženja pripovedi o primerih posredujeva tudi opažanja reakcij udeleženk in udeležencev predavanj in delavnic.

Pomudimo se najprej pri samih poročilih o dogodkih, povezanih s konstrukcijami spolov in medsebojne povezanosti spolnosti in nasilja $\mathrm{v}$ šolskem življenju in $\mathrm{v}$ (novih) medijih. V srednjih šolah so udeleženci in udeleženke poročali o naslednjih ponavljajočih se dogodkih:

- dijaki (fantje) na šolskem računalniku iščejo (žanrske) pornografske slike

- profesorica/-or stopi v razred in zaloti dijake pred računalniškim zaslonom, na katerem so pornografske fotografije

- dijaki razširjajo pornografsko gradivo po računalniku ali mobilnem telefonu

- dijaki in dijakinje izražajo nespoštljiv ali spolno izzivalen odnos do profesorjev in profesoric

- dijaki in dijakinje prevzemajo nasilno in pornografizirano vedenje v medsebojnih odnosih

- dijaki pred telesno vzgojo snemajo dekleta v garderobi z mobilnim telefonom in potem pošiljajo fotografije vrstnikom (enako se dogaja tudi v osnovnih šolah).

V osnownih šlah in vrtcih problematika, povezana s komercialno in pornospolnostjo in nasiljem ter njunim uprizarjanjem $\mathrm{v}$ (novih) medijih ali skoznje, ni bistveno drugačna, vendar pa ima pedagoški kader več vpogleda v domače okolje. Žal ponavljajočih se dogodkov, katerih pojavnost je vendarle odvisna tudi od starosti otrok, ne moremo razvrstiti po starostnih skupinah, ker so bila predavanja z delavnicami organizirana tako, da se jih je večinoma udeležil celoten učiteljski zbor, v mnogih primerih pa so se jim pridružile tudi vzgojiteljice iz bližnjega vrtca.

Med najbolj razširjenimi pojavi, povezanimi s konstrukcijami pornospolnosti in seksualiziranega nasilja, je izpričano soočenje otrok $s$ t. i. erotičnim (porno chic) gradivom med likovnim poukom, ko se na šolskih klopeh znajde dnevni in revijalni tisk. Sledi razširjanje pornografskega gradiva s strani dečkov in pornografizirano ali drugače spolno izzivalno vêdenje deklet. Vzgojiteljice in učiteljice so večkrat poročale tudi o pojavnosti ma- 
lih Lolit. Nekaj primerov se nanaša na seksualizirana in žaljiva sporočila skupine fantov. Nekajkrat je omenjen tudi primer, da dekle z mobilnim telefonom pošlje fantu do pasu golo fotografijo v prepričanju, da sta (bosta?) v intimnejšem razmerju; fant pa jo razpošlje po vrstniški mreži.

Najbolj izstopajoči posamezni primeri na vseh stopnjah vzgoje in izobraževanja so bili velikokrat povezani s situacijo v (nefunkcionalni) družini:

- primer dečka, ki v šoli riše po zgledu pornoscen; izkaže se, da je bil prisiljen konzumirati pornografijo skupaj z očetom

- primer hendikepiranega, permisivno vzgajanega dečka, ki razširja pornografijo na nasilniški način (bullying)

- primer dekleta, ki dobiva žaljive mms-je od osebe z lažno identiteto

- primer deklice, ki je prevzela vlogo Lolite, eden od staršev pa za spolno nadlegovanje obtoži vzgojno-izobraževalno ustanovo

- primer dekleta pornografiziranega, sodobnega vamp vêdenja, ki je $\mathrm{v}$ neprestanem konfliktu s šolskim okoljem, nekaterim vrstnicam pa je vzor; oče je odsoten, mati se ni več pripravljena soočati s hčerinimi problematičnimi situacijami

- dva primera očitnega in grobega spolnega nadlegovanja, obakrat gre za odnos deškega spodkopavanja poklicne in osebne integritete oziroma kar dostojanstva učiteljice/profesorice

- primer večje porno chic fotografije, ki jo je nekdo nalepil na omaro na šolskem hodniku.

Simptomatični odzivi

$\mathrm{Na}$ primere medijsko in kibernetsko zaznamovane spolnosti in nasilja, ki so se zgodili v vrtčevskem ali šolskem okolju, so se učiteljice/učitelji in profesorice/profesorji odzvali na različne načine, od zelo informiranih in kompetentnih do takih, ki so pomenili minimaliziranje problema v smislu, da gre za »naravno«, »normalno« vedenje. Vendar se je izpostavilo kar nekaj vêdenj, ki so pogosta in značilna za majhno zanimanje za problematiko spola v šolskem okolju. Kot že nekajkrat konstatirano, sta vladajoči matrici medsebojne povezanosti spolnosti in nasilja povezana s pričujočimi kulturnimi konstrukcijami prav skozi diskriminatorne tradicionalne spolne vloge. $V$ tem smislu so najpogostejši odzivi na medsebojno povezanost med spolnostjo in nasiljem interpretirani, kot da so dekleta tista, ki izzivajo, fantje pa se »zgolj« odzivajo. Izpričano dejstvo je najizrazitejše v obravnavi stila oblačenja deklet $\mathrm{v}$ šolskih prostorih, kar samo po sebi sicer 
lahko pomeni ustrezno temo, vendar ni smotrno, da je problematizirana le zunanjost deklet $\mathrm{v}$ šoli. Mladostniški kulturni trendi se prav tako nanašajo na fante, pri čemer je tudi njihov (subkulturni) slog lahko neprimeren za šolsko okolje (naj navedeva le primer skejterske mode). »Nova spolna izzivalnost deklet« je del zelo pogostega pedagoškega prepričanja o drugačnih razmerjih moči med spoloma in omalovaževanja ali neprepoznavanja vztrajne diskriminatornosti v konstrukcijah spolov, ki dobiva vedno nove izrazne oblike. Tako se zdi, da moč deklic narašča, fantov pa upada. V razmerju $s$ »spolno izzivalnimi« dekleti se jim pogosto pripisuje bodisi vloga odzivnih, bolj tradicionalno usmerjenih fantov ali pa se interpretirajo kot preplašeni in nemočni pred spolno nenasitnostjo deklet. Ta medspolna heteroseksualna ekonomija nima bistvenih novih značilnosti in ne zamaje resno tradicionalnih spolnih vlog $\mathrm{v}$ spolnosti in s spolnostjo povezanem nasilju. Le da številnejša dekleta uprizarjajo Lolite ali pa tradicionalno spolno izzivalno držo opremljajo z novimi elementi po vzoru vladajočih, »moških « vrednotenj seksualne uspešnosti; oblačilna manira v kombinaciji tesno oprijetih, odprtih oblačil, ki pa vendarle omogočajo svobodno in neobremenjeno gibanje, je iz te perspektive videti simptomatična (prim. Allen, 2008: 436). Naj poudariva, da sprememb v spolnih vlogah in statusih ne zanikava, vsekakor pa preizprašujeva njihovo temeljnost.

$\mathrm{V}$ pedagoški sferi sva na obravnavanem področju, če povzameva, našli pet modelov pojmovanj spolnih vlog in statusov v razmerjih moči v povezavi s spolnostjo in nasiljem ter vladajočimi medijskimi in novomedijskimi konstrukcijami:

- moški in ženske postajajo enakopravni, pri mladih je to že drugače, moški kuhajo, staršujejo, ženske so uspešne v svojih poklicih in znajo tako kot moški poiskati užitke

- moški in ženske še vedno nimajo enakega položaja in enakih možnosti v družbi, to je prav dobro razvidno iz medijskih in drugih kulturnih konstrukcij spolov

- pri mladih je prišlo do obrata vlog, moški niso več »pravi«, dekleta so nespodobno, neprimerno agresivna $\mathrm{v}$ spolnosti in izstopajoča po vedenju nasploh

- vloge moških in žensk so naravne, takšne kot so, vsako obremenjevanje $s$ tem je neumnost

- ukvarjanje s konstrukcijami spolov in spolnosti je vredno omalovaževanja. 
Vendar ta prepričanja po pričakovanju niso homogena. V okviru navedenega projektnega dela je bilo na primer pogosto iz ust iste osebe slišati oboje: konstrukcije spolov v medijih, zlasti na področju seksualnosti, so diskriminatorne, položaj moških in žensk ni enak, in na drugi strani: dekleta so seksualno tako agresivna, da se jih fantje bojijo. Da ne gre le za ambivalence, ki se tičejo pojmovanja razlik v dogajanjih med (odraslimi) moškimi in ženskami in mladimi fanti in dekleti, pričajo nekatera opažanja vedenja udeleženk projektnih predavanj z delavnicami. Lastno vêdenje in interpretacija določenih dogodkov, $\mathrm{v}$ katere so bile vpletene, sta bila $\mathrm{v}$ nasprotju z izpričano opredelitvijo do spolov, spolnosti in nasilja. Najbolj indikativna sta bila primera spolnega nadlegovanja učiteljice in profesorice $s$ strani učenca/dijaka. Nista ga razumeli kot demonstracijo in pridobivanje spolne moči fantov, kot interpretira tak obrat šolske hierarhije v hierarhijo spolov na škodo žensk v pedagoškem poklicu V. Walkerdine (Walkerdine; Nayak in Kehily, 2008: 124). Nasprotno, kljub umevanju, da gre za spolno diskriminacijo in obliko seksualnega nasilništva, je bila njuna interpretacija deloma $v$ registru diskriminatorno tradicionalnega razmerja med spoloma v seksualnosti. Obe sta postavili pod vprašaj svoj videz, se vprašali, koliko sta sploh »vredni« spolnega nadlegovanja s strani učenca in dijaka.

Opisanim ambivalencam, ki preprečujejo ustrezne odzive na primere spolno nasilnega vedenja, s poudarkom na vlogi (novih) medijev, se pridružuje še dodatna oteževalna okoliščina. Govor o spolnosti in spolno/seksualno zaznamovanem nasilju ni »udomačen «, zadrege pa ne gre pripisati zgolj verskemu, krščanskemu okolju, kot je opisala »stanje duha« ravnateljica ene izmed šol. Velik vpliv imajo vladajoča mnenja, navsezadnje tudi tista, ki so povezana z marginaliziranimi spolnimi (transspolnimi) in seksualnimi subjektiviranji. Tu zelo prisotno ponotranjenost predpisanih spolnih vlog in heteronormativnosti bi sprejemanje »drugačnih« ospoljenj in spolnih usmerjenosti gotovo zmehčalo, četudi v primeru tolerance do homoseksualnosti, lezbištva in domačega primera transspola ne tako temeljito, da bi to ustrezalo normam demokratičnega državljanstva. 


\section{Problematika}

porna in drugih

konstrukcij sprege

seksa in nasilja skozi

nove medije

emeljno raziskovanje konstrukcij spleta spolnosti in nasilja v tradi-

cionalnih in novih medijih in v razmerju do družbeno-kulturnega vzpostavljanja otroštva in mladosti zahteva iz naše perspektive multidisciplinarno znanstveno platformo. Heterogenost pristopa sovpada s tematsko kompleksnostjo, dotikamo se fenomenov in tematik spolov, spolnosti, nasilja, otroštva in odraščanja, medijev in novih medijev pa tudi samih komunikacijskih vsebin in storitev ter z njimi povezanih tveganj. Slednje lahko definiramo šele, ko razpolagamo z različnimi konceptualizacijami, opredelitvami in klasifikacijami. $S$ tem namenom opozarjamo na strokovne oziroma strateške definicije (pravo v medsebojni poveznosti z zakonodajo in nadzorom ter regulacijo), empirično sociološke in kulturološke opredelitve ter prijeme same pornografske in druge zabavniške industrije. Pomembno pa je ugotoviti tudi, s kakšnimi poimenovanji se na obravnavane vsebine odzivajo informativni mediji (Šribar, 2006).

Vsebine in odnosi, ki jih problematiziramo, so ključno povezani z mediji; sam termin je mnogopomenski, zato ga bova v nadaljevanju definirali. Mediji in novi mediji, vsebine in odnosi, ki se vzpostavljajo skoznje in tudi skozi novomedijske storitve, so med seboj povezani oziroma tako tesno prepleteni, da - to velja še posebej za nove medije - niso razvezljivi. Občestvo, na katerega se obravnavane vsebine ali storitve posredno ali neposredno naslavljajo (v najini tematizaciji), je opojmljeno kot otroštvo in mladost; slednja je strukturirana kot deklištvo in »deštvo «/fantovstvo oziroma vključuje »mlade ženske « in »mlade moške«. Bolj kot opredelitve te družbene skupine in njenih podskupin v socialni psihologiji, empi- 
rični sociologiji in kulturologiji ali antropologiji se osredotočava na multidisciplinarni pristop $\mathrm{v}$ šolskem polju in $\mathrm{v}$ ugotavljanju tistih kulturnih trendov vsakdanjega življenja, ki so povezani z novomedijskimi konstrukcijami spolov. Tako denimo anglosaški viri opozarjajo na mladost v globalnih in lokalnih razmerjih novih medijev in jo sokonstruirajo kot »tehno « mladost. V tem okviru se oblikujejo različne konceptualizacije, na primer »spalnična kultura«. Sintagma se nanaša na dekliško preživljanje časa v izolirani zasebnosti, kjer je komunikacijska tehnologija tako v partnerski vlogi (nadomešča druženje) kot v vlogi posrednice/akterke v vrstniških odnosih in stikih (Nayak in Kehily, 2008: 55).

Polje, na katerem spoznavava problematiko pornovsebin in drugih konstrukcij medebojne povezanosti spolnosti in nasilja v segmentu otrok in mladine, je polje odnosov, ki jih feministična teorija in normativni dokumenti EU povezujejo s konceptom škode; slednjo razumeva v okviru njene strukturne narave in ne v smislu individualne škode, tj. škode, ki se utegne zgoditi posameznemu otroku ali mladostnici, mladostniku.

\section{Opredelitev in značilnosti novih medijev}

Še tako razširjeni objekt ali tema raziskovanja je lahko obenem tudi predmet temeljnega nesporazuma, ki botruje ambivalencam v raziskovalnih rezultatih različnih raziskav. Izhodiščna zadolžitev v obravnavi »vmesnikov« (Strehovec, 2007: 17) med imenovanimi vsebinami/storitvami in njihovimi porabniki in porabnicami naj bo zato definicija novih medijev in predstavitev sinonimov. Ugotoviti morava, da že sam termin medij producira veliko različnih pomenov, tudi če z njim mislimo zgolj nosilce informacij in komuniciranja (in se pri tem ne spuščamo na druga področja človeškega življenja, kot so umetnost, psihologija, alternativni kulturni trendi, tj. duhovnost ipd.). V tem smislu najpogostejša, poljudna raba besede zadeva vse, kar »nosi« določene vsebine in odnose, naj so ti informativnega, komunikacijskega ali tržnega/komercialnega značaja. Reflektirana raba termina pa se ozira na pravni, medijski in teoretski diskurz. Pravna in medijska stroka v Sloveniji opredeljujeta medije v prvi vrsti kot posrednike informacij; iz tega zornega kota so mediji praviloma informativni (tako je določeno tudi v trenutno še vedno veljavnem zakonu o medijih iz leta 2006). Glede na (znanstveni) sistem razvrščanja, ki ga uporablja J. Strehovec, bi tovrstno opredelitev medijev lahko poimenovali tradicionalni informativni množični mediji (sledeč avtorjevemu zgledu sem umeščamo dnevni in informativni periodični tisk, radio in televizijo, gl. 2007: 217). Strehovec med tradicionalne množične medije uvršča tudi film in fo- 
tografijo. Med novimi mediji pa našteje spletne strani, računalniške igre, hipertekst, iTV, resničnostni TV-šovi, digitalni film, DVD, mobilni telefon, wap, blog, GPSL; opredeli tudi njihove skupne značilnosti: logika podatkovne zbirke, digitalnost, interaktivnost, povezljivost, mobilnost, individualiziranost, imerzivnost (ibid.). Že navedba televizijskih resničnostnih šovov implicira nadaljnjo avtorjevo tezo, »remediiranje « tradicionalnih množičnih medijev. Sodobna razprava o novih medijih pravzaprav le pogojno lahko še vključuje natančno in ostro delitev med tradicionalnimi (množičnimi) mediji in novimi mediji, tako pač moramo razumeti trditev, da danes ne gre več za televizijo (in na primer film) na eni strani in internet na drugi, temveč za, denimo, »televizijo skozi medmrežje « ali film skozi »mobilne zaslonske naprave« (mobilni telefon, i-pod ...) (ibid.: 28, 118).

Če je novomedijska vsakdanjost daleč od še vedno veljavne slovenske medijske zakonodaje, ${ }^{1}$ pa tržno usmerjeni/dirigirani normativni dokumenti EU (ki po defaultu vključujejo nekatere norme iz registra človekovih pravic) uspešneje »sledijo « tehnološkim trendom. Prejšnja t. i. televizijska direktiva se je transformirala $\mathrm{v} \gg$ direktivo avdiovizualnih medijskih storitev«, ki s poimenovanjem kaže na inkluzivni značaj z vidika novih medijev. Te relativne ažurnosti ne bi smeli razumeti skozi populistično prispodobo hoje pravnih norm za tehnološko dejanskostjo. Kot razmišlja B. Luthar v svoji tematizaciji mobilnega telefona, je tehnologija nadaljevanje (oblastniške) politike z drugimi sredstvi; hkrati navaja avtorje in avtorice, ki tudi sam tehnološki razvoj povezujejo z izvajanjem oblasti (Luthar, 2007: S12-S13). Normativno usmerjanje novih medijev potemtakem določa tudi smer tehnološkega razvoja novih medijev, za katerega pa ni videti, da se dogaja na strani človeške integritete in vsaj delnega ohranjanja individualnih in »nekontaminiranih « medosebnih prostorov. Tehnološki razvoj, ki gre v smeri varovanja človekovih pravic, slej ko prej ostaja predvsem stvar deklarativnih politik in mnogo manj politično uravnavane prakse (naj navedemo na primer sisteme tehnološke zaščite in nadzora dostopa na splet z vidika človekovih pravic otrok).

V nekaterih naddržavnih dokumentih, ki pa so napisani iz perspektive varovanja človekovih pravic in se dotikajo bodisi dostopnosti novih medijev s strani marginaliziranih družbenih skupin ali pa razvijajo strategije za preprečevanje spletnih tveganj, se uporablja še en izraz s približno enakim pomenom, kot ga imajo »novi mediji $\ll$. Komisija za status žensk, ki deluje v okviru ekonomskega in socialnega sveta ZN, je na 51. seji (2007) predstavila že sprejeti dokument o preprečevanju vseh oblik diskriminacije in na-

\footnotetext{
${ }^{1}$ Tu je treba postreči z datacijo oddaje teksta: 30. september 2010.
} 
silja nad deklicami in dekleti (Agreed conclusions on the elimination of all forms of discrimination and violence against the girl child) in med tezami, kako izboljšati dekliške življenjske možnosti, navedla tudi »pospeševanje dostopnosti informacijske in komunikacijske tehnologije (IKT) «.

Ne glede na natančnost in rabo nanizanih izrazov je za nove medije določujoče medmrežje in njihov avdiovizualni značaj. Teoretska refleksija novih medijev z vidika človeških čutil in telesa je nominalnemu dodala še drugačne uvide. Ti se dotikajo človeških utelešenj in vpetosti $\mathrm{v}$ družbeno strukturo skozi predmetnost novih medijev, denimo taktilnost teksture prenosnega računalniška, upravljanje kurzorja z miško, kadriranje druge osebe skozi ekran na telefonu in podobno. Kibernetsko »povečana resničnost «, »bližina, ki raste proti opazovalcu«, pri čemer je ta obenem tudi potencialni producent kibernetskih vsebin (Strehovec, 2007: 37, 188, 219), sta koncepta, ki pojasnjujeta prepletenost človeških življenj in življenja tehnoloških objektov. ${ }^{2}$

$\mathrm{Na}$ našem interesnem področju, tj. področju odraščanja, gre za nove načine utrjevanja tradicionalnih diskriminatornih razmerij med spoloma skozi novomedijsko predmetnost; ti vključujejo tradicionalno samopotrjevanje dečkov ali fantov z nasilnim obnašanjem in ustvarjanje videza seksualne razpoložljivosti s strani deklet. Naj si na tem mestu osvežimo spomin $\mathrm{z}$ referenco na uničevanje razreda na eni izmed slovenskih srednjih strokovnih šol, ki so ga storilci posneli s kamero mobilnega telefona. Zastavlja se vprašanje, ali bi do destruktivnega dejanja brez tega »dokumentiranja« sploh prišlo in če bi, ali bi sploh v tolikšni meri. Obenem se je z distribucijo posnetka to nezakonito dejanje »raztegnilo «, dobilo dodatno dimenzijo. Razmerje šola in učenci je $\mathrm{v}$ tem primeru postalo bolj dramatično, nikakor pa ni izšlo iz matrice. Fantje so v določeni fazi odraščanja želeli nasilno izkazati svoj enakovrednejši status v razmerju do šole kot ustanove $\mathrm{z}$ (relativno) avtoriteto. Konsistentno z vladajočimi predstavami so ga razumeli kot konstitutivnega za (tradicionalno) ospoljenje v moškost. Obenem so ga verjetno - glede na to, da so bili posnetki distribuirani po vrstniški mreži in da so bili potem konec koncev prikazani tudi na televiziji - erotizirali, ga povezali s spolno močjo. Raziskovalki J. Pilcher in I. Whelehan v interpretaciji svoje raziskovalnega primera trdita, da fantovska produkcija moči spola oziroma maskulinosti poteka tako, da morajo fantje izkazati samoobladovanje oziroma obvladovanje emocij ob grobih dogajanjih (Pilcher in Whelehan, 2004: 117, 120). Nasprotnik je bila tudi v tem primeru šola; ta poleg družine v času odraščanja predstavlja poglavitno instanco omejeva-

${ }^{2} \mathrm{Za} \gg$ živost stvari« cf. Luthar, 2007: S12. 
nja, zatiranja. Kljub temu, da je upor pričakovani element v določenih dobah otroštva in odraščanja, je njegov (destruktivni, nasilni) način konstruiran, kulturno vpisan v »maskulinizacijo « vsem tožbam o nasilju v šolah navkljub in neodobravanju le-tega. Zdi se, da z novimi mediji dobiva nov zagon, saj ima njegov učinek, »moška slava«, vse večji doseg.

Drug primer, ki se zdi z obravnavanega vidika kompleksen in primeren za interpretacijo, je (tu že opisan) ponavljajoči se dogodek, ko dekle pošlje razgaljeno fotografijo fantu, običajno sošolcu ali vrstniku iz šole v upanju, da bosta vzpostavila intimnejše razmerje, fant pa pošlje fotografijo naprej prijateljem. Gesta, ki se je $\mathrm{z}$ dekličinega vidika nanašala na intimen medosebni prostor, je bila zlorabljena za fantovsko dokazovanje spolne uspešnosti.

Tu je medij prav tako pogoj možnosti za zlorabo (posnetek in pošiljanje fotografije) in del zlorabe/nelegalnega dejanja samega (nadaljnja neželena diseminacija fotografije). Eden izmed komentarjev v pedagoškem segmentu dobro ilustrira heteroseksistično paradigmatskost primera ne glede na novomedijsko ozadje zgodbe. Dekliško dejanje (pošiljanje razgaljene fotografije) je bilo opredeljeno kot nepremišljeno, fantovsko (razširjanje fotografije) pa kot premišljeno: dekle se »ni zavedalo«, fant pa se »je zavedal, kaj dela«. Poteza deklice je razumljena v sferi trpnosti in morda tudi romantizirane neozaveščenosti, fantovo ravnanje pa je v pridobivanju spolno dominantne moškosti dobilo strateško dimenzijo, pri čemer ni odveč poudariti, da je obče priznana vrednota obvladovanja v opisani razlagi na strani fanta ne glede na to, da je njegovo dejanje nelegalno, dekličino pa je gesta legitimne intime, četudi bi utegnil kdo preizprašati njen značaj z vidika dostojnosti ali na primer dostojanstva. ${ }^{3}$

Očitno je, da novi mediji ne načenjajo temeljne družbene strukture, $v$ našem okviru žensko, dekliško/moških, fantovskih odnosov in hierarhičnega obrata med odraslimi in odraščajočimi v izobraževanju, ki se lahko zgodi na polju spola in spolnosti. Zdi se, da so novi mediji prej vir dodatnih zapletov v obstoječih matricah kot demokratizacije, a naj pri tem vendarle opozorimo, da je predmet naše obravnave omejen, ne nanaša se na celovito vlogo in pomen novih medijev v družbi in posebej v odraščanju. Kljub temu je prav vztrajati pri zadržku do vseh neproblematiziranih, poljudnih slavljenj novih medijev in njihovih potencialov v razvoju družbe, še zlasti z vidika spolov, spolnosti in nasilja.

${ }^{3} \mathrm{~J}$. Strehovec med razpravo o novih družbenih segregacijah, do katerih prihaja skozi nove medije, omenja tudi »kibernetski mačizem« (2007: 191). 


\section{Koncept spolov ${ }^{4}$}

Na tem mestu se vračava $\mathrm{k}$ izhodišču, na kratko in deloma ponovno namreč opredeljujeva tri temeljne koncepte najine refleksije; nanašajoči se termini so vključeni v tematsko opredelitev (spol, spolnost, nasilje). Koncept spol/gender se je sprva nanašal na družbeno konstruiranost spolov v razliki od biološkega ženskega in moškega spola (ang. sex); naknadno je bilo razgrajeno tudi samo pojmovanje biološkega telesa, ki naj bi bilo naravno in samoumevno dualno, moško in žensko (t. i. spolni dimorfizem). Razlog je bil v spoznanju, da je tudi biologija »zainteresirana «, tj. prežeta z oblastnimi razmerji. Danes v feministični teoriji prevladuje razumevanje, da so tudi telesa sama spremenljiva glede na kulturna in družbena okolja ter tokove, zato jih je možno razumeti zgolj v medsebojni povezanosti »biološkega/naravnega in družbenega/kulturnega« (Moi, v Beasley, 2005:14).

Aktualna vloga koncepta spola kot gender je v miselnem zaobjetju vseh, ki se ne prepoznajo znotraj vladajočega preskriptivnega, tj. predpisovalnega moško-ženskega kategoriziranja in karakteriziranja (t. i. spolni stereotipi), hkrati pa tudi ne pojmujejo spolnosti v okviru diskriminatorne heteroseksualne matrice ali vladajočih oblik homoseksualnosti in lezbištva. $\mathrm{V}$ odnosu do prevladujočih medijskih in drugih komunikacijskih konstrukcij spolov, spolnosti in spolno zaznamovanega nasilja so distancirani; hkrati vsebine, ki so tako glede spolnih kot tudi seksualnih identitet (bolje subjektivacij) sodobnejše, ostajajo stvar margine (tako kot njihovi konzumenti in konzumentke) in zato težje dostopnejše in manj vplivne.

Teoretski met diferenciranih ospoljenj oziroma kontinuiteta spola/gender je vprašljiva, če jo razumemo predvsem $s$ strateškega mesta kot demokratizacijo identitetnih politik ali kot uresničevanje končnega cilja - formiranje diskurzivnega mesta, kjer naj bi spol in spolnost pomenila samo relativno poljubno uprizarjanje zunanjosti in telesnosti. ${ }^{5} \mathrm{~V}$ okviru pričujoče študije se spol/gender nanaša predvsem na družbeno strukturiranje spolov, torej na »gender relacije« (Connel, v Beasley, 2005: 11), skozi katere se individuum lahko vzpostavlja kot ospoljeno bitje družbe in kulture. Ključni moment je strukturna odprtost koncepta spola/gender za spre-

\footnotetext{
${ }^{4}$ Koncept spola se nanaša na družbeno in kulturno konstrukcijo spola, ki vključuje tudi »naravni« spol (ang. sex). Razlago sodobnega koncepta spola in spolnosti sva v okviru štirih temeljnih konceptov za razumevanje konceptualizacije gender objavili že v predhodnem tekstu (Šribar in Vendramin, 2009), vendar v krajši različici. Tu objavljava izvorno, daljšo verzijo, ki sva jo morali zaradi zahtev uredništva monografske publikacije Brezspopada: kultur, spolov, generacij skrajšati. 5 Telo je v tem kontekstu razumljeno v svoji podložnosti želenim spremembam, v razmerju spolov in seksualnosti je »plastično $\ll$.
} 
membe; ospoljenega posameznika in posameznice ni zunaj subjektivacije, ki je proces, tj. subjektiviranje iz ozaveščene spolne perspektive (Braidotti, 2001: 396). Ospoljenje/engendering je tudi dejavnost v okviru izobraževalnih politik in praks. Kompetence na področju enakih možnosti spolov ali človekovih pravic žensk in deklic si je težko predstavljati in jih formirati brez osebne vpletenosti oziroma individualnega razmisleka o lastnem ospoljenem statusu in vlogi v družbi, in to tudi na področjih, ki iz te perspektive še niso bila preizprašana.

\section{Koncept spolnosti}

Feministične razprave in študije o seksualnosti so praviloma povezane $s$ pojmovanjem moči. V sedemdesetih in osemdesetih letih preteklega stoletja, ko se je širila vednost o hierarhičnem razmerju med ženskami in moškimi, se je diskusija na področju seksualnosti osredotočila na spolno nasilje. Teoretska razpravljanja in družbena dogajanja v preteklem poldrugem desetletju pa so postavila v središče homoseksualnost in lezbištvo ter odvzela pozornost $s$ problematike heteroseksualnosti v diskriminacijskih spolnih razmerjih; izjema so ostale tematizacije eksplicitnih oblik spolnega nasilja in nasilne spolnosti v okviru normirane homoseksualnosti, heteronormativnosti.

$\mathrm{Z}$ vidika feminističnih obravnav se je prikazovala razlika med »prej« in $\gg$ sedaj«, razlika med preteklim nasprotovanjem spolnosti in aktualno afiniteto do nje (prim. Beasley, 2005: 122). Taka historična opredelitev feminističnega odnosa do seksualnosti v spolnih razmerjih je shematska in ne ravno ustrezna. Osredotočenje na tematizacijo oziroma problematizacijo spolne želje omogoča natančnejši historični vpogled. Niti v odporu proti spolno diskriminacijskim oblikam seksualnosti spolna želja ni bila zanikana, prav tako ne njeno udejanjanje; razmislek in razgraditev sta veljala izbiri objektov spolne želje in njenemu modusu v primeru, ko se je ta vzpostavil skozi spolno diskriminacijsko, predvsem pornografsko simbolizacijo in imaginacijo. Želja je bila dekonstruirana, a nato tudi praviloma rekonstruirana bodisi v smeri izbire istospolnih objektov ali pa k različnim, inovativnim oblikam heteroseksualnih spolnih vêdenj in dejanj. Zato tudi je $\mathrm{v}$ delu zlasti lezbičnega feminizma veljal odpor do regulacije pornografije, saj je obveljalo mnenje, da se z omejevanjem pornografskih vsebin oži tudi prostor za medijske in druge kulturne konstrukcije spolnosti zunaj dominantne, normativne heteroseksualne matrice (Greif, 2009).

Vladajoča spolna hierarhija v seksualnih razmerjih se s prodorom teoretskih diskurzov in medijskih konstrukcij homoseksualnosti in lezbištva 
ni destabilizirala. Vprašanje hierarhij se zastavlja tudi v okviru novih alternativnih oblik spolnosti. Diskurz queer utemeljuje tezo o fragmentaciji in subvertiranju enovite normativne moči v spolnosti (Beasley, 2005: 126), kar lahko pomeni možnost védnosti in praks, ki ne vključujejo absolutnih hierarhičnih pozicij moči/nemoči oziroma aktivnosti/pasivnosti in obvladovanja/podrejanja, temveč menjavanje pozicij. Vendar je opisana pretočnost, menjavanje položajev, ki utegne načeti vztrajno hierarhijo v seksualnih razmerjih, $\mathrm{v}$ heteroseksualnem spolnem vêdenju še težje dosegljiva kot pri drugačnih spolnih usmeritvah. Normiranje moških in ženskih pozicij $\mathrm{v}$ spolnosti $\mathrm{v}$ skladu $s$ pripisanimi moškimi in ženskimi lastnostmi je namreč dojeto kot naravno. $\mathrm{Ob}$ tem so morebitne novosti, spolna agresivnost $\mathrm{v}$ drži deklic in žensk, $\mathrm{z}$ lahkoto integrirane $\mathrm{v}$ tradicionalno spolno paradigmo, zlasti v marketinškem diskurzu (ki je dominanten). Prav pornografizacija spolnosti in druge oblike komercialne seksualnosti tudi sokonstituirajo »izzivalno « spolno vedenje; slednje je skozi svoj žanrski, pornografski zgled speto s podobami spolno razpoložljivih žensk in $s$ tem ujeto $v$ ideologijo naravne ženske pasivnosti, ki ima lahko tudi agresivne oblike izražanja (angl.passive aggressive).

\section{Konceptualizacija nasilja}

Sodobna socialna psihologija govori o novih pojavnostih nasilja, nikakor pa ne o njegovem upadanju, sublimaciji. Problematizacija tega družbenega fenomena je pogosto povezana z obravnavo njegovih (novo)medijskih konstrukcij. Interpretacije samega fenomena nasilja segajo do vse bolj prikritih oblik (običajno gre pri tem za nasilje diskriminatornega govora/izražanja). Hkrati pa postaja sam javni govor v pomenu vladajočega medijskega diskurza mesto vse bolj perfidnega nasilja. Poleg skrajno nazornih prikazov nasilja se tako širijo tudi navidezno sprejemljive ali spregledane oblike. Med slednje sodi t. i. porno chic (»erotika«). Razširjenost konstrukcij nasilja v kulturi, predvsem komercialnih, pa ni zgolj stvar hiperpotrošniške in neoliberalne družbe; tako kot samo nasilje jih spodbujajo ekonomska kriza in spremljajoči pojavi, kot so revščina in splošna družbena kriza (prim. Ule, 2009: 267).

Raziskovanje povezave med konstrukcijami nasilja in nasilnimi dejanji daje ambivalentne rezultate glede neposrednega prenašanja vzorcev nasilnega vedenja $\mathrm{v}$ življenjsko prakso, precej konsenza pa obstaja pri interpretaciji, da uprizarjanje nasilja utrjuje stališča in odnose, ki ga podpirajo. M . Ule med dejavniki medijskih konstrukcij nasilja, ki so v tem smislu še posebej škodljivi, navaja nekaznovanost za nasilje, nekontekstualizirano nasi- 
lje (nasilje ni uprizorjeno kot neprimerno), fokusiranost na nasilje, vsakdanjost nasilja in pogostost njegovega prikazovanja (ibid.: 285). Enako kot za konstrukcije nasilja nasploh velja tudi za uprizarjanje nasilja, povezanega $s$ spolnostjo. $\mathrm{V}$ tem smislu je sporna zlasti pornografija, ki določene geste ali prizore, ki sicer sodijo v register nasilja, prikazuje kot del spolne igre. Povedano velja za vse pornožanre, vključno z navidezno povsem benignimi.

A vrnimo se $\mathrm{k}$ fenomenu nasilja. UNESCO je s pomočjo Inštituta za raziskovanje nenasilnega reševanja konfliktov (Institut de Recherche Sur la Résolution Non-violente des Conflicts - IRNC) izdal publikacijo, ki obravnava nasilje v šolskem oziroma izobraževalnem okolju. J. M. Muller v nasprotju z mnogimi socialnopsihološkimi študijami opredeljuje nasilje $\mathrm{v}$ razliki od agresije. Slednjo razume kot življenjsko silo, silo samopotrditve, prvega pa kot silo smrti. Kot nujni sestavni del človeškega življenja pojmuje konflikt (ki ga je treba prepoznati in z njim upravljati) in ne njegovega nasilnega razreševanja. Nasilje mora opredeliti žrtev, sicer se kaj lahko opravičuje s pomočjo želenega cilja; nasilje, četudi gre za njegove manj opazne oblike, na primer diskriminiranje v jeziku, praviloma pomeni zlorabo, žalitev, brutalnost oziroma krutost in destrukcijo (2002: 11-24).

$\mathrm{Za}$ razliko od tematiziranja posameznih primerov nasilja (subjektivno nasilje), ki običajno razburka medijsko vsakdanjost in javnost, je za naše razumevanje nasilja primernejša družbeno kritična perspektiva, ki nasilje prepoznava kot integralni element obstoječe družbene strukture. Strukturno nasilje, ali če povemo s S. Žižkom, »sistemsko, ,objektivno“ « nasilje je v interakciji s subjektivnim in simbolnim nasiljem in je slepo v sledenju logiki kapitala (2007: 13-14). »Zlo« potemtakem presega posamezno osebo in situacijo. Pričujoča interpretacija ohrani konsistentnost tudi v aplikaciji na t. i. tvegana razmerja novih medijev iz perspektive otrok in mladih. Kot da se vse argumentacije v prid delujoči regulaciji (natančneje koregulaciji) potencialno škodljivih vsebin ustavijo pred silo kapitala industrije zabave; ta posamezne subjekte pornografizacije in razširjanja konstrukcij nasilja v družbi konstituira zgolj kot delčke neustavljivega mehanizma porabništva. A defenzivna drža, temelječa na sicer povsem ustreznem razumevanju delovanja kapitala pri obnavljanju obstoječih diskriminatornih razmerij v družbi, spregleduje dvoje; prvič, da je kapital vpleten v razmerje z vladajočimi razredi/elitami ${ }^{6}$ in drugič, da strukturna narava nasilja ne odvezuje od osebne odgovornosti individuov, vpetih $\mathrm{v}$ pridobitništvo na račun bodisi finančnih in drugih prebivalstvenih margin (otrok, mladih, žensk ...).

\footnotetext{
${ }^{6}$ Vladajoči razred ima v tem kontekstu manj opraviti s politiko kot z družbenoslojnimi, spolni-
} mi, etničnimi itd. elitami. 
Nasilje pornoželje

»Zakonitost svobodnega trga« in »enake možnosti različnih diskurzov« na področju konstrukcij spolnosti in nasilja sta ideologema, del zavajajoče argumentacije. Načela svobodnega izražanja namreč ni možno udejaniti, če se ne upoštevajo razmerja moči med različnimi družbenimi skupinami in se šibkejšim ne podeli moči ali ne ustvarja pogojev, na podlagi katerih bi lahko uveljavili svoj govor. Predstava, da komercialne oblike spolnosti (zlasti porno) in nasilja ustrezajo človeški naravi, pomeni racionalizacijo motivov pridobitništva in vzdrževanja obstoječih družbenih razmerij na področju spolov in spolnosti. Nasilje je samo eden izmed možnih, a ne nujnih izrazov človeške tesnobe in strahu pred drugimi ter inherentnih konfliktov. Kar pa se spolne želje tiče, pornografska želja je specifičen kulturni konstrukt in ima performativni značaj; to pomeni, da se skozi kulturne fantazme oziroma pornoscenarije vpisuje $\mathrm{v}$ individualizirano željo, ki je »moška«. Niti ortodoksnemu psihoanalitskemu, freudovskemu pojmovanju ni možno pripisati verovanja v obstoj univerzalno ospoljene »ženske« in »moške « želje. Freud željo prav tako razume v njeni konstruiranosti skozi kulturo (kolektivne fantazme), pri čemer je gon njen (brezoblični energetski) vir (Freud, 1987: 18, 25, 75, 137).

Pornografija in tudi dominantne oblike konstrukcij nasilja reciklirajo in vzdržujejo že obstoječo kulturno konstituirano željo. Njena »narava« je falocentrična in nasilna, hkrati pa poblagovljena, če uporabimo tezo enega najpomembnejših sodobnih teoretikov (Jameson, 1992: 11). Podobe, bolje zapovedi s strani podob seksa in nasilja se zaradi svoje komercialne, povsod prisotne, neizogibne pojavnosti vkorporirajo v sama telesa, kot pravi Foucault, brez nujnih postaj skozi zavest (1986: 186). Moč kapitala in ospoljene dominacije izza uprizarjanj seksa in nasilja postane »meso«. Vsako nasilno ali/in pornografizirano seksualno delovanje tako postane potrditev vladajočega diskurza »pornoseksa in nasilja«, če parafraziramo znanega angleškega kulturologa R. Williamsa (prim. Foucault, 1986: 41; Williams, 1997).

\section{$\gg$ Tvegana razmerja«: medijske vsebine in novomedijska nadgradnja}

V izhodišču bova razgrnili argumentacije za opredelitev komercialno seksualnih in posebej pornografskih in drugih seksualizirano nasilnih medijskih in kibernetskih snovi in odnosov. V nadaljevanju bova predstavili poimenovanja, ki so se uveljavila na različnih področjih. 


\section{Temeljne opredelitve}

Dominantni (mainstream) pornožanr tolmačiva v okviru družbenega statusa in vlog spolov ter imanentnega razmerja moči, ki je hierarhično in razvidno iz skrepenelih pasivnih in aktivnih tradicionalnih ženskih in moških pozicij (MacKinnon, 1993: 24; Itzin, 2001a: 70). Tudi psihoanalitsko feministična interpretacija pogleda $\mathrm{v}$ pornoseksualnih razmerjih je v tem paradigmatskem okviru (Brown, 1981). Ženska pasivna pozici$\mathrm{ja}, \mathrm{v} \gg$ feminizmu in psihoanalizi« artikulirana kot $\gg$ biti falos «, in moška aktivna pozicija, koncipirana s sintagmo »imeti falos «, se v pornu udejanjata že v sami pojavnosti žanra, v njegovi konzumpcijski razsežnosti (telo pornoakterke in »moški« pogled, tudi v redkejših primerih, ko je pornokonzumentka ženska). $V$ dveh prevladujočih, najširše diseminiranih podžanrih, »mehkem « pornu in porno chicu, so akterke pretežno ženske, moški pa večinsko sestavljajo ciljno skupino. »Biti falos« je, kot nakazano, na ta način preveden $\mathrm{v}$ pornografsko pozicijo biti gledana, $\gg$ imeti falos $\ll$ pa $\mathrm{v}$ pozicijo gledati. Nasilje je $\mathrm{v}$ tem razmerju lahko povsem nezaznavno, reducirano na posedovanje skozi pogled (prim. Strehovec, 2007: 184) in inertnost ali celo neizogibnost položaja, na katerem je ženska akterka konstruirana v prepuščenosti poizvedujočemu, preiskujočemu, oblastnemu pogledu. Naj poudariva, da gre za pozicije, ki niso nujno povezane z moškimi in ženskimi utelešenji. Če je ženska tista, ki s pogledom meri pornotelo, to lahko počne v dveh funkcijah: $v$ funkciji aktivne ženske, ki spreobrača spolno vlogo v spolnosti (na primer $\gg b u t c h \ll v$ nekaterih lezbičnih razmerjih, ki se neposredno referirajo na heteroseksualno matrico), ali pa v funkciji »feminilne«, »prave« ženske, ki ugiba o svoji vlogi tako, da se gleda skozi »moške « oči. Tu je vsekakor treba tudi pripomniti, da javno mnenje in tudi mnogo strokovnih diskurzov ne loči med ženskimi in moškimi pozicijami/vlogami in utelešenimi ženskami in moškimi. V aktualnem trenutku je to razvidno predvsem v neznanstveni javni obravnavi možnosti homoseksualnega in lezbičnega starševstva. Materinska vloga je poistovetena z ženskami, očetovska z moškimi.

Predstavljeno izhodišče za razumevanje pornorelacij in z njimi utrjujočih se tradicionalnih vlog spolov je smotrno umestiti v širši okvir kulture, kjer neposredno vstopanje v nekakšen nov modus delovanja ali sprejemanja ni možno. Možna ni niti parodija bivanjskega principa porabniške odtujenosti kot dominantnega modusa življenja; želja po novem (tudi novih artefaktih) se udejanja le še kot pastiš, ponovitev, kjer je preseganje oziroma nadgradnja zgolj navidezna (Jameson, 2001: 24-25). V teh pogojih ni 
uveljavljenih možnosti za reflektirano, predvsem pa živeto distanco do pornoparadigme. Zato se ne vsiljuje le pornografija niti se ne vsiljuje le paradigma pornospolnosti. Moč-oblast na polju seksualnosti se udejanja skozi konzumpcijo spolnosti s papirnato materijo (MacKinnon, 1996) ali s plastično otipljivostjo ekrana, daljincem in diletantizmom, ki je značilnost žanra (Melendez, 2004: 403-406). Pornoseks presega seks s tehnologijo posredovanih občutkov, skratka projekcijo doživljanj pornokonzumenta (ali redkeje konzumentke) v pornotelo starlete. Telo konzumenta ali konzumentke je odprto za diktat medija ( $\mathrm{v}$ širšem pomenu besede) pornografije (ibid.). Dejanje opisanega seksa je v sodobnosti velikokrat javno, pred izložbami trafik, pri listanju pornorevije, povezovanju na mobilne portale $\mathrm{z}$ »erotičnimi« vsebinami ali pa denimo skozi avatarja $\mathrm{v} \gg$ drugem življenju« (»second life «) ali pri aktivnem spremljanju akterja v resničnostnem šovu.

Pornovsebine se ne morejo konzumirati zunaj zaznavanega ali nezaznavnega seksualnega odziva; tudi slednji se hoteno ali nehoteno prolongira $\mathrm{v}$ povnanjenem seksualnem dejanju. Fiziologija je pač konstitutivna sestavina žanra. Vključena raven telesa, užitek ali pričakovanje užitka še okrepi diskriminatorno tradicionalno zasedbo spolnih vlog v spolnosti, ki se ji pornografija le izjemoma izogne, njene dominantne oblike pa praviloma ne. Pornonorme se vtiskujejo na telesni, imaginarni in simbolni ravni; ženska podreditev v uprizarjanju pornoseksualnosti že implicira (moško) akcijo in $s$ tem sokonstituira dominantna diskriminacijska spolna razmerja (Keppeler, 2001: 91, 93). Tako kot vse sfere hiperpotrošnje tudi seksualnost postane nemožna izven normiranih občutkov. Kar argumentira Jameson v zvezi s konzumpcijo materialnih dobrin, češ da ta ne more biti drugega kot »psevdodogodek « (Jameson, 2001: 60), v enaki meri velja za spolnost.

$\mathrm{Na}$ tem mestu si dopustiva ne povsem znanstven pristavek po zgledu J. Butler, ki v tematizaciji konstruiranosti biološkega telesa poljudno navaja zagato biologije $s$ kromosomsko »pravo moškostjo « (Butler, 2001). V skladu z biologijo človeka je center za seksualno odzivnost v možganih v neposredni bližini centra, ki upravlja agresivnost. Ker v »normalni « zreli spolnosti nobeden od seksualnih gonov ni izključen, naj bi bila mera agresije dejansko imanentna lastnost seksualnosti. ${ }^{7}$ Pozicija na mestu aktivne-

${ }^{7}$ Tu misliva s Freudom, ki oralni gon povezuje z agresijo, z željo po nasilju nad drugim človekom (1995: 76). Kot je smiselno razumeti to trditev, nasilno dejanje ni nujnost, saj agresija lahko najde drugačne poti, najboljši primer je na primer aktiven odnos do drugega telesa, posedovanje skozi konsenzualno spolno željo po telesu drugega ali druge. 
ga/agresivnega člena (ali obratno, pasivnega/trpnega) ne bi bila problematična, če bi se prehajalo med tema pozicijama, tj. objektom/spolno použitem in subjektom/(po)uživalcem. Toda hotena ali nehotena konzumpcija porna neprestano in enako $\mathrm{v}$ zasebnosti kot na javnih mestih zapira ženske na pasivne, mazohistične pozicije objekta za (po)uživanje in moške na agresivne, sicer zakrite sadistične pozicije (po)uživalca. Argument naravnosti, normalnosti teh skrepenelo moško in žensko zasedenih pozicij zanikajo tako empirična sociologija z raziskovanjem seksualnosti žensk (Hite, 2006) kot tiste sodobne feministične teoretizacije, ki izhajajo iz koncepta instance spola in/ali spolne maškarade in jih poznamo pod nazivom študij queer.

Kako se pričujoča paradigma bere na posameznih porno- in porno chic ter pornografiziranih materialih, je možno uvideti z lingvistično in semiotično analizo. Sami po zgledu C. MacKinnon in J. Butler uporabljava orodja iz lingvističnega in semiotičnega kanona (Austin, 1990; Benveniste, 1988); gre za pomembne spoznavne opore pri razumevanju in tudi soustvarjanju kulture spola in seksualnosti onkraj diskriminatornih tradicionalnih koncipiranj.

Feministična teorija performativnosti spola (Butler, 2001), ki se je razvila vzporedno tudi v okviru feministične refleksije pornografije (MacKinnon, 1996: 16-22, 121, op. 31), naju je neodvisno od podobnih ugotovitev $\mathrm{v}$ ameriških in britanskih študijah porna privedla do orodja, $s$ katerim sva rekonceptualizirali in posledično opustili »erotiko«. Refleksija in rekonceptualizacija je potekala ne le v razmerju do sodobnih kategorij, ki jih uporablja pornoindustrija, temveč tudi v odnosu do dominantnih feminističnih opredelitev v osemdesetih in devetdesetih letih. Tedaj je bil nujen pogoj za feministično definiranje pornomateriala eksplicitnost spolnega dejanja ali anatomije, »erotika« pa je pomenila z vidika spolov sprejemljive konstrukcije seksualnosti. Danes argumentirano trdimo, da je za delovanje pornografske norme dovolj kakršen koli žanrski vpis pornoseksualnega in tudi »erotika $\ll$ klinču pornoindustrije ne more biti izvzeta. ${ }^{8}$ Da bi opozorili na to dimenzijo navedenega podžanra, ga pojmovno opredeljujeva kot porno chic, če so materiali povezani s komercialnimi dejavni$\mathrm{ki}$ in tako vsaj posredno tudi s pornografsko industrijo. $\mathrm{V}$ tem smislu gre za vse oblike kupljive seksualnosti, tudi če se, denimo, s porno chic ponudbo želi povečati zaslužek operaterja ali ponudnika vsebin in upravljalca ali upravljalke spletne strani. Med vsebine porno chic tako prištevava tudi gra-

${ }^{8} \mathrm{Ob}$ tem gre lahko tudi le za nekaj gole kože, priprte oči in ustnice $\mathrm{v}$ »erotično « zanesenem smehljaju, skratka za mimiko in postavitev, ki sta žanrski. 
divo, ki ni mišljeno kot vir neposrednega zaslužka, a s preostalo vsebino informativnega medija ali drugega komunikacijskega sredstva nima nobene povezave (značilne fotografije na osrednji strani informativnih dnevnikov ali tedenskih publikacij, koledarji, »seksi« podobe ali zgodbe na mobilnih portalih in podobno).

Drugo gradivo, ki nosi pornografski pečat, a ne sodi pod opisane zvrsti, je zaradi načela transparentne taksonomije pojmovan kot pornografiziran in ne pornografski. Pristop je povsem v skladu $\mathrm{z}$ historičnim pojmovanjem pornografije; v antični Grčiji je »pornografija « pomenila opis dejavnosti prostitutk (Slapšak, 2001: 36).

Evidentno je, da pornogradivo in pornoperformanse (šovi peep in ostale komercialne »erotične « predstave in plesi) ter pornografizirane konstrukcije seksualnosti ločujemo od konstrukcij spolnosti, ki so umetniške, informativne, medicinske, poljudno publicistične, filozofske in kultno religiozne (na primer tantra) in podobno. Kadar se v navedenih zvrsteh dogaja pornografizacija, je kontekstualizirana, kar onemogoča nereflektirano pornografsko konzumpcijo in učinek. Ločitev pornografskega, pornografiziranega in seksualnega je v našem kontekstu neobremenjena s »spolno eksplicitnim «.

Tako zastavljeno koncipiranje pornografije je pomembna osnova za razumevanje konstrukcij seksualiziranega nasilja in spolnega nasilja. V najbolj prisotnih in zato najbolj potencialno spornih oblikah so te konstrukcije sprege spolnosti in nasilja prepletene s komercialnimi izdelki in plačljivimi storitvami novih medijev. Gre za pornoseks in nasilje, ki sta na voljo na spletnih straneh, mobilnih portalih, $v$ računalniških igrah/na igralnih konzolah, v oglaševanju spolnih storitev v tiskanih informativnih medijih, na televiziji, v neinformativnem tisku, plakatiranju in podobno.

Seksualizirano nasilje je že tradicionalno konstitutivni element filmov groze in nasilja, tj. filmov slasher (Itzin, 2001b: 450); v kibernetskem svetu, vključno z igrami, se pogosto kaže $\gg$ zgolj« v seksapilnih podobah in vedenju oboroženih bojevnic, heroin ali zapeljivih bojevnikov. Konstrukcije spolnega nasilja imajo najočitnejšo vlogo v vzporednih življenjih v virtualnih skupnostih (Second Life, My Space); posledično je virtualno posilstvo z empiričnimi, utelešenimi učinki v sociologiji in socialni psihologiji že priznano »družbeno dejstvo«. Kot seksualno nasilje razumemo tudi uprizarjanje zapeljevanja in spolnega nadlegovanja v okviru tradicionalne paradigme, kjer vloga »pravega « moškega zapeljivca korespondira z idejo o upravičeno nasilnih sredstvih (grobo prepričevanje, opijanje ali drogiranje žen- 
ske ipd.). Prav tako v tem okviru interpretiramo fenomen pornografizacije deklet skozi nepooblaščeno fotografiranje ali snemanje z mobilnim telefonom $\mathrm{v}$ določenih intimnih situacijah in distribucijo posnetkov po omrežju. Gre za pornografizacijo s popularno metodo »naredi sam/-a« (DIY, do-it-yourself), ki je ena od dominantnih dejavnikov novomedijske moči v reproduciranju spolnih vlog v diskriminatornem razmerju.

Medsebojna povezanost spolnosti in nasilja je v različnih diskurzih konceptualno raznoliko zaobjeta. Pornoindustrija v okviru pornografskih podžanrov umešča sadomazohizem $v$ register konsenzualne spolnosti; pri nas in drugje $\mathrm{v} E U$ so konstrukcije tovrstne pornoseksualnosti večinoma nelegalne. Problematika s/m porna z vidika obravnave pornografskega nasilja je bila tudi v okviru feministične teorije že tematizirana; prav tako so bile izpostavljene ambivalence $\mathrm{v}$ opredeljevanju sadomazohističnega porna kot konsenzualnega ali pa, nasprotno, nasilnega oziroma nekonsenzualnega uprizarjanja spolnosti (Šribar, 2006: 43-44). Čeprav to teoretsko dilemo puščava odprto, je z aplikativnega vidika - glede na funkcionalnost regulacijskih mehanizmov - smiselna umestitev $\mathrm{s} / \mathrm{m}$ pod pornografsko nasilne, spolno nekonsenzualne vsebine. Poseben problem skrajnih in nelegalnih konstrukcij spolnega nasilja so pornofilmi snuff z dejansko umorjenimi akterkami. Krog pornofilov in pornolobija obstoj teh filmov v svetu in pri nas zanika; v Sloveniji se je teme z negiranjem realnih umorov lotila tudi priznana filmska kritika (prim. Vrdlovec, 2007). Pomenljiv z vidika družbenega položaja spolov in konstrukcij seksualnosti je že sam obstoj tega podžanra ne glede na to, ali je v produkcijo vključen kriminal; gre za problematičnost konstituiranja užitka skozi destrukcijo ženskega telesa ne glede na to, če je ta imaginarna (Russell, 1993: 97-98). Ob tem naj poudarimo, da razdejanje, ki ga doživi žensko telo9 v pornu, predstavlja problem v prvi vrsti zato, ker ni kontekstualizirano, ker ni vzpostavljena kritična distanca, ki je sicer lahko bodisi filozofskega, umetniškega ali pa informativnega značaja.

Edina oblika konstrukcij spolnega nasilja v pornografiji, od katere se v veliki meri distancira tudi sama pornoindustrija, je otroška pornografija. $\mathrm{Na}$ tem področju so zastavljene široke mednarodne kampanje osveščanja, informiranja, preventive in detektiranja, ki se v okviru nacionalnih držav udejanjajo v obliki informativnih spletnih strani in prijavnih točk. (V Sloveniji je najodmevnejše internetno mesto za prijavo otroške pornografije in sovražnega govora Spletno oko.)

${ }^{9} \mathrm{~V}$ homoseksualnem pornografskem podžanru lahko uničevanje doživi moško telo na ženski poziciji. 
Sociološke in socialnopsihološke raziskave učinkov porna pogosto uporabljajo klasifikacijo $\mathrm{z}$ vidika vključenosti evidentnih oblik nasilja; gre za opredelitve »nasilna pornografija« oziroma »nekonsenzualna pornografija $\ll \mathrm{v}$ nasprotju $\mathrm{z} \gg$ nenasilno $\ll$, , $\gg$ konsenzualno pornografijo $\ll$ in/ali $\gg$ erotiko «. Ta pristop, značilen za osemdeseta in devetdeseta leta 20. stoletja, je vplival na legislativne ukrepe in jurisdikcije. Danes z vidika sodobnih socioloških in ekspertnih regulacijskih diskurzov ni več smiseln, saj je refleksija o spolnosti in nasilju privedla do subtilnejšega vpogleda, ki prepoznava nasilje tudi v navidezno konsenzualni spolnosti. Študija v okviru mednarodnega programa EU Kids on Line opozarja, da zaradi možnosti medsebojne povezanosti spolnosti in nasilja v kulturnih artefaktih včasih lahko zgolj shematsko delimo konstrukcije obeh področij človeškega življenja (Hasebrink et al., 2008: 8).

Strokovne, predvsem pravne in druge regulacijske definicije in poimenovanja porna in konstrukcij nasilja redko zaobjemajo obravnavano medsebojno povezanost med spolnostjo in nasiljem. Direktiva EU, ki se nanaša na avdiovizualni sektor, eksplicitno govori o pornografiji in »neupravičenemu « nasilju; drugačne konstrukcije nasilja in seksualnosti indeksira posredno. Pornografijo segmentira glede na učinek, na tisto, ki bi lahko »resno škodovala«, in drugo, ki bi »utegnila škodovati«. Kaj to pomeni v razmerju do pornografskih podžanrov in žanrov ter prizorov spolnosti in nasilja, je odvisno od vladajočih opredelitev v državah članicah.

(1) Države članice sprejemajo ustrezne ukrepe, s katerimi zagotovijo, da programi izdajateljev televizijskih programov pod njihovo sodno pristojnostjo ne vključujejo nobenih vsebin, ki bi resno škodovale fizičnemu, duševnemu ali moralnemu razvoju mladoletnikov, zlasti takšnih vsebin, ki vsebujejo pornografijo ali neupravičeno nasilje. (2) Ukrep, določen v odstavku 1, velja tudi za druge programske vsebine, ki bi utegnile škodovati fizičnemu, duševnemu ali moralnemu razvoju mladoletnikov, razen kadar se z izbranim časom razširjanja ali s tehničnimi sredstvi zagotovi, da mladoletniki na območju prenosa v normalnih razmerah ne bodo videli ali slišali takšnih vsebin (AVMS, 27 čl.).

Še vedno aktualni slovenski zakon o medijih (ta je v letu 2010 sicer v prenovi), ki se v nanašajočem členu naslavlja v prvi vrsti na televizijo, opredeljuje pornografijo na prvi pogled tako kot navedena direktiva (ZMed - 1 2006, 84 čl.). ${ }^{10}$ Zakon predpisuje tudi interne kodekse in njihovo strokov-

\footnotetext{
${ }^{10}$ Vendar je ta artikulacija sporna, še posebej očitno glede nasilja, saj je razumeti, kot da se tako potencialno »resno škodljivo « kot »škodljivo « opredeljevanje nanaša v obeh primerih na »pretirano « nasilje (84. čl, alineja 1 in 2):
} 
no podlago, artikulacijo neobvezujočih smernic, ki so naknadno dobile naziv $\gg$ Smernice za vsebinsko oblikovanje internih etičnih in estetskih pravil (kodeksov) izdajateljev televizijskih programov « (SRDF, 2006). Klasifikacija obravnavanih vsebin izhaja iz možnih učinkov, zakonskih določil o predvajanju in prepoznavnih vsebinskih elementov: »programske vsebine, ki se ne smejo predvajati (določeni pornografski podžanri ... pretirano nasilje in [žanri] z eksplicitnim nasiljem: pedofilski in nekrofilski materiali, pornografija s prizori sodomije, sado-mazohistična pornografija, vse druge oblike pornografije, ki vključujejo prikaze spolnih dejanj z uporabo takoj prepoznavnega in grobega nasilja) «; »vsebine, ki se lahko predvajajo pod določenimi pogoji ... Nasilne programske vsebine: oddaje in druga avdiovizualna dela, ki se predvajajo po televiziji ter prizori s fizičnim, verbalnim in drugim psihičnim nasiljem in (samo)destruktivnim vedenjem «.

Zaradi pomanjkanja drugih regulacijskih orodij so $v$ register konstrukcij nasilja vključene tudi druge potencialno škodljive vsebine: »strah, diskriminatoren jezik in nevarno obnašanje, zloraba alkohola in mehkih drog, raba težkih drog in okultnih praks in močno preklinjanje«. Kot nasilne so pojmovane tudi vsebine, ki prikazujejo nasilje tako, »kot da gre za spolnost (posilstvo, poskus posilstva, druge oblike fizično in psihično očitno nasilnega poseganja $\mathrm{v}$ intimnost druge osebe) «. Tudi pri obrazložitvi diskriminacijskih vsebin je na prvem mestu navedeno »raznovrstno poniževanje na osnovi spola«, kar prinaša dodatno orodje za indeksiranje konstrukcij medsebojne povezanosti spolnosti in nasilja na osnovi tradicionalnih spolnih vlog. In nadalje: pri segmentaciji nasilja je ponovno posebej navedeno »nasilje 'kot spolnost' (posilstvo in drugo očitno nasilje nad osebno in posebej spolno integriteto) «. Smernice opredeljujejo dovoljene »seksualne programske vsebine « $\mathrm{v}$ razliki od nedovoljenih in dovoljenih pornografskih: »seksualni prizori v pornografskih filmih [se] razlikujejo od seksualnih prizorov v drugih oddajah in avdiovizualnih delih «; to so »oddaje in druga avdiovizualna dela, predvajana po televiziji, ter prizori $s$ človeško seksualnostjo, prikazano na način, ki otrokom in mladoletnim v vsakdanjem življenju ni enostavno dostopen «.

Razlika je tako v kontekstu prizorov, značilnem za žanr, kot v sami postavitvi prizorov, vključujoči pojavnost akterk in akterjev, njihovo razmer-

(1) Televizijski programi ne smejo predvajati pornografije in pretiranega nasilja, če bi lahko predvajanje resno škodovalo duševnemu, moralnemu ali telesnemu razvoju otrok in mladoletnikov. (2) Predvajanje vsebin iz prejšnjega odstavka, ki utegne škodovati otrokom in mladoletnikom, je dopustno le pod pogojem, da je s tehničnimi sredstvi oziroma z zaščito omejeno tako, da otroci in mladoletniki do takšnih vsebin nimajo dostopa. 
je in sceno s pripadajočimi predmeti. Kot prizori pornografske seksualnosti se v skladu z izvornim pomenom termina pornografija obravnavajo tudi deli oglaševalskih, zabavnih, dokumentarnih in resničnostnih oddaj, ki vključujejo prikaze komercializirane seksualnosti (oglasi za vroče telefone, »dokumentarni« posnetki predstav v nočnih klubih in klasično prostituiranje); predvajanje teh vsebin se obravnava na enak način kot predvajanje pornografije, razen v primeru, kadar so pornografski prizori predstavljeni $\mathrm{v}$ ustrezni družbeno kritični luči.

Poleg žanrske opredelitve pornografije je ta tako kot konstrukcije nasilja segmentirana, pri čemer je bil tudi v normativni diskurz vpeljan koncept porno chic. Smernice v tem delu razgradijo vladajočo predstavo, da je $\gg$ mehka« pornografija nenasilna, sicer pa povzemajo izraza iz socioloških in socialno psiholoških raziskav: »nekonsenzualna « in »nasilna« pornografija. Definicija podžanra vključuje senzibiliziran odnos do manj očitnih oblik nasilja. V občo opredelitev legalnih oblik porna je vključen niz diskriminacij, ne zgolj spolna.

Pornografija: pornografski šik, porno romanca in druge dominantne pornografske žanrske oblike z značilnimi ponižujočimi prikazi pornografske spolnosti, ki vključujejo neenako razmerje moči z vidika spola, rasne, nacionalne in etnične pripadnosti, spolne usmerjenosti, družbenega sloja in delovnih, starostnih ali drugih razmerij; žanr opredeljuje tudi značilno obravnavanje telesnosti, ki neuravnoteženo po eni strani komodificira, po drugi pa glorificira anatomske značilnosti in na ta način vzpostavlja stereotipno in hierarhično razmerje med seksualnimi vlogami.

Pornografija, v kateri prevladuje nasilje, je strokovno poimenovana z izrazom nasilna pornografija; v primeru, ko porno vključuje prizore s splošno prepoznavnimi oblikami nasilja, se imenuje nekonsenzualna pornografija; slednja se lahko v klasičnih opredelitvah pornografskih pod-žanrov pojavi tudiv registru t. i. mehke pornografije (SRDF, 2006).

Naj tule dodava še pojasnilo, da obravnavano sprego spolnosti in nasilja smernice tematizirajo $\mathrm{v}$ referenčnem okviru regulacije, v sklopu konstrukcij nasilja, pornografije in seksualnosti. Klasifikacija nasilnih vsebin vključuje spolno nasilje (»nasilje kot spolnost «). Pri tem navajanje variacij v konstrukcijah spolnega nasilja vključuje tudi subtilne oblike. Te so podrobneje navedene v okviru seksualnih vsebin: »namerno zavajanje, manipulativno prepričevanje, alkoholiziranje druge osebe «. Med nasilne vsebine je med drugim vključena diskriminacija, na prvem mestu po spolu. Tudi 
to normativno orodje je primerno za prepoznavanje in ukrepanje $\mathrm{v}$ primeru spolno ponižujočih konstrukcij sprege spolnosti in nasilja. Ob tem naj navedemo, da je vzorčni klasifikacijski sistem EU Kijkwijzer, ${ }^{11}$ ki ga uporablja nizozemska koregulacijska ustanova NICAM, vpeljal posebno tematsko skupino »mizoginija« (Kijkwijzer, 2007). Uporablja se pri klasifikaciji filmov, DVD-jev, televizijskih programskih vsebin in glasbenih spotov.

Prepoznavanje imanentno nasilnih vsebin tudi v subtilnejših oblikah porna je v smernicah prepoznano skozi neenako razmerje moči, predvsem kot neopazno nasilje v »mehkem « podžanru. ${ }^{12}$ Povzeto gradivo smernic je prispevek $\mathrm{k}$ razumevanju konstrukcij sprege nasilja in seksualnosti ${ }^{13}$ same aplikacije v internih kodeksih izdajateljev programskih vsebin pa teh spoznavnih dimenzij ne vključujejo (Boldin, 2008: 50-51), vsaj ne v meri, ki bi pripomogla $\mathrm{k}$ javnemu prepoznavanju problematike.

Medijski diskurz v tematizaciji konstrukcij medsebojne povezanosti nasilja in seksualnosti je preverljiv ne le skozi semiotično analizo novinarskih prispevkov v informativnih medijih o tematiki, ${ }^{14}$ temveč tudi skozi koncepcije v kodeksih. Čeprav sklepava, da je prepoznavanje pomena in vloge sprege nasilja in spolnosti s strani medijev težavno, sva nadgradili predstavljen shematski okvir. V analizi problematike sva uvedli, kot je bilo že razvidno iz teksta, sintagmo seksualizirano nasilje. Ob tem misliva na vsebino računalniških iger, ki v nasilje vključujejo seksualni apel, in druge podobne kiberrealnosti; gre za transmisijo forme obravnavane sprege, saj se s tehnologijo zgolj čutno bolj atraktivno nadgrajuje tradicionalna seksualizacija žanrskega nasilja v filmskih trilerjih, kriminalkah in grozljivkah.

\section{Mladostniško ospoljenje v novomedijskih razmerjih}

Normativna orodja, ki sva jih predhodno predstavili, se nanašajo na zaščito otrok in mladoletnih. Na tem mestu se ne zdi najprimerneje tematizirati problematike zapostavljanja (novo)medijske pornodiskriminacije žensk v normativnih aktih in regulacijski praksi, vsekakor pa položaj in vloga

\footnotetext{
${ }^{11}$ Kijkwijzer je bil kot vzorčni model med drugim opredeljen na konferenci z naslovom »More trust in content«, ki je bila organizirana v času nemškega predsedovanja EU leta 2007.

${ }^{12}$ Danes bi bilo tu treba dodati porno chic.

${ }^{13}$ Čeprav smernice javno niso predstavljene kot avtorsko delo, naj v imenu korektnosti navedemo avtorstvo R. Šribar po naročilu agencije za pošto in elektronske komunikacije - APEK, september 2006.

${ }^{14} \mathrm{Na}$ tem mestu opozorimo na vztrajanje največje komercialne televizijske hiše z dvema kanaloma, Pop TV in Kanal A, pri opredelitvi »erotika« za vse vsebine seksualnega značaja ne glede na to, ali se poimenovanje nanaša na pornožanr ali ne. Enako ravnajo ponudniki vsebin na mobilnih portalih in oglaševalci storitev vročih linij.
} 
deklic korespondirata s položajem in vlogo žensk tudi v (novo)medijskih razmerjih. Pomembna topika obravnav so učinki (novo)medijskih vsebin (in storitev) na percepcijo stvarnosti s strani otrok in mladih in na njihova stališča ter vedenje, $s$ poudarkom na vztrajnosti, recikliranju tradicionalnih pomenov »femininosti $\ll$ in $\gg$ maskulinosti $\ll$. Poleg spola je izpostavljena perspektiva seksualnosti; povečini gre za iskanje odgovorov na vprašanje, kako vsebine novih medijev učinkujejo na (ne)sposobnost otrok in mladoletnih za razvijanje in vzdrževanje sodelujočih, nenasilnih medsebojnih odnosov in seksualnosti. Na podlagi raziskav se vzpostavljajo tudi spoznavna orodja za osveščanje, opolnomočenje in informiranje otrok in mladoletnih za kritično držo do potencialno škodljivih vsebin oziroma poznavanje in obrambo pred tveganji (zlasti spletnimi).

\section{»Maskulinost «, »femininost «}

Kulturološke in antropološke oziroma etnografske študije ugotavljajo in s tem na svoj način tudi prispevajo $\mathrm{k}$ njihovi stabilnosti - nove globalizirane trende, osrediščene okoli spolnih konstrukcij v družbeni skupini otrok in mladoletnih. Britanski avtorici A. Nayak in M. J. Kehily povzemata najpomembnejša dela na področju v zadnjih desetletjih in interpretirata »maskulinost « in »femininost « v razmerju odvisnosti od kulturnih artefaktov. V skladu z njunimi ugotovitvami in povzetki drugih del ni odmika od tradicionalnih vlog ali pa je ta parcialen; $\mathrm{v}$ sferi seksualnosti to pomeni, da spolna moč privilegira t. i. maskulinost, ta pa je v segmentu dečkov (kot sva že argumentirali na drugem mestu in s pomočjo druge reference) povezana z grobostjo (Nayak in Kehily, 2008: 10-11). Za našo tematizacijo je pomembna konstatacija, da je tudi razredni boj oziroma slojne neenakosti v odraščanju treba razumeti ne le v razmerjih dela, ampak tudi z vidika uzurpacije kulture, čustev, dispozicij (Skeggs, 2005: 63 v Nayak in Kehily, 2008: 49). V tem smislu je potemtakem še vedno upravičeno pojmovati popularno oziroma komercialno kulturo, edino nosilko obravnavanih konstrukcij spolnosti in nasilja, kot močan vir in dejavnik razslojevanja iz perspektive družbene moči že v najzgodnejši dobi. ${ }^{15}$ Spolna moč, ki se v segmentu ekonomsko prikrajšanih moških najbolj inducira skozi vladavino porna, (p)ostaja substitucija za aktivno državljansko držo; na ta način se nevtralizira možnost državljanske nepokorščine v vse bolj marginaliziranih slojih revnih mladih moških.

${ }^{15}$ Naj na tem mestu povzamemo izjavo dečka iz izobraženske srednjeslojne družine, da je »gledanje erotike« zanje neustrezno; ob tem je $\mathrm{z}$ »erotiko « mislil na dejansko seksapilno vedenje mladega dekleta. 
Komercialna seksualizacija

V dekliškem oziroma ženskem odraščanju je vloga pornografije, pornografizacije in drugih oblik seksualizacije, povezanih s trženjem, prav tako zaznamovana $z$ družbenimi razmerji moči. $V$ predhodno navedenem delu je komercialna seksualizacija tematizirana kot ambivalenten dejavnik, saj trend nove »dekliške moči< v skladu z avtoricama A. Nayak in M. J. Kehily sovpada s pornografizacijo in pornografijo oziroma ne vključuje (več) seksualizacije kot političnega projekta (ibid.: 60). Gre za pogoje nove »seksualne pogodbe « (McRobbie, v Nayak in Kehily, 2008: 68), zaradi katere dekleta svoje možnosti v družbi, vključno s politizacijo, »plačujejo $s$ privzemanjem zapovedi o spolno zapeljivem videzu. Odpira se vprašanje ustreznosti izraza »pogodba«, saj ta implicira, da naj bi bila seksualnost $\mathrm{v}$ pristojnosti samih deklic in deklet; samo na ta način bi jo namreč lahko umestile v družbene odnose kot relativno avtonomen dejavnik. Koncept seksualne pogodbe lahko spodbudi zanemarjanje temeljnega razmisleka feministične teorije in klasične antropologije o vlogi norm seksualnosti pri oblikovanju ospoljenega sebstva/subjektivnosti v družbenih strukturah; ženska seksualnost je razumljena kot ena temeljnih družbenih investicij v spolno hierarhični družbeni ureditvi. Ideja o dekletih, ki se ponujajo kot seksualno razpoložena/razpoložljiva v zameno za možnosti na področju izobraževanja in vstopa $\mathrm{v}$ javno sfero, je možna le ob nekritičnem pojmovanju tako fenomena seksualnosti kot tudi dejanskih možnosti deklet v izobraževalnem sistemu in na primer na vodilnih mestih na trgu dela ali v institucionalizirani politiki ipd. (več o zadevni kritični analizi v Antić, 2007: 113; Foucault, 1998: 5-6; Vendramin, 2009: 72, 77, 81, in nasl.).

\section{Razredna razmerja v segmentu deklet}

Konstrukcije dekliškega otroštva in mladosti glede na pornografizacijo in druge oblike tržno popredmetene spolnosti se običajno analizirajo glede na dve nosilni hipotezi. Prva izhaja iz postulata o dekletih, ki so prav $\gg$ neotroško « poslušna (o tem piše na primer tudi V. Walkerdine, 1998: 256); so tudi neposredno odzivna na vladajoče modele seksualizacije. Druga predpostavka, ki se tiče dekliške (samo)seksualizacije kot dejanja upora, izhaja iz prepričanja, da so v razmerjih spolnosti možne avtonomne drže, otočki seksualne svobode, ki prebijajo foucaultovski seksualni dispozitiv; gre za predstavo o nekakšnem postmodernem samoizumljanju (angl. self-invention) na področju spolnosti. ${ }^{16}$ Problem nastane, če teza o takšni refleksiv-

\footnotetext{
${ }^{16}$ Slednje je moč zaslediti predvsem v tu že interpretiranih pogovorih z zaposlenimi v pedagoškem poklicu, ki spolno nasilje razumejo $\mathrm{v}$ interakciji med dekleti in fanti, pri čemer naj bi dekleta
} 
ni seksualizaciji oziroma samoseksualizaciji ni speta z določenim pojmovanjem družbe in kulture. Novo refleksivno sebstvo sodobna feministična interpretacija družbe namreč pojmuje kot mehanizem, ki nadomesti razred, a z njim vendarle reproducira razredna razmerja (Skeggs, v Wood in Skeggs, 2008: 181).

$\mathrm{V}$ analizi fenomenov komercialne seksualizacije deklet iz perspektive ekonomskih razredov in pripadajočih kulturno-slojnih etnografij poleg B. Skeggs (Skeggs, v Nayak in Kehily, 2008: 49) družbeno senzibilnost na področju odraščanja izkazuje tudi, denimo, teoretsko široko priznana $\mathrm{V}$. Walkerdine. Njene družbeno kritične študije seksualizacije odraščajočih med drugim argumentirajo, da je medsebojna povezanost med ofenzivno medijsko in informacijsko-komunikacijsko seksualizacijo deklet in strokovnimi ali poljudnimi interpretacijami, ki govorijo o njihovi submisivnosti in družbenem predpisovanju ženskih vlog v seksualnosti, moralističnega značaja. Moralistično izhodišče pa je značilno za relativno ekonomsko zavarovan svet srednjega razreda, ki zmore varovati svoje otroke pred realnostjo financ. Vdor »erotizacije«s popularno kulturo, ki pomeni nižanje moralnih standardov srednjega razreda (in navidezno nasprotujoča si predstava o vsiljevanju spolnosti odraslih otrokom in ogrožajoči Loliti), dobi svoj kontrapunkt v nižjih slojih; zanje fantazme, ki segajo od otroške Lolite do erotično prisrčnega dekletca, ki lahko omreži pripadnika višjega sloja, pomeni možnost spremembe družbenega statusa (1998: 257-258, 163).

V obeh primerih je objekt želje izza seksualiziranih deklic srednjeslojni prestiž, ne glede na to, ali ga je treba obdržati ali pridobiti. Na ta način navedena avtorica (sicer posredno) »demistificira« proletarski naboj, ki naj bi ga s seboj nosila pornografizacija družbe. Glede na že omenjeno tezo o razredih z vidika kulturnih dobrin je statusni preskok možno razumeti tudi v razmerjih osebne prepoznavnosti v javnosti in z njo povezanih socialnih virov. Pornografizacija in druge oblike komercialne (samo)seksualizacije so v dekliških in/ali starševskih očeh tako osmišljene kot »povzpetniška《 strategija na poti do »slave «.

Kot izhodišče za preciznejšo študijo družbenih in kulturnih pogojev (samo)pornografizacije naj predstavimo biografski drobec, ki je deloma fiktiven, deloma pa sestavljen iz več dejanskih pripovedi in opažanj. ${ }^{17}$ Gre

\footnotetext{
»izzivala« (Šribar, 2009). Diskurz, ki krivi žrtev (dvakratno žrtvovanje v spolnem nasilju, prvič $\mathrm{v}$ samem aktu in drugič v njegovi interpretaciji), se je v razmerjih komercializirane seksualnosti in dekliškega privzemanja vladajočih seksualnih vlog rekonstruiral in s tem dobil nov zagon. ${ }^{17}$ Ta način sva izbrali zaradi spoštovanja etičnih načel raziskovanja, zlasti načela o varovanju osebnih podatkov in človeški integriteti. »Sestavljena zgodba« je način, kako se je prepoznavnos-
} 
za nekaj let staro deklico, katere starši pripadajo nižjemu sloju. Slab ekonomski položaj družine je lahko prepoznaven, saj živijo v izjemno revnem življenjskem okolju. Oba, oče in mati namenjata deklici veliko pozornosti. Močno spodbujata njene talente in ji dajeta občutek, da bo ona tista, ki bo v življenju nekaj dosegla. Kljub zgodnjim otroškim letom se deklica že zaveda, da ima od vseh članov in članic družine v prihodnosti največ možnosti. To je razvidno iz otroško ošabnega obnašanja. Osrednjo pozornost namenjajo deklici tudi stari starši, ki živijo v neposredni bližini. Vsi odrasli uživajo ob razvoju edinke pri petju in sposobnosti poziranja. Spremljajo razpise in deklico prijavljajo na različna tekmovanja, $s$ kar nekaj truda so jo spravili tudi že na naslovnico kataloga za prodajo po pošti. Starši so bili veseli honorarja, predvsem oče projicira uspeh družine, tudi finančni, v deklico. Zato so tudi finančni vložki v hčerko v relativnem smislu veliki; fotografije deklice, ki v narejenih pozah povzema tip Lolite, se kopičijo in starši so zelo ponosni nanje.

\section{Študija primera: (samo)pornografizacija}

Tudi mera ženske/dekliške spolne privlačnosti se vzpostavlja preko pornografskih in pornografiziranih podob $\mathrm{v}$ medijih (vključno $\mathrm{z}$ izdelki in storitvami informacijsko-komunikacijske tehnologije oziroma novimi mediji) in $\mathrm{v}$ širši sferi javnega komuniciranja in popularne kulturne produkcije (oglaševanje, modna in glasbena industrija). (Samo)pornografizacija deklic kot modus sodobne seksualizacije, ki se kaže kot moda in vêdenje, je v znanosti vrednotno ambivalenten pojem, saj poleg ponotranjenja represivnih kulturnih norm vključuje moment samorefleksivnosti in tako nosi pomen možnosti ukinjanja tradicije dekliškega romantičnega eroticizma. V nadaljevanju preverjava to, zadnjo interpretacijo.

$\mathrm{Za}$ (samo)pornografizacijo v družbenih pogojih neoliberalizma je značilno, da je učinek kapitalskih trendov, ti so tudi mejniki možne avtonomije in samorefleksivnosti vladajoče dekliške seksualizacije. Zato tudi ni smotrno govoriti o liberalizaciji seksualnosti v razmerjih (samo)pornografizacije. Drug vidik pornografske (samo)seksualizacije deklic, ki prav tako ne govori v prid novi dekliški avtonomiji in refleksivnosti na področju seksualnosti, je recikliranje diskriminatornih tradicionalnih spolnih vlog v spolnosti, spričo katerih je dekliška seksualna odprtost in »aktivnost « bolj stvar forme kot temeljnih sprememb na področju čustvovanja in spolne drže. Ali, če povemo z besedami ene od respondentk v skandina-

ti oseb in morebitnim drugim škodljivim učinkom izognila kolegica M. Dobnikar v času dela z žrtvami spolnega nasilja (osebni pogovor, junij 2010). 
vskem raziskovanju, v notranjosti so še vedno dekliško drgetave, hrepeneče (angl. fluffy) (Nielsen, 2004: 19). Pornografija, ali bolje, (samo)pornografizacija kot »javnost seksa « (izvorno on/scenity) (Williams, 2004: 3) vsaj navidezno prinaša nove kode seksualnega vedenja, gotovo pa ne globljih sprememb v hierarhičnih spolnih razmerjih na področju seksualnosti, v okviru katere dekleta vendarle niso avtonomne v svoji spolni želji v smislu celovitega uravnavanja seksualnosti skupaj z emocijami, ki so povezane z intimnimi odnosi. Dilema med »hrepenenjem« in možnostjo seksualnega eksperimentiranja, kot ga kodira pornografizacija kulture, se potemtakem ne odraža le v načinu seksualizacije, temveč tudi v notranjih dekliških ambivalencah.

Pornografska (samo)seksualizacija kljub morda aktivnejšemu ali vsaj zavestnejšemu odnosu deklet do spolnosti tudi ne spreminja temeljne seksualne ekonomije, ki jo je še utrdila ortodoksna psihoanalitska interpretacija. V feminističnem prevzemanju in uporabi tez psihoanalize se spolna razmerja v seksualnosti obravnavajo glede na spolno moč. Pornografija tudi v tem refleksivnem kontekstu utrjuje žensko pasivno pozicijo, $z$ vidika vladajočega vrednotenja manjvredni položaj »penetrirane « (ne glede na pornografsko aktivno izražanje spolne pobude žensk). Ta »pornopenetracija « se dogaja prav tako na ravni pogleda (Brown, 1981: 14; Keppeler, 2001: 93). Ženska je tista, ${ }^{18} \mathrm{ki}$ jo v uprizarjanjih pornografizirane spolne želje razumemo kot vabo pogleda - in to navkljub lahko razberljivi pornografski glorifikaciji moške erekcije na imaginarni ravni.

Pornografija in spolne vloge v pornografski seksualnosti v luči boja za pomen zastavljajo vprašanje o možnostih preobračanja pomenov in prepomenjanja spolnih vlog. Pozicijo »biti gledana « bi se lahko v tem smislu razumelo kot »imeti« pogled druge/-ga v lasti, »biti spolno razpoložljiva« pa »imeti« seksualnost, biti na enakovrednem položaju oblasti v domeni seksa. Vendar pa je taka možnost interpretacije zožena na družbeni aktivizem brez stabilne teoretske osnove, na hotenje po takem razumevanju pornografskih spolnih razmerij. Potlačeno je namreč vsaj dvoje družbenih dejstev: ženski boj za pogled - ta je sestavni del socializacije žensk v patriarhalno kulturo medsebojne tekmovalnosti - in odvisnost od nosilca pogleda, kar pomeni manko avtonomije, videnje sebe skozi oči drugega. Pozicija posedovanja spolnosti, gospodarjenja spolni želji skozi pritegnitev in erotizacijo pogleda drugega je potemtakem hkrati še drugače negotova, saj so pogoji spolne želje netransparentni ne le za osebo, ki želi želečega drugega/-go, temveč tudi za slednjega/-njo.

${ }^{18}$ Ali moški na ženski poziciji v homoseksualni pornografiji. 
(Samo)pornografizacija deklet, ki se odvija zlasti na medmrežju, je v razmerjih spolov in spolne želje značilen pojav, sindrom partiarhalne organizacije spolnosti, saj akterke pornofotografij in gibljivih posnetkov primarno ostajajo na poziciji »kazati se«. Težava z ustvarjanjem novih pomenov je težko premagljiva brez novih pozicioniranj, brez pretočnosti spolov med položaji, kot jih pretežno in kulturno pogojeno razumemo: pasivnost (biti na ogled) in aktivnost (gledati). Samo z manj skrepenelimi aktivnimi in pasivnimi spolnimi pozicijami v seksualnosti je možno mehčati pojmovanja o hierarhičnih zasedbah vlog in tradicionalnih razmerjih moči. To je tudi teza, ki jo zagovarja teorija queer v okviru ukvarjanja s pluralizacijo seksualnih identitet (Beasley, 2005: 126). V nasprotnem primeru ostajamo $\mathrm{v}$ primežu konstrukcij seksualnosti, ki ne pomenijo drugega kot preigravanje istega v kulturi, ki pa nikakor nima značilnosti parodije (Jameson, 2001: 24-25), s tem pa ne družbeno kritičnega in prenovitvenega naboja.

Pričujočo tezo o manku moči prepomenjanja in rekonceptualizacije spolnih vlog na področju spolnosti skozi (samo)pornografizacijo deklet je možno argumentirati tudi $\mathrm{z}$ vpogledom $\mathrm{v}$ produkcijska in distribucijska razmerja. Za (samo)pornografiziranjem so najpogosteje spletne domene in agencije, ki spodbujajo in razširjajo obravnavane vizualne materiale. Tudi ikonografija redko presega utečeni pornografizirani seksualni imaginarij, vključno z lezbičnimi scenami, dodobra umeščenimi v dominantno heteroseksualno matrico. ${ }^{19}$ Raziskava, kam preko klikanja vodijo pornografske strani, je pokazala, da gre za zaslužek mainstream pornoindustrije (Playboy, Hustler in Private Media Group) (Johnson in Whitty, 2008) - predvsem na račun s pornostranmi povezanih oglaševalcev, ki na ta način pridejo do adrem za promocijo izdelkov seksualne narave (predvsem viagre). Končna ekonomska korist prevladujoče komercialno seksualne, predvsem pornografske industrije je tudi v ozadju ustvarjanja pomenov pornografskih in pornografiziranih podob; morajo se podrediti vladajočemu razumevanju pornospolnosti in ustreznih spolnih vlog. Dokazana komercialna zainteresiranost utemeljuje tudi najino poimenovanje fenomena s (samo) pornografizacijo, v nasprotnem primeru, tj. v popolnoma samoiniciativnem uprizarjanju spolnosti brez ekonomskega interesa, bi bila raba izraza neustrezna.

Izjemo v produkcijskem in distribucijskem načinu ter ikonografiji predstavljajo osebne strani - amaterska domača »pornografija « -, kar je pripeljalo do ugotavljanja možnosti »ženskega« soustvarjanja seksualnosti (na

\footnotetext{
${ }^{19} \mathrm{~V}$ temeljitejšo obravnavo sva vzeli stran Geek girls porn, dostop do nje pa je bil zaradi prijave otroške pornografije nedavno ukinjen.
} 
primer Attwood, 2007). A neizrečene predpostavke takih ugotovitev vendarle zaslužijo nekaj pozornosti, predvsem glede pogojev možnosti rekonstrukcij seksualnosti in konceptualnega preizpraševanja skupinskega ženskega subjekta. Slednji je predmet mnogih feminističnih teoretskih raziskav in je skoznje priznan večinoma kot parcialni, družbeno zainteresirani subjekt, ki je sporadičen in časovno zamejen. Skratka, nobenega univerzalnega ženskega subjekta ni, ki bi bil potencialni akter sprememb v konstrukcijah seksualnosti in $s$ tem v spolnih razmerjih moči. $S$ tem pa se ukinja tudi predstava o enovitem ženskem pojmovanju seksualnosti in takih konstrukcijah seksa, ki bi bile enotno kodirane kot prispevek k pravičnejšim razmerjem moči spolov na tem področju.

Še resnejši dvom o možnosti rekonstrukcije seksualnosti brez sprememb spolnega reda poraja teorija, kot jo razvija prominentna teoretičarka feminizmov in gibanja queer J. Butler. Avtorica razume (ospoljeno) sebstvo in seksualnost kot umeščeni in animirani od drugod. Jaz, ki naj bi spolnost »imel«, je razgrajen tudi skozi »svojo « lastno seksualnost. Vsaka avtentična seksualnost je fiktivna (Butler, 2004: 16). Na čutnonazorni ravni to pomeni, da se seksualnost lahko konstruira (tudi kot posamičen akt) zgolj v okviru obstoječih, rečeno s Foucaultom, dispozitivov, diskurzivnih in institucionalnih možnosti na polju seksualnosti (1986: 198). Novi diskurzi, institucije in prakse (in skupaj z njimi preseganje nove »brkljarije « starega) se vzpostavljajo s temeljnimi spremembami v družbi (prim. Močnik, 1999: 117-134, 162, 164-166). Brez subverzije patriarhalnega reda in prenove strukturnih elementov spolne ureditve na obravnavanem področju ni mogoče uvajati novosti in interpretirati določenih kulturnih fenomenov kot nekaj, kar presega obstoječe stanje. Iz te perspektive je hkrati tudi razumljivo, da je neproblematiziran ženski subjekt simptom šibkosti v razmerju do demokratizacije konstrukcij tako spola kot seksualnosti.

Teze o dekliški moči, ki se kaže tudi na področju spolnosti, je potemtakem konsistentno omejiti. V naši interpretaciji gre za fenomene, ki kažejo bodisi na novo brkljarijo elementov tradicionalnih konstrukcij seksualnosti ali na izjemne poskuse subverzije, ki bi s popularizacijo utegnili načeti sam spolni red. Dokler ostajajo ti alternativni načini spolnega življenja, četudi vznikajo v obče pripoznanih družbenih skupinah, stvar seksualne margine ali nevidnih intimnih praks posameznic/-kov, v obstoječih okvirih nimajo dovolj tiste družbene sile, ki bi sama po sebi že pomenila spremembo. Na to, kako izolirani so pojavi alternativnega dekliškega vedenja, povezanega s spolnostjo, kažejo, denimo, rezultati raziskav o spletnih tveganjih z vidika spola. Delitev vlog je povsem v redu konvencionalnih za- 
sedb: dekleta so pretežno prejemnice žalitev, pornografskega materiala in seksualnih pripomb, fantje pa aktivno iščejo pornografske in nasilne materiale (Hasebrink et al., 2008: 35).

Kljub tule že dovolj tematsko široki razpravi o (samo)pornografizaciji želiva osvetliti še dodaten problem, ki pa sega na področje polnoletnosti in je v tem smislu že zunaj najinega delovnega obsega. Zanima naju, kako s socialnopsihološkega vidika razložiti dejanski vstop deklet in mladih žensk na področje plačljive seksualnosti v pornografski industriji in z njo povezanim oglaševanjem ter produkcijo t. i. erotike (porno chic materiala oziroma posnetkov in snemanj pin-up). Odgovor na navedeni problem, ki vsaj deloma presega enostaven, neposreden argument pornografizirane kulture in družbenoslojnih pogojev, najdemo v okviru navedene discipline še najbolj neposredno v konceptu družbene vloge. Z njegovo pomočjo je možno nasprotovati tudi propornografskemu argumentu, da ženske prostovoljno vstopajo v tovrstno industrijo.

Francoski socialni psiholog J. L. Beauvois je v delu o liberalnem suženjstvu, izvorno izdanem leta 1994, opredelil iskanje vzrokov za »usodo « posameznika in posameznice na individualni ravni za temeljno sodobno spoznavno zmoto. Opozoril je na družbeno koristnost razlag o individualni odgovornosti in v nadaljevanju na prisilno notranjo moč vloge. Slednja je povezana z občutkom, ki nam pove, ali smo ali nismo na ravni zahteve po družbeni koristnosti (Beauvois, 2000: 41, 57 in 77). Kar je torej le individualnega pri odločitvi, denimo, za »kariero«pin-up dekleta, starlete Playboya ali akterke pornografiziranih fotografij v na primer Slovenskih novicah (če ostajamo znotraj državnih meja). Glede na to, da tako pojavljanje ne zanima vseh mladih žensk enako, sploh pa ga ne udejanijo ali poskušajo udejaniti kar vse, moramo izpostaviti diferencirane življenjske in karierne dejavnike - v okviru, na katerega kaže avtor: gre za pomen družbene strukture in mesto v njej, na katerem se znajdemo kot posameznice in posamezniki. Njegova trditev, da je konstrukt osebne odgovornosti koristen za družbo, namreč pomeni, da ta služi reproduciranju obstoječega družbenoekonomskega reda in zamegljevanju krivičnih, nedemokratičnih hierarhičnih razmerij.

Sam koncept vloge vključuje tudi individualne pogoje možnosti. Tudi ti kažejo na lokacijo v družbeni strukturi in z njo pogosto na mesto v diskurzivni mreži. Individualni pogoji zaobjemajo specifični splet družbeno-kulturnih dejavnikov (na primer ekonomsko stanje družine, izobrazba staršev, demografsko okolje, dojemanje telesnih značilnosti v širši kulturi, odnos do pornografizirane spolnosti pomembnih drugih in $\mathrm{v}$ širši javnosti 
itd.). Nič ni torej povsem osebnega, gre pa, razumljivo, za individualizirane nabore in načine prepletanja virov, s katerimi se odpirajo (omejene) možnosti za oblikovanje določene vloge, $\mathrm{v}$ našem primeru vloge (samo)pornografizirane starlete.

$S$ povedanim v nasprotju je, kot že izrečeno, vsakdanja »teorija « načina spoznavanja drugih in sebe, ki temelji na »'personalizaciji‘ socialnega sveta (Ule, 2009: 100), tj. na osebni odgovornosti in iniciaciji ter obvladovanju dejanj; v okviru socialne psihologije jo je v sedemdesetih letih preteklega stoletja prva razložila tradicionalna teorija pripisovanja. Tako v okviru te klasične teorije atribucije kot po Beauvoisovi razlagi pomena vloge in notranje prisile le-te velja, da so sebstvo in drugi/-ge razumljeni osebnostno in vzročno glede na cilje, namere, želje (ibid.) ali osebne, značajske lastnosti, ki pa se kategorizirajo prav na podlagi obstoječih ravnanj (Beauvois, 2000: 79). Sklepanje posameznice in posameznika o osebnih vzrokih za delovanje oziroma »usodo« druge/-ga (»internalne razlage«) je, kot piše avtor, po meri zlasti ekonomskega liberalizma; je maloumno, kar se tiče spoznavnega procesa (ibid.: 83). Sodobna teorija pripisovanja je sicer razširila pogled tudi na vsakdanje sklepanje ljudi o situacijskih (zunanjih) vzrokih za delovanje. Ti se laično vidijo v omejenosti situacij (prim. ibid.) in zunaj poglobljenih razumevanj odnosov. A so v svoji kompleksnosti tako v spontani misli kot tudi v znanstveni refleksiji težko dostopni. »Določila« delovanja so v nasprotju z racionalizacijami (Beauvois, 2000: 33), tj. vsakdanjimi pripovedmi o »vzrokih«, navsezadnje tudi stvar želje, nezavednega. Družbeno-kulturni dejavniki so na osebni ravni zakriti z nezavedno naravo želje oziroma se specifični, individualni splet družbeno-kulturnih pogojev možnosti za individualno vlogo/usodo prevaja tudi v specifičnost nezavedne želje, ${ }^{20} \mathrm{ki}$ pa je netransparentna že za njeno nosilko ali nosilca. Kar je dostopno, je omejen nabor družbenih in kulturnih dejavnikov, ki na specifične, netransparentne ali zgolj parcialno dostopne načine vplivajo na željo in delovanje. Ta težak, pravzaprav nemogoč kompleksen dostop do določil individualnega delovanja in »usode« je značilen tako za vsakodnevne zgodbe o vzrokih za lastno delovanje in vêdenje drugih kot za znanstveni diskurz.

Če tule izstopimo iz okvirov socialne psihologije in se vrnemo na široko področje kritičnih teorij družbe, postane umljivo, denimo, čemu Slavoj Žižek oporeka teži analize posameznih primerov nasilja (»subjektivno nasilje«) in ga kot fenomen razlaga v njegovih družbenostrukturnih razsežno-

${ }^{20}$ Željo razumemo v feministično teoretski interpretaciji psihoanalize: v njeni umeščenosti v nezavedno, a hkrati tudi v njeni spetosti z družbenimi dejavniki in spremenljivosti zaradi prehodnih, začasnih fantazem kulture. 
stih (Žižek, 2007: 16-18). Enako velja za interpretacije drugih pomembnih fenomenov, na primer, če ostanemo v naših tematskih okvirih, tudi konstrukcij nasilja, nasilne/pornografske spolnosti in nenasilnih oblik seksualnosti. ${ }^{21}$ Bolj kot analize konkretnih vplivov na vsakdanjost, korelacij in kovarianc so iz naše perspektive osmišljene interpretacije $\mathrm{v}$ okviru spolno in drugače hierarhičnih družbenih struktur. Tudi (samo)pornografizacijo deklet razbiramo z vidika njihovih možnih (izobrazba, ekonomske razmere, državljanski status ipd.) in danih položajev (ženski spol, mladostnice) v družbeni strukturi.

\section{Sociološki in socialnopsihološki pristop $\mathrm{k}$ potencialno škodljivim (novo)medijskim vsebinam in odnosom}

Raziskovanje učinkov medijev in novih medijev na otroke in odraščajoče je tu namenjeno zlasti povezanosti med konstrukcijami nasilja in spolnosti v medijih in percepcijo, stališči ter vêdenjem (Zillmann in Bryant, 1989; Gunter, 2002). V zadnjem desetletju je v tej znanstvenoraziskovalni disciplini kultura novih medijev (izdelkov in storitev IKT, posebej spletnih) in njenih učinkov na otroke in mlade pogosto tematizirana, vključno s kriminaliteto odraslih nad otroki in mladoletnimi ter medvrstniškim nasiljem (na primer Wall, 2007).

Statistične, laboratorijske in kabinetne raziskave generalno strukturirajo segment otrok in mladoletnih na različne načine, predvsem glede na starost in način vpletenosti v novomedijska razmerja. Ob tem je opazen povratek od raziskovalne tematizacije družbene škode k pogojem možnosti konkretne, individualizirane škode. To velja posebej za komercialne konstrukcije spolnosti s poudarkom na pornografiji; navedeno dejstvo s historičnega vidika implicira družbeno regresivno dogajanje, saj se je znanstvena in strokovna obravnava pornografije, na primer, utemeljila skozi socialnopsihološke vedenjske raziskave in koncept individualne škode, a je z nadaljnjo refleksijo stopilo v veljavo teoretsko razumevanje in pojmovanje strukturnih razmerij v družbi in pornografskih reproduciranj diskriminacij, zlasti spolne. Referenčna literatura celo beleži opisan prehod, premestitev v tematizaciji kot dogodek; ta se je zgodil v okviru kanadske jurisdikcije s primerom R. vs Butler (1985), v katerem je sodnik M. Shannon na podlagi sociološke klasifikacije spornega gradiva raziskovalca J. Checka izja-

\footnotetext{
${ }^{21}$ Tudi konstrukcije medsebojne povezanosti med spolnostjo in nasiljem, kamor prištevamo pornografijo, in konstrukcije nasilja pravzaprav sodijo v sam register nasilja, četudi je to izvorno »zgolj« diskurzivno in se udejanja skozi občutke moči na eni in nemoči, podrejenosti na drugi strani (pogleda).
} 
vil, da javno izpostavljanje pornografije povzroča družbeno škodo (Check, 2001: 351). Obenem s sodobno opustitvijo ali zanemarjanjem obravnave možnih performativnih učinkov podob komercialne spolnosti v procesu socializacije in $s$ povratkom $\mathrm{k}$ raziskovanju možnosti za individualno škodo (zlasti skozi kvantitativne, $\mathrm{v}$ velikih statističnih bazah utemeljene raziskave) se je zamenjala tudi perspektiva. Interpretacija žensk v diskriminatornih razmerjih pornografije je minimizirana, objekt družbene obravnave na vseh ravneh postajajo otroci (in mladoletne osebe). Družbeno-kulturnih vzrokov za opisano premeno je več, najbolj pa se omejenost novega pojmovanja kaže v pravnih orodjih, ki v tem registru (upravičeno) ščitijo otroke, a na račun žensk.

Množično prisotne potencialno škodljive vsebine, tj. pornografske in druge oblike komercialnih konstrukcij seksualnosti in nasilja, so glede na rezultate raziskave, ki je bila narejena v okviru Eurobarometra iz starševske perspektive v oktobru leta 2008, prvi problem »spletnih tveganj «. ${ }^{22}$ Vendar se diskusija o potencialni škodi v tem registru oži. V središču pozornosti so nelegalne konstrukcije, saj njihove legalne oblike prinašajo ogromno dobička - in dejstvo, da so tudi te potencialno škodljive (a na široki družbeni ravni), je vse bolj zanemarjeno. ${ }^{23}$ Po drugi strani pa se teme širijo. Tako na primer študija EU Kids on Line v izhodišču navaja tudi druga tveganja: aktivnosti $\gg$ pedofilov $\ll,{ }^{24}$ spletno navezovanje stikov (grooming) in virtualni stiki s tujci, ekstremno ali spolno nasilje, drugi škodljivi ali žaljivi materiali, rasistični/sovražni materiali in delovanje, oglaševalske in druge komercialne prisile, pristransko in napačno informiranje (razni nasveti, informacije s področja zdravja), zloraba osebnih podatkov, kibernetsko ustrahovanje, zalezovanje in nadlegovanje (angl. cyber-bullying, stalking, harassment), hazardiranje, finančne sheme, samopoškodovanje (samomor, anoreksija itn.), vdor v zasebnost in zloraba zasebnosti, druge nelegalne dejavnosti (hekerstvo, nelegalno nalaganje spletnih vsebin) (Hasebrink et al., 2008: 6). Vir gradiva s področja nasilja in spolnosti artikulira kot $\gg$ problematične seksualne vsebine « in objavljanje porna, »nasilne vsebine « in »nedolžno « zmerjanje (angl. happy slapping) (ibid.: 9).

\footnotetext{
22 Po mnenju staršev iz EU je največje tveganje interneta, da lahko otroci vidijo »eksplicitne spolne ali nasilne podobe «. Tako meni 65 odstotkov staršev in 45 odstotkov jih je zaradi tega zelo zaskrbljenih (Eurobarometer, 2008: 5).

${ }^{23}$ Temeljiteje medsebojno povezanost med politikami, kapitalom in raziskavami avtorici obdelujeva v članku z naslovom Spol v raziskovanju: od binarizma in homogenosti h kompleksnosti (Vendramin in Šribar, 2010).

${ }^{24} \mathrm{~V}$ imenu preciznosti bi bilo treba dodati še aktivnosti spolnih nasilnežev nad otroki, saj pedofilija kot bolezensko nagnjenje, ki se udejanja v spolnem nadlegovanju in zlorabljanju otrok, predstavlja zgolj del kriminalnih spolnih dejanj nad otroki (Sloyan, 2003).
} 
Razsežnosti potencialno škodljivih vsebin in tveganj v situacijah, povezanih z izdelki in storitvami IKT oziroma novimi mediji, se obravnavajo v različnih okvirih, pretežno naddržavnih. Tako so tudi raziskave, narejene v Sloveniji, opravljene praviloma v sklopu raziskovalnih programov in projektov EU. Pričujoče dejstvo ima tako svojo dobro kot slabo stran. Metodološko so te raziskave lahko sporne, kljub temu pa imajo rezultati strateško vrednost; delujejo $\mathrm{v}$ prid argumentaciji za izboljšanje politik $\mathrm{v}$ znanosti in na drugih področjih obravnave, predvsem $v$ sferi regulacije potencialno škodljivih vsebin in novomedijskih odnosov. Tako na primer že navedena raziskava Eurobarometra z naslovom Towards a Safer Use of the Internet for Children in the EU - a Parents' Perspective kaže na nadpovprečno izpostavljenost slovenskih otrok potencialno škodljivim vsebinam interneta in mobilne telefonije ter drugim tveganjem, kar bi moralo pomeniti motiv za vlaganje $\mathrm{v}$ raziskave in oblikovanje učinkovitih mehanizmov informiranja za starše in otroke ter instanc reguliranja. V skladu z rezultati si starši pri vzgoji in informiranju svojih otrok glede tveganih razmerij IKT v povprečju želijo kvalitetnejši pouk na področju interneta, več kampanj osveščanja v zvezi s spletnimi tveganji, boljše informacije in nasvete za starše na spletnih straneh, ki jih obiskujejo otroci, strožjo regulacijo za industrijo, ki izdaja spletne vsebine in opravlja spletne storitve, kontaktne točke za individualne nasvete staršem in otrokom o varni rabi interneta, boljši dostop in delovanje nadzornega softvera, organizacijo usposabljanja staršev s strani nevladnih organizacij, vlade in lokalnih oblasti. Odstotek slovenskih staršev, ki so prepričani, da bi vsaj en sklop od navedenih aktivnosti in ukrepov močno pripomogel k uresničevanju njihove odgovornosti, je precej višji od povprečja EU (SI: 56 \%, EU: 48 \%). Hkrati pa je delež slovenskih staršev, ki poznajo prijavno točko za sporne vsebine, najnižji v EU (Eurobarometer, 2008: 54, 59).

Obravnavane pregledne sociološke in socialnopsihološke raziskave z velikimi zajemi statističnih podatkov običajno poleg državljanskih, spolnih in starostnih kategorij otrok in mladih vključujejo tudi nekaj drugih variabel, na primer starševske računalniške kompetence. Kategorije so samoumevne, tj. neproblematizirane, tudi sam pojem otroka v funkciji raziskovalne kategorije najpogosteje implicira normo, nepolnoletno osebo v starosti do 18 let, čeprav je zgornja starostna meja, s katero v nekaterih normativnih dokumentih, ki se nanašajo na (novo)medijska razmerja, zamejimo otroštvo, pogosto nižja; po drugi strani pa se otroštvo podaljšuje onkraj polnoletnosti, aktivnost v odnosu do novih medijev pa se začenja zelo zgodaj, precej pred šolo. Toda izbor starostnih kategorij najpogosteje ni ar- 
gumentiran. Starostno strukturiranje v raziskavi Eurobarometra, denimo, vključuje starosti v razponu od 6 do 17 let (2008: 12). Tudi študija EU Kids on Line z naslovom Comparing Children's Online Opportunities and Risks Across Europe (Hasebrink et al., 2008) vključuje enako segmentacijo v starostne skupine (študija/poročilo se sklicuje na raziskavo Eurobarometra iz 1. 2005). Navedena študija obravnava spletna tveganja s poudarkom na vidiku vloge, bodisi pasivne ali aktivne; pristop pomeni preseganje prevladujočega pozicioniranja otroka in mladoletne osebe kot potencialne žrtve $\mathrm{v}$ raziskovalni tematiki. Aktivna in pasivna pozicija sta strukturirani glede na izdelek ali storitev IKT: v razmerju do vsebine je otrok prejemnik/ca javne komunikacije, glede na možnosti stika je lahko udeleženec/ka vrstniške ali druge osebne komunikacije, glede na možnosti vedenja lahko zavzame aktivno pozicijo z ustvarjanjem vsebin in osebnimi kontakti (ibid.: 8). ${ }^{25}$

${ }^{25}$ Končno poročilo je izšlo v avtorstvu Livingstone in Haddon (2009). 


\section{Potencialna škoda in}

onkraj nje v (novo)-

medijskih razmerjih

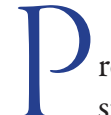

redhodno navedena evropska direktiva o avdiovizualnih medijskih storitvah (AVMS) se sklicuje na vsebine, ki bi lahko »resno škodovale fizičnemu, duševnemu ali moralnemu razvoju mladoletnikov, zlasti takšne vsebine, ki vsebujejo pornografijo ali neupravičeno nasilje«, in na vsebine, »ki bi utegnile škodovati fizičnemu, duševnemu ali moralnemu razvoju mladoletnikov«. Opredelitev je odnosna, kaže splošno na vsebine in vrsto škode v obravnavanem segmentu. Podoben pristop je ubral tudi še vedno veljavni slovenski medijski zakon iz leta 2006. A, kot že poudarjeno, zakon se nanaša zgolj na medije v ožjem pomenu besede, torej tiste, ki so informativne narave. Izdelki in storitve IKT/novi mediji niso vključeni oziroma so vključeni le, če so transmisija informativnega medija. Drugo zakonsko orodje za upravljanje fenomena potencialno škodljivih vsebin je za nove medije prav tako uporabno samo delno, in to na področju promocije komercialnih konstrukcij spolnosti in nasilja. Zakon o varstvu potrošnikov posega zgolj v oglaševanje (ZVPot-UPB2 2004, 15. čl.): »Oglaševanje ne sme vsebovati sestavin, ki povzročajo ali bi lahko povzročile telesno, duševno ali drugačno škodo pri otrocih, ali sestavin, ki izkoriščajo ali bi lahko izkoriščale njihovo zaupljivost ali pomanjkanje izkušenj.« Vsebine v tem primeru niso strukturirane, opredelitev škode delno povzema direktivo, a je namesto možnosti vpliva na »moralni razvoj« uporabljena splošna opredelitev »drugačna škoda«. Smiselno pomenljiv sklop v formulaciji se nanaša na lastnosti segmenta (»zaupljivost«, »pomanjkanje izkušenj«).

Pojmovanje določenih lastnosti otrok in mladoletnih, ki prispevajo $\mathrm{k}$ možnostim škode, je implicirano tudi v drugem regulacijskem orod- 
ju, ki pa je s področja kazenskega prava. Kazenski zakonik v obravnavi pornografske škode strukturira segment na dve skupini. Prva skupina v starosti do 15 let je opredeljena $v$ razmerju do diseminacije porna in dostopa do predstav, ki so pornografske. Druga skupina v starosti do 18 let (»mladoletna oseba«) se vzpostavlja v odnosu do vključenosti oziroma skozi zlorabo $\mathrm{v}$ produkciji in diseminaciji pornografskih ali drugačnih seksualnih materialov (KZ 1 2008, 176 čl.).

Pričujočo predstavitev lahko sklenemo z ugotovitvijo, da se potencialna škoda ne veže zgolj na starost in na vrsto vsebin, temveč tudi na značaj potencialnega oškodovanja, njegovo intenzivnost oziroma stopnjo in na določene, široko sprejete domneve o lastnostih otrok in mladoletnih. Pravnonormativne tematizacije implicirajo idejo o individualni škodi, četudi se z navedenimi predpostavkami nanašajo na družbeno skupino. V nasprotju s takim pristopom pa je po drugi strani že dolgo priznan (tudi v posameznih legislativah in jurisdikcijah) koncept družbene škode, zlasti v povezavi z etnično diskriminacijo in pornom iz perspektive spolov. Uveljavljajo ga strateški dokumenti, na primer resolucija Evropskega parlamenta, ki definira pornografijo skozi njen učinek; žanr opredeljuje kot mehanizem vzdrževanja neenakega položaja žensk v družbi (EP 1993, PV, PE 177.1241993, 57, v Baer, 1996: 56). Enako se v kanadski jurisdikciji, na primer, referenčne sodbe sklicujejo na škodo, povzročeno družbeni skupini (Šribar, 2006: 15, 160). Čeprav je v primerjavi s slovensko ta sodna praksa drugače koncipirana, ju je na področju regulacije pornografskih in drugih potencialno škodljivih, diskriminacijskih in sovražnih vsebin in odnosov dominantne koncepte zagotovo možno in tudi nujno soočati.

Družbeno napredne obravnave in upravljanja pornografije in konstrukcij nasilja so utemeljene v izvorih filozofije liberalizma. Ta odkriva pomen družbenih pogojev možnosti za enakost $\mathrm{v}$ kompetitivnosti na področju diskurzov (Mill, 1993) - dokler ti niso ustvarjeni, je treba upoštevati premoč komercialnih diskurzov o spolnosti in nasilju ter njihovo performativno silo; ukrepi potemtakem morajo biti naravnani v prid šibkejšim družbenim skupinam in k omejevanju močnejših. Tudi tradicionalne tirade o pravici do svobode izražanja pornografske spolnosti in drugih diskriminacijskih in sovražnih vsebin je treba soočiti z načelom enakih možnosti različnih družbenih skupin. Gre za nasprotujoče si principe človekovih pravic, pri čemer imajo nekateri med njimi manj izhodiščnih možnosti za uveljavljanje (Easton, 1994). Glede na so- 
dobna družbena razmerja in razlike v moči nosilcev in nosilk različnih diskurzov je tudi konfrontacija diskurza o svobodi izražanja s strani industrije zabave s pornoproducenti in distributerji na čelu in diskurza, ki uveljavlja načela človeške integritete in človekovih pravic otrok in žensk onkraj spopada med »puritansko moralno večino « in »liberalnim « tokom. A slednji, in ne ta domnevna »moralna večina «, je najbolj vpliven. Nosi ga vladajoči princip, ki oblikuje aktualno dominantno držo; na tem mestu jo imenujemo morala laissez faire. Morala, kot implicirano, ne more biti oziroma ni več zgolj v oblasti krščanske provenience, opredeljena je kot specifična naravnanost $\mathrm{v}$ okviru različnih etičnih sistemov, ki niso več vrednotno tradicionalno pogojeni (prim. Šribar, 2007).

Dimenzija družbene škode zaradi potencialno škodljivih vsebin in odnosov (novih) medijev v segmentu otrok in mladoletnih v EU ne dosega širokih teoretskih tematizacij, znanstvenih obravnav in nekaterih ponekod drugod že uveljavljenih strokovnih aplikacij; navedeno velja še posebej za Slovenijo. Analitični pristopi v znanosti in stroki v določenih primerih evidentno izražajo neobčutljivost za socializacijske vidike obravnavanih vsebin na ravni spola, seksualnosti in nasilja. Tako na primer se v kriminalističnem in empiričnem sociološkem govoru o pornografiji in konstrukcijah nasilja v izdelkih in storitvah IKT poudarja »ekstremna« pornografija, ki vključuje otroško pornografijo in »eksplicitno « pornografsko gradivo (na primer Wall, 2007: 103). Izhodišče je potemtakem še vedno »obscenost « v tradicionalnem pomenu, ki predpostavlja moralo kot občo družbeno vedenjsko normo, ukoreninjeno v krščanski religiji.

Koncept zaščite otrok in mladoletnih pred potencialno škodljivimi vsebinami, uveljavljen $\mathrm{v}$ pravnem diskurzu, in prevladujoča raziskovalna konceptualizacija »tveganj《/potencialne škode v novomedijskih razmerjih omogočata vrsto pristopov, med njimi tudi tiste prevladujoče, ki so povezani z epistemološko tradicionalnimi pojmovanji družbene strukture. Teme spola in spolne enakosti na področju seksualnosti skupaj z vlogo diskriminatornih tradicionalnih ospoljenj in diskriminatornih konstrukcij nasilja in pornografije ter njihovim učinkom v segmentu otrok in mladoletnih so zato v analizi marginalizirane. To pa je manko, ki bi ga bilo z namenom vzpostavljanja celovite znanstvene platforme za obravnavo in uravnavanje fenomena treba nujno zapolniti. $\mathrm{Na}$ ta način bi se vzpostavila platforma za širjenje strokovnega znanja, ki bi se moralo uveljavljati tako $\mathrm{v}$ pedagoškem procesu na ravni kompetenc 
pedagoškega kadra in v okviru »vzgoje« za medije ter »spolne vzgoje«. Tudi za starše kot pomemben (a ne poglaviten!) člen socializacije mladih se vzpostavijo možnosti za informiranost na področju le preko ustreznih informativnih točk in programov, torej posebej njim namenjenega izobraževanja. Ne nazadnje pa tudi država sama z ustrezno strokovno podloženimi mehanizmi regulacije in koregulacije postavlja referenčni okvir za pojmovanje in upravljanje obravnavane problematike na vseh področjih javnega/družbenega življenja.

\section{Platforma za izboljšanje otroških in mladostniških kompetenc na področju spolnosti, nasilja in novih medijev: »spolna vzgoja «}

Kabinetna raziskava in porocilo The Girl Child: Review of the Implementation by the Member States and the EU Institutions of the Beijing Platform for Action (Šribar in Ule, 2008) sta obdelala problematiko otrok v razmerjih IKT/novih medijev na dva načina: z obravnavo računalniških kompetenc in parametrov t. i. spolne vzgoje. Pregled raziskav o kompetencah otrok na področju računalniške tehnologije je pokazal, da ekspertne študije poudarjajo pomen novih medijev v umeščanju otrok v družbeno okolje; a hkrati je najbolj javno izpostavljen vidik varnosti. Sam koncept računalniških kompetenc potemtakem po nujnosti že vključuje sposobnost samozaščitnega vêdenja v kibernetskem prostoru. Mediji in izdelki/storitve IKT oziroma novi mediji so v študiji obravnavani tudi pri pregledu dejavnikov in kazalnikov spolnega zdravja. $Z$ analizo dobrih praks vzgoje in izobraževanja v državah EU na navedenem področju se je med drugim prav tam izpostavila tudi sprega nasilja in seksualnosti v družbi s konstrukcijami le-te v (novih) medijih.

Med predlogi indikatorjev za položaj deklic v EU so tudi parametri seksualnega izobraževanja v vzgojno-izobraževalnih sistemih. Ti med tematska merila vključujejo telesno samopodobo, ki je v argumentaciji predloga indikatorja povezana $\mathrm{z}$ učinki norm »ženskosti《in $\gg$ moškosti $\ll$ v tradicionalnih medijih in novih medijih. Poleg tega je v tematska merila vključena sprega spolnosti in nasilja, ki, kot že nekajkrat konstatirano, ni neodvisna od kulturnih, natančneje medijskih in drugih sodobnih komunikacijskih konstrukcij. 
Problematika porna in drugih konstrukcij sprege seksa in nasilja ...

Tabela 1: Merila za izobraževanje na področju seksualnosti.

\begin{tabular}{|c|c|c|c|c|c|c|}
\hline Status & \multicolumn{3}{|c|}{ obvezno } & \multicolumn{3}{|c|}{ izbirno } \\
\hline Državne ustanove & \multicolumn{2}{|c|}{$\begin{array}{l}\text { ministrstvo za } \\
\text { šolstvo }\end{array}$} & \multicolumn{2}{|c|}{$\begin{array}{l}\text { ministrstvo za } \\
\text { zdravje }\end{array}$} & \multicolumn{2}{|l|}{ drugo } \\
\hline Sodelovanje nvo & \multicolumn{3}{|c|}{ IPPF } & \multicolumn{3}{|l|}{ drugo } \\
\hline Implementacija & \multicolumn{3}{|c|}{ medpredmetna } & \multicolumn{3}{|l|}{ drugo } \\
\hline Medpredmetna & biologija & etika & filozofija & $\begin{array}{l}\text { sociolo- } \\
\text { gija }\end{array}$ & družba & drugo \\
\hline Avtonomni predmet & \multicolumn{6}{|c|}{ poimenovanje } \\
\hline $\begin{array}{l}\text { Vpliv nacionalne ideolo- } \\
\text { gije/epistemološke pre- } \\
\text { spektive }\end{array}$ & \multicolumn{3}{|c|}{ ne } & \multicolumn{3}{|c|}{$\mathrm{da} /$ katere } \\
\hline Vpliv religije & \multicolumn{3}{|l|}{ ne } & \multicolumn{3}{|c|}{$\mathrm{da} /$ katere } \\
\hline Metode & formalne & $\begin{array}{l}\text { interak- } \\
\text { tivne }\end{array}$ & vrstniške & igra vlog & video & drugo \\
\hline Ustreznost & \multicolumn{3}{|c|}{ evalvacija/nadzor } & \multicolumn{3}{|c|}{ minimalni standardi } \\
\hline Izvajalci/-ke & učitelji/-ce & $\begin{array}{l}\text { zdravniki/- } \\
\text { ce }\end{array}$ & $\begin{array}{l}\text { zdravni- } \\
\text { ške sestre/ } \\
\text { tehniki }\end{array}$ & $\begin{array}{l}\text { nvo } \\
\text { aktivisti/- } \\
\text { ke; } \\
\text { osebje } \\
\end{array}$ & $\begin{array}{l}\text { duhovni- } \\
\text { štvo }\end{array}$ & drugo \\
\hline Kompetence izvajalcev/-k & \multicolumn{3}{|c|}{ neobvezna izobrazba } & \multicolumn{3}{|c|}{ obvezna izobrazba/katera } \\
\hline Odziv na potrebe & \multicolumn{2}{|c|}{ lokalno } & \multicolumn{2}{|c|}{$\begin{array}{l}\text { kulturna raz- } \\
\text { nolikost }\end{array}$} & \multicolumn{2}{|c|}{ spol/gender } \\
\hline Naslovljene manjšine & $\begin{array}{l}\begin{array}{l}\text { ekonom- } \\
\text { skoizklju- } \\
\text { čeni }\end{array} \\
\end{array}$ & $\begin{array}{l}\text { begunci/ } \\
\text {-ke }\end{array}$ & $\begin{array}{l}\text { migranti// } \\
\text {-ke }\end{array}$ & $\begin{array}{l}\text { etnične } \\
\text { manjsisine }\end{array}$ & $\begin{array}{l}\text { telesnoalid } \\
\text { prikrajsani }\end{array}$ & \\
\hline Kvota šolskih ur & osnovn & šola & & srednja & šola & \\
\hline $\begin{array}{l}\text { Starost, pri kateri se izob. } \\
\text { začne }\end{array}$ & & & & & & \\
\hline
\end{tabular}




\begin{tabular}{|l|l|}
\hline \multirow{4}{*}{ Teme } & človeška anatomija / fiziologija / spolni razvoj \\
\cline { 2 - 3 } & $\begin{array}{l}\text { medosebni odnosi in čustva, privlačnost, intima, } \\
\text { spolna izraznost / aktivnost }\end{array}$ \\
\hline & zanositev, nosečnost, rojstvo \\
\hline & kontracepcija (vključno z rabo kondoma), abortus \\
\hline & varna spolnost / tveganja, spolno prenosljive bolezni \\
\hline & vloge spolov in seksualna enakost \\
\hline $\begin{array}{l}\text { spolna zloraba in nasilje, nasilje na zmenku, spolno } \\
\text { nadlegovanje }\end{array}$ \\
\hline \begin{tabular}{l} 
spolna usmerjenost \\
\hline telesna samopodoba
\end{tabular} \\
\hline
\end{tabular}

Vir: Šribar in Ule, 2008: 25.

Pričujoči predlog parametrov temelji na deskriptivnih kazalnikih seksualnega izobraževanja v Evropi, ki so bili vzpostavljeni v študiji Seksualno izobraževanje v Evropi (Sexuality Education in Europe, 2006)); narejena je bila v okviru projekta SAFE (Sexuality Education for Europe), ki ga je izvajala mednarodna nevladna organizacija IPPF (International Planning Parenthood Federation), podprla pa ga je evropska komisija. Čeprav celovita povezava med parametri seksualnega izobraževanja, družbeno-kulturnimi normami spolnega vêdenja, posredovanimi preko tradicionalnih in novih medijev, in konstruktivnim, samozaščitnim ali pa destruktivnim spolnim vedenjem iz obravnavane študije in njenih virov ni neposredno razvidna, vendarle kaže na nekatere relacije. Preverili smo jih $s$ tematiziranjem statusa seksualnega izobraževanja v državah članicah EU, pregledom njegovih vsebin in starostjo otrok, pri kateri se formalno in neformalno dejansko začne pouk.

V skladu z zgoraj navedeno primerjalno študijo je izobraževanje na področju spolnosti obvezno v Avstriji, Belgiji, na Češkem, Danskem, v Estoniji, na Finskem, v Franciji, Nemčiji, Grčiji, na Madžarskem, Irskem, v Latviji, Litvi, Luksemburgu, na Nizozemskem, Portugalskem, v Romuniji, na Slovaškem in Švedskem. Ker je prepoznana pomanjkljiva izobraženost izobraževalcev in izobraževalk in ne le otrok in mladine, se je Finska kot pozitivna izjema leta 2007 odločila, da morajo vse 
izobraževalne ustanove imeti/uvesti seminarje iz spolnega izobraževanja za pedagoške delavke in delavce.

Starost, pri kateri se formalno prične spolno izobraževanje, se razlikuje od države do države. Poglejmo skrajnosti - najnižjo in najvišjo starost. Na Portugalskem in v Veliki Britaniji se začenja pri petih letih, v Belgiji, Franciji, Grčiji, na Irskem v Luksemburgu ter na Švedskem pri šestih, na Cipru, v Italiji in Španiji pa pri štirinajstih letih.

Čeprav so vsebine v primerjalni študiji zgolj nanizane, pa že poimenovanje pokaže na koncipiranje predmeta poučevanja (kot sva predhodno že argumentirali). Na Nizozemskem je opredeljen kot »seksualno formiranje « in že sam naziv implicira pomembno tezo o družbeni in kulturni konstruiranosti spolnosti (ibid.: 66). Tudi začetek izobraževanja na Finskem, že v vrtcu, pred formalnim vstopom na predmetno področje, je možno brati skupaj s sodobno novomedijsko kulturo, ko se »erotika«, tj.porno chic podžanr, otrokom vsiljuje dnevno na mobilnih portalih, v tiskanih medijih, na plakatnih panojih in televiziji (ibid.: 41). Otroke je utemeljeno na ustrezen način zgodaj podučiti o pornografskih in pornografiziranih podobah spolnosti in njihovih neželenih učinkih ter jih opremiti $z$ alternativnimi informacijami. Enako velja za druge komercialne konstrukcije sprege nasilja in spolnosti ter spolno zaznamovanega nasilja. A glede na to, da je razpon med formalnim in dejanskim pričetkom obravnavanega izobraževanja velik in da zgodnja starost pričetka »spolne vzgoje « ne korespondira nujno s sodobno koncipiranostjo predmeta, je treba za vsako resno, četudi zgolj prvo presojo kakovosti vzeti vsaj tri dejavnike skupaj, status šolskega izobraževanja (oziroma oblikovanja kompetenc) na področju seksualnosti (obvezno, neobvezno), formalno in neformalno starost ob začetku »spolne vzgoje « ter poimenovanje. Prav tako so nezanesljivi tudi izolirani kazalniki učinkov spolnega izobraževanja. Ker se splet nasilja in spolnosti udejanja najpogosteje na manj vidne načine, lahko uporabimo le posreden in dokaj »neobčutljiv« indikator, ki kaže na osveščenost deklet in fantov v spolnem védenju. Vse države udeleženke $\mathrm{v}$ raziskavi, ki beležijo nizko rabo kontracepcije z izjemo Danske in Velike Britanije poročajo o pozni starosti pričetka dejanskega izobraževanja na področju seksualnosti. 
Tabela 2: Seksualno izobraževanje: status, starost, pri kateri se začenja formalno/ dejansko vključevanje.

\begin{tabular}{|c|c|c|c|}
\hline & $\begin{array}{l}\text { Obvezno spolno } \\
\text { izobraževanje }\end{array}$ & Starost - formalno & Starost - dejansko \\
\hline Avstrija & $\mathrm{da}$ & 10 & 11,6 \\
\hline Belgija & $\mathrm{da}$ & 6 & 12,5 \\
\hline Bolgarija & ne & 11 & 13,3 \\
\hline Ciper & ne & 14 & 1 \\
\hline Češka & $\mathrm{da}$ & 7 & 13,7 \\
\hline Danska & $\mathrm{da}$ & 12 & 12,2 \\
\hline Estonija & $\mathrm{da}$ & 10 & 1 \\
\hline Finska & da & 7 & 11,8 \\
\hline Francija & $\mathrm{da}$ & 6 & 13,1 \\
\hline Nemčija & $\mathrm{da}$ & 9 & 11,3 \\
\hline Grčija & $\mathrm{da}$ & 6 & 13,3 \\
\hline Madžarska & $\mathrm{da}$ & 10 & 12,8 \\
\hline Irska & $\mathrm{da}$ & 6 & 12,5 \\
\hline Italija & ne & 14 & 12,6 \\
\hline Latvija & $\mathrm{da}$ & 11 & 1 \\
\hline Litva & 1 & 1 & 1 \\
\hline Luksemburg & $\mathrm{da}$ & 6 & 1 \\
\hline Nizozemska & $\mathrm{da}$ & 13 & 12,1 \\
\hline Poljska & ne & 12 & 13,1 \\
\hline Portugalska & $\mathrm{da}$ & 5 & I \\
\hline Romunija & 1 & 1 & I \\
\hline Slovaška & $\mathrm{da}$ & 12 & 12,5 \\
\hline Španija & ne & 14 & 12,8 \\
\hline Švedska & $\mathrm{da}$ & 6 & 12,1 \\
\hline $\begin{array}{l}\text { Velika Bri- } \\
\text { tanija }\end{array}$ & da & $5 / 7$ & 12,1 \\
\hline
\end{tabular}

Vir: IPPF, 2006: 20.

Na področju spolnega zdravja otrok in mladoletnih so podatki za Slovenijo dostopni v okviru mednarodnega programa raziskav HBSC (Health Behaviour in School-aged Children), ki se izvaja pod okriljem svetovne zdra- 
vstvene organizacije (SZO). Tudi ta raziskovalna študija tveganja na področju spolnega zdravja se navezuje na problem slabe informiranosti (Brcar, $v$ Bajt in Gorenc, 2007: 174). K tveganemu vedenju se v skladu z virom prišsevajo »prezgodnji spolni odnosi; eden od njihovih dejavnikov je tudi slaba samopodoba in napačna predstava o pričakovanju druge osebe (Končnik-Goršič, 2004, v Bajt in Gorenc, ibid.). Respondenti in respondentke iz prvega in tretjega letnika srednjih šol, ki so odgovarjali na vprašalnik v letu 2004, 2.380 jih je bilo, so med drugim v nekaj manj kot tretjini primerov navedli, da so se odločili za prvi spolni odnos po naključju; dobra polovica jih je spolno aktivnih, raba kontracepcije je v primerjavi s povprečjem v državah EU visoka ${ }^{1}$ (Bajt in Gorenc, 2007: 175; IPPF, 2006: 22). Kljub temu je samozaščitno vêdenje omejeno na zaščito pred neželeno nosečnostjo, saj je uporabo kondoma, ki ima kompleksno varovalno funkcijo, navedla le približno polovica vključenih v raziskavo, ki so bili spolno aktivni Viri informiranja srednješolk in srednješolcev o seksualnosti so se po pričevanju (2004) razlikovali od tistih izpred osmih let, saj so takrat bili glavna referenca za informiranje starši in vrstnice oziroma vrstniki. Mladi so v skladu s citirano študijo navedli poleg strokovnih tudi druge vire informacij (Bajt in Gorenc, 2007: 174), vendar vloge popularnih, pornografsko zaznamovanih informacij in učinkov samega porna spričo podinformiranosti in slabe osveščenosti na tem mestu ne moremo argumentirano izpostaviti.

Glede na rezultate predstavljene študije so fantje prej spolno aktivni, hkrati pa nezanesljivi pri zaščiti (ibid.: 180). Enakomerna fokusiranost na dekleta in fante je prednost te raziskave. Siceršnji poudarek na dekletih v mnogih raziskavah o seksualnosti in človeški reprodukciji (zgodnje nosečnosti in porodi, abortusi) je, na to je vsekakor nujno opozoriti, destruktiven $\mathrm{z}$ vidika utrjevanja ekskluzivno ženske odgovornosti na področju človeške reprodukcije.

Če se tu vrneva k novim medijem, predhodno navajana študija $E U$ Kids On Line prav tako izpostavlja segment dečkov in fantov kot občutljiv (ne le segment deklic in deklet); gre za lahkotnost sprejemanja vsebin in lahkotnost novomedijskih aktivnosti. V skladu s povzetkom pregleda stanja v državah EU je možno zatrditi, da fantje rajši od deklet iščejo žaljive in nasilne vsebine ter dostopajo do pornografije, bolj so nagnjeni k osebnemu srečanju osebe, $s$ katero so prej vzpostavili virtualni stik, hkrati so tudi manj premišljeni v razkrivanju osebnih podatkov. Ker so dekleta pogosteje tista, ki dobivajo žaljive, nasilne in pornomateriale, neželene spolne

\footnotetext{
${ }^{1}$ Vprašanje se je nanašalo na rabo kontracepcije pri zadnjem spolnem odnosu. Slovenski in evropski podatki so starostno primerljivi, študija IPPF je namreč preverjala vedenje petnajstletnikov/-ic.
} 
komentarje ter zahteve po razkritju osebnih podatkov (Hasebrink et al., 2008: 62), je možno ponovno argumentirano zatrditi, da status in vloge spolov v novomedijskih razmerjih ne odstopajo od tradicionalnih spolnih položajev in vlog navkljub močno prisotnemu mnenju, da nove informacijsko-komunikacijske tehnologije prinašajo nove, bolj demokratične možnosti oziroma modalitete socializacije. Posebej za Slovenijo ni teh podatkov, smemo pa sklepati, da je slika podobna. Glede korelacije med srečevanji s potencialno škodljivimi vsebinami in pripravljenostjo otrok na ustrezen odziv v situacijah spletnih tveganj pa smo v povprečju EU (ibid.: 43).

Iz predstavljenega nabora podatkov in interpretacij je razvidno, da je utemeljeno oblikovati spolno senzibilne platforme za izobraževanje deklet in fantov na področju seksualnosti in tudi nasilja v povezavi s spolnostjo; ob tem je treba upoštevati pomen in vlogo družbeno-kulturno posredovanih norm, ki pa se oblikujejo zlasti skozi nove medije. Širina in kompleksnost pristopa $\mathrm{k}$ t. i. spolni vzgoji, ki vključuje tako problematiko s spolnostjo in spoli povezanega nasilja kot novih medijev, je nastala zaradi velikega manka »vzgoje za medije« v sistemu VIZ, izjemno prisotne pornografizacije kulture v Sloveniji, ki utrjuje spolno diskriminatorne predstave o vlogi spolov v seksualnosti in heteronormativno matrico, ter splošne podinformiranosti in podreguliranosti na področju priznano spornih novomedijskih vsebin in odnosov. Glede na pričujočo refleksijo bi veljalo razmisliti tudi v smeri treh dopolnil izgrajevanja kompetenc odraščajočih v okviru »spolne vzgoje « in njenih tematik. Problematiko spola bi bilo treba razširiti na različna ospoljenja (spol kot pluralna kategorija, ki vključuje transspolne osebe, angl. transgender). Tako tematsko izhodišče je pomembno ne le zaradi kulturnih konstrukcij spola, ki postajajo diverzificirane, temveč tudi zaradi vrojenih dimorfnih spolnih znakov (medspolne osebe, angl. intersex), $\mathrm{ki}$ - če te pojavnosti niso pozitivno institucionalizirane - prinašajo s sabo stigmo; ta seže tudi do zanikanja obstoja. Prav tako bi bilo konstruktivno razmisliti o tematski širitvi parametrov izobraževanja otrok in mladih na področju spolnosti z novomedijskimi konstrukcijami seksualnosti in sprege spolnosti in nasilja, morebiti v registru telesne podobe ali vloge spolov in seksualne enakosti, še bolje pa kot avtonomno topiko. Tretje dopolnilo zahteva izjemno občutljivo problematiko drugih družbenih manjšin (poleg spolnih), zato ga predstavljava temeljiteje, vključujoč mednarodne norme.

Poglavitna strateška izhodišča za oblikovanje politik v okviru OZN in EU, ki se usmerjajo na položaj in možnosti otrok in mladih, dajejo poudarek tudi na specifične marginalizirane skupine, predvsem na revne deklice 
in dekleta. A prav tako je pri formiranju kompetenc otrok in mladostnic ter mladostnikov na področju spolnega izobraževanja $\mathrm{v}$ povezavi z (novimi) mediji poleg starostne, spolne, razredne in geografske strukturiranosti segmenta pomembno upoštevati strukturiranost iz perspektive pogosto spregledanih drugih obrobnih skupin (telesne kompetence, etnična pripadnost, državljanski status). Podatki za devetnajst držav EU, ${ }^{2}$ ki so bili zbrani v času slovenskega predsedovanja Uniji, kažejo, da samo Italija in Belgija pri načrtovanju seksualnega izobraževanja v šolah vključujeta kompleksno manjšinsko perspektivo, natančneje hendikepirane, otroke migrantov in migrantk, pripadnice in pripadnike etničnih manjšin, revne in begunske otroke (Šribar in Ule, 2008: 59). Glede na to, da imajo pripadnice in pripadniki močno ali tudi intersekcijsko prikrajšanih slojev manj družbenih in kulturnih možnosti nasploh, je nevarnost za neposredno dojemanje in učinkovanje spolno nasilnih konstrukcij na življenjsko empirijo tu največja. V okviru tretjega tematskega dopolnila (spolnost in družbene skupine) $\mathrm{k}$ parametrom t. i. spolne vzgoje zato predlagava naslednje teme:

- kulturne razlike v pojmovanju spolnosti (in telesa)

- vloga spolnosti v reproduciranju različnih družbenih prikrajšanosti (zlasti revščine)

- problematika načela tolerance do drugačnih kulturnih navad $\mathrm{v}$ spolnosti $\mathrm{z}$ vidika poseganja $\mathrm{v}$ integriteto druge/-ga.

Preden končava sklop o pogojih prenove »spolne vzgoje «, tako da bo ta lahko prispevala k kompetencam otrok na področju spolnosti, nasilja in novih medijev, predstavljava še nekaj primerov dobrih praks z vidika priporočenih tematik. Povzeti so iz raziskave Nacionalne fundacije za raziskave na področju izobraževanja Anglije in Walesa (Sex and Relationship Education in Other Countries), ob tem pa so naju zanimali predvsem parametri tistih držav, ki teme razvrščajo glede na primernost za določene starostne skupine. Pri navajanju sva iz praktičnih razlogov selektivni in osredotočeni na omejeno starost otrok oziroma učenk in učencev.

Primer Avstralije (država Victoria) pokaže, da izobraževanje na področju spolnosti (to poteka v okviru predmeta zdravje in izobraževanje o fizičnem telesu) v starostni skupini med 12 in 14 let poleg informacij o spremembah $\mathrm{v}$ adolescenci, preverjanja vpliva družine na identiteto in vrednote; oblikovanje predstav o zdravi spolnosti in zdravem življenju vključuje tudi tematizacijo družbeno posredovanih vrednot in njihovih zani-

${ }^{2}$ Gre za Avstrijo, Belgijo, Ciper, Češko, Dansko, Estonijo, Finsko, Nemčijo, Grčijo, Madžarsko, Italijo, Latvijo, Litvo, Malto, Nizozemsko, Romunijo, Slovaško, Slovenijo in Veliko Britanijo. 
kanj (»kaj je dobro in kaj slabo «) ter vprašanje dostopnosti do informacij (2009: 3). Primer Kanade na področju izobraževanja o spolnosti v segmentu štirinajstletnikov in štirinajstletnic med ostalim (človeška reprodukcija, spolne razlike $\mathrm{v}$ adolescenci, spolne bolezni) kaže na temo dejavnikov identitete, ki učinkujejo na zdravo odločanje v zvezi s spolnostjo (ibid.: 6). Tudi dve evropski državi, Norveška in Portugalska (slednja kljub močni katoliški tradiciji), vnašata v konceptualizacijo izobraževanja na področju seksualnosti sodobne teme. Norveška v starostni skupini dvanajst- in trinajstletnikov obravnava, denimo, spolne orientacije in različne spolne identitete ter družinske oblike (ibid.: 29); Portugalska se v segmentu otrok v starosti med enajst do trinajst let ne izogiba tematizaciji povezanosti med spolnimi vlogami in seksualnostjo (ibid.: 32). Med izbranimi primeri se posredno na (novo) medijsko kulturo nanaša Avstralija $z$ družbenim posredovanjem vrednot in norm in vprašanjem informiranja. Dobre prakse pa, ki jih posreduje študija IPPF, izpostavljajo tudi pomen populacijske raznolikosti v okviru izobraževanja/oblikovanja kompetenc na področju spolnosti (Nemčija) in za manjšine senzibilen pristop k izobraževanju na področju spolnosti (Luksemburg) (IPPF, 2006: 47, 64).

Merila »spolne vzgoje«, ki veljajo v EU in ki sva jih v pričujoči študiji že predstavili, ne vključujejo eksplicitnih evalvacij posameznih možnosti, ki jih ponuja določeni parameter. To je zagotovo smotrno, saj gre za naddržavna merila, kjer veliko možnih zastavitev ne more biti pozitivno ali negativno ovrednoteno, še posebej, če niso kontekstualizirane. Pri aplikaciji meril v Slovenijo bo zato vsekakor treba izdelati spremno študijo $s$ kompleksno analizo dejavnikov, ki opredeljujejo določeno izbiro pri posameznem dejavniku kot konstruktivno ali družbeno regresivno. Najznačilnejši v tem smislu so parametri:

- vpliv nacionalne ideologije/epistemološke perspektive: ne/da (katere)

- vpliv religije: ne/da (katere)

- izvajalci/-ke: učitelji/-ce, zdravniki/-ce zdravniške sestre/tehniki, (aktivistke/-i, osebje), duhovništvo, drugo. 
pričujočem tekstu sva želeli pokazati na koncepte in druge razsežnosti obravnave otrok in mladih v (novo)medijskih razmerjih. Pri tem sva se osredotočili na tiste potencialno škodljive vsebine in odnose, ki jih razumemo in razlagamo v okviru pornografije in nekaterih drugih, imanentno nasilnih konstrukcij spolnosti ter konstrukcij ospoljenega in seksualiziranega nasilja. Poleg definicij same snovi - tako vsebin in novomedijskih relacij - sva izpostavili možne pristope $\mathrm{k}$ študiju otrok in mladine $\mathrm{v}$ (novo)medijskih razmerjih ter navedli nazoren primer aplikacije znanj v izobraževalno prakso v okviru »spolne vzgoje«. Na tak pristop so naju navedle med drugim tudi izkušnje z zaposlenimi v pedagoškem poklicu, ki sva jih pridobili v letu 2009 in 2010 pri izvedbi programa »Profesionalno usposabljanje strokovnih delavcev v vzgoji in izobraževanju na področju socialnih in državljanskih kompetenc v letih 2008-2011«; podobne izkušnje pa sva pridobivali tudi že prej v okviru programa stalnega strokovnega spopolnjevanja»Vrtec, možnost izbire, drugačnost «, ki se je izvajal na Filozofski fakulteti v Ljubljani in na nekaterih drugih lokacijah v Sloveniji. Vzgojiteljice in vzgojitelji, učiteljice in učitelji, profesorice in profesorji slovenskih vrtcev in osnovnih ter srednjih šol so praviloma poročali o spolno nasilnem vedenju in seksualiziranem nasilju ob uporabi izdelkov in storitev IKT ter klasičnih medijev tako v vrstniškem krogu kot v okviru šolske hierarhije.

Obravnavano sprego spolnosti in nasilja sva razbrali v različnih, tu že predstavljenih oblikah: šlo je za spolno nadlegovanje s fotografiranjem deklet $\mathrm{v}$ intimnih situacijah brez dovoljenja in $\mathrm{z}$ distribuiranjem materiala 
preko storitev mobilne telefonije, za prejemanje žaljivih vsebin glede telesne pojavnosti preko multimedijskih sporočil, za izpostavljanje porno chic materialov v šolskem okolju na obeh stopnjah izobraževanja, za konzumpcijo pornografije na šolskih računalnikih in za vsiljevanje pornografskih vsebin z mobilnih portalov vrstnikom. Ob tem naj navedeva nekaj fragmentov iz šolskega življenja zunaj neposredne uporabe tradicionalnih medijev in IKT, za katere meniva, da so bili povezani z vulgarizmi, diskriminacijami in sovražnostmi obravnavanih vsebin in relacij:

- nadvladovanje profesoric s spolnim nadlegovanjem strani dijaka

- vrstniško postavljanje $s$ »kompetencami« na področju spolnosti

- dekliško posnemanje pornografiziranih podob v oblačenju in vedenju.

Kljub temu, da pričujoča študija predstavlja izhodišče za nadaljnje raziskovalno in strateško delo, pa gotovo pomeni tudi že prispevek k vzpostavljanju norm v družbenem odnosu do pornografskih in drugih komercialnih konstrukcij spolnosti ter konstrukcij spolnega ter seksualiziranega nasilja. Čeprav bi lahko s svojim delom prispevali k opolnomočenju in informiranosti posameznih zaposlenih v pedagoškem poklicu, pa meriva predvsem na vlogo države in sfero znanosti in stroke. $Z$ vidika konstruktivne socializacije otrok in mladoletnih v razmerjih (novih) medijev se ta lahko in mora utrditi na mnogih ravneh, na različnih področjih in na mnoge načine, denimo:

- v prepoznavanju potreb otrok in mladoletnih $\mathrm{v}$ šolskih politikah

- pri oblikovanju regulacije, oziroma natančneje, skozi vzpostavitev celovitega sistema koregulacije potencialno škodljivih (novo)medijskih vsebin in odnosov

- ob večji pomoči nevladnim organizacijam pri vzpostavitvi kibernetskih in drugih informacijskih točk, ki bi bile inovativne in širše prepoznavne in promovirane

- pri izvajanju izobraževalnih seminarjev za starše in otroke ter mladoletne, ki bi bili v razmerju do (novih) medijev proaktivni in bi vključevali starševsko soudeležbo in udeležbo otrok in mladih

- z oblikovanjem proaktivne politike lokalnih oblasti, ki bi vključevala analizo in strateški odnos do točk oglaševanja potencialno škodljivih vsebin v urbanem okolju

- z uveljavljanjem tematik spola, spolnosti, nasilja in (novih) medijev v oblikovanju raziskovalnih politik 
- z načrtovanjem in izvajanjem državnih kampanj, namenjenih ozaveščanju in informiranju, ki bi presegle običajno, suhoparno in »grozilno $\ll$ raven

- z organizacijsko in finančno podporo za izvedbo strokovnih seminarjev in kampanj, namenjenih medijem in entitetam na področju IKT - s poudarkom na operaterjih mobilne telefonije, ponudnikih vsebin na mobilnih portalih in izdajateljih programskih vsebin.

Nanizane dejavnosti je treba izoblikovati na podlagi celovite argumentacije in ob soustvarjanju sprejemljivega kulturnega okolja. Namesto sklepa naj zato formulirava raziskovalne in strateške naloge ter cilje:

- prepoznavanje oblik povezanosti med potencialno škodljivimi vsebinami IKT in medijev in percepcijo, stališči ter vedenji otrok in mladoletnih v Sloveniji

- tematizacija zaščite otrok in mladoletnih pred potencialno škodljivimi vsebinami IKT in medijev $\mathrm{z}$ vidika spolov v sistemu vzgoje in izobraževanja

- tematizacija zaščite otrok in mladoletnih pred potencialno škodljivimi vsebinami IKT in medijev $\mathrm{z}$ vidika spolov in telesne samopodobe v okviru tiste zdravstvene oskrbe, ki se izvaja v povezavi s šolami

- dekonstrukcija neoliberalnih pojmovanj o regulaciji potencialno škodljivih vsebin in promocija s tem povezanih znanstvenih dognanj $\mathrm{v}$ javnosti

- uveljavljanje najsodobnejših koncepcij koregulacije in njihova promocija z vidika smotra in učinkov

- sodelovanje znanosti s stroko in nevladnim sektorjem s ciljem razvoja Sloveniji prilagojenih konceptov za delovanje na obravnavanih področjih

- vzpostavitev povezovalne točke $\mathrm{z}$ namenom pregleda slovenskih raziskav na vseh obravnavanih področjih v okviru medresorske izvršne oblasti;

- tematizacija potencialno škodljivih vsebin v okviru urbanih geografij s primeri dobrih strateških praks

- permanentna javna diskusija o uredniških politikah (novih) medijev in poslovnih strategij, ki so vključene v oblikovanje izdelkov in storitev IKT/novih medijev z vidika potencialno škodljivih vsebin in zaščite otrok in mladoletnih, zlasti na področjih spolov, spolnosti in nasilja. 

knjigi tematizirava, problematizirava in predlagava izhodišča za obravnavo in regulacijo konstrukcij (porno)spolnosti in nasilja $\mathrm{v}$ medijih, predvsem pa v vsebinah produktov in storitev informacijsko-komunikacijske tehnologije (IKT) oz. novih medijev. Svoj predmet raziskujeva skozi analizo diskurzov, skozi katere je opredeljen v javnosti in v vzgojno-izobraževalnem procesu (medijski, legislativni in regulativni, javnomnenjski, pedagoški, poljudno medicinski in poljudno socialno-psihološki govor). V raziskovanje sva pritegnili orodja in dognanja različnih znanstvenih področij in disciplin, saj je tema kompleksna in povezana $\mathrm{z}$ mnogimi vidiki družbenega življenja.

Za temeljno teoretsko ogrodje sva vzeli feministično epistemologijo kot projekt, ki si prizadeva razložiti povezave med konstrukcijo vednosti ter družbenimi in političnimi interesi. Poudarek je tu na spolu kot osrednji kategoriji v razpravah in rekonstrukcijah epistemskih praks, norm in idealov. Feministični pristop $\mathrm{k}$ epistemologiji se poleg tega nagiba $\mathrm{k}$ poudarjanju načinov, na katere je spoznavajoča/-či posamična in konkretna, materializirana oseba (ne pa abstraktna in univerzalna). Feministične epistemologije jemljejo resno moduse, na katere so spoznavajoči oziroma vedoči vpleteni v družbene odnose, ki so generalno hierarhični in kulturno ter zgodovinsko specifični.

Primarno sva si prizadevali obrazložiti epistemološke razsežnosti fenomena in oblikovati sodobne koncepte za soočanje z njim. Interdisciplinaren pristop pa je argumentiran tudi $\mathrm{z}$ aplikativnim namenom projekta, ki je v vzpostavitvi znanstvenih in strokovnih izhodišč za obravnavo kon- 
strukcij nasilja in (porno)spolnosti v medijih in IKT v šolskem kurikulumu in neformalnih programih (v okviru t. i. spolne vzgoje ter vzgoje za medije in IKT), in v znanstveno-strokovni platformi za konfrontacijo s proliferacijo konstrukcij nasilja in spolnosti v okviru koregulativnega sistema ( $v$ pravnem okviru zaščite otrok in mladoletnih pred potencialno škodljivimi vsebinami). Ob tem reflektirava tudi spornost/uporabnost obstoječe prevlade kvantitativnih metod.

Podrobneje se osredotočava na polje vzgoje in izobraževanja ter preko temu polju lastnih konceptov (kurikulum, prikriti kurikulum, uradna vednost) poskušava identificirati problematiko, skupaj z dobrimi/slabimi praksami doma in v tujini. Ugotavljava, da je sfera šolskega informiranja in vzgoje mladih na področju seksualnosti in spolnega zdravja zelo nerazdelana oziroma pomanjkljivo obravnavana.

Ravno to - (ne)kompetence otrok in mladih glede spolnosti in odnosov - pa je tudi točka, na kateri povezujeva obe področji, ki normirata odraščanje in na katerih se dogaja in obnavlja spolno diskriminatorno ospoljenje. Kot je razvidno, gre za področji šolanja in (novih) medijev, ki na diferencirane načine vključujeta pojavnosti spolno zaznamovanega nasilja in pornografizirane seksualnosti. Konvergenco med (novo)medijskimi normami, ki otrokom in mladim predpisujejo, kako odraščati $\mathrm{v} \gg$ ženskost « in $\gg$ moškost « in kako se »vpisati« v spol skozi seksualnost - in zapovedmi prikritega kurikuluma in vrstniške šolske kulture refleksivno uokvirjava na različne načine, najprej skozi predstavitev določenih konceptov (spol, seksualnost, nasilje), nato metodološko (denimo s pomočjo feministične antropologije izobraževanja) in končno skozi niz primerov iz šolskega okolja.

V monografijo, ki vsebuje tako izhodiščne, epistemske obrazložitve kot tudi povsem konkretne problematike, nanašajoče se na mladostniške izkustvene prakse in na regulacijske ter izobraževalne politike (zlasti t. i. spolne vzgoje), pa sva vključili še vrsto tem in hipotez, ki čakajo na nadaljnjo obravnavo. Navsezadnje je delo osmišljeno predvsem kot temelj nadaljnjih elaboracij na ravni znanstvenega raziskovanja in hkrati tudi že prevajanja $\mathrm{v}$ regulacijske in izobraževalne strategije in nato tudi njihovega sprotnega preverjanja. 


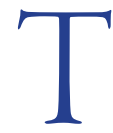

he book discusses, sets out the problems regarding, and proposes starting points for discussion and regulation of the construction of (porno)sexuality and violence in the media, particularly in the contents of information and communications technology (ICT) products and services, i.e. new media. We investigate our subject through discourse analysis, through which it is defined in public and in the education process (media, legislative and regulatory, public-opinion, educational, popular medicine and popular social-psychology discourse). Our research utilised tools and findings from various scientific fields and disciplines, as the topic is complex and associated with many aspects of social life.

We adopted feminist epistemology as the basic theoretical framework, as a project that attempts to explain the connection between the construction of knowledge and social and political interests. The emphasis here is on gender as a main category in discussion and reconstruction of epistemological practices, norms and ideals. In addition, feminist approach to epistemology tends to emphasise the ways in which knowers are particular and concrete (rather than abstract and universalizable). Feminist epistemologies take seriously the ways in which knowers are enmeshed in social relations that are generally hierarchical and historically and culturally specific.

We primarily attempted to explain the epistemological dimension of the phenomenon and to formulate modern concepts for dealing with it. The interdisciplinary approach is also supported by the applied intent of the project, which is to establish the scientific and professional starting points for discussion of construction of violence and (porno)sexuality in media 
and ICT in the school curriculum and informal programmes (within the framework of so-called sex education and media and ICT education), and a scientific-professional platform to confront the proliferation of constructions of violence and sex within the framework of a co-regulatory system (in the legal framework of protection of children and adolescents against potentially harmful content). At this point we also reflect upon the controversy/usefulness of the existing prevalent quantitative methods.

We focus in some detail on the field of education, and through concepts specific to this field (curriculum, hidden curriculum, official knowledge) we attempt to identify the problem, together with cases of good/bad practices at home and abroad. We conclude that the sphere of school information and education for young people in the area of sexuality and sexual health is very insufficiently analysed and inadequately discussed.

It is precisely this - the (in)competence of children and young people with regard to sexuality and relationships - that is the point by which we connect two areas that standardise growing up and at which discriminatory gendering practices occur and renew. As is clear, these are areas of education and new media that in differentiated ways include the phenomena of gender-specific violence and pornographised sexuality. The convergence between (new-) media norms - which ascribe to children and young people how to grow up into "femininity" and "masculinity" and how to "enrol" in gender through sexuality - and the requirements of the hidden and peer school culture is reflexively framed in different ways, first through presentation of certain concepts (gender, sexuality, violence), then methodologically (for instance with the aid of feminist anthropology of education) and finally through a series of examples from the school environment.

The monograph, which contains both initial, epistemological explanations as well as entirely concrete problems pertaining to adolescent experiential practice and to regulation and education policy (particularly socalled sex education), also includes a series of themes and hypotheses that await further consideration. Last but not least, the work is intended primarily as the basis for further elaboration on the level of scientific research and at the same time also translation into regulation and education strategies and subsequent ongoing verification. 


\section{Viri}

Bahovec, E. D., et al. (1999). Kurikulum za vrtce, Ljubljana: Ministrstvo za šolstvo in šport.

Fausto-Sterling, A. (1992). Myths of Gender. Biological Theories about Men and Women, New York: Basic Books.

Given, L. M. (2008) (ur.). The Sage Encyclopedia of Qualitative Research Methods, vol. 1 in 2, Los Angeles, London, New Delhi, Singapore: Sage.

Jaggar, M. A. (1991). Feminist Ethics. V: Becker, L. (ur.). Encyclopaedia of Ethics, London: Garland Publishing.

Johnson, J. A. (2008). Everyday Pornographies: Pornification and Commercial Sex. Prispevek na konferenci Globalization, Media and Adult/ Sexual Content: Regulation and Research, 29.-30. september, Atene.

Končnik-Goršič, N. (2004). Moj otrok odrašča, Ljubljana: Mladinska knjiga. Košir, M., Erjavec, K., in Volčič, Z. (2006). Učni načrt. Izbirni predmet: program osnovnošolskega izobraževanja. Vzgoja za medije: tisk, radio, televizija, Ljubljana: Ministrstvo za šolstvo, znanost in šport, Zavod $\mathrm{RS}$ za šolstvo.

Krek, J. (ur.) (1995). Bela knjiga o vzgoji in izobraževanju v Republiki Sloveniji, Ljubljana: Ministrstvo za šolstvo in šport.

Kuhar, R. (2010). O tišini in indoktrinaciji. Šolski razgledi, LXI/11, 6.

Šribar, R. (2009). Vpliv medijev in IKT na spolno nasilno vedenje. Predavanja in delavnice v osnovnih in srednjih šolah, projekt Profesional- 
no usposabljanje strokovnih delavcev v vzgoji in izobraževanju v letih 2008/2011 na področju socialnih in državljanskih kompetenc, tematski sklop Prepoznavanje in preprečevanje nasilja, januar-avgust, Pedagoška fakulteta, Ministrstvo za šolstvo in šport RS.

Šribar, R., in Ule, M. (2008). Status and Social Opportunities of the Girl Child: Expert Study, Ljubljana: University of Ljubljana, Faculty of Social Sciences.

Verčkovnik, T., et al. (2002). Biologija. Učni načrt: program osnovnošolskega izobraževanja, Ljubljana: Ministrstvo za šolstvo, znanost in šport, Zavod RS za šolstvo.

Vrdlovec, Z. (2007). »Snuff« civilizacija. Dnevnik, 13. 1. 2007.

\section{Literatura}

Adams, M., Bell, L., in Griffin, P. (2007) (ur.). Teaching for Diversity and Social Justice, Taylor \& Francis.

Alldred, P., in David, M. E. (2007). Get Real About Sex: The Politics and Practice of Sex Education, Buckingham: Open University Press.

Allen, L. (2004). Beyond the Birds and the Bees: Constituting a Discourse of Erotics in Sexuality Education. Gender and Education, XVI/2, $151-167$.

Allen, L. (2008). Poles Apart? Gender Differences in Proposals for Sexuality Education Content. Gender and Education, XX/5, 435-450.

Anderson, A. C., Gentile, A. D., Buckley, E. K. (2006). Violent Video Game Effects on Children and Adolescents, Oxford in New York: Oxford University Press.

Anderson, E. (1995). Feminist Epistemology: An Interpretation and a Defense. Hypatia, X/3, 50-84.

Annandale, E. (2008). Women's Health and Social Change, New York in London: Routledge.

Antić Gaber, M. (2007). Poklicne kariere slovenskih političark. V: Sedmak, M., in Medarič, Z. (ur.). Med javnim in zasebnim: Ženske na trgu dela, Koper: Založba Annales, 111-130.

Anyon, J. (1983). Intersections of Gender and Class: Accommodation and Resistance by Working-Class and Affluent Females to Contradictory Sex-Role Ideologies. V: Barton, L., in Walker, S. (ur.). Gender, Class, and Education, Sussex, England: Palmer Press, 19-38. 
Apple, M. W. (1992). Between Moral Regulation and Democracy: The Cultural Contradiction of the Text. The School Field, III/1-2, 49-76.

Ariès, Ph. (1991). Otrok in družinsko življenje v starem režimu, Ljubljana: Škuc in Znanstveni inštitut FF.

Arnot, M., in Mac an Ghaill, M. (2006). (Re)contextualizing Gender Studies in Education. V: Arnot, M., in Mac an Ghaill, M. (ur.). The RoutledgeFalmerReader in Gender and Education, Milton Park: Routledge, 1-14.

Attwood, F. (2007). No Money Shot? Commerce, Pornography and New Sex Taste Cultures. Sexualities, X/4, 441-456.

Austin, J. (1990). Kako napravimo kaj z besedami, Ljubljana: Škuc in Filozofska fakulteta.

Baer, S. (1996). Pornography and Sexual Harassment in EU. V: Elman, A. R. (ur.). Sexual Politics and the European Union, Providence in Oxford: Berghahn Books, 51-65.

Bahovec, E. D. (1992) (ur.). Vzgoja med gospostvom in analizo, Ljubljana: Krt.

Bahovec, E. D. (1996). Raziskava »Učene ženske«. Delta, II/1-2, 107-116.

Bahovec, E. D. (2007). Freud, ženska in popotnikova senca, Ljubljana: Delta.

Bahovec, E. D., in Bregar Golobič, K. (2004) (ur.). Šla in vrtec skozi ogledalo, Ljubljana: DZS.

Bajt, M., in Gorenc, M. (2007). Spolno vedenje: Uvod. V: Jeriček Klanšček, H., Lavtar, D., in Pokrajac, T. (ur.). $Z$ zdravjem povezano vedenje $v$ šolskem obdobju: HBSC Slovenija 2006. Ljubljana: Inštitut za varovanje zdravja Republike Slovenije, 173-181.

Baudrillard, J. (1999). Simulaker in simulacija. Popoln zločin, Ljubljana: Študentska založba.

Beasley, C. (2005). Gender \& Sexuality: Critical Theories, Critical Thinkers, London, Thousand Oaks in New Delhi: Sage Publications.

Beauvois, J. L. (2000). Razprava o liberalni sužnosti: Analiza podrejanja. Ljubljana: Krtina.

Benveniste, É. (1988). Problemi splošne lingvistike I., Ljubljana: Škuc in Filozofska fakulteta.

Boldin, M. (2008). Sistem koregulacije na preizkušnji. Medijska preža, 32$33,50-51$.

Boyle, K. (2005). Media and Violence: Gendering the Debates, London: Thousand Oaks, New Delhi: Sage 
Braidotti, R. (1996). Patterns of Dissonance: A Study of Women in Contemporary Philosophy, Cambridge in Oxford: Polity Press.

Braidotti, R. (2002). Identity, Subjectivity and Difference: A Critical Genealogy. V: Griffin, G., in Braidotti, R. (ur.). Thinking Differently: A Reader in European Women's Studies. London in New York: Zed Books, $158-180$.

Brcar, P. (2005). Zdravje otrok, mladostnikov in mladostnic. V: Črnak Meglič, A. (ur.). Otroci in mladina v prehodni družbi. Ljubljana: Ministrstvo za šolstvo in šport, Aristej.

Brooks, A. (1997). Postfeminisms. Feminism, Cultural Theory and Cultural Forms, London in New York: Routledge.

Brown, B. (1981). A Feminist Interest in Pornography - Some Modest Proposals «. $m / f, 5-6,5-18$.

Browning, L. D. (2007) (ur.). Adolescent Identities, New York in London: Routledge.

Buckingham, D. (2000). After the Death of Childhood. Growing Up in the Age of Electronic Media, Cambridge: Polity Press.

Butler, J. (2001). Težave spolom: feminizem in subverzija identitete, Ljubljana: Škuc.

Campbell, K. (2004a). The Promise of Feminist Reflexivities: Developing Donna Haraway's Project for Feminist Science Studies. Hypatia, IXX/1, 162-182.

Campbell, K. (2004b). Jacques Lacan and Feminist Epistemology. Routledge: London in New York.

Check, J. V. P. (2001). The Effect of Violent Pornography, Nonviolent Dehumanizing Pornography, and Erotica: Some Legal Implications from a Canadian Perspective. V: Itzin, C. (ur.). Pornography: Women, Violence and Civil Liberties, Oxford in New York: Oxford University Press, 350-358.

Connel, R. (2003). Masculinities, Change, and Conflict in Global Society: Thinking about the Future of Men's Studies. The Journal of Man's Studies, XI/3, 249-266.

Coppock, V., Haydon, D., in Richter, I. (1995). The Illusions of »Post-Feminism «. New Women, Old Myths, Abingdon: Taylor and Francis.

Currie, D. H. (1992). Subject-ivity in the Classroom: Feminism Meets the Academe. Canadian Journal of Education, XVII/3, 341-364. 
David, M., Alldred, P., in Smith, P. (2002). »Get Real About Sex«: Linking Sex and Relationship Education to the Achievement Agenda, Keele: Keele University.

Diorio, J. A., in Munro, J. A. (2000). Doing Harm in the Name of Protection: Menstruation as a Topic For Sex Education. Gender and Education, XII/3, 347-365.

Diorio, J. A. (2001). Sexuality, Difference, and the Ethics of Sex Education. Journal of Social Philosophy, XXXII/3, 277-300.

Dobnikar, M. (2009). Gibanje proti nasilju nad ženskami med feminizmom in socialnim delom. Dialogi, VL/11-12, 98-110.

Donald, J. (1992). Sentimental Education, London in New York: Verso.

Duffy, M., in Burtney, E. (2004). Young People and Sexual Health, New York: Palgrave.

Easton, S. M. (1994). The Problem of Pornography: Regulation and the Right to Free Speech, London in New York: Routledge.

Eisenhart, M. (2001). Educational Ethnography Past Present and Future: Ideas to Think With. Educational Researcher, XXX/8, 16-27.

Epstein, D., O'Flynn, S., in Telford, D. (2000). »Othering« Education: Sexualities, Silences and Schooling. Review of Research in Education, XXV/1, 127-179.

Fairclough, N. (2003). Analysing Discourse, New York: Routledge.

Faller Coulborn, K. (2007). Interviewing Children About Sexual Abuse: Controversies and Best Practice, Oxford in New York: Oxford University Press.

Felski, R. (2000). Doing Time. Feminist Theory and Postmodern Culture, New York in London: New York University.

Foucalt, M. (1986). Power/Knowledge: Selected Interviews and Other Writings, Gordon, C. (ur.), Brighton: The Harvester Press.

Foucault, M. (1998). Zgodovina seksualnosti 2: Uporaba ugodij, Ljubljana: Škuc. Francis, B., in Skelton, Ch. (2001) (ur.). Investigating Gender. Contemporary Perspectives in Education, Buckingham in Philadelphia: Open University Press.

Freud, S. (1987). Metapsihološki spisi, Ljubljana: Škuc in Filozofska fakulteta. Freud, S. (1995). Tri razprave o teoriji seksualnosti, Ljubljana: Škuc in Znanstveni inštitut Filozofske fakultete. 
Fuller, S. (2006). The Philosophy of Science and Technology Studies. New York in London: Routledge.

Giere, R. N. (1999). Introduction. The Science Wars in Perspective, v Science Without Laws. Chicago: University of Chicago Press, 1-8, http:// www.tc.umn.edu/ giere/SWL_intro.pdf (7.7.2010).

Gill, R. (2007). Gender and the Media, Cambridge in Malden: Polity Press. Goetz, P. J., in Grant, L. (1988). Conceptual Approaches to Studying Gender in Education. Anthropology \& Education Quarterly, IXX/2 (Women, Culture, and Education), 182-196.

Gould, S. J. (2000). Za-mera človeka, Ljubljana: Krtina.

Graff, H. J. (1995). The Labyrinths of Literacy. Reflections on Literacy Past and Present, Pittsburgh in London: University of Pittsburgh Press.

Grasswick, H. E., in Webb, M. O. (2002). Feminist Epistemology as Social Epistemology. Social Epistemology, XVI/3, 185-196.

Gray, C., in Leith, H. (2004). Perpetuating Gender Stereotypes in the Classroom: A Teacher Perspective. Educational Studies, XXX/1, 3-17.

Greif, T. (2009). Na begu pred terorjem normalizacije. Dialogi, VL/11$12,82-97$.

Grogan, S. (1998). Body Image, New York in London: Routledge.

Gunter, B. (2002). Media Sex. What Are the Issues?, Mahwah in London: Lawrence Erlbaum.

Haraway, D. (1989). Introduction: The Persistence of Vision. V: Primate Visions. Gender, Race, and Nature in the World of Modern Science, New York in London: Routledge, 1-15.

Haraway, D. (1992). Ecce Homo, Ain't (Ar'n't) I a Woman, and Inappropriate/d Others: The Human in a Post-Humanist Landscape. V: Butler, J., in Scott, J. W. (ur.). Feminist Theorize the Political, London: Routledge, 86-100.

Haraway, D. (1996). Metafore v hardwareu: Harry Harlow in tehnologija ljubezni. Delta, II/1-2, 135-154.

Haraway, D. (1997). Modest Witness@Second Millenium. FemaleMan Meets OncoMouse: Feminism and Technoscience, London in New York: Routledge.

Haraway, D. (1998). How Like a Leaf. An Interview with Thyrza Nichols Goodeve, London in New York: Routledge. 
Haraway, D. (1999). Opice, kiborgi in ženske. Reinvencija narave, Ljubljana: Študentska založba.

Harding, S. (1987) (ur.). Feminism and Methodology, Bloomington: Indiana University Press.

Harding, S. (1991). Whose Science? Whose Knowledge?: Thinking from Women's Lives, Ithaca: Cornell University Press.

Hasebrink, U., Livingstone, S., in Haddon, L. (2008). Comparing Children's Online Opportunities and Risks Across Europe: Cross-National Comparisons for EU Kids Online, London: EU Kids Online.

Hesse-Biber, Sh. N., in Yaiser, M. L. (2004) (ur.). Feminist Perspectives on Social Research, New York in Oxford: Oxford University Press.

Hite, S. (2006). The Shere Hite Reader: New and Selected Writings on Sex, Globalization and Private Life, New York, London, Toronto in South Yarra: Palgrave Macmillan.

Hubbard, R. (1988). Science, Facts, and Feminism. Hypatia, 1, 5-17.

Itzin, C. (2001a). Pornography and the Social Construction of Sexual Inequality. V: Itzin, C. (ur.). Pornography. Women, Violence and Civil Liberties, Oxford in New York: Oxford University Press, 57-75.

Itzin, C. (2001b). A Legal Definition of Pornography. V: Itzin, C. (ur.). Pornography: Women, Violence and Civil Liberties, Oxford in New York: Oxford University Press, 435-455.

Jackson, Ph. W. (1968). Life in Classrooms, New York: Holt, Rinehart and Winston.

Jackson, S. (1997). Crossing Borders and Changing Pedagogies: From Giroux and Freire to Feminist Theories of Education. Gender and Education, IX/4, 457-467.

Jameson, F. (1992). Signatures of the Visible, New York \& London: Routledge.

Jameson, F. (2001). Postmodernizem, Ljubljana: Društvo za teoretsko psihoanalizo.

Jeriček Klanšček, H., Lavtar, D., Pokrajac, T. (2007).Z zdravjem povezano vedenje v šolskem obdobju: HBSC Slovenija 2006, Ljubljana: Inštitut za varovanje zdravja Republike Slovenije.

Johnson, A., in Whitty, M. (2008). Truth, Lies and Trust on the Internet, New York in London: Routledge.

Kellogg, C., Translating Deconstruction. Cultural Values, V/3, 325-348. 
Keppeler, S. (2001). Pornography: The Representation of Power. V: Itzin, C. (ur.). Pornography. Women, Violence and Civil Liberties, Oxford in New York: Oxford University Press, 88-101.

Kimmel, M. (2007). The Sexual Self. The Construction of Sexual Scripts, Nashville: Vanderbuilt University Press.

Klein, E. R. (1993). Criticizing Feminist Critique of Objectivity. Reason Papers, 18, 57-69.

Kodelja, Z. (2003). Pravičnost v izobraževanju in šolska (ne)diferenciacija otrok po spolu. The School Field, IXX/5-6, 73-84.

Komidar, K., in Mandeljc, S. (2009). Homoseksualnost skozi analizo učnih načrtov, šolskih učbenikov in šolske prakse. Sodobna pedagogika, LX/4, 164-181.

Kreuger, R. A., in Casey, M. A. (2000). Focus Groups: A Practical Guide for Applied Research, Thousand Oaks, London in New Delhi: Sage Publications

Kuhn, T. (1998). Struktura znanstvenih revolucij, Ljubljana: Krtina.

Leach, M. (1990). Toward Writing Feminist Scholarship into History of Education. Educational Theory, XL/4, 453-462.

Lennon, K., in Whitford, M. (1994) (ur.). Knowing the Difference. Feminist Perspectives in Epistemology, London in New York: Routledge.

Lenzo, K. (1995). Validity and Self-Reflexivity Meet Postructuralism: Scientific Ethos and the Transgressive Self. Educational Researcher, maj, $17-24$.

Linker, M. (2000). Defending Feminist Territory in the Science Wars. V: Bart, J. (ur.). Women Succeeding in the Sciences. Theories and Practices Across Disciplines, West Lafayette, Indiana: Purdue University Press, 177-194.

Linker, M. (2005). When Worlds Collide: The Global Exportation of Anti-Enlightenment Scholarship. Social Theory and Practice, 3, 451-461.

Luke, A. (1988). Literacy, Textbooks and Ideology, London, New York in Philadelphia: The Falmer Press.

Luke, A. (1993). On Reading and Sexual Division of Literacy. The School Field, IV/3-4, 113-147.

Luthar, B. (2007). Mobilni telefon in pospešena kultura. Javnost-the Public, 14, S5-S18. 
MacKinnon, C. (1996). Only Words, Cambridge in Massachusetts: Harvard University Press.

McRobbie, A. (2007). Top Girls? Young Women and the Post-Feminist Sexual Contract. Cultural Studies, XXI/4-5, 718-737.

Melendez, F. (2004). Video Pornography, Visual Pleasure, and the Return of the Sublime. V: Williams, L. (ur.).Porn Studies. Durham in London: Duke University Press, 401-427.

Merrill, B. (2009). Using Biographical Methods in Social Research, London: Sage.

Mill, J. S. (1992). On Liberty and Utilitarianism, London: Oxford University Press.

Močnik, R. (1999). 3 teorije. Ideologija, nacija, institucija. Ljubljana: cf.

Moran, L., in Skeggs, B. (2004). Sexuality and the Politics of Violence and Safety, New York: Routledge.

Mulinari, D., in Sandell, K. (1999). Exploring the Notion of Experience in Feminist Thought. Acta Sociologica, XLII/287, 287-297.

Narayan, U., in Harding, S. (2000) (ur.). Decentering the Center. Philosophy for a Multicultural, Postcolonial, and Feminist World, Bloomington in Indianapolis: Indiana University Press, 110-127.

Nayak, A., in Kehily, M. J. (2008). Gender, Youth and Culture: Young Masculinities and Femininities, Houndmills in New York: Palgrave Macmillan.

Nielsen, H. B. (2004). Noisy Girls: New Subjectivities and Old Gender Discourse. Young. Nordic Yournal of Youth Research, XII/1, 9-30.

Nye, A. (2000). Strong Objectivity and the Language of Science. V: Bart, J. (ur.). Women Succeeding in the Sciences. Theories and Practices Across Disciplines, West Lafayette, Indiana: Purdue University Press, 195-203.

Pilcher, J., in Whelehan, I. (2004): Fifty Key Concepts in Gender Studies, London, Thousand Oaks, New Delhi: Sage Publications.

Pinnick, C., Koertge, N., in Almeder, R. F. (2003) (ur.). Scrutinizing Feminist Epistemology. An Examination of Gender in Science, New Brunswick, New Jersey in London: Rutgers University Press.

Prins, B. (1995). The Ethics of Hybrid Subjects: Feminist Constructivism According to Donna Haraway. Science, Technology and Human Values, 3, 352-367.

Radstone, S. (2008). Sexual Politics of Time, New York in London: Routledge. 
Ramazanoğlu, C., s Holland, J. (2002). Feminist Methodology. Challenges and Choice, Los Angeles, London, New Delhi, Singapore in Washington: Sage.

Rédai, D. (2003). Gender and Education in Slovenia and Hungary. Comparative Analysis of Slovenian and Hungarian Educational Reforms since the 1990s, magistrsko delo, Budimpešta: Central European University.

Rolin, K. (2006). The Bias Paradox in Feminist Standpoint Epistemology. Episteme. A Journal of Social Epistemology, X/1-2, 125-136.

Russell, D. E. H. (1993). Against Pornography: The Evidence of Harm, Berkeley: Russell Publications.

Russell, S. (1986). The Hidden Curriculum of School: Reproducing Gender and Class Hierarchies. V: Hamilton, R., and Barrett, M. (ur.). The Politics of Diversity: Feminism, Marxism and Nationalism, London: Verso, 343-360.

Skeggs, B. (2004). Class, Self, Culture, London: Routledge.

Skeggs, B. (2005). The Re-Branding of Class: Propertising Culture. V: Devine, F., Savage, M., in Crompton, R. (ur.), Rethinking Class: Culture, Identities \& Lifestyle, Basingstoke: Palgrave Macmillan, 46-48.

Skeggs, B., in Wood, H. (2008). Spectacular morality: »Reality« television, individualisation and the remaking of the working class. V: Hesmondhalgh D., in Toynbee, J. (ur.). The Media and Social Theory. London in New York: Routledge, 177-193.

Slapšak, S. (2001). Snappy Answers to Stupid Questions. Topos, 1-2, 35-61.

Stoetzler, M., in Yuval-Davis, N. (2002). Standpoint Theory, Situated Knowledge and the Situated Imagination. Feminist Theory, 3, 315-333.

Strehovec, J. (2007). Besedilo in novi mediji: Od tiskanih besedil $k$ digitalni besedilnosti in digitalnim literaturam, Ljubljana: Literarno-umetniško društvo Literatura.

Sullivan, Sh., in Tuana, N. (2007) (ur.). Race and Epistemologies of Ignorance, Albany: State University of New York.

Šribar, R. (2004): O menstruaciji: Telo v diskurzu, diskurz v telesu, Ljubljana: Delta.

Šribar, R. (2006). O pornografiji. Porno konstrukcija in feministična rekonstrukcija seksualnosti, Ljubljana: Sophia. 
Šribar, R. (2007). Pornografska razmerja: rekonceptualizacija »morale« in družbene večine skozi klasiko liberalizma. Casopis za kritiko znanosti, XXXV/229-230, 404-413.

Šribar, R., in Vendramin, V. (2009). Neformalne norme in konstrukcije spolov v šoli in medijih. V: Tašner, V. (ur.). Brezspopada: Kultur, spolov, generacij, Ljubljana: Pedagoška fakulteta univerze v Ljubljani, 117-128.

Tuana, N. (2006). The Speculum of Ignorance: The Women's Health Movement and Epistemologies of Ignorance. Hypatia, XXI/3, 1-19.

Ule, M. (2007). Mladi in družbene spremembe. IB rev., XLI/2, 62-69.

Ule, M. (2008). Odraščanje socialno prikrajšanih mladih. Socialna pedagogika, XII/1, 19-38.

Ule, M. (2009). Socialna psihologija: Analitični pristop k življenju in druž$b i$, Ljubljana: Fakulteta za družbene vede.

Ule, M. (2008). Za vedno mladi? Socialna psihologija odraščanja, Ljubljana: Fakulteta za družbene vede.

Vendramin, V. (2005). »Šola za deklice«: Kurikularne spremembe in enakost v izobraževanju, Ljubljana: Pedagoški inštitut.

Vendramin, V. (2009). Od kod prihajajo dejstva?: feminizem in transformacije nekaterih temeljnih epistemoloških pojmov. Dialogi, VL/11$12,57-68$.

Vendramin, V., in Šribar, R (2010). Spol v raziskovanju: od binarizma in homogenosti h kompleksnosti, Družboslovne razprave, XXVI/64: 25-43.

Walkerdine, V. (1989).The Girls and Mathematics Unit. Counting Girls Out, London: Virago.

Walkerdine, V. (1998). Popular Culture and Eroticization of Little Girls. V: Jenkins, H., The Children's Culture Reader, New York in London: New York University Press, 154-164.

Walkerdine, V., Lucey, H., in Melody, J. (2001). Growing Up Girl: Psychosocial Explorations of Gender and Class, Basingstoke: Palgrave.

Wall, D. S. (2007). Cybercrime, Cambridge: Polity Press.

Williams, L. (2004). Porn Studies: Proliferating Pornographies On/Scene: An Introduction. V: Williams, L. (ur.). Porn Studies, Durham in London: Duke University Press,1-23.

Williams, R. (1997). Navadna kultura: Izbrani spisi, Ljubljana: Studia Humanitatis.

Woolf, V. (2000). Tri gvineje, Ljubljana: Delta. 
Zillmann, D., in Bryant, J. (1989) (ur.). Pornography. Research Advances \& Policy Considerations, Hillsdale in Hove \& London: Lawrence Erlbaum.

\section{Spletne strani}

Anderson, E. How Not to Criticize Feminist Epistemology: a Review of Scrutinizing Feminist Epistemology, http://www-personal.umich. edu/ eandersn/hownotreview.html (10.7.2009).

Direktiva AVMS (Direktiva o avdiovizualnih medijskih storitvah), http:// ec.europa.eu/avpolicy/reg/tvwf/index_en.htm (18.5.2010).

Eurydice - NFER (2009). Sex and Relationship Education in Other Countries, http://www.inca.org.uk/Sex_and_relationships_education_ December_2009_.pdf(11.5.2010).

Eurobarometer (2008). Towards a safer use of the Internet for children in the EU - a parents' perspective, http://ec.europa.eu/information society/activities/sip/docs/eurobarometer/eurobarometer_2008.pdf (8.1.2009).

IPPF (2006). Sexuality Education in Europe, http://www.euro.who.int/ Document/RHP/SexEd_in_Europe.pdf (2009).

Janack, M. (2004). Feminist Epistemologies, Internet Encyclopedia of Philosophy, http://www.iep.utm.edu/fem-epis/ (18.6.2010).

Kijkwijzer (2007). Expansion of the Kijkwijzer classification system, http://www.kijkwijzer.eu/pagina.php?id=7 (20.4. 2009).

KZ 12008 (Kazenski zakonik), http://www.uradni-list.si/1/ content?id=86833 (2.3.2009).

Livingston, S., in Haddon, L. (2009). EU Kids Online: Final report, http://www.lse.ac.uk/collections/EUKidsOnline/Reports/EUKidsOnlineFinalReport.pdf (9. 6. 2010).

More trust in content: The potential of co- and self-regulation in digital media, http://www.leipzig-eu2007.de/en/index.asp (13. 1. 2009).

Sloyan, G. S. (2003). Pedophilia among the Catholic clergy: Some questions and answers. Theology Today, julij 2003, http://findarticles.com/p/ articles/mi_qa3664/is_200307/ai_n9251864/pg_8 (22.4.2009).

SRDF (Svet z radiodifuzijo) (2006). Smernice za vsebinsko oblikovanje internih etičnih in estetskih pravil (kodeksov) izdajateljev televizijskih programov smernic za njihovo vsebinsko oblikovanje, http://www. srdf.si/File/projekti/smernice.pdf (20. 4. 2009). 
UEM (2008). Spremljanje izvajanj Pekinških izhodišč za ukrepanje, http://209.85.129.132/search?q=cache:UBNokDUo0psJ:www.uem. gov.si/si/delovna_podrocja/slovensko_predsedstvo_svetu_eu_na_ podrocju_enakosti_spolov/sodelovanje_tria_predsedstev/spremljanje_izvajanja_pekinskih_izhodisc_za_ukrepanje/+uem,kazalci,dekli $\mathrm{ce} \& \mathrm{~cd}=2 \& \mathrm{hl}=\mathrm{sl} \& \mathrm{ct}=\mathrm{clnk} \& \mathrm{gl}=\mathrm{si}(22.4 .2009)$.

Vrečer, V. (ur.) (2009). Medkulturne kompetence v izobraževanju odraslih, Ljubljana: Andragoški center RS, http://arhiv.acs.si/publikacije/Medkulturne_kompetence_v_izobrazevanju_odraslih.pdf(11.5.2010).

ZMed - UPB1 2006 (Zakon o medijih), http://zakonodaja.gov.si/rpsi/ r05/predpis_ZAKO4955.html (10.4.2009).

ZVPot-UPB2 2004 (Zakon o varstvu potrošnikov), http://www.uradnilist.si/1/ulonline.jsp?urlid=200498\&dhid=71713 (20. 2. 2009). 

kazalo

A

Alcoff, L. 40, 42, 43

Ali, S. 67

Alice, L. 11

Allen, L. 64, 65, 66, 67, 83

Anderson, E. 20, 22, 26, 27, 32, 34, 35

Antić, M. G. 105

Anyon, J. 51

Apple, M. W. 74, 75

Arditti, R. 41

Ariès, Ph. 67

Arnot, M. 79

Attwood, F. 110

Austin, J. 97

B

Baer, S. 118

Bahovec, E. D. 17, 20, 23, 24, 28, 38, $39,42,44,62,63,72,79$

Bajt, M. 125

Beasley, C. 45, 90, 91, 92, 109

Beauvois, J. L. 111, 112

Benveniste, E. 97
Blair, M. 68

Boldin, M. 103

Braidotti, R. 91

Brcar, P. 125

Bregar Golobič, K. 62

Brooks, A. 11

Brown, B. 95, 108

Brunsdon, Ch. 13

Bryant, J. 13, 113

Buckingham, D. 67, 68

Bunch, Ch. 38

Butler, J. 57, 96, 97, 110, 113

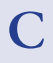

Campbell, K. 19

Casey, M. A. 54

Cealey Harrison, W. 21, 63

Check, J. 113, 114

Code, L. 42

Connel, R. 90

Connolly, P. 68

Coppock, V. 11

Currie, D. 22, 32, 79 
$\mathrm{D}$

Diorio, J. A. 59, 60, 66, 74, 75

Dobnikar, M. 59, 107

Donald, J. 74

Dreifus, C. 41

$\mathrm{E}$

Easton, S. M. 118

Eisenhart, M. 55, 56

Epstein, D. 65, 67, 68

F

Faludi, S. 11

Felman, Sh. 38, 42

Felski, R. 18, 20, 36, 37, 79

Foucault, M. 46, 94, 105, 110

Fox Keller, E. 28

Francis, B. 63

Fraser, N. 79

Freud, S. 94, 96

Fuller, S. 18, 21, 27

G

Giere, R. N. 21, 29

Gill, R. 11, 12, 13

Given, L. M. 28, 31

Goetz, J. P. 50, 51

Gorelick, Sh. 20

Gorenc, M. 125

Gould, S. J. 24, 25, 27

Graff, H. 78

Grant, L. 50, 51

Grasswick, H. E. 19, 23, 31, 44

Gray, C. 63

Greif, T. 91

Gunter, B. 113
$\mathrm{H}$

Haack, S. 26

Haddon, L. 116

Haraway, D. 17, 19, 22, 24, 25, 27, 28 , 29, 30, 31, 32, 33, 34, 35, 36, 37, 38, $41,43,44,52,53,73,76,79$

Harding, S. 17, 19, 24, 33, 35, 36, 38, 43

Harlow, H. 27, 28

Hartsock, N. 34

Hasebrink, U. 100, 111, 114, 116, 126

Hesse-Biber, Sh. N. 28, 32

Hintikka, M. B. 19

Hite, S. 97

Holland, J. 68

Hood-Williams, J. 21

Hubbard, R. 26, 28

I

Itzin, C. 95, 98

$J$

Jackson, Ph. 72

Jackson, S. 39, 78

Jaggar, A. M. 56, 57

Jameson, F. 94, 95, 96, 109

Janack, M. 18, 31

Jeriček Klanšček, H. 63, 70

Johnson, J. A. 109

K

Kant, I. 54

Kehily, M. J. 84, 86, 104, 105, 106

Kellogg, C. 56

Keppeler, S. 96, 108

King, K. 29

Klee, R. 34 
Klein, E. R. 21, 24, 35, 43

Klein, N. 11

Kodelja, Z. 63

Komidar, K. 65

Košir, M. 64

Kourany, J. 27

Krek, J. 73

Kreuger, R. A. 54

Kuhar, R. 65

Kuhn, T. 21

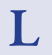

Leach, M. 62

Leith, H. 63

Lennon, K. 18

Lenzo, K. 28

Linker, M. 21, 23

Livingstone, S. 116

Longino, H. 20

Luke, A. 72, 76, 77

Luthar, B. 46, 52, 53, 87, 88

Lyotard, J.-F. 79

\section{M}

Mac an Ghaill, M. 79

MacKinnon, C. 53, 95, 96, 97

Mandeljc, S. 65

McRobbie, A. 12, 105

Melendez, F. 53, 96

Mill, J.S. 118

Močnik, R. 110

Mohanty, Ch. T. 33

Moi, T. 90

Morley, D. 13

Mulinari, D. 38

Muller, J. M. 93

Munro, J. A. 66, 74, 75

\section{N}

Narayan, U. 38

Nayak, A. 84, 86, 104, 105, 106

Nicholson, L. 79

Nielsen, H. B. 108

Nye, A. 21

$P$

Paglia, C. 11

Penley, C. 38, 39, 72, 79

Pilcher, J. 46, 88

Pinnick, C. 20, 22, 26, 27, 32, 34

Prins, B. 19, 29, 31, 36, 44

R

Ramazanoğlu, C. 17, 20, 29, 33, 36, 37,44

Ramšak, M. 54, 55, 58

Rédai, D. 65

Rolin, K. 35

Russell, D. E. H. 99

Russell, S. 62

\section{$S$}

Sacco, L. 42

Sandell, K. 38

Schaffer, S. 29

Schensul, J. J. 28

Seaman, B. 42

Shannon, M. 113

Shapin, S. 29

Sheldon, S. 68

Siraj-Blatchford, I. 68

Siraj-Blatchford, J. 68

Sirk, N. 56

Skeggs, B. 104, 106

Skelton, Ch. 63 
Slapšak, S. 98

Sloyan, G. S. 114

Sokal, A. 18

Stoetzler, M. 19, 32, 33, 34

Stone-Mediatore, Sh. 38

Strehovec, J. 46, 53, 86, 88, 89, 95

Sullivan, Sh. 40, 42, 43



Šribar, R. 14, 40, 59, 61, 68, 70, 85, 90, $99,103,106,114,118,119,120,127$

$\mathrm{T}$

The Boston Women's Health Col-

lective 41

Thorne, B. 68

Thorogood, N. 66

Tuana, N. 40, 41, 42, 43

U

Ule, M. 63, 68, 70, 92, 112, 120, 127

V

Vannini, Ph. 31

Vendramin, V. 23, 63, 65, 90, 105, 114

Verčkovnik, T. 75

Vrdlovec, Z. 99

Vrečer, N. 71

\section{W}

Walkerdine, V. 49, 62, 68, 84, 105, 106

Wall, D. S. 53, 113, 119

Webb, M. O. 19, 23, 31, 44

Weinberg, S. 27

Whelehan, I. 11, 46, 88

Whitford, M. 18

Whitty, M. 109
Zillmann, D. 13, 113

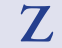

$\check{\mathrm{Z}}$

Žižek, S. 93, 112, 113
Wicke, J. 11

Williams, L. 147

Williams, R. 14, 94, 108, 147

Wood, H. 106

Woolf, V. 23, 24, 43

Y

Yaiser, M. L. 28, 32

Yuval-Davis, N. 19, 32, 33, 34 



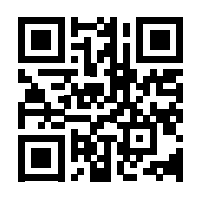

